\title{
Desenvolvimento do Processo de Produção e Estudo Estrutural e Magnético de Filmes Finos Ordenados de FePt
}

\section{Alessandro Martins}

INSTITUTO DE FISICA

Serviço de Biblioteca e Informaçao

Tombo: 4016
Banca examinadora:
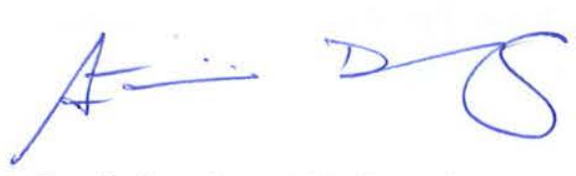

Prof. Dr. Antonio Domingues dos Santos (IFUSP)

(orientador)

Prof. Dra. Helena Maria Petrilli (IFUSP)

Prof. Dra. Aline Yvette Ramos (LNLS)

Prof. Dr. João Edgar Schmidt (UFRGS)

Prof. Dr. Luiz Carlos Sampaio Lima (CBPF)

São Paulo 2004
Tese apresentada ao Instituto de Física da Universidade de São Paulo como parte dos requisitos para a obtenção do título de Doutor em Ciências.

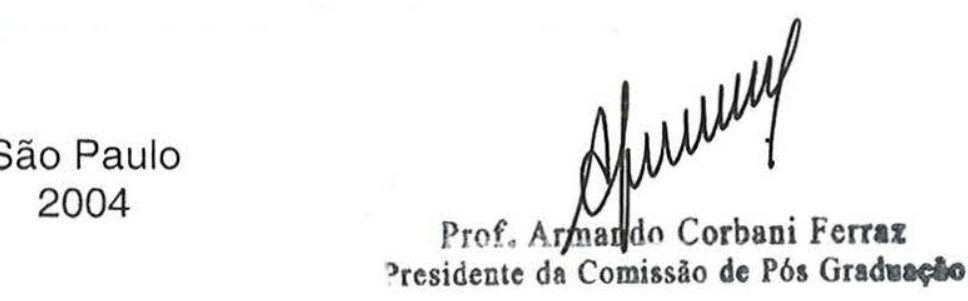




\section{FICHA CATALOGRÁFICA \\ Preparada pelo Serviço de Biblioteca e Informação do Instituto de Física da Universidade de São Paulo}

Martins, Alessandro

Desenvolvimento do Processo de Produção e Estudo Estrutural e Magnético de Filmes Finos Ordenados de FePt. São Paulo, 2004.

Tese (Doutoramento) Universidade de São Paulo Instituto de Física - Depto. de Física dos Materiais e Mecânica

Orientador: Prof. Dr. Antonio Domingues dos Santos Área de Concentração: Física

Unitermos:

1. Filmes Finos Magnéticos;

2. Sputtering;

3. Estrutura Cristalina e Textura;

4. Anisotropia Magnética;

5. Gravação Magnética.

USP/IF/SBI-024/2004

SBI-IFUSP

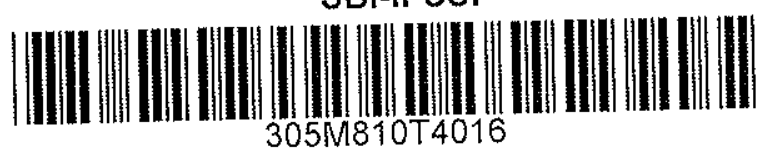


"No meio de qualquer dificuldade encontra-se a oportunidade." Albert Einstein

À minha mãe e minha querida Silvana como gratidão pelo que fizeram por mim. 


\section{Agradecimentos}

Ao professor Antonio Domingues dos Santos pela orientação, paciência, dedicação e estímulo na realização deste trabalho.

À professora Márcia C. de Abreu Fantini, pela oportunidade de trabalho no Laboratório de Cristalografia (LCr) do Instituto de Física da Universidade de São Paulo (IFUSP), onde realizei as medidas de Difração de Raios-X (XRD), pelos ensinamentos recebidos sobre a técnica de XRD e Espectroscopia de Absorção de Raios-X que tanto contribuíram para a realização deste trabalho. Muito obrigado pela atenção que sempre dedicou a mim.

Aos meus pais, minha querida Silvana e meus irmãos pelo apoio em todas as ocasiões.

Ao Professor Manfredo H. Tabacniks pelas discussões sobre a técnica de RBS.

Aos amigos Tamura e Narcizo do Laboratório Nacional de Luz Síncrotron (LNLS) pelo auxílio nas medidas de XAS.

Ao amigo Rogério J. Prado pelo grande auxílio com as simulações de XANES e EXAFS.

À professora Ivette F. C. Oppenheim pelos ensinamentos recebidos sobre os mecanismos de formação de filmes finos.

Aos professores do Laboratório de Materiais Magnéticos (LMM) do IFUSP pelos seus ensinamentos e coleguismo.

Aos funcionários do IFUSP pelo auxílio na obtenção de recursos materiais, no manuseio dos equipamentos e na aquisição dos dados experimentais, a citar:

- Laboratório de Materiais Magnéticos: Iran, Sérgio, Marcelo, Renato, Marcos, Paulo e Alexandre

- Laboratório de Cristalografia: Antônio Carlos

- Laboratório de Análises de Materiais por Feixes Iônicos: Marcos, Marcel e Marcus Vinícius

Aos colegas do IFUSP pela grande amizade. Não cito nomes, pois, não gostaria de cometer a injustiça de me esquecer de algum deles.

A todos os amigos, de modo geral, pelo grande auxílio nas horas difíceis.

À FAPESP pelo apoio financeiro à realização deste trabalho.

Em especial a Deus por esta oportunidade. 


\section{Tabelas}

Tabela 4.1: Parâmetros experimentais utilizados na obtenção dos espectros de XAS dos filmes de FePt.

Tabela 5.1: Filmes finos de FePt depositados sobre substratos de $\mathrm{SiO}_{2}, \mathrm{Si}(100) \mathrm{e}$ $\mathrm{MgO}(100)$.

Tabela 5.2: Filmes finos de $\mathrm{FePt}$ depositados sobre substratos de $\mathrm{SiO}_{2}, \mathrm{Si}(100)$ e $\mathrm{MgO}(100)$, com uma camada "buffer" de Pt.

Tabela 5.3: Propriedades estruturais e magnéticas dos filmes de FePt depositados sobre substratos de $\mathrm{SiO}_{2}, \mathrm{Si}(100)$ e $\mathrm{MgO}(100)$.

Tabela 5.4: Filmes de platina $(\mathrm{Pt})$ depositados sobre substratos de $\mathrm{SiO}_{2}, \mathrm{Si}(100)$ e $\mathrm{MgO}(100)$.

Tabela 5.5: Propriedades estruturais e magnéticas dos filmes de FePt/Pt depositados sobre substratos de $\mathrm{SiO}_{2}, \mathrm{Si}(100)$ e $\mathrm{MgO}(100)$.

Tabela 5.6: Filmes de Platina (Pt) sobre substratos de $\mathrm{MgO}(100)$.

Tabela 5.7: Valores de tamanho médio do grão cristalino $\left(D_{h k l}\right)$, parâmetro de ordenamento químico de longo alcance de $(S)$ e campo coercivo perpendicular $\left(H_{C \perp}\right)$, para os filmes de FePt que apresentam a fase FCT $(001)$.

Tabela 5.8: Valores de tamanho médio do grão cristalino $\left(D_{h k l}\right)$, parâmetro de ordenamento químico de longo alcance $(S)$ e campo coercivo perpendicular $\left(H_{C l}\right)$, para os filmes de FePt que apresentam a fase estrutural FCT(001).

Tabela 5.9: Características das amostras analisadas por XAS.

Tabela 5.10:Parâmetros estruturais obtidos com os ajustes teóricos de EXAFS da amostra FCC, FCT1 e FCT2. 


\section{Figuras}

Fig. 1.1: Evolução da densidade superficial de armazenamento de mídias magnéticas Comerciais.

Fig. 1.2: Diagrama esquemático de um sistema de gravação magnética convencional. 4

Fig. 1.3: Diagrama esquemático de um sistema (protótipo) de gravação magnética perpendicular.

Fig. 1.4: Diagrama esquemático do processo de gravação e leitura magnetoóptica.

Fig. 2.1: Desenho esquemático de um filme fino.

Fig. 2.2: Estágios de crescimento de um filme. (a) nucleação, (b) crescimento, (c) coalescência dos núcleos, (d) preenchimento dos canais e formação do filme contínuo.

Fig. 2.3: Estruturas cristalinas.(a) estrutura tipo Al (FCC) (b) estrutura tipo L $1_{0}$ (FCT). 20

Fig. 3.1: Esquema simplificado de um sistema de "sputtering".

Fig. 3.2: Sistema de "sputtering magnetron" utilizado para a preparação das amostras.

Fig. 3.3: Configuração interna da câmara principal durante o método de (a) codeposição (os dois "shutters" abertos simultaneamente) e (b) DAM (os "shutters" de cada "gun" são abertos em sequiência, permitindo a vazão de material e a respectiva deposição de camada por camada de cada elemento).

Fig. 3.4: Imagem do porta substrato usado na produção das amostras.

Fig. 4.1: Arranjo experimental simplificado de RBS. Na Figura, temos que $\theta$ é o ângulo de espalhamento, $\psi$ o ângulo entre o feixe incidente e o feixe retroespalhado e $\Omega$ o ângulo sólido do detector.

Fig. 4.2: Espectro de RBS de um filme fino de $\mathrm{Fe}_{0.51} \mathrm{Pt}_{0.49}$ e espessura $104 \mathrm{~nm}$ depositado sobre um substrato de $\mathrm{Si}(100)$.

Fig. 4.3: Difratogramas de raios-X de pó de uma liga $\mathrm{Fe}_{0.5} \mathrm{Pt}_{\mathrm{t}_{0.5}}$ : (a) estrutura desordenada FCC; (b) estrutura ordenada FCT.

Fig. 4.4: Ilustração do processo de emissão da radiação síncroton.

Fig. 4.5: Diagrama esquemático da absorção de raios- $X$ por um átomo isolado.

Fig. 4.6: Diagrama esquemático da absorção de raios- $X$ em meios condensados. 
Fig. 4.7: Espectros de XAS característicos para (a) átomos isolados e (b) embutido em uma fase condensada. Note-se o aparecimento de oscilações após a borda de absorção no caso em que o átomo está em uma fase conciensada. Em (c), uma representação esquemática mostrando que as oscilações são devido ao processo de interação do fotoelétron criado durante o processo de absorção (representado como uma onda esférica que sai do absorvedor) com a estrutura de ordem local. Essa onda é refletida pelos átomos espalhadores, retornando ao átomo absorvedor e interferindo com a onda inicial.

Fig. 4.8: Resumo do processo de extração de dados de EXAFS. (a) Espectro de absorção de um filme de FePt. (b) Oscilações de EXAFS extraídas de (a). (c) Transformada de Fourier das oscilações presentes em (b). (d) Oscilações de EXAFS correspondentes apenas a primeira esfera de vizinhos, obtidas através de uma transformada inversa de Fourier da região definida em (c).

Fig. 4.9: Configuração utilizada para medidas de XAS em função da polarização do vetor campo elétrico $(\mathbf{E})$.

Fig. 4.10: Diagrama esquemático de um VSM.

Fig. 4.11: Típica curva de histerese.

Fig. 5.1: (a) Difratogramas de XRD e (b) curvas de histerese de filmes de FePt depositados sobre substratos de $\mathrm{SiO}_{2}$.

Fig. 5.2: Gráficos com (a) valores de tamanho médio do grão cristalino $\left(D_{h k l}\right)$, correspondente ao plano de difração FePt(111), e (b) valores de campo coercivo $\left(\mathrm{H}_{\mathrm{C}}\right)$, em função da temperatura de deposição $\left(\mathrm{T}_{\mathrm{S}}\right)$, dos filmes finos de FePt depositados sobre substratos de $\mathrm{SiO}_{2}$.

Fig. 5.3: (a) Difratogramas de XRD e (b) curvas de histerese de filmes de FePt depositados sobre substratos de $\mathrm{Si}(100)$.

Fig. 5.4: Gráficos com (a) valores médios de tamanho de grão cristalino $\left(\mathrm{D}_{\mathrm{hkl}}\right)$, correspondente ao plano de difração FePt(111), e (b) valores de campo coercivo $\left(\mathrm{H}_{\mathrm{C}}\right)$, em função da temperatura de deposição $\left(\mathrm{T}_{\mathrm{S}}\right)$, dos fílmes finos de FePt depositados sobre substratos de $\mathrm{Si}(100)$.

Fig. 5.5: (a) Difratogramas de XRD e (b) curvas de histerese de filmes de FePt depositados sobre substratos de $\mathrm{MgO}(100)$.

Fig. 5.6: (a) Difratogramas de XRD e (b) curvas de histerese de filmes de FePt/Pt depositados sobre substratos de $\mathrm{SiO}_{2}$.

Fig. 5.7: Gráficos com valores de (a) área integrada $\left(I_{h k l}\right)$, (b) tamanho médio do grão cristalino $\left(D_{h k l}\right)$, e (c) campo coercivo $\left(\mathrm{H}_{\mathrm{C}}\right)$, em função da temperatura do substrato $\left(\mathrm{T}_{\mathrm{S}}\right.$ ), dos filmes de $\mathrm{FePt} / \mathrm{Pt}$ depositados sobre substratos de $\mathrm{SiO}_{2}$. 
Fig. 5.8: Superposição de difratogramas de XRD de filmes de Pt depositados sobre $\mathrm{SiO}_{2}$.

Fig. 5.9: (a) Difratogramas de XRD e (b) curvas de histerese de filmes de FePt/Pt depositados sobre substratos de $\mathrm{Si}(100)$.

Fig. 5.10: Espectros de RBS e respectiva simulação para filmes de FePt/Pt depositados sobre $\mathrm{Si}(100)$. (a) Amostra preparada em $\mathrm{T}_{\mathrm{S}}=300^{\circ} \mathrm{C}$, onde se verifica baixíssimo efeito de interdifusão atômica. (b) Amostra preparada em $\mathrm{T}_{\mathrm{S}}=500^{\circ} \mathrm{C}$, onde se verifica grande efeito de interdifusão atômica (ver Círculo pontilhado).

Fig. 5.11: Superposição de difratogramas de XRD de filmes de Pt depositados sobre $\mathrm{Si}(100)$.

Fig. 5.12: (a) Difratogramas de XRD e (b) curvas de histerese de filmes de FePt/Pt depositados sobre substratos de $\mathrm{MgO}(100)$,

Fig. 5.13: Superposição de difratogramas de XRD de filmes de Pt depositados sobre $\mathrm{MgO}(100)$.

Fig. 5.14: Difratogramas de XRD de filmes de Pt depositados sobre substratos de $\mathrm{MgO}(100)$, em variados valores de $\mathrm{T}_{\mathrm{S}}$, com espessuras de (a) $2 \mathrm{~nm} \mathrm{e}$ (b) $\sim 22 \mathrm{~nm}$.

Fig. 5.15: Difratogramas de XRD de filmes de Pt depositados sobre substratos de $\mathrm{MgO}(100)$, em variados valores de $\mathrm{T}_{\mathrm{S}}$, com espessuras de (a) $\sim 51 \mathrm{~nm}$ e (b) $\sim 80 \mathrm{~nm}$.

Fig. 5.16: Diagrama esquemático com a sequência de deposição utilizada para a preparação de amostras de $\mathrm{FePt} / \mathrm{Pt} / \mathrm{MgO}$. Em cada etapa, primeiramente depositamos o "buffer" de Pt sobre o MgO nas temperaturas I ndicadas. Em seguida, depositamos, sobre os "buffers", a camada de FePt na respectiva temperatura indicada.

Fig. 5.17: Difratogramas de XRD e curvas de histerese de filmes de FePt depositados em $\mathrm{T}_{\mathrm{S}}=200^{\circ} \mathrm{C}$ sobre um "buffer" de Pt pré-depositado sobre substratos de $\mathrm{MgO}(100) \mathrm{em}$ (a) $\mathrm{T}_{\mathrm{S}}=200^{\circ} \mathrm{C}$, (b) $\mathrm{T}_{\mathrm{S}}=300^{\circ} \mathrm{C}$ e (c) $\mathrm{T}_{\mathrm{S}}=500^{\circ} \mathrm{C}$.

Fig. 5.18: Difratogramas de XRD e curvas de histerese de filmes de FePt depositados em $\mathrm{T}_{\mathrm{S}}=300^{\circ} \mathrm{C}$ sobre um "buffer" de Pt pré-depositado sobre substratos de $\mathrm{MgO}(100)$ em (a) $\mathrm{T}_{S}=200^{\circ} \mathrm{C}$, (b) $\mathrm{T}_{\mathrm{S}}=300^{\circ} \mathrm{C}$ e (c) $\mathrm{T}_{\mathrm{S}}=500^{\circ} \mathrm{C}$.

Fig. 5.19: Difratogramas de XRD e curvas de histerese de filmes de FePt depositados em $\mathrm{T}_{\mathrm{S}}=500^{\circ} \mathrm{C}$ sobre um "buffer" de Pt pré-depositado sobre substratos de $\mathrm{MgO}(100)$ em (a) $\mathrm{T}_{\mathrm{S}}=200^{\circ} \mathrm{C}$, (b) $\mathrm{T}_{\mathrm{S}}=300^{\circ} \mathrm{C}$ e (c) $\mathrm{T}_{\mathrm{S}}=500^{\circ} \mathrm{C}$. 
Fig. 5.20: Espectros de RBS e respectiva simulações para filmes de FePt/Pt. (a)Amostra com pequeno efeito de interdifusão atômica entre camada FePt e o "buffer" de Pt. (b) Amostra preparada em $\mathrm{T}_{\mathrm{S}}(\mathrm{Pt} \mathrm{LFePt})=200 \backslash 500^{\circ} \mathrm{C}$ com grande efeito de interdifusão atômica entre as camadas (ver círculo pontilhado).

Fig. 5.21: Curvas de histerese (medidas na geometria perpendicular ao plano do filme) de amostras que possuem uma fase estrutural predominate FePt FCT(001) (alto grau de ordenamento químico) e cujas as camadas FePt possuem espessuras diferentes.

Fig. 5.22: Espectros de RBS, com respectivas simulações, e difratogramas de XRD para filmes de $\mathrm{FePt}$ crescidos sobre $\mathrm{Pt} / \mathrm{MgO}(100)$, em pressões de deposição de (a)2, (b) 5 e (c) 10 mTorr.

Fig. 5.23: (a) Difratogramas de XRD e (b)curvas de histerese obtidas para filmes de FePt crescidos por DAM sobre substratos de $\mathrm{MgO}(100)$.

Fig. 5.24: (a) Difratogramas de XRD e (b) curvas de histerese obtidas para filmes de FePt crescidos por DAM sobre substratos de Pt/MgO(100), de acordo com o procedimento 1 .

Fig. 5.25: (a) Difratogramas de XRD e (b) curvas de histerese obtidas para filmes de FePt crescidos por DAM s obre substratos de $\mathrm{Pt} / \mathrm{MgO}(100)$, de acordo com o procedimento 2 .

Fig. 5.26: Difratogramas de XRD de filmes de FePt crescidos por DAM sobre substratos de (a) $\mathrm{SiO}_{2}$ e (b) $\mathrm{Pt} / \mathrm{SiO}_{2}$.

Fig. 5.27: (a) Superposição de espectros de XANES obtidos através de simulações teóricas para vários tipos de estruturas. (b) Superposição de espectros de XANES da amostra FCC e da estrutura $\mathrm{Fe}_{3} \mathrm{Pt}$.

Fig. 5.28: (a) Superposição de espectros de XANES, obtidos através de simulações teóricas para uma estrutura tipo L1o (FCT), com a polarização do campo $\mathbf{E}$ variando de uma direção no plano $\left(\theta=0^{\circ}\right)$ ate uma condição perpendicular ao plano do filme $\left(\theta=90^{\circ}\right)$. Em (b) e (c), superposição de espectros de XANES das amostras (b)FCT1 e (c) FCT2, obtidos sobre valores de $\theta$ de $15^{\circ}, 36^{\circ}$ e $75^{\circ} .98$

Fig. 5.29: Transformadas de Fourier do espectro experimental de EXAFS das amostras analisadas por XAS. Medidas obtidas com o ângulo $(\theta)$ entre a radiação incidente e a normal ao plano do filme fixado em $36^{\circ}$.

Fig. 5.30: Superposição de transformadas de Fourier do espectro de EXAFS da amostra FCT1, obtidos através de medidas de XAS com o ângulo $(\theta)$ entre a radiação incidente e a normal ao plano do filme fixado em $15^{\circ}, 36^{\circ}$ e $75^{\circ}$.

Fig. 5.31: (a) TF do espectro experimental de EXAFS da amostra FCC (obtido na configuração $\theta=36^{\circ}$ ) sobreposto à TF obtida através de uma simulação para uma estrutura teórica $\mathrm{Fe}_{3} \mathrm{Pt}$ (FCC). (b) $\mathrm{TF}$ da estrutura $\mathrm{Fe}_{3} \mathrm{Pt}$ ajustada ao valor experimental da amostra $\mathrm{FCC}$. 
Fig. 5.32: (a) TF do espectro experimental de EXAFS da amostra FCC (obtido na configuração $\theta=36^{\circ}$ ) sobreposto à TF obtida através de uma simulação para uma estrutura teórica (a) $\mathrm{Fe}_{3} \mathrm{Pt}$ e (b) $\mathrm{FePt}_{3}$.

Fig. 5.33: (a) TF do espectro experimental de EXAFS das amostras FCT1 e FCT2 (obtido na configuração $\theta=36^{\circ}$ ) sobreposto à TF obtida através de uma simulação para uma estrutura teórica FePt (FCT). (b) TF da estrutura FePt (FCT) ajustada ao valor experimental das amostras FCT1 e FCT2. 


\section{Abreviaturas}

CGS

DAM

$D_{h k l}$

EBE

EXAFS

FCC

FCT

$H_{C / /}$

$H_{C \perp}$

JCPDS

MOKE

MEK

MBE

MFM

$P_{S}$

RBS

$S$

$\mathbf{T}_{\mathrm{S}}$

TF

UHV

VSM

XRD

XAS

XANES
Sistema Gaussiano de Unidades

Deposição Alternada de Monocamadas

Tamanho médio do grão cristalino referente à orientação $\{h k 1\}$

Evaporação por Canhão de Elétrons (Electron-Beam Evaporation)

Estrutura Fina Estendida de Absorção de Raios-X (Extended X-ray

Absorption Fine Structure).

Estrutura Cúbica de Face Centrada (Face-Centered Cubic)

Estrutura Tetragonal de Face Centrada (Face-Centered Tetragonal)

Campo coercivo medido na geometria no plano do filme

Campo coercivo medido na geometria perpendicular ao plano do filme

(Joint Committee on Powder Diffraction Standards)

Efeito Kerr Magnetoóptico (Magneto-Optic Kerr Effect)

Magnetometria de Efeito Kerr

Epitaxia de Feixe Molecular (Molecular Beam Epitaxy)

Microscopia de Força Magnética (Magnetic Force Microscopy)

Potência de "sputtering"

Espectroscopia de Retroespalhamento Rutherford (Rutherford

Backscattering Spectroscopy)

Parâmetro de ordenamento químico de longo alcance

Temperatura do substrato.

Transformada de Fourier

Ultra-Alto Vácuo (Ultra High Vacuum)

Magnetometria de Amostra Vibrante (Vibrating Sample Magnetometer)

Difração de Raios-X (X-Ray Diffraction)

Espectroscopia de Absorção de Raios-X (X-ray Absorption Spectroscopy)

Estrutura Próxima a Borda de Absorção (X-ray Absorption Near Edge Structure) 


\section{Índice}

CAPÍTULO 1: Introdução

CAPÍTULO 2: Filmes Finos Magnéticos $\quad 10$

2.1 Mecanismos de Formação da Microestrutura 12

$\begin{array}{ll}2.2 \text { Propriedades Magnéticas } & 15\end{array}$

2.3 Filmes Finos de FePt 19

CAPÍTULO 3: Técnica de Preparação $\quad 22$

3.1 A Técnica de Sputtering 23

3.2 O Sistema de Sputtering Utilizado $\quad 25$

3.2.1 Características da Produção das Amostras 28

CAPÍTULO 4: Técnicas de Caracterização 31

4.1 Espectroscopia de Retroespalhamento Rutherford (RBS) 32

4.1.1 Sistema Utilizado e Procedimentos Experimentais 35

4.2 Difração de Raios-X (XRD) 36

4.2.1 Sistema Utilizado e Procedimentos Experimentais $\quad 40$

4.3 Espectroscopia de Absorção de Raios-X (XAS) 41

4.3.1 Radiação Síncrotron $\quad 42$

4.3.2 Absorção de Raios-X 43

4.3.3 Sistema Utilizado e Procedimentos Experimentais 48

4.4 Magnetometria de Amostra Vibrante (VSM) 50

4.4.1 Sistema Utilizado e Procedimentos Experimentais 52

CAPÍTULO 5: Resultados Experimentais e Discussões 53

5.1 Descrição dos Filmes Produzidos

5.2 Filmes Preparados pelo Método de Codeposição 56

5.2.1 Filmes de FePt depositados diretamente sobre o substrato 56

5.2.2 Filmes de FePt depositados sobre um "buffer" de Pt 64

5.2.3 Filmes de FePt depositados sobre um "buffer" de Pt otimizado 74

5.3 Filmes Preparados pelo Método de Deposição Alternada de Monocamadas
(DAM)

5.4 Medidas de XAS em Filmes de FePt 95

5.4.1 Análises de XANES 96

5.4.2 Análises de EXAFS 98

Capítulo 6: Conclusões 105

6.1 Filmes de FePt preparados por Codeposição 106

$\begin{array}{ll}6.2 \text { Filmes de FePt preparados por DAM } & 107\end{array}$

$\begin{array}{ll}\text { Capítulo 7: Sugestões para Trabalhos Futuros } & 109\end{array}$

Apêndice I: Fichas JCPDS 111 
Apêndice II: Publicações em Períodicos

Apêndice III: Trabalhos apresentados em eventos

Referências Bibliográficas 


\section{Resumo}

Filmes de ligas FePt com uma estrutura quimicamente ordenada Tetragonal de Face Centrada FCT (tipo L1 $1_{0}$ ) e textura [001] apresentam anisotropia magnética perpendicular, alta coercividade e grande efeito Kerr Polar magnetoóptico. Entretanto, filmes completamente ordenados são normalmente obtidos através de um processo de "sputtering" com deposições em altas temperaturas do substrato $\left(\mathrm{T}_{S} \geq 600^{\circ} \mathrm{C}\right)$ ou por pós-tratamento térmico em temperaturas maiores que $500^{\circ} \mathrm{C}$. As pesquisas atualmente em desenvolvimento visam a obtenção dessa estrutura ordenada a temperaturas mais baixas, o que seria mais adequado para aplicações práticas dos filmes.

Neste trabalho, procuramos as melhores condições para a preparação de filmes de FePt com a fase ordenada FCT(001) em reduzidas temperaturas. Investigamos a influência do método de deposição, temperatura do substrato, espessura do filme e tipo de substrato sobre o grau de ordem química e textura dos filmes de FePt e, conseqüientemente, sobre suas propriedades magnéticas.

Os filmes finos de ligas $\mathrm{Fe}_{x} \mathrm{Pt}_{1-x}(\operatorname{com} \mathrm{x} \approx 50$ at\%) foram preparados por " Sputtering Magnetron DC", através de dois diferentes métodos de deposição: pelo método usual de codeposição e pelo método de deposição alternada monocamadas atômicas (DAM). Os filmes foram crescidos sobre substratos de $\mathrm{SiO}_{2} / \mathrm{Si}(100)$, $\mathrm{Si}(100)$ e $\mathrm{MgO}(100)$, com e sem uma camada "buffer" de Pt (com espessuras de 50 a $76 \mathrm{~nm}$ ), sob $\mathrm{T}_{\mathrm{S}}$ variando de temperatura ambiente a $600^{\circ} \mathrm{C}$. O "buffer" de Pt foi usado para permitir melhores condições para a indução de um crescimento "epitaxial" da ordenada fase FCT(001) nos filmes de FePt.

Os resultados da caracterização estrutural e magnética realizados através das técnicas de Difração de Raios-X (XRD) e Magnetometria de Amostra Vibrante (VSM) mostram que os substratos de $\mathrm{MgO}$ são adequados para induzir um crescimento "epitaxial" de filmes de FePt com uma estrutura FCT e textura [001]. Entretanto, com o uso de um "buffer" de Pt otimizado (com predominante fase $\mathrm{FCC}(100)$ ), pré-depositado sobre $\mathrm{MgO}$, foram obtidos melhores resultados em termos de "epitaxia" conveniente para o ordenamento da estrutura cristalina, para os filmes de FePt preparados por ambos os métodos de deposição. Os resultados mostram também que o efeito de um crescimento "epitaxial" induzido varia com a espessura do filme. Em relação ao método de deposição, os resultados revelam a maior eficiência do método DAM em comparação com o método de codeposição para a preparação de filmes de FePt com a fase FCT $(001)$, em temperaturas reduzidas $\left(\mathrm{T}_{S} \leq 400^{\circ} \mathrm{C}\right)$. Com o uso do método DAM, foi possível a obtenção da fase ordenada $\mathrm{FCT}(001)$ em filmes de $\mathrm{FePt}$ crescidos diretamente sobre $\mathrm{o} \mathrm{MgO}$ em $\mathrm{T}_{\mathrm{S}}=400^{\circ} \mathrm{C}$. Para filmes de FePt crescidos sobre $\mathrm{Pt} / \mathrm{MgO}$, a formação da fase $\mathrm{FCT}(001)$ foi verificada em $\mathrm{T}_{S}=200^{\circ} \mathrm{C}$ e um alto grau de ordenamento químico $(S=0,88) \mathrm{em}_{\mathrm{S}}=400^{\circ} \mathrm{C}$. Estudos de Espectroscopia de Absorção de Raios-X (XAS) também foram realizados. 


\section{Abstract}

FePt alloy films, with a chemically ordered face-centered-tetragonal FCT (type $\mathrm{L}_{0}$ ) structure and [001] texture, present perpendicular magnetic anisotropy, high coercivity and large polar magneto-optical Kerr effect. However, completely ordered films are usually obtained either by sputtering process at high substrate temperatures $\left(\mathrm{T}_{S} \geq 600^{\circ} \mathrm{C}\right)$ or by postannealing treatment at temperatures higher than $500^{\circ} \mathrm{C}$. For technological purposes the preparation temperature has to be as low as possible.

In this work we have searched the more adequate conditions to preparation of $\mathrm{FePt}$ films with ordered $\mathrm{FCT}(001)$ phase at reduced temperatures. We have investigated the influence of deposition methods, substrate temperature, thickness of the film, and type of substrate on the degree of the chemical ordering and preferred texture of FePt films and, consequently, on their magnetic properties.

The $\mathrm{Fe}_{\mathrm{x}} \mathrm{Pt}_{1-\mathrm{x}}$ alloy thin films (with $\mathrm{x} \approx 50$ at $\%$ ) were prepared by DC Magnetron Sputtering, via two different deposition methods: a conventional codeposition method and an alternate monatomic layer (DAM) deposition method. The films were grown on $\mathrm{SiO}_{2} / \mathrm{Si}(100)$, $\mathrm{Si}(100)$ and $\mathrm{MgO}(100)$ substrates, with and without a Pt buffer layer (thickness ranging from 50 to $76 \mathrm{~nm}$ ), at $\mathrm{T}_{\mathrm{S}}$ varying from room temperature to $600^{\circ} \mathrm{C}$. The Pt buffer layer was used for obtaining better conditions to the induction of an epitaxial grown of $\mathrm{FePt}$ films with the ordered FCT $(001)$ phase.

The results of structural and magnetic characterization performed by X-ray diffraction (XRD) and vibrating sample magnetometry (VSM) show that the MgO substrates are adequate to induce an epitaxial growth of FePt films with a FCT structure and [001] texture. However, with the use of an optimized Pt FCC(100) buffer layer pre-deposited on $\mathrm{MgO}$, the best conditions to an epitaxial induced growth were obtained, by both deposition methods. The results show also that the quality of the epitaxial induced growth depends on the thickness of the film. In relation to the deposition method, the results reveal the higher efficiency of the alternate monatomic layer deposition method in comparison to the codeposition method for preparation of FePt FCT(001) films, at reduced temperatures $\left(\mathrm{T}_{S} \leq\right.$ $400^{\circ} \mathrm{C}$ ). With the use of the DAM method it was possible to obtain the ordered FCT $(001)$ phase in the FePt film grown directly on $\mathrm{MgO}$, at $\mathrm{T}_{S}=400^{\circ} \mathrm{C}$. For FePt film grown on $\mathrm{Pt} / \mathrm{MgO}$, the formation of the $\mathrm{FCT}(001)$ phase was verified at $\mathrm{T}_{\mathrm{S}}=200^{\circ} \mathrm{C}$, and a high degree of chemical order $(S=0,88)$ was obtained at $\mathrm{T}_{S}=400^{\circ} \mathrm{C}$. X-ray Absorption Spectroscopy (XAS) studies also were done. 


\section{CAPÍTULO 1}

\section{Introdução}

Como uma introdução ao nosso trabalho, apresentamos neste capítulo uma breve revisão histórica sobre o processo de gravação magnética, as perspectivas de evolução desta área tecnológica e os meios que poderão ser utilizados para viabilizar esta evolução. Dentro deste contexto, apresentamos a nossa motivação pelo estudo de filmes de FePt, bem como, as suas potencialidades científicas e tecnológicas. 
Nas últimas décadas, a gravação magnética se tornou a mais importante ferramenta utilizada no processo de armazenamento de dados. Uma das principais vantagens da gravação magnética é que a informação armazenada pode ser modificada em algum momento ou simplesmente substituída por outra informação.

Devido ao enorme mercado que depende da tecnologia de armazenamento de dados, tem se buscado o desenvolvimento de novas tecnologias que, juntamente com novos materiais, possibilitem aumentar a densidade de informações magneticamente armazenadas. As pesquisas atualmente visam transpor os obstáculos que impedem tal objetivo.

O uso de materiais magnéticos para a gravação de informações iniciou-se apenas em 1898, quando o engenheiro dinamarquês Valdemar Poulsen conseguiu gravar e reproduzir sinais de áudio em um fio de aço magnetizável [1]. Em 1927, o químico austríaco Fritz Pfleumer conseguiu revestir fitas de papel com partículas de aço. Anos mais tarde, em 1932, as empresas de tecnologia Eletric Company AEG e a I.G. Farben (conhecida nos dias atuais como BASF) conseguiram desenvolver fitas de plástico revestidas com partículas de óxidos de ferro, o que levou em 1935 à invenção do "Magnetofone", dispositivo considerado o antecessor dos modernos gravadores magnéticos. Na década de 50 grandes atividades de pesquisas em eletrônica e magnetismo levaram ao desenvolvimento do disco rígido "HD"1 (IBM "RAMAC" - 1956), desenvolvido para armazenar, magneticamente, dados em computadores. O "RAMAC" era formado por discos de alumínio revestidos, em ambos os lados, por uma camada de partículas de $\gamma-\mathrm{Fe}_{2} \mathrm{O}_{3}$ [2]. Em 1963 foi introduzido pela Philips na Holanda o "Compact Audiocassete", formado por fitas revestidas com partículus de dióxido de cromo. No ano de 1971 foi desenvolvido o "Disquete", formado por um fíno material plástico coberto também com partículas de $\gamma-\mathrm{Fe}_{2} \mathrm{O}_{3}$, fabricado primeiramente em formato de 8 polegadas, mais tarde em 5,25 e em 3,5 polegadas [1].

A partir de 1970, o desenvolvimento de ligas policristalinas baseadas em cobalto, níquel, cromo e ferro, mediante a utilização de diversas técnicas de deposição ou crescimento, permitiu a fabricação de filmes magnéticos para serem usados como mídias para gravação magnética (digital), implicando em um dos maiores avanços nas aplicações de materiais magnéticos. A partir de 1980 inicia-se a utilização de dados codificados magneticamente em cartões de crédito, bilhetes de sistemas de transporte, cartões de acesso, etc.

Nos tempos atuais, a crescente necessidade de se armazenar, magneticamente, informações em regiões cada vez menores na mídia (um importante meio de aumentar a

\footnotetext{
' Abreviação em inglês para o termo Hard Disk
} 


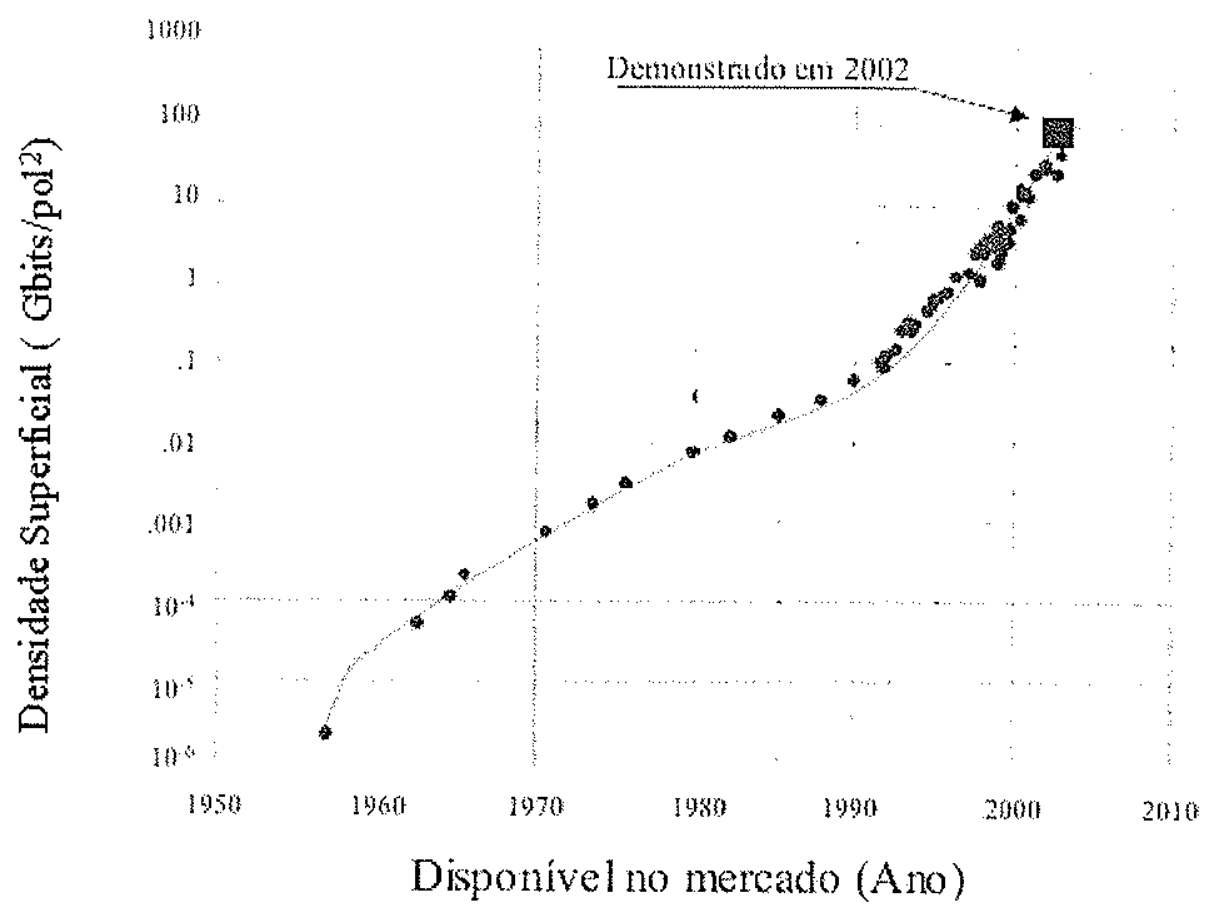

Fig.1.1 - Evolução da densidade superficial de armazenamento de mídias magnéticas comerciais.

densidade de armazenamento) têm levado a um aumento na quantidade de estudos que visam o desenvolvimento de novos materiais. Até o ano de 1998, muitos imaginavam que o limite de informações possíveis de serem armazenadas em uma mídia magnética não excederia 30 Gbits/pol ${ }^{2}[3]$. Atualmente ninguém mais se arrisca a fazcr uma previsão apesar de todos concordarem que este limite existe. No momento da elaboração deste trabalho, têm sido demonstrado [4] a possibilidade de armazenamento de dados em mídias magnéticas com densidades de $100 \mathrm{Gbits} / \mathrm{pol}^{2}$, capacidade superior a usada atualmente em mídias magnéticas comerciais $\left(60 \mathrm{Gbits} / \mathrm{pol}^{2}\right)$. Vale lembrar que a capacidade de armazenamento do primeiro disco rígido não excedia $2 \mathrm{kbits} / \mathrm{pol}^{2}$. Na Figura 1.1 é mostrado uma gráfico com a evolução da densidade superficial de armazenamento magnético até os dias atuais. Para uma melhor compreensão dos meios que poderão ser utilizados para transpor os obstáculos que impedem a possibilidade de aumento da densidade de informações armazenadas em uma mídia magnética, primeiramente se faz necessário uma descrição básica do processo convencional de gravação e leitura magnética atualmente utilizado.

O processo de gravação magnética convencional é muito simples. Basicamente, o movimento de uma mídia magnética, com uma certa velocidade, através de um cabeçote de gravação, gera a formação de um padrão de magnetização remanente na respectiva mídia [5]. 


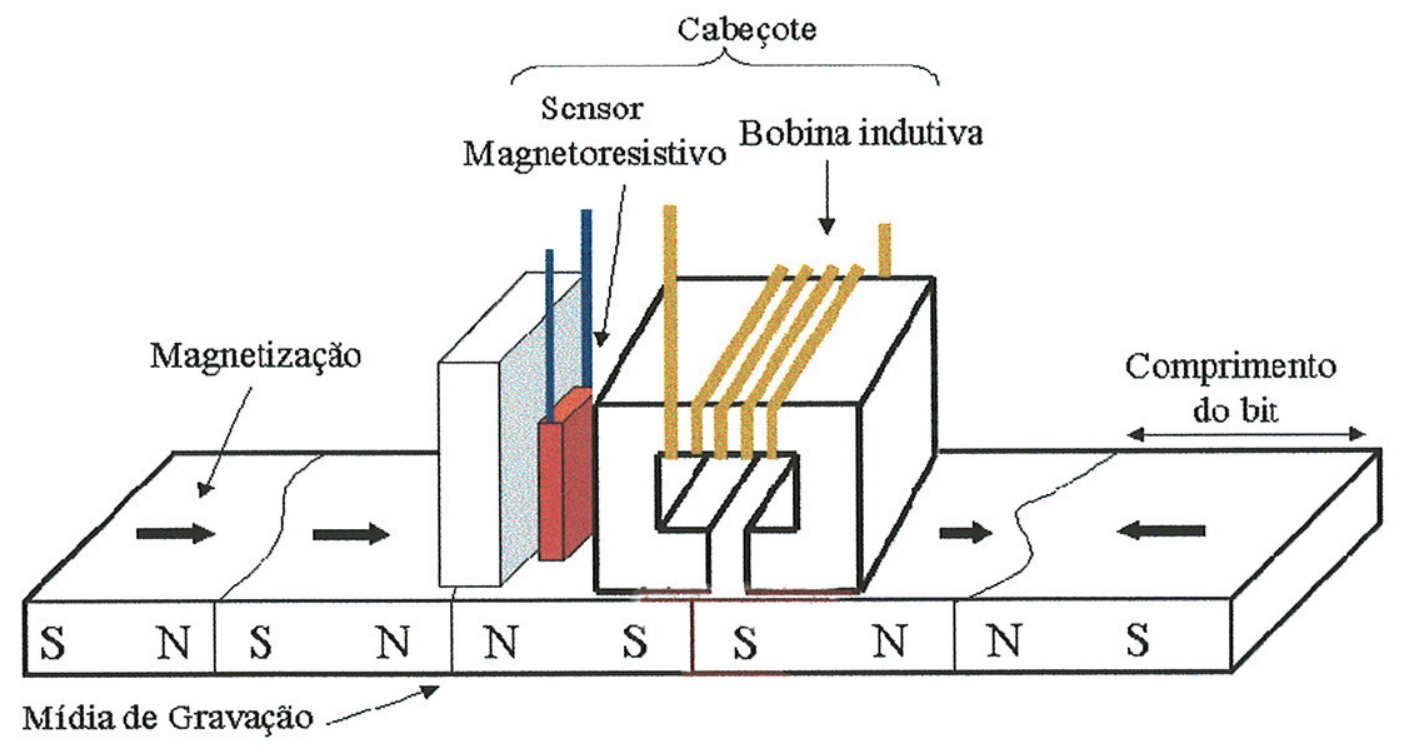

Fig. 1.2 - Diagrama esquemático de um sistema de gravação magnética convencional.

Durante muitos anos têm se utilizado cabeçotes de gravação que operam no modo 'indutivo' e que nada mais são do que uma minúsculo anel magnético na qual está enrolada uma bobina. Durante o processo de gravação, os dados a serem armazenados são convertidos em pulsos de corrente elétrica. Ao passar pela bobina, a corrente elétrica gerada induz um campo magnético suficientemente forte ('campo de escrita') para magnetizar uma pequena região da mídia. Durante muitos anos utilizou-se do mesmo 'cabeçote indutivo' para a leitura de dados. Ao movimentar a mídia sobre a cabeça metálica, a variação do campo magnético provocada por sua passagem induzirá na mesma bobina uma corrente elétrica de baixa intensidade, porém suficientemente forte para ser detectada. Com o intuito de aumentar a sensibilidade do sistema de leitura, a partir de 1990 um novo dispositivo foi introduzido no cabeçote de gravação: trata-se do sensores magnetoresistivos que operam baseados no fenômeno da magnetoresistência (maiores considerações sobre este fenômeno são encontrados no Capítulo 2). A Figura 1.2 mostra um diagrama esquemático de um sistema de gravação magnética utilizado atualmente com os elementos básicos: a bobina indutiva utilizada para a geração do 'campo de escrita' e o sensor magnetoresistivo utilizado na leitura dos dados.

Durante muitos anos, utilizou-se do processo de gravação magnética analógico, onde a própria informação é gravada diretamente na mídia. No momento, tem sido largamente 
utilizado o processo de gravação magnética digital, onde a informação a ser armazenada é "cifrada" num código de dígitos 0 e 1, através de um conversor analógico-digital. Este tipo de recurso permite que a informação seja armazenada com uma maior qualidade (alta fidelidade e perfeito grau de reprodução).

Dependendo da anisotropia magnética ${ }^{2}$ da mídia, as informações podem ser armazenadas no modo longitudinal, onde os domínios magnéticos estão dispostos paralelamente ao plano da mídia, ou no modo perpendicular, onde os domínios estão dispostos perpendicularmente ao plano da mídia. Atualmente, o método convencional de gravação magnética ainda utiliza da tecnologia de gravação longitudinal (ver Fig. 1.2).

O tamanho observado para os bits individuais é tipicamente maior que o tamanho dos grãos cristalinos constituintes da mídia [6], o que leva a acreditar que a gravação magnética resulta de maneira predominante de um fenômeno cooperativo mediado por interações entre os grãos cristalinos da mídia. As mídias magnéticas atualmente utilizadas pela tecnologia de gravação magnética longitudinal consistem de um filme fino formado por uma liga de CoPtCrX $(\mathrm{X}=\mathrm{B}, \mathrm{Ta})$ constituídos por grãos cristalinos ferromagnéticos. Em filmes finos verifica-se a presença de uma densidade de empacotamento dos grãos maior do que se obtinha com as mídias de particulados [6]. Portanto, a diminuição do tamanho dos grãos e a minimização de interações intergranulares são requisitos básicos para o aumento da capacidade de armazenamento. Porém, a diminuição do tamanho dos grãos para valores abaixo de um certo 'diâmetro crítico' provoca o surgimento de um efeito conhecido como Superparamagnetismo. Em partículas e/ou grãos com comportamento supcrparamagnético, a magnetização pode flutuar por excitação térmica. Isto ocasiona sérios problemas ao processo de gravação magnética, pois a instabilidade da magnetização dos grãos devido a flutuações térmicas pode ocasionar a perda dos dados armazenados. Uma possibilidade de superar este problema é a utilização de mídias magnéticas com anisotropia muito alta, o que possibilitaria reduzir o tamanho dos grãos sem se preocupar com o limite superparamagnético. Porém, o aumento na energia de anisotropia produz o aumento da coercividade da mídia ${ }^{2}$. Para o armazenamento de um 'bit' o cabeçote de gravação têm que gerar uma 'campo de escrita' maior do que a coercividade da mídia. Portanto, a utilização de mídias com alta anisotropia torna necessário a otimização dos sistemas de gravação/leitura de dados. Podese verificar que maiores avanços no campo da gravação magnética não serão possíveis somente com a tecnologia atual. Dentre as novas tecnologias que permitirão maiores avanços

2 O conceito de anisotropia magnética e coercividade será apresentado no Capítulo 2. 


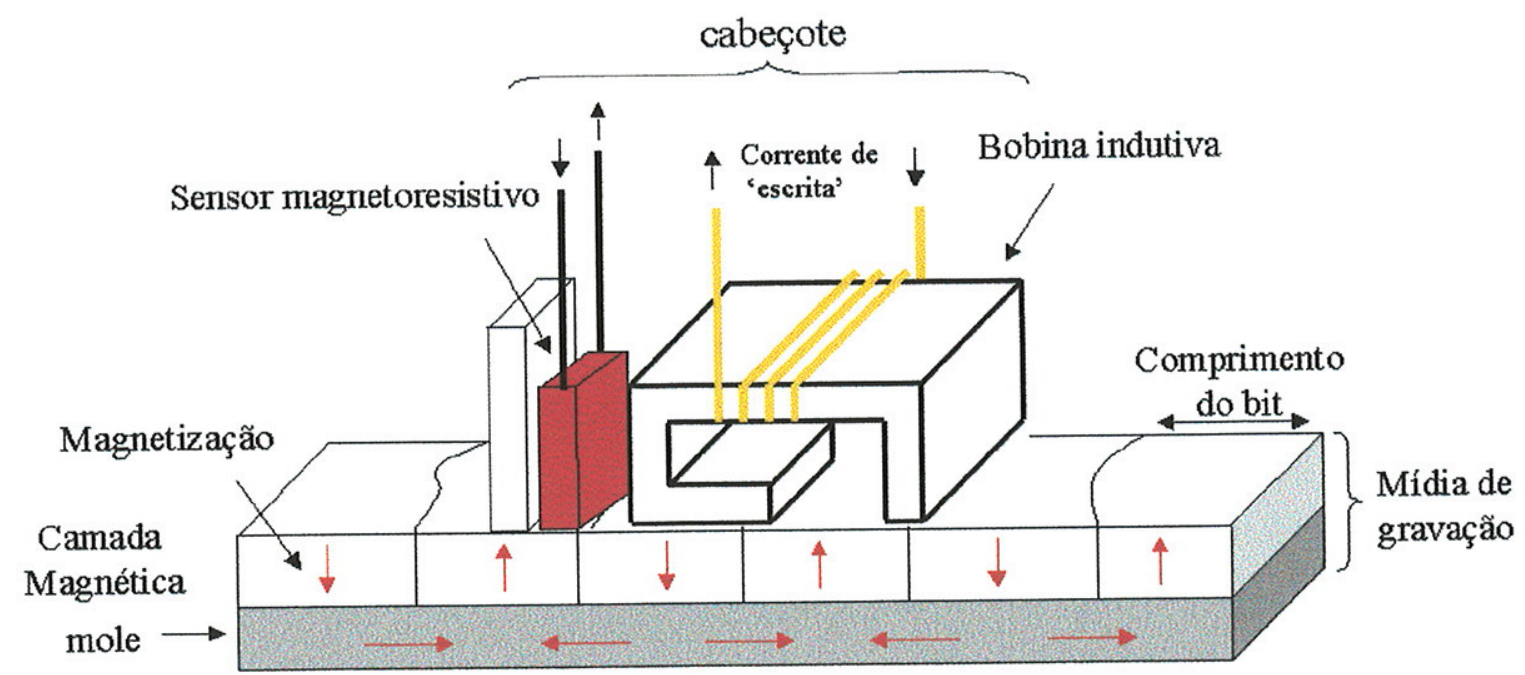

Fig. 1.3 - Diagrama esquemático de um sistema (protótipo) de gravação magnética perpendicular.

na área de gravação magnética citamos: a gravação magnética perpendicular [7] e a gravação/leitura magnetoóptica [8].

$\mathrm{Na}$ tecnologia de gravação magnética perpendicular os bits são gravados perpendicularmente ao plano do filme magnético. Para a utilização desta tecnologia são necessárias mídias magnéticas onde a orientação cristalográfica e a estrutura de grãos produzem uma forte anisotropia uniaxial perpendicular à superficie da mídia. Sua vantagem em relação à gravação magnética longitudinal é que a configuração dos bits favorece a redução dos campos desmagnetizantes existentes entre regiões adjacentes e magnetizadas em sentidos opostas, favorecendo assim a obtenção de alta densidade de gravação. Para a utilização da gravação magnética perpendicular algumas modificações tecnológicas serão necessárias pois os respectivos processos de gravação e leitura das mídias e o processamento do sinal eletrônico são diferentes do método convencional atualmente utilizado. Um diagrama esquemático de um sistema de gravação magnética perpendicular que poderá ser utilizado é apresentado na Figura 1.3. Neste esquema, pode se ver que a mídia de gravação é formada por uma camada de um filme com alta anisotropia uniaxial perpendicular depositada sobre uma camada (uma "underlayer") de um material magnético "mole', de alta permeabilidade magnética e alta magnetização de saturação [7]. A interação do campo magnético gerado pelo cabeçote de gravação com a "underlayer" possibilita um aumento da densidade de fluxo magnético através da mídia. A utilização deste recurso visa a otimização do processo de

\footnotetext{
${ }^{3}$ Materiais com grandes valores de coercividade são conhecidos como magneticamente duros ('hard') e com pequenos valores de coercividade como magneticamente moles ('soft').
} 
geração de um 'campo de escrita' com uma intensidade suficiente para magnetizar uma pequena região de uma mídia com alta anisotropia.

Por outro lado, na tecnologia magnetoóptica, a gravação é feita termomagneticamente e para leitura se utiliza os efeitos magnetoópticos Kerr polar e Faraday. Nesta tecnologia, existe também a necessidade de se trabalhar com mídias que apresentam anisotropia magnética perpendicular à superfície. O processo de gravação consiste inicialmente na focalização de um feixe de laser de alta potência sobre uma região da mídia, o qual provoca o seu aquecimento a valores próximos à Temperatura de Curie, onde a coercividade do material é baixa. Simultaneamente, é aplicado um campo magnético suficiente para alterar apenas o sentido de magnetização da região aquecida pelo laser (ver esquema na Fig. 1.4). O campo magnético é aplicado no sentido correspondente ao sinal desejado, sendo que, uma seqüência adequada de transições magnéticas definem a informação gravada. A largura do feixe de laser define a região correspondente a uma unidade básica de informação. Quando o feixe de laser é retirado, a região da mídia volta ao equilíbrio térmico e sua coercividade aumenta, mantendo fixo o domínio magnético que representa a informação armazenada. O processo de deteç̧ão (leitura de dados) envolve à adição de elementos de polarização da luz. Basicamente, um feixe de laser polarizado e de baixa potência incide sobre a superfície da mídia, na região específica que contém a informação armazenada. A luz refletida é coletada por um fotodiodo e convertida em sinal elétrico. A polarização da luz detectada varia de acordo com o sentido da magnetização da região excitada pelo laser ("Efeito Kerr"). Porém, na tecnologia magnetoóptica, a densidade de dados armazenados é basicamente limitada pelas leis de difração óptica. O tamanho mínimo de um domínio possível de ser detectado é correlacionado com o limite de resolução de Rayleigh, ou seja:

$$
d_{\min }=\frac{0,66 \lambda}{N A}
$$

onde $\lambda$ é o comprimento de onda do laser e NA é a abertura numérica de lente objetiva. Através da equação 1.1 verifica-se o interesse em se trabalhar com menores comprimentos de onda e grandes aberturas numéricas. O limite de difração luminosa para os diodos laser (vermelhos) disponíveis, projetam uma densidade de até $3.8 \mathrm{Gbits} / \mathrm{pol}^{2}$, o que é bem inferior ao atualmente obtido com a tecnologia de gravação magnética convencional (longitudinal). Mesmo com o desenvolvimento de laseres semicondutores azuis (menor comprimento de onda), a perspectiva é que se obtenha densidades de armazenamento de $\sim 15 \mathrm{Gbits} / \mathrm{pol}^{2}$. Uma alternativa que permitirá novos avanços nesta área é o desenvolvimento de um novo e 


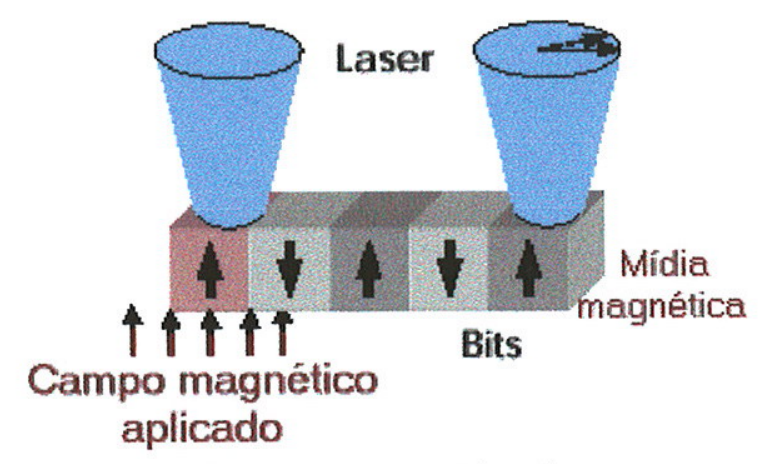

Fig. 1.4- Diagrama esquemático do processo de gravação e leitura magnetoóptica.

complexo método denominado de Gravação Magnetoóptica em Campo Próximo ou ("NearField Magneto-Optical Recording"). Em um sistema de Gravação Magnetoóptica em Campo Próximo, a distância entre a unidade de leitura de dados e a mídia é menor que o comprimento de onda da luz utilizada, numa região conhecida como 'campo próximo'. A interação entre a unidade de leitura e a mídia se dá através de ondas luminosas evanescentes (não propagativas). Esta característica permitirá a detecção de sinais magnetoópticos em pequenas regiões na mídia, possibilitando o alcance de densidades maiores que as obtidas atualmente [8].

Uma classe de filmes finos magnéticos, que apresenta anisotropia magnética perpendicular e efeitos Kerr pronunciados e que é considerado como uma possível alternativa para mídia de gravação magnética perpendicular e magnetoóptica a comprimentos de onda mais curtos é constituída por filmes cristalinos de FePt, CoPt e composições ternárias de CoFePt [9-12].

O objetivo deste trabalho é a otimização do processo de produção de filmes finos policristalinos de ligas de $\mathrm{FePt}$, com concentrações atômicas iguais de Ferro (Fe) e Platina (Pt), e a respectiva caracterização estrutural e magnética dos mesmos. Muitas das propriedades magnéticas desses filmes (anisotropia magnética perpendicular, grande coercividade e alto sinal Kerr Polar magnetoóptico) dependem fortemente do tipo de estrutura cristalina, textura e grau de ordenamento químico da amostra. Trabalhamos no desenvolvimento de novos métodos de deposição de amostras, usando a técnica de preparação "Sputtering Magnetron DC", visando obter melhores condições para a preparação de filmes de FePt com uma desejada fase tetragonal FCT(001), com alto grau de ordenamento químico. Estudamos os efeitos do método de deposição, da temperatura do substrato $\left(\mathrm{T}_{\mathbb{S}}\right)$ usada durante a deposição, tipo de substrato e espessura da amostra, na obtenção das desejadas propriedades estruturais e magnéticas para esses materiais. 
Dividimos a apresentação desta tese em 6 partes: na primeira parte fazemos uma breve introdução sobre a técnica de gravação magnética. Na segunda parte descrevemos as propriedades gerais de filmes finos magnéticos, dando ênfase aos filmes finos de FePt. Na terceira parte, apresentamos, de forma detalhada, os procedimentos experimentais utilizados para a preparação das amostras estudadas. Na quarta parte, apresentamos as técnicas de caracterização utilizadas e na quinta parte, finalmente, os resultados experimentais obtidos com o estudo desenvolvido. As discussões dos resultados experimentais são apresentadas simultaneamente à apresentação dos mesmos. Por fim, são apresentadas as conclusões do trabalho e algumas sugestões para trabalhos futuros.

Gostaríamos de salientar que o desenvolvimento deste trabalho tornou-se também possível graças a importante cooperação de outros pesquisadores como a Dra Márcia C. de Abreu Fantini (Laboratório de Cristalografia do Instituto de Física da USP - IFUSP), Dr. Manfredo H. Tabacniks (Laboratório de Análise de Materiais por Feixes Iônicos do IFUSP) e o Dr. Rogério Junqueira Prado (Departamento de Física da Universidade Federal de Santa Maria - RS). 


\section{CAPÍTULO 2}

\section{Filmes Finos Magnéticos}

Neste capítulo apresentamos uma breve descrição das propriedades estruturais e magnéticas de filmes finos magnéticos. Fazemos uma rápida abordagem dos processos de formação da microestrutura do filme, durante o respectivo processo de crescimento. Uma discussão sobre os fatores que podem influenciar na formação da respectiva microestrutura também é mostrada. Concluímos com uma apresentação das características específicas dos filmes de FePt. 
Os filmes finos são corpos sólidos cujas propriedades químicas e físicas dependem da respectiva microestrutura dos mesmos (grau de ordenamento químico, textura, diâmetro médio dos grãos, rugosidade de superfície e/ou interface, etc.). São depositados com forma bidimensional sobre a superfície de um substrato (cristalino ou amorfo) através de processos físicos ou químicos (ver Fig. 2.1). O substrato pode ou não influenciar a microestrutura do filme. Possuem diversas vantagens sobre outros materiais: sua composição e suas propriedades podem ser controladas, além de melhoradas em determinadas aplicações.

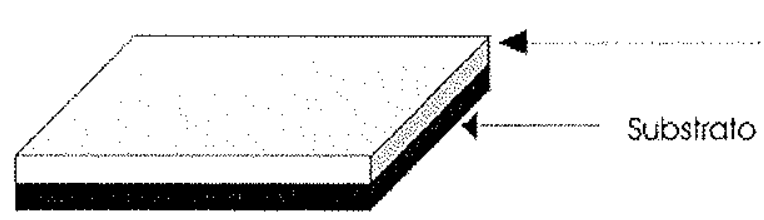

Camada formada pelo material depositado

Fig. 2.1 - Desenho esquemático de um filme fino.

A história nos mostra que a fabricação dessas finas estruturas é bem antiga. Na Antiguiidade os Egípcios produziam folhas de ouro de diversas espessuras usadas em ornamentações duráveis, com boa proteção, devido à sua resistência à degradação química [13]. Atualmente, as pesquisas em filmes finos têm sido consideradas como um dos mais importantes campos da área de ciência de materiais. Têm permitido aplicações tecnológicas na indústria de revestimentos, microeletrônica, comunicações, supercondutores, armazenamento de dados, etc. $\mathrm{Na}$ área de armazenamento de dados, especificamente para processos de armazenamento no modo magnético digital e magnetoóptico, a crescente necessidade de se armazenar informações em regiões cada vez menores na mídia têm levado ao desenvolvimento de novos filmes finos com propriedades magnéticas adequadas à respectiva aplicação, cuja estrutura é formada pela combinação de diferentes tipos de elementos químicos. De acordo com o objetivo deste trabalho, estaremos restringindo nossas discussões sobre as propriedades de filmes finos magnéticos.

Os filmes finos magnéticos são basicamente constituídos por alguns dos elementos químicos conhecidos como metais de transição $3 \mathrm{~d}$ ( $\mathrm{Fe}, \mathrm{Ni}, \mathrm{Co}, \mathrm{Mn}$ por exemplo) ou de terras raras $4 \mathrm{f}(\mathrm{Nd}, \mathrm{Sm}, \mathrm{Eu}, \mathrm{Gd}$, entre outros), os quais podem se apresentar de forma pura ou misturados com outros elementos formando ligas ou compostos. Quanto a sua forma, podem ser constituídos de uma única camada de um material magnético (filme simples) ou por camadas alternadas de materiais magnéticos e não magnéticos (fillmes multicamadas). 
Existe uma ampla variedade de técnicas de preparação de filmes finos magnéticos. Elas podem ser classificadas de acordo com o modo de deposição [13]:

a) Modo de Deposição Química - dependem de uma reação química específica de espécies convenientes na superfície do substrato. Ex.: "Deposição Eletroquúmica"

b) Modo de Deposição Física - dependem da evaporação, sublimação ou ejeção de átomos ou moléculas de um alvo. Ex.: "Evaporação Resistiva", "Evaporação por Canhão de Elétrons" (EBE), "Epitaxia por Feixe Molecular" (MBE) e "Sputtering".

Os processos de preparação geralmente realizam-se em atmosferas rarefeitas.

O estudo dos filmes magnéticos revela a existência de variadas propriedades estruturais e magnéticas. As propriedades magnéticas são influenciadas pelas propriedades estruturais, que da mesma forma são altamente dependentes do processo de formação da microestrutura do filme. A compreensão do desenvolvimento microestrutural de filmes finos é um problema complexo e que fortemente depende do conhecimento das características do processo de crescimento.

\subsection{Mecanismos de Formação da Microestrutura}

Em geral, o processo de crescimento de um filme fino depende, dentre outros fatores, do modo de deposição utilizado na preparação. Na literatura [13] é descrito que o processo de crescimento é governado por quatro estágios: (1) nucleação, (2) crescimento e coalescência dos núcleos, (3) preenchimento dos canais e formação do filme contínuo e (4) aumenio da espessura do filme com contínua deposição de material (ver Fig. 2.2). O processo de nucleação ocorre a partir da condensação (solidificação) de átomos ou moléculas da fase de vapor $^{1}$ sobre a superfície do substrato, o qual gera a formação de pequenos aglomerados de material, denominados núcleos, espalhados de maneira aleatória. Durante o processo, forças de atração eletrostáticas são as responsáveis pela fixação dos átomos à superfície. $O$ mecanismo de fixação é denominado de adsorção, o qual pode ser de natureza química e física. Os átomos adsorvidos migram sobre a superfície do substrato interagindo com os outros átomos para formar os núcleos. O aumento na quantidade de átomos que interagem provoca o crescimento desses núcleos os quais passam a ser chamados de ilhas. Quando as ilhas entram em contato umas com as outras ocorre a coalescência que resulta em estruturas maiores. O processo continua preenchendo os canais até a formação de um filme contínuo.

\footnotetext{
${ }^{1}$ Os filmes são frequientemente crescidos termicamente ou depositados a partir dá fase vapor.
} 


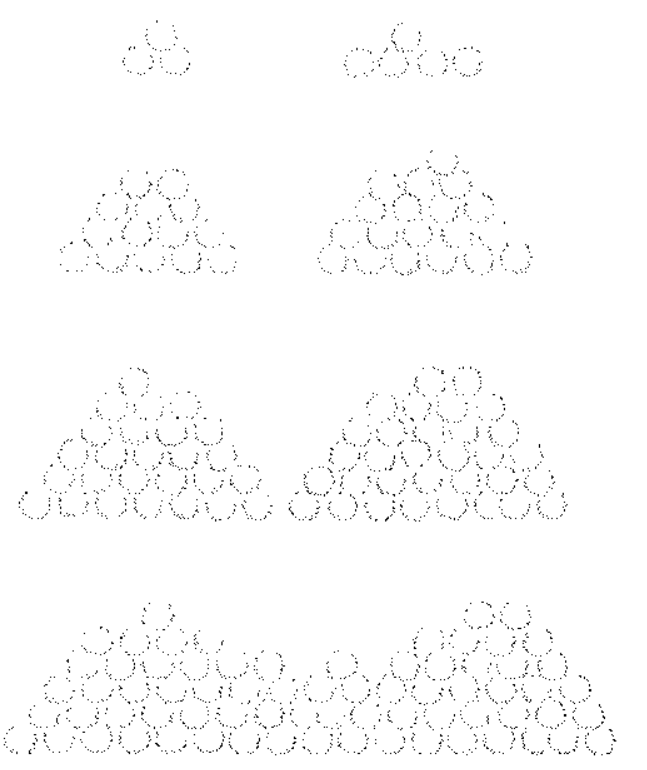

a)

b)

c)

Fig. 2.2 - Estágios de crescimento de um filme. (a) nucleação, (b) crescimento, (c) coalescência dos núcleos, (d) preenchimento dos canais e formação do filme contínuo.

d)

Durante o crescimento pode-se desenvolver uma fase amorfa (apenas ordenamento químico de curto alcance) ou cristalina ${ }^{2}$ no fillme (com ordenamento químico de curto e longo alcance). A capacidade de formação de uma fase cristalina pode depender da mobilidade atômica dos átomos sobre a superfície. O grau de mobilidade está associado, principalmente, à temperatura de deposição ${ }^{3}$ do filme. Baixas temperaturas de deposição podem decrescer a mobilidade atômica sobre a superfície e causar a deposição de um filme com uma fase amorfa, ao contrário do que acontece em altas temperaturas onde geralmente se obtém filmes cristalinos.

Em filmes cristalinos, uma vez que a continuidade do filme é atingida, verifica-se, com o seguimento da deposição de material e o respectivo aumento da espessura, o desenvolvimento de uma estrutura granular. O tamanho dos grãos cristalinos depende das condições de deposição (temperatura, pressão, etc.). É importante citar que a rugosidade de superfície do filme está diretamente relacionada com o tamanho dos grãos. Normalmente, deposições em alta temperatura tendem a produzir grãos maiores e consequentemente filmes menos rugosos. Se o filme possui grãos cristalinos com mesma estrutura cristalina e orientação cristalográfica, ele é denominado de um filme monocristalino. Quando o filme

\footnotetext{
${ }^{2}$ Nos materiais cristalinos, os átomos são arranjados de forma periódica formando o que se chama de uma rede. O arranjo periódico é definido pela espécie atômica, pelo número de coordenação (primeiros vizinhos), pela distância e ângulo de ligação de cada átomo em relação ao seus primeiros vizinhos. Cada arranjo periódico produz um plano cristalino que é caracterizado pela direção relativa a outros planos. Desse modo um conjunto de planos cristalinos formam uma característica estrutura cristalina do material.

Todos os cristais podem ser descritos em termos de 7 sistemas cristalinos, compostos por 14 redes, as chamadas "Redes de Bravais"[15]. Cada uma dessas redes possui um conjunto característico de planos cristalinos. Como os cristais possuem formas geométricas bem definidas é possível adotar-se eixos coordenados de forma a especificar a orientação cristalográfica do material.

${ }^{3}$ O termo temperatura de deposição é frequientemente substituído por temperatura do substrato $\left(\mathrm{T}_{\mathrm{S}}\right)$ na tecnologia de preparação de filmes finos magnéticos, pois geralmente sobre o substrato é que são ap̧licados as variações térmicas utilizadas nos processos de deposição.
} 
possui grãos com diferentes orientações cristalográficas ele é denominado de um filme policristalino. Nos casos onde a maioria dos grãos estão orientados em uma direção comum, temos a presença de uma orientação cristalográfica preferencial no filme. Este preferencial alinhamento é normalmente conhecido como textura cristalográfica. O fato de possuírem pequenos grãos cristalinos (da ordem de 0,01 e $1,0 \mu \mathrm{m}$ ), tornam os filmes finos mais reativos do que os materiais massivos.

Além da temperatura de deposição, outros fatores influenciam a formação da microestrutura do filme, dentre as quais citamos:

- Composição - muitos filmes finos são formados pela combinação de duas ou mais espécies atômicas. Como o arranjo atômico é dependente do número e do tamanho das espécies atômicas que interagem para formar o sólido, é normalmente verificado que o tipo de composição pode gerar uma estrutura cristalina definida no filme ou, em outros casos, até mesmo uma fase amorfa;

- Impurezas - ao serem incorporados ao material, as impurezas atômicas frequientemente causam mudanças no arranjo atômico do filme, modificando a estrutura cristalina, pois atuam como átomos intersticiais ou substitucionais. Na maioria dos casos, as impurezas são originárias de gases residuais presentes na câmara de deposição;

- Natureza do substrato - a orientação cristalográfica dos grãos cristalinos pode ser induzida pelo substrato, caso este seja cristalino, através de uma "epitaxia" granular. A epitaxia é o fenômeno no qual um fílme fino cresce com sua estrutura cristalina correlacionada com a do substrato. Normalmente, o efeito do crescimento "epitaxial" $\mathrm{em}$ um filme fino abrange poucas camadas atômicas monocristalinas crescidas sobre a superfície de um monocristal. É governado pela compatibilidade estrutural (constante de rede e estrutura cristalina) e compatibilidade química entre filme e substrato. Depende do modo de deposição, da taxa de deposição, da energia da partícula depositada e da contaminação de superfície. No caso de um substrato amorfo, a orientação dos grãos pode ser aleatória ou corresponder à orientação cristalográfica que minimiza a energia livre total do sistema. E, neste caso, ela corresponde ao plano de maior empacotamento atômico. Por empacotamento atômico compreende-se o fato de um material se tornar mais estável energeticamente se os átomos constituintes forem arranjados de uma forma mais compacta e as distâncias interatômicas forem reduzidas;

- Defeitos Estruturais - a presença de defeitos estruturais em filmes fïnos provocam uma quebra da regularidade geométrica da rede numa escala macroscópica. Tais defeitos podem gerar mudanças tanto na orientação cristalina, quanto na sequiência de 
empilhamento dos planos atômicos. Os tipo de defeitos estruturais mais comuns em filmes finos são as imperfeições planares. As imperfeições planares decorrem de uma variação no empilhamento dos planos atômicos através de um contorno. São classificados como imperfeições planares os seguintes tipos de defeitos: (i) Contornos de grão, presentes em materiais policristalinos, são regiões entre grãos cristalinos onde o empilhamento atômico é imperfeito, (ii) Contornos de macla, imperfeições superficiais que separam duas orientações que são imagens especulares uma da outra, e (iii) Falhas de empilhamento, imperfeição superficial que resulta do empilhamento de um plano atômico fora da seqüência, enquanto que a rede é perfeita de cada lado do defeito. Tais defeitos podem ser formados durante o processo de crescimento ou serem gerados após a formação do filme por agitação térmica (tratamento térmico), implantação iônica ou pela aplicação de uma tensão externa.

Uma característica importante dos filmes finos magnéticos é o fato de se encontrarem tensionados internamente, mesmo na ausência de forças externas. Estas tensões resultam de diferenças nos coeficientes de expansão térmica dos materiais do substrato e do filme e de diferenças entre seus parâmetros de rede. A tensão interna de um filme pode ser de compressão ou de expansão. Filmes com tensões de compressão tendem a expandir paralelamente à superfície do substrato. Em casos extremos podem formar protuberâncias na superfície. Filmes com tensões de expansão tendem a se contrair paralelamente ao substrato.

É importante também citar que, em muitos casos, ao filme previamente crescido são aplicados tratamentos térmicos visando modificação das respectivas propriedades estruturais dos mesmos.

\subsection{Propriedades Magnéticas}

Os filmes finos apresentam uma variedade de propriedades magnéticas que possibilitam o uso dos mesmos em aplicações tecnológicas. A seguir serão descritas algumas dessas propriedades que são úteis para a tecnologia de gravação magnética.

\section{Anisotropia Magnética}

A anisotropia magnética é um dos fenômenos básicos presente em cada material magnético, o qual determina a orientação preferencial da magnetização espontânea $M$, ao 
longo de certas direções características de cada material. Ela decorre da interação entre o spin e o movimento orbital dos elétrons, denominado de interação spin-órbita. A energia necessária para vencer o acoplamento spin-órbita, girando o sistema de spins de um domínio fora da direção fácil de magnetização é chamada de energia de anisotropia magnética.

Uma expressão geral da energia de anisotropia magnética, para uma dada orientação da magnetização e da orientação relativa dos eixos do cristal, é uma função complexa refletindo a simetria total do sistema. Na análise da anisotropia de filmes, ela é em geral apresentada em uma descrição uniaxial dada por,

$$
\mathrm{E}=-K \cos ^{2} \theta
$$

onde $\theta$ é o ângulo entre a magnetização e a normal ao plano do filme e $K$ é uma constante que determina a intensidade da anisotropia [14]. A constante de anisotropia $K$ inclui todas as contribuições de várias fontes e é algumas vezes considerada como a constante de anisotropia efetiva $\left(K_{\mathrm{ef}}\right)$. Nos filmes, essa constante se desdobra entre contribuições de superfície e/ou interface e contribuições de volume.

Em filmes finos a anisotropia magnética é o resultado de contribuições de diversos tipos de anisotropia, onde as mais relevantes são: a anisotropia magnetocristalina, anisotropia de forma (ou dipolar magnética), anisotropia magnética de superfície e anisotropia magnetostrictiva [16].

a) anisotropia magnetocristalina - conhecida também como anisotropia do cristal, é uma propriedade intrínseca do material. As origens da anisotropia magnetocristalina fundamentam-se em mecanismos onde os momentos magnéticos de spin sentem a simetria da rede do cristal. Possui forte dependência estrutural. É determinante do comportamento magnético em monocristais. Em policristais, depende de fatores como: grau de texturização, morfologia dos grãos e da homogeneidade do filme. Uma descrição fenomenológica dessa propriedade permite encontrar o valor das constantes de anisotropia. Para sistemas com simetria axial temos:

$$
\mathrm{E}_{K}=\mathrm{K} \operatorname{sen}^{2} \theta+\mathrm{K}^{\prime} \operatorname{sen}^{4} \theta+\mathrm{K}^{\prime \prime} \operatorname{sen}^{6} \theta+\ldots
$$

onde $K$ é a constante de anisotropia uniaxial, $K^{\prime}$ e $K^{\prime \prime}$ são os termos de $2^{\text {a }}$ e $3^{\text {a }}$ ordem desta constante e $\theta$ é o ângulo entre a magnetização e o eixo de simetria;

b) anisotropia de forma - considerada como uma das mais importantes fontes de anisotropia magnética em filmes finos magnéticos, a anisotropia de forma revela o longo alcance da interação dipolar magnética sendo influenciada pelos limites geométricos da amostra. Ela 
disputa seu papel relativo no comportamento magnético dos filmes com a anisotropia magnetocristalina. A energia de anisotropia de forma sobre o volume do material é definida como:

$$
\mathrm{E}_{D}=-\frac{1}{2} \int \mathrm{M} \cdot \mathrm{H}_{D} d v
$$

onde $\mathbf{H}_{D}$ é o campo desmagnetizante anisotrópico, que para materiais ferromagnéticos elipsoidais pode ser descrito por $\mathbf{H}_{D}=-\eta M$, sendo $\eta$ o tensor desmagnetizante, dependente da geometria da amostra (varia de 0 a $4 \pi$, no sistema CGS);

c) anisotropia magnética de superfície - A perda de simetria em uma superfície ferromagnética resulta em uma anisotropia magnética de superfície. Normalmente as propriedades de um material na forma de um filme fino diferem substancialmente das propriedades do mesmo material na sua forma maciça devido à influência da superfície; a relação entre a superfície e o volume é muito maior no caso de um filme fino.

A contribuição para a energia de superfície $E_{S}$ é dada por:

$$
\mathrm{E}_{\mathrm{S}}=K_{\mathrm{S}} \cos ^{2} \theta
$$

onde $K_{\mathrm{S}}$ é a constante de anisotropia de superfície e $\theta$ é o ângulo entre a magnetização e a normal à superfície do filme;

c) anisotropia magnetostrictiva - este tipo de contribuição é relacionada com deformações mecânicas no material devido à sua magnetização. Essas deformações são anisotrópicas e dependem da direção da magnetização. No caso de uma deformação magnetostrictiva ocorrer na presença de uma tensão aplicada $\sigma$, a energia por unidade de volume associada a este efeito, para um meio elasticamente isotrópico, pode ser escrita como:

$$
\mathrm{E}_{\sigma}=-\frac{3}{2} \lambda_{s} \sigma \cos ^{2} \theta_{\sigma}
$$

onde $\lambda_{S}$ é a constante de magnetostricção que pode ser positiva, negativa ou em alguns casos nulo. Esse valor depende da magnetização e portanto do campo aplicado.

\section{Coercividade}

O fenômeno da coercividade é uma propriedade extrínseca do material. Ela está diretamente relacionada com a força de magnetização necessária para reduzir a zero, a 
densidade de fluxo magnético em um material magnético. Vários são os fatores que definem seu comportamento. Para filmes finos policristalinos, os fatores que afetam o valor da coercividade são [17], por exemplo, a anisotropia magnetocristalina, a composição do filme, o tamanho e a forma dos grãos, a densidade de defeitos estruturais e as interações do tipo magnetostáticas (de longo alcance) e de troca ou "exchange" (de curto alcance) entre os grãos, etc., tornando-se em geral, difícil determinar, individualmente, qual destes parâmetros possui uma importância relativa maior na determinação da coercividade. Todos eles possuem pesos relativos que dependem da microestrutura do filme.

A coercividade se relaciona com a estabilidade de uma mídia magnética no processo de armazenamento de dados. $\mathrm{O}$ aumento da densidade de gravação provoca um aumento dos campos desmagnetizantes presentes na mídia, o que gera a necessidade do aumento da coercividade para que a estabilidade do padrão de gravação seja mantida.

\section{Magnetoóptica}

Os fenômenos magnetoópticos correspondem a mudança da intensidade ou do estado de polarização da luz refletida ou transmitida através da superfície de um material magnético[14]. São observados somente em condições onde a amostra se encontra em um estado magnetizado. A magnetização produz mudanças no tensor dielétrico do material, o que gera variações no índice de refração do mesmo. Têm sua origem relacionada à interação spinórbita, pois os fenômenos magnéticos são devidos aos spins elctrôxicos, enquanto as propriedades ópticas estão basicamente relacionadas aos orbitais atômicos.

Normalmente, o efeito produzido na luz refletida sobre a superfície de um material magnetizado é geralmente conhecido como "Efeito Kerr Magnetoóptico" (MOKE), em homenagem ao escocês John Kerr que, em 1875, obteve as primeiras observações em materiais ferromagnéticos.

\section{Magnetoresistência (MR)}

Este fenômeno corresponde à propriedade dos materiais magnéticos terem sua resistência elétrica alterada sob ação de um campo magnético externo. Atualmente é aceito que o mecanismo básico da MR tem origem no espalhamento dependente do spin dos elétrons de condução que ocorre no interior dos metais de transição ferromagnéticos. A variação no valor da resistência surge através do espalhamento difuso dos elétrons. A mais de uma 
década, um aumento significativo deste fenômeno foi constatado em materiais granulares constituídos de partículas magnéticas nanométricas imersas em metais comuns $(\mathrm{Cu}, \mathrm{Ag}, \mathrm{Au}$, etc.) e em alguns filmes finos formados por multicamadas [5], o qual ficou conhecido como "Magnetoresistência Gigante" (GMR). Mais recentemente, a presença de uma MR mais que gigante, "colossal", têm sido observada em alguns óxidos de metais de transição[18].

\subsection{Filmes Finos de FePt}

O grande interesse de várias atividades de pesquisa pelo estudo dos filmes finos policristalinos de ligas Fe-Pt está relacionado com suas importantes propriedades magnéticas como: eixo de fácil magnetização perpendicular ao plano do filme (anisotropia magnética perpendicular), grande coercividade e alto sinal Kerr Polar magnetoóptico. Essas propriedades magnéticas são fortemente correlacionadas com as propriedades estruturais do material (tipo de estrutura cristalina, orientação cristalográfica, grau de ordenamento químico, etc.). Na literatura [19-22], é descrito que a alta coercividade e anisotropia magnética perpendicular em filmes de FePt, com composições iguais de Fe e Pt, surgem devido a presença da estrutura cristalina tetragonal de face centrada FCT (tipo $\mathrm{L}_{0}$ ), com orientação cristalográfica preferencial [001]. Esta estrutura é geralmente obtida com a preparação de amostras em elevadas temperaturas $\left(\mathrm{T}_{\mathrm{S}} \geq 600^{\circ} \mathrm{C}\right)$ ou pelo tratamento térmico dos filmes depois do processo de deposição. Sob condições normais de preparação (baixas temperaturas e ausência de efeitos de um crescimento induzido) verifica-se nos filmes a presença da estrutura cristalina cúbica de face centrada FCC (tipo A1), com orientação cristalográfica preferencial [111] ou [100]. As características da estrutura tipo A1 (FCC) (Fig.2.3(a)) são: baixo grau de ordenamento químico (átomos de Fe e Pt são distribuídos aleatoriamente na rede) e isotropia magnética. A estrutura tipo $\mathrm{L1}_{0}$ (FCT) (Fig.2.3(b)) possui alto grau de ordenamento químico e alta anisotropia magnetocristalina. Esta estrutura pode ser descrita como uma sequiência de planos (camadas) alternados formados, cada um, pelos diferentes átomos constituintes da liga, formando o que se denomina de uma super-rede. A relação entre os parâmetros de rede c/a para essa estrutura é menor do que um, o que indica a existência de uma forte contração do parâmetro de rede em uma direção perpendicular as camadas da super-rede (ao longo do eixoc). 


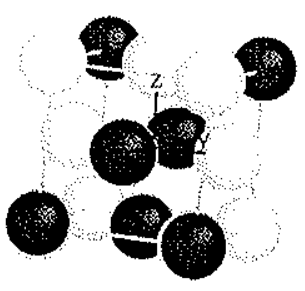

(a)

Fig. 2.3 - Estruturas cristalinas.(a) estrutura tipo A1 (FCC) (b) estrutura tipo L10

(FCT). (b)

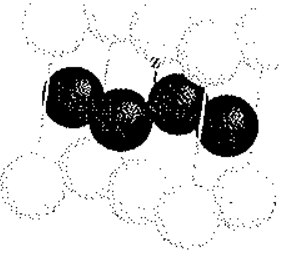

Pesquisas atualmente em desenvolvimento visam a obtenção de filmes de FePt com a estrutura tetragonal (FCT) ordenada e direção preferencial de crescimento [001] (com o eixoc ou eixo de fácil magnetização perpendicular ao plano) em baixas temperaturas de deposição, o que seria mais adequado para aplicações práticas dos filmes, como mídias de gravação magnética. Filmes de FePt com uma fase estrutural FCT(001) e alto grau de ordenamento químico, têm sido usualmente preparadas pelas técnicas de MBE [23] e "Sputtering Magnetron DC" [24,25] em altas temperaturas de deposição. Em outros casos, visando a redução da temperatura de ordenamento, utiliza-se de uma variedade de condições de preparação, dentre as quais citamos:

- subseqüente tratamento térmico ("annealing") [20,26];

- implantação iônica (feixes de $\mathrm{He}^{+}$) [27] em filmes de FePt depositados em baixas temperaturas;

- deposição de filmes de FePt sobre uma camada pré-depositada de um "buffer" [24,28] uu uma "underlayer" [29], com condições de induzir um crescimento da amostra na direção [001];

- adição de um terceiro elemento químico para a formação de uma liga ternária [30];

- deposição alternada de monocamadas atômicas de Fe e Pt, através de um elevado controle das taxas de deposição em sistemas que operam em condições de ultra-alto vácuo (UHV) [31];

Recentemente foi divulgado a possibilidade de preparação de filmes ordenados de FePt através da técnica de Deposição Eletroquímica [32]. Também, a preparação de nanopartículas de FePt, quimicamente sintetizadas como uma ordenada super-rede de partículas, foi demonstrada recentemente $[33,34]$.

Em nosso trabalho buscamos encontrar uma condição ideal para preparação de filmes de FePt com a fase estrutural ordenada FCT(001) em baixas temperaturas de deposição. Os 
nossos esforços se concentraram na otimização do processo de produção e no desenvolvimento de estudos que visaram uma melhor compreensão dos mecanismos de ordenamento estrutural nestes filmes e suas consequiências sobre as suas propriedades magnéticas. Preparamos e caracterizamos as propriedades estruturais e magnéticas de filmes finos de $\mathrm{FePt}$ crescidos sobre substratos amorfos de $\mathrm{SiO}_{2} / \mathrm{Si}(100)^{4}$ e monocristalinos de $\mathrm{Si}(100)$ e $\mathrm{MgO}(100)$, com e sem uma camada intermediária de um "buffer" de Pt. A utilização do "buffer" de Pt visa a obtenção de um substrato com uma estrutura mais favorável para forçar um crescimento "epitaxial" induzido dos grãos da liga FePt depositada sobre ele, nas condições desejadas. Utilizamos composições estequiométricas com $\sim 50$ at \% $\mathrm{Fe}$, e temperaturas de deposição de ambiente até $600^{\circ} \mathrm{C}$. Os filmes foram preparados através do método de deposição simultânea (codeposição) de elementos e também pelo método de deposição alternada de monocamadas atômicas, com o auxílio da técnica de "Sputtering Magnetron DC“. As análises de composição e espessura foram feitas através da técnica de Espectroscopia de Retroespalhamento Rutherford (RBS). As propriedades estruturais das amostras foram estudadas com o auxílio das técnicas de Difração de Raios-X (XRD) e Espectroscopia de Absorção de Raios-X (XAS). A caracterização magnética foi realizada através da técnica de Magnetometria de Amostra Vibrante (VSM), com medidas em temperatura ambiente.

No próximo capítulo apresentaremos em maiores detalhes os procedimentos experimentais utilizados para a preparação dos filmes de FePt.

\footnotetext{
"A espessura da camada amorfa de $\mathrm{SiO}_{2}$ é de aproximadamente $300 \mathrm{~nm}$.
} 


\section{CAPÍTULO 3}

\section{Técnica de Preparação}

Iniciamos este capítulo com uma breve descrição sobre a técnica de "Sputtering" utilizada na preparação dos filmes de FePt estudados neste trabalho. Em seguida apresentamos os procedimentos utilizados para a preparação dos filmes e os respectivos parâmetros de deposição. 
A necessidade de preparação de filmes com um rigoroso controle de estequiometria, visando aplicações práticas, impulsionou o desenvolvimento da técnica de preparação por "sputtering". Na tecnologia de fabricação de mídias magnéticas, o uso desta técnica é considerado como sendo quase universal, devido as suas importantes características como baixo custo de operação, alto grau de reprodutibilidade e grande facilidade de automatização.

\subsection{A Técnica de Sputtering}

A técnica de "Sputtering" se baseia na deposição de átomos por um método físico. $\mathrm{O}$ respectivo sistema consiste basicamente de uma câmara onde se trabalha em ambiente de alto vácuo $\left(10^{-4}\right.$ a $10^{-8}$ Torr $)$ preenchida com um gás de trabalho, usualmente argônio, em pressões da ordem de $10^{-3}$ a $10^{-4}$ Torr que, após ser ionizado, forma um plasma. Através de uma diferença de potencial, íons de argônio são direcionados para o alvo ${ }^{1}$ (cátodo) onde, através de colisões elásticas (transferência de momento linear), retiram átomos deste material ${ }^{2}$. Esses átomos deslocados migram na direção do substrato (ânodo) onde sobre a superficie alguns são depositados (com energias da ordem de $3 \mathrm{a} 10 \mathrm{eV}$ ). Este processo depende de uma variedade

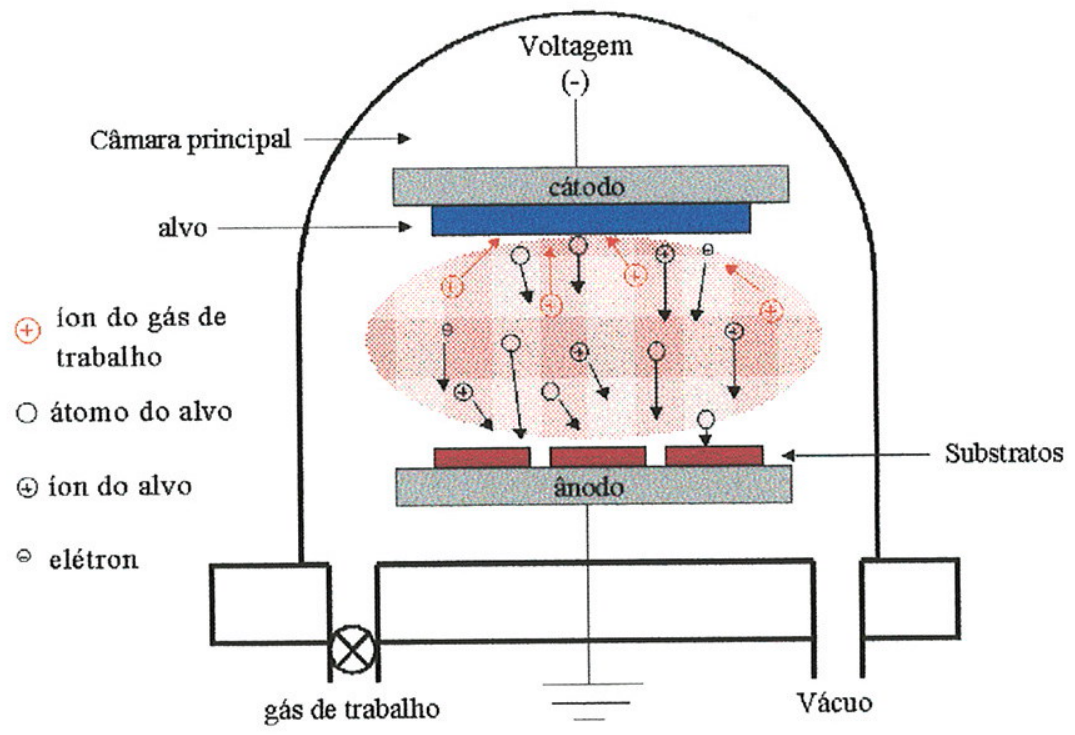

Fig. 3.1 - Esquema simplificado de um sistema de "sputtering".

\footnotetext{
${ }^{1}$ Os alvos contém a "matéria prima" utilizada para a formação do filme.

${ }^{2}$ Durante a colisão, elétrons secundários (ejetados do alvo), gases desorvidos, íons negativos e fótons também são emitidos do alvo [13]. Quando parte dos elétrons secundários ejetados colidem com os átomos neutros do gás de trabalho, gerando novos íons positivos, obtém-se um plasma estável (auto-sustentado).
} 
de fatores como valor da pressão do gás argônio, da diferença de potencial e a distância entre o alvo e o substrato [13]. Um diagrama esquemático de um sistema de "sputtering" é apresentado na Figura 3.1.

Dependendo da instrumentação, a técnica "Sputtering" é dividida em 4 categorias: "Sputtering DC", "Sputtering RF", "Sputtering Reativo" e "Sputtering Magnetron".

- Sputtering DC - a razão de deposição do filme depende da pressão do gás de trabalho na câmara de deposição e de variações da corrente. Os filmes preparados são normalmente de baixa densidade. As taxas de deposição são bastante baixas e somente alvos condutores podem ser utilizados;

- Sputtering RF - criada para ser usada como um meio de deposição de filmes finos isolantes. Um sinal pulsante de rádio frequiência (RF), na faixa de 5 a $30 \mathrm{MHz}$ é aplicado ao alvo. É empregada em casos onde os materiais usados como alvo possuem altas resistividades $\left(\geq 10^{6} \Omega \mathrm{cm}\right.$ ); os cátodos necessitam então de voltagens alternadas, para evitar o acúmulo de cargas elétricas superficiais no alvo.

- Sputtering Reativo - nesta categoria os compostos dos filmes são depositados no substrato por sputtering de alvos na presença de um gás reativo misturado com o gás argônio inerte. O filme obtido é uma liga sólida de um alvo metálico dopado com um elemento reativo, ou um composto, ou então alguma mistura dos dois;

- Sputtering Magnetron - É o tipo de sistema característico do equipamento utilizado na preparação de nossas amostras. Nesta categoria, canhões ("guns") de "sputtering" possuem imãs que fornecem um campo magnético para confinar o plasma próximo ao alvo e longe do substrato. Nos "guns" são montados os alvos. Este sistema de confinamento de íons por meio de configurações de campos magnéticos, produz um número maior de colisões íons-alvo. Possui importantes vantagens como: taxas de deposição substancialmente mais altas do que no "Sputtering DC" simples, plasma estável com baixas pressões do gás de trabalho, fluxo direcionado de partículas sobre o substrato e deposição de filmes mais densos. Proporcionam a deposição de filmes homogêneos, reprodutíveis, com boa aderência e com bom controle de espessura. 


\subsection{O Sistema de Sputtering Utilizado}

Para a preparação dos filmes de FePt estudados neste trabalho, utilizamos um sistema de "Sputtering Magnetron" ATC 2000 fabricado pela AJA Internacional, localizado no Laboratório de Materiais Magnéticos do Instituto de Física da USP. Ele consiste numa câmara principal de aproximadamente 90 litros, onde todo o processo de deposição ocorre. Uma câmara auxiliar ("load-lock"), de menor volume, permite que amostras produzidas sejam trocadas por substratos (acoplados a um porta-amostra) sem que a pressão de base da câmara principal seja afetada. As duas câmaras são separadas por uma válvula manual. Duas bombas turbo-moleculares são usadas no sistema de vácuo: uma para câmara principal com vazão nominal de 500 \&/s (modelo TCP380) e outra para o "load-lock" com uma vazão nominal de $50 \mathrm{e} / \mathrm{s}$ (modeloTCP015); outras duas bombas mecânicas ficam acopladas a cada turbo. Este arranjo de bombas permite atingir pressões de base de $2 \times 10^{-7}$ Torr na câmara principal e no "load-lock". A Figura. 3.2 mostra uma fotografia do sistema de "sputtering magnetron" utilizado.

A câmara principal utiliza 3 medidores de vácuo, um "ion gauge" para medidas de alto vácuo $\left(10^{-5}\right.$ a $10^{-8}$ Torr), um termoresistivo sensível a faixa desde a pressão atmosférica até $10^{-4}$ Torr e um Baratron, usado no controle de pressão durante o processo de deposição. Para monitorar a pressão no "load-lock", utiliza-se um sensor do tipo termoresistivo e outro do tipo "ion gauge".

Há 4 "guns" na câmara principal e espaço para montagem de mais um. Esta configuração possibilita fazer deposições com quatro alvos distintos, simultaneamente. Estes "guns" podem ser alimentadas por fontes de tensão elétrica contínua DC, ou com pulsos de rádio frequiência RF (13,56 Mhz). Cada fonte de alimentação tem potência máxima de $500 \mathrm{~W}$. Cada "gun" possui um controle de entrada do gás e controle do "shutter". Os "shutters" são obturadores que servem para bloquear o fluxo de material que é arrancado do alvo e direcionado para o substrato. Os alvos devem ter as dimensões de $5 \mathrm{~cm}$ de diâmetro e até 0.6 cm de espessura. Dois "guns" possuem uma configuração específica de campo magnetostático (imãs) para a deposição de materiais magnéticos. Podemos montar uma chaminé sobre cada gun para reduzir o espalhamento lateral dos átomos ejetados do alvo em relação ao substrato. Para evitar deposições preferenciais em certa direção no substrato mantemos o suporte que o contém (porta substrato) em rotação de até $20 \mathrm{rpm}$. 
A eficiência com que os átomos do alvo são arrancados pelos íons depende do respectivo "sputtering yield" de cada material. O "sputtering yield" é uma grandeza característica de cada material e é definido como o número de átomos que são arrancados do alvo por íon incidente. Este parâmetro depende, por exemplo, da energia de ligação entre os átomos que compõe o alvo, da densidade do alvo, etc. É importante também citar que este parâmetro é fortemente dependente do respectivo sistema de "sputtering" utilizado.

Para a deposição de filmes em temperaturas acima da ambiente (ou tratamento térmico após a deposição), o equipamento possui um sistema de aquecimento do substrato que consiste de duas lâmpadas halógenas acopladas a um controlador de temperatura (modelo MIC-1160, Partlow), protegidas por um refletor de alumínio e refrigerado com água. Deste modo, o porta substrato é aquecido pela radiação proveniente das duas lâmpadas, o que gera a possibilidade de atingir temperaturas de aproximadamente $650^{\circ} \mathrm{C}$ no substrato. A potência fornecida às lâmpadas é determinada pelo controlador de temperatura. Para deposições em temperaturas abaixo da ambiente, o equipamento possui um módulo que permite o resfriamento do substrato com nitrogênio líquido ou água.

Os gases utilizados no processo de plasma possuem pureza de $99.9999 \%$. Para o controle da pressão do gás de trabalho na câmara principal é utilizado um Controlador Adaptivo de Pressão (modelo VAT PM-5) associado a válvula de gaveta da turbo-molecular. O controle de vazão é realizado por um Controlador de Fluxo de Massa (modelo 1179A MKS) e por um Controlador de Quatro Canais (modelo 274C - MKS).

A taxa de deposição e a espessura do filme podem ser monitorados por um cristal dc quartzo oscilador associado a um equipamento microprocessado. Entrando com a densidade e a impedância acústica do material do alvo, ele fornece os valores da taxa de deposição e da espessura acumulada. Nós não utilizamos este sistema em nossas amostras.

Paralelamente à fabricação das amostras, utilizamos a técnica de caracterização de RBS para estabelecer valores de espessura e estequiometria, procurando corrigir as taxas efetivas de deposição. 


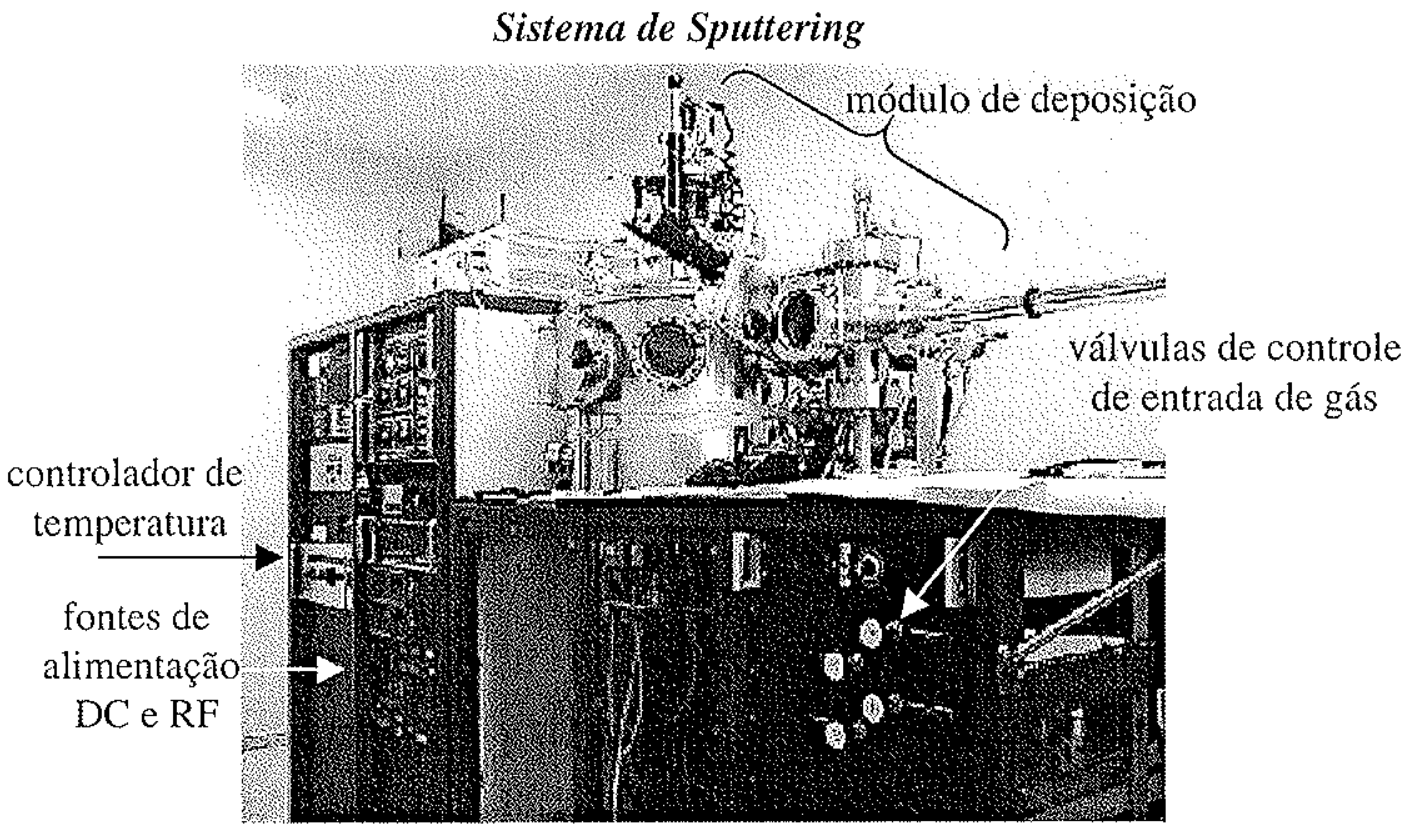

Módulo de deposição

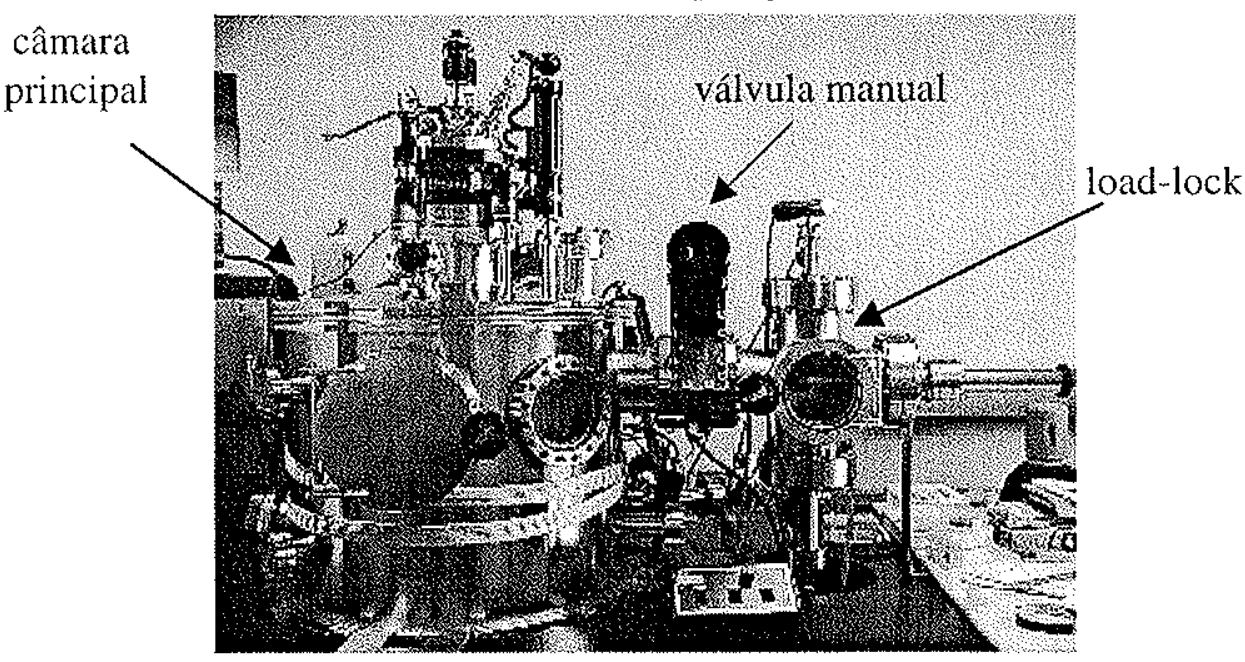

Interior da câmara principal
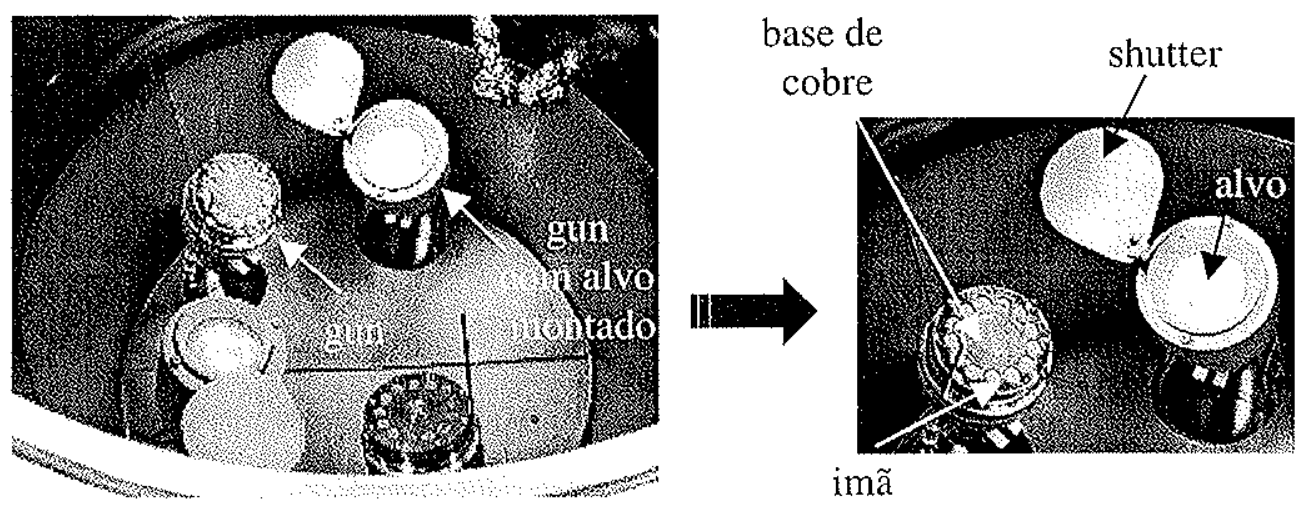

Fig. 3.2 - Sistema de "sputtering magnetron" utilizado para a preparação das amostras. 


\subsubsection{Características da Produção das Amostras}

Conforme já citado, os filmes finos de FePt foram preparados por dois métodos de deposição diferentes. No primeiro caso, utilizamos do método convencional de deposição simultânea (codeposição) de elementos. No segundo caso, utilizamos o método de deposição alternada de monocamadas atômicas (DAM). A configuração interna da câmara principal durante o processo de deposição, para os dois métodos, é apresentado na Figura 3.3. Em todos os casos, as deposições foram realizadas a partir de alvos de elementos puros de Fe e Pt. Trabalhamos com uma pressão de base na câmara principal da ordem de $\sim 10^{-7}$ Torr e o gás utilizado para obtenção do plasma foi o argônio (Ar) $(99,9999 \%)$, sob pressão de 5 mTorr, com fluxo de $20 \mathrm{sccm}$. Em todas as deposições, os "guns" foram alimentados pelas fontes do tipo DC. Os filmes finos de FePt foram crescidos sobre substratos amorfos de $\mathrm{SiO}_{2} / \mathrm{Si}(100)$ e monocristalinos de $\mathrm{Si}(100)$ e $\mathrm{MgO}(100)$, com e sem uma camada de um "buffer" de Pt .
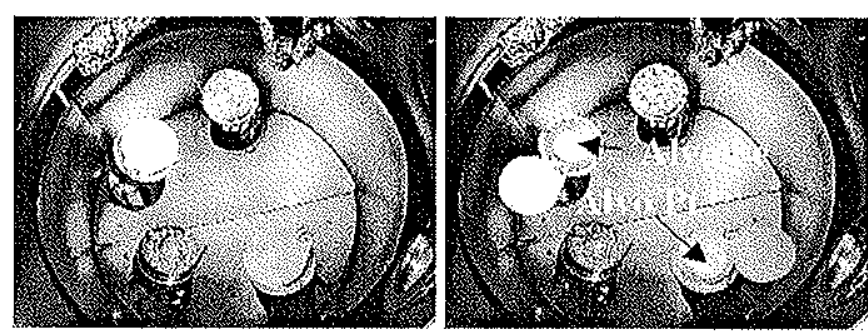

a)
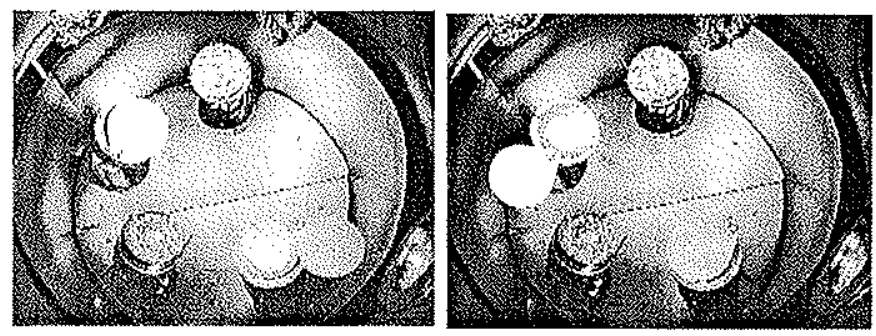

b)

Fig. 3.3 - Configuração interna da câmara principal durante o método de (a) codeposição (os dois "shutters" abertos simultaneamente) e (b) DAM (os "shutters" de cada "gun" são abertos em seqüência, permitindo a vazão de material e a respectiva deposição de camada por camada de cada elemento).

O porta substrato utilizado no processo de deposição possui uma configuração com doze janelas que permite a produção de doze filmes simultaneamente (seis sobre substratos com dimensões de $5 \times 5 \mathrm{~mm}^{2}$, três sobre substratos $10 \times 10 \mathrm{~mm}^{2}$ e três sobre substratos $10 \times 5$ $\mathrm{mm}^{2}$ ). Três obturadores cobrem as janelas quatro a quatro, os quais podem ser abertos ou 


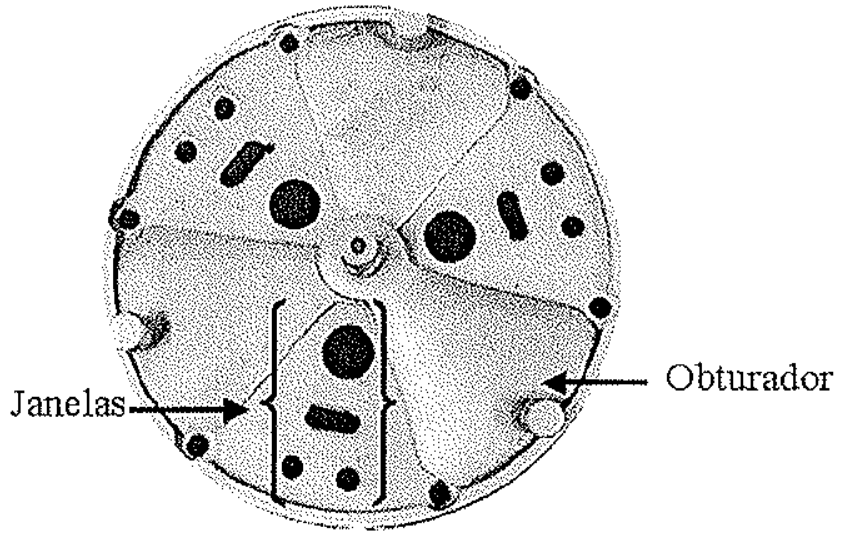

Fig. 3.4 - Imagem do porta substrato usado na produção das amostras.

fechados durante o processo de deposição (ver esquema na Fig. 3.4). Durante a deposição mantivemos o porta substrato em estado giratório para permitir a uniformidade da deposição.

Com o objetivo de eliminar possíveis contaminações existentes sobre a superfície do alvo, adotamos o procedimento de realizar uma pré-limpeza dos alvos antes de iniciar o processo de deposição do filme. Esta pré-limpeza foi obtida através do estabelecimento do plasma regular de deposição. Durante o processo protegemos o substrato mantendo o "shutter" fechado. O tempo utilizado durante a pré-limpeza foi de aproximadamente 5 minutos.

Para os filmes depositados pelo método de codeposição, os valores de taxas de deposição necessárias à preparação dos filmes, com as especificações desejadas, foram obtidas através de curvas de calibração para os alvos dos elementos de interesse. Para a montagem das curvas de calibração utilizamos dados obtidos através de análises de $\mathrm{RBS}^{3}$ de vários filmes puros de Fe e Pt e de ligas FePt, previamente preparados sobre vários valores de potência de "sputtering" $\left(P_{S}\right)^{4}$ e tempos de deposição. Utilizando calibrações desse tipo (RBS), pôde-se determinar que valores de $P_{S}$ usar com os diferentes alvos de modo a obter a composição desejada da camada magnética e o tempo de deposição necessário para atingir a espessura pretendida. Para a liga FePt, com composição de aproximadamente 50 at\% $\mathrm{Fe}$, obtivemos uma taxa de deposição de $\sim 1,55 \AA /$ s, utilizando-se $P_{S}(\mathrm{Fe}) \approx 300 \mathrm{~W}$ e $P_{S}(\mathrm{Pt})=75 \mathrm{~W}$. Filmes puros de Pt e o "buffer" de Pt foram depositados com uma razão de deposição de $0,9 \AA / \mathrm{s}$, utilizando-se $P_{S}(\mathrm{Pt})=75 \mathrm{~W}$. Os filmes preparados por este método foram depositados em temperaturas do substrato $\left(\mathrm{T}_{\mathrm{S}}\right)$ variando de ambiente até $600^{\circ} \mathrm{C}$.

Para a preparação de filmes de FePt pelo método de DAM, algumas modificações no sistema de "Sputtering" foram necessárias. Foram conectados dois relês temporizadores (tipo

\footnotetext{
${ }^{3}$ A técnica de RBS é apresentada em maiores detalhes no capítulo 4.

"Valor da potência na fonte de alimentação.
} 
HWKD) aos "shutters" de dois "guns" independentes. Os temporizadores foram utilizados para o controle automático do tempo de abertura e fechamento sequiencial dos "shutters", possibilitando a deposição alternada das camadas atômicas. Visando uma melhor acomodação atômica sobre a superfície do substrato, através da redução da energia dos átomos "sputterados", utilizamos valores reduzidos de $P_{S}$ de 90W (para o Fe) e 25W (para a Pt). Realizamos também um breve estudo sobre a influência do valor de pressão de deposição na obtenção da fase estrutural desejada para o filme. Os resultados deste estudo serão apresentados no capítulo 5. Os valores de taxa de deposição utilizados para a deposição de cada monocamada de $\mathrm{Fe}$ ou Pt foram obtidos através de uma sequiência de procedimentos básicos. Inicialmente consideramos os valores de densidade atômica planar do Fe ou da $\mathrm{Pt}$ como sendo aproximadamente iguais. Em seguida, calculamos o valor da densidade atômica planar para um material com uma estrutura tipo L1 $1_{0}$ (FCT) (ver Fig.2.3(b)) usando a seguinte relação:

$$
\sigma=\left(\frac{2 a \text { átomos }}{A}\right)=\left(\frac{2 \text { átomos }}{a^{2}}\right)
$$

onde $\boldsymbol{A}$ é a área de uma cela unitária e a o respectivo parâmetro de rede. O valor encontrado foi de $1,34 \times 10^{15}$ at. $/ \mathrm{cm}^{2}$. Na sequiência, preparamos filmes puros e espessos de Fe e de Pt e utilizamos a técnica de RBS para a determinação da espessura dessas amostras, os quais juntamente com os tempos de deposição de cada filme permitiu a obtenção das taxas de deposição. Por fim, combinamos, em alguns cálculos simples, os valores de tempo de deposição e a respectiva espessura de cada filme puro com o valor da densidade atômica planar para um material com uma estrutura $\mathrm{L}_{0}$, o que possibilitou a obtenção da taxa de deposição necessária a deposição de uma camada atômica de cada elemento. Usando $P_{S}(\mathrm{Fe})=$ $90 \mathrm{~W}$ and $P_{S}(\mathrm{Pt})=25 \mathrm{~W}$ este valor é de $\sim 0,11$ camada atômica/s, para ambos elementos Fe e Pt. Cada camada de Fe ou Pt foi depositada em uma sequiência de 90 repetições. Os filmes foram preparados em valores de $\mathrm{T}_{\mathrm{S}}$ variando de $200^{\circ} \mathrm{C}$ a $400^{\circ} \mathrm{C}$. 


\section{CAPÍTULO 4}

\section{Técnicas de Caracterização}

Neste capítulo, apresentaremos de forma objetiva os métodos utilizados para caracterizar as amostras deste trabalho. Na seção 4.1 descrevemos o método de caracterização utilizado para a determinação da espessura e composição (RBS). As demais seções se dedicam aos métodos utilizados para determinação das propriedades estruturais (XRD e XAS) e propriedades magnéticas (VSM). 
Em um trabalho científico experimental, a escolha adequada de técnicas experimentais de caracterização e o respectivo domínio das mesmas é de grande importância para o bom desenvolvimento das atividades de pesquisa. Descrevendo, de forma detalhada, as técnicas experimentais que foram utilizadas, pretendemos justificar a sua escolha, em função dos objetivos de nosso trabalho.

\subsection{Espectroscopia de Retroespalhamento Rutherford (RBS)}

Esta técnica envolve o espalhamento elástico de íons quando estes incidem sobre a superfície de um determinado material. Feixes de alta energia $(\mathrm{MeV})$ de íons de reduzida massa são usados por terem excelentes propriedades de penetração em filmes ou combinações filme-substrato. As partículas do feixe de íons colidem elasticamente com os átomos da amostra em estudo. A interação do feixe com a amostra é responsável pelo espalhamento das partículas. Assim, medidas de energia e do número de íons retroespalhados possibilitam identificar a composição e o perfil elementar em profundidade de filmes finos e materiais em geral. É importante salientar que a técnica de RBS é um método não destrutivo de análise. Um arranjo experimental típico de RBS é mostrado na Figura 4.1. Estaremos apresentando um breve resumo sobre os conceitos físicos envolvidos na técnica de RBS. Para uma descrição mais detalhada sugerimos uma consulta nas referências 35 e 36 .

Normalmente íns $\mathrm{He}^{+}, \mathrm{He}^{2+}$ são usados como feixes incidentes porque existe pequena

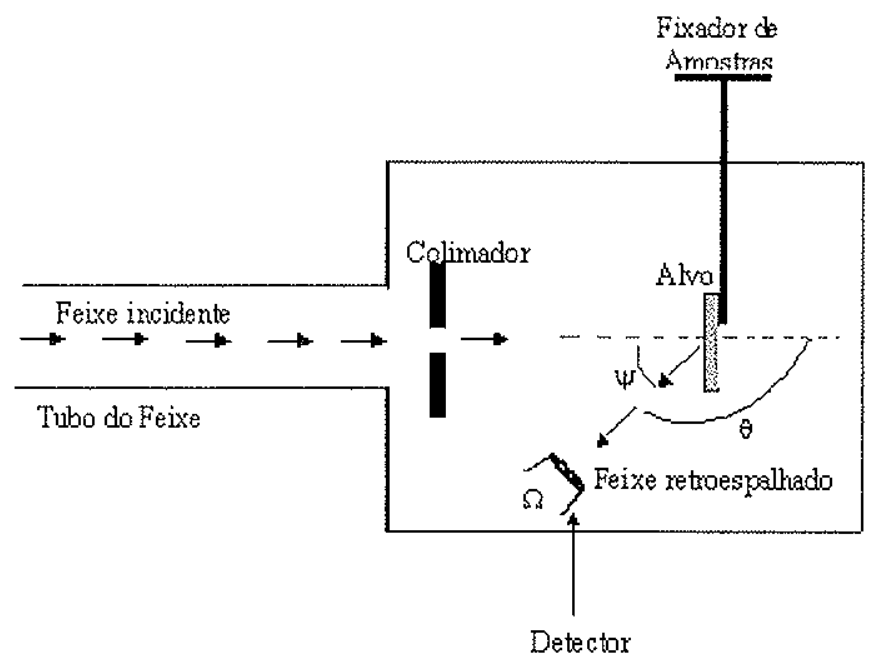

Fig. 4.1-Arranjo experimental simplificado de RBS. Na Figura, temos que $\theta$ é o ângulo de espalhamento, $\psi \circ$ ângulo entre o feixe incidente e o feixe retroespalhado e $\Omega$ o ângulo de deteç̧ão. 
interferência de reações nucleares, mas $\mathrm{H}^{+}$pode ser usado por proporcionar maior penetração.

Nas condições de análises por RBS, as interações entre as partículas do feixe e átomos do alvo podem ser descritas como colisões elásticas. Numa colisão elástica, as conservações da energia e do momento linear permitem calcular a razão entre a energia da partícula espalhada $(\mathrm{E})$ e sua energia inicial $\left(\mathrm{E}_{0}\right)$. Essa razão determina o valor de uma grandeza conhecida como Fator Cinemático K. É o conhecimento de K que permite discriminar os tipos de elementos químicos que compõem o alvo. Uma defïnição mais objetiva para o Fator Cinemático é apresentada como:

$$
\mathrm{K}_{m}=\frac{\mathrm{E}}{\mathrm{E}_{0}}=\left\{\frac{\left[1-\left(\frac{m}{\mathrm{M}} \operatorname{sen} \theta\right)^{2}\right]^{\frac{1}{2}}-\frac{m}{\mathrm{M}} \cos \theta}{1+\left(\frac{m}{\mathrm{M}}\right)}\right\}
$$

onde $\mathrm{m}$ e $\mathrm{M}$ são as massas atômicas da partícula do feixe e do átomo alvo, respectivamente, e $\theta$ o ângulo de espalhamento. O subscrito $m$ significa que $\mathrm{K}$ é o Fator Cinemático referente á colisão de uma partícula do feixe com um átomo do alvo. Através da equação 4.1 é possível verificar que a taxa de perda da energia da partícula espalhada depende da razão das massas da partícula incidente e do átomo alvo o que permite identificar o átomo no alvo. Pode-se verificar que o conhecimento do valor de $m$ e $E_{0}$ possibilita a determinação de $E$ para um determinado valor do ângulo $\theta$, deixando como única variável a ser determinada a respectiva massa $\mathrm{M}$ do alvo.

A probabilidade de uma partícula do feixe colidir com um átomo do alvo e ser retroespalhada a um ângulo $\psi$ em relação à direção de incidência do feixe para em seguida atingir o detector (Seção de Choque de Espalhamento) é definida como:

$$
s=\frac{1}{\Omega} \int_{\Omega} \frac{d s}{d \Omega} d \Omega
$$

onde $\Omega$ é o ângulo sólido do detector e $\frac{d s}{d \Omega}$ a seção de choque diferencial definida como:

$$
\frac{d s}{d \Omega}(\theta)=\frac{A}{Q . d \Omega . \sigma}
$$

Na equação 4.3, A é o número de partículas detectadas, $Q$ é o número de partículas que atinge o alvo e $\sigma$ a densidade de átomos na amostra em at $/ \mathrm{cm}^{2}$. Uma combinação entre as equações (4.2) e (4.3) permite escrever o número de partículas detectadas como:

$$
A=s \cdot \Omega \cdot Q \cdot \sigma
$$


Pode se verificar que conhecendo-se $s$ e $\Omega$ e determinando o número de partículas que atingem o alvo (e o detector), pode-se determinar a densidade atômica superficial (ou planar) do alvo.

Em uma primeira aproximação, quando íons se movem através da matéria, eles perdem energia por meio de colisões com elétrons de átomos do meio ${ }^{1}$. Considerando a perda de energia proporcional ao comprimento da trajetória percorrida pela partícula no interior do alvo, é possível estabelecer uma escala de profundidade e associar a energia da partícula detectada ao local onde ocorreu a colisão $[35,36]$. A grandeza que relaciona a variação da energia da partícula em função da espessura percorrida por ele dentro do alvo é conhecida como "Stopping Power" $(\varepsilon)$ o qual é definida como:

$$
\varepsilon=\left(\frac{1}{N}\right)\left(\frac{d E}{d x}\right)
$$

onde $d E / d x$ é a energia perdida pelo feixe, após percorrer uma certa distância $x$ dentro do alvo e $N$ o número de átomos de uma determinada espécie no alvo.

Nas análises por RBS obtemos um espectro de contagens em função da energia. Um espectro é na realidade um histograma onde o eixo das energias (abcissa) é dividido em 512 ou 1024 canais, sendo que no equipamento utilizado, cada canal corresponde a um intervalo de energia de $5 \mathrm{keV} / \mathrm{canal}$. Um espectro de RBS de um filme de composição $\mathrm{Fe}_{0.51} \mathrm{Pt}_{0.49} \mathrm{e}$ espessura 104 nm depositado sobre um substrato de Si(100) está representado na Figura 4.2. Sintetizando, a posição do pico de retroespalhamento de cada elemento (energia mais alta) é definida pelo Fator Cinemático (eq. 4.1). A intensidade relativa dos picos é lefinida pela Seção de Choque de Espalhamento (eq. 4.2) o qual fornece a composição do filme. A espessura do filme é definida pelo "Stopping Power" (eq. 4.5).

Nas análises, usam-se métodos iterativos e programas de simulação que permitem simular espectros RBS para uma dada composição/espessura da amostra. A comparação entre o espectro simulado e o espectro experimental permite determinar a composição e a espessura da amostra analisada. Exemplos de programas de simulação utilizados em análises de RBS são o Rump [37] e o SIMNRA [38].

A técnica de RBS é particularmente útil para a análise de filmes com até $2 \mu \mathrm{m}$ de espessura.

\footnotetext{
${ }^{1}$ A probabilidade de espalhamento nuclear é muito pequena quando comparada com a de interação com os elétrons, devido a reduzida dimensão do núcleo atômico.
} 


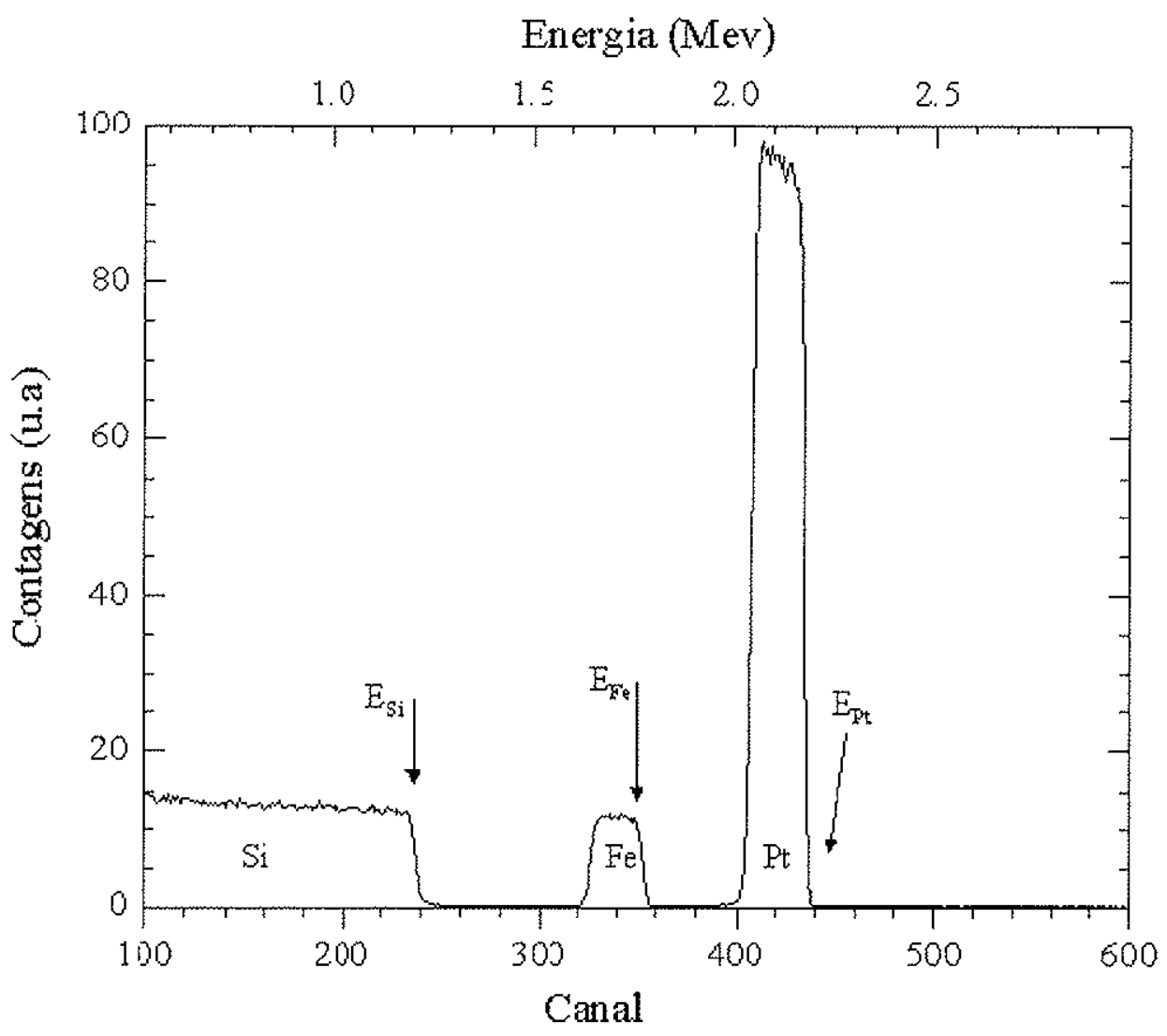

Fig. 4.2 - Espectro de RBS de um filme fino de $\mathrm{Fe}_{0.51} \mathrm{Pt}_{0.49}$ e espessura $104 \mathrm{~nm}$ depositado sobre um substrato de $\mathrm{Si}(100)$.

\subsubsection{Sistema Utilizado e Procedimentos Experimentais}

As medidas de RBS foram realizadas no Laboratório de Análises de Materiais por Feixe Iônico (LAMFI), localizado no Departamento de Física Nuclear do IFUSP. O equipamento utilizado consiste de um acelerador do tipo Pelletron-Tandem, modelo 5SDH (NEC - National Electrostatic Corporation), com tensão máxima no terminal de até 1,7MV. Duas fontes de íons alimentam o sistema, sendo uma de rádio freqüência (Alphatross), com câmara de troca de carga com vapor de rubídio e a outra tipo SNICS (Source of Negative Ions by Cesium Sputtering). Na atual configuração, o acelerador pode fornecer feixes de prótons e partículas alfa respectivamente com energias entre 0,6 e $3,4 \mathrm{MeV}$ e 0,6 e 5,1 MeV. A máxima corrente de feixe alcançada na amostra é da ordem de 100nA. O acelerador possui cinco terminais de saída $\left( \pm 30^{\circ}, \pm 15^{\circ}\right.$ e $\left.0^{\circ}\right)$ localizadas após o imã seletor, que também é usado para o controle de energia.

Os parâmetros experimentais utilizados foram: Feixe de $\mathrm{He}^{+}$com energia de 2.0 a 2.4

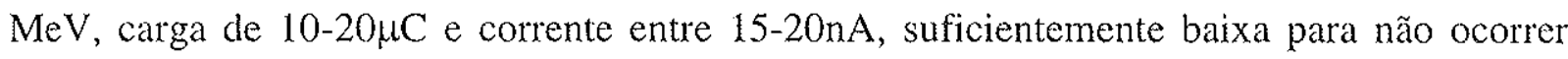
danos à amostra. Em todos os casos o detector foi mantido em $\psi=10^{\circ}$. 
Em todos os períodos de medida, adotamos o procedimento de calibrar a energia por canal. Essa calibração foi realizada através da obtenção de um espectro de RBS de um filme fino de uma liga de TiAlTa depositada sobre um substrato de carbono(C) (amostra de calibração), nas mesmas condições experimentais utilizadas para a obtenção dos espectros dos filmes de FePt.

Nas simulações dos espectros de RBS utilizamos o programa Rump [37]. A incerteza estimada para os valores de composição e espessura nos filmes é de 5\%.

\subsection{Difração de Raios-X (XRD)}

A Difração de Raios-X é uma poderosa ferramenta amplamente utilizada na determinação de características de estruturas cristalinas de materiais como: tipo de estrutura, identificação de materiais desconhecidos, orientação de monocristais, orientação cristalográfica preferencial de policristais, grau de ordenamento químico, defeitos, tensões, etc. É um fenômeno de interação entre radiação eletromagnética (raios-X) e a matéria ordenada. Para a ocorrência de difração é necessário que o comprimento de onda da radiação incidente seja da mesma ordem de grandeza do espaçamento interatômico do material analisado (da ordem de angstrons) [15].

Quando os raios-X incidem sobre os átomos ordenados de um cristal, ocorrem sucessivos espalhamentos, os quais fornecem um padrão de interferência construtivo ou destrutivo quando analisado em uma dada direção. No caso de um cristal, a sequiência ordenada e periódica de átomos, pode ser visualizada como um conjunto de planos, os quais são denominados planos cristalográficos e indexados através dos índices de Miller, hkl. O espalhamento coerente dos raios-X, por um conjunto de planos cristalinos (hkl) ocorre em um ângulo de Bragg. A condição de difração é estabelecida pela lei de Bragg:

$$
n \lambda=2 d_{h k l} \operatorname{sen} \theta_{h k l}
$$

sendo $\mathrm{n}$ a ordem de difração, $\lambda$ o comprimento de onda da radiação incidente, $d_{h k l}$ o espaçamento interplanar e $\theta_{h k l}$ o semi-ângulo de difração medido em relação à direção de propagação dos raios-X [39].

A intensidade da onda resultante do espalhamento do feixe incidente por todos os átomos na rede é determinada pelo Fator de Estrutura $(F)$. Este fator consiste da soma das 
intensidades de todas as ondas espalhadas por cada átomo individualmente. A expressão geral para o Fator de Estrutura é:

$$
F(h k l)=\sum_{n=1}^{N} f_{n} \exp \left[2 \pi i\left(h x_{n}+k y_{n}+l z_{n}\right)\right]
$$

onde $f_{n}$ é o fator de espalhamento atômico do n-ésimo átomo da base e $x_{n}, y_{n}$, e $z_{n}$ são as coordenadas do n-ésimo átomo na rede direta.

Espécies atômicas específicas influenciam a fase do feixe difratado e diferentes átomos na rede podem causar certos picos de difração, que podem ser visualizados no difratograma obtido em medidas de XRD. O difratograma de raios-X contém as posições e intensidades dos efeitos de difração, que é uma característica fundamental do material. A análise dos picos de difração permite determinar o valor de $\theta_{h k l}$ que, juntamente com o conhecimento de $\lambda$ tornam possível determinar o valor de $d_{h k l}$ e identificar o espaçamento da estrutura cristalina. Comparações entre os valores obtidos experimentalmente com os fornecidos pelas fichas do sistema JCPDS (Joint Committee on Powder Diffraction Standards) da International Crystal Structure Database, armazenado em CD-ROM ou listados em livros, permitem determinar o grupo espacial e as posições dos átomos na rede do material analisado. Cada ficha JCPDS apresenta informações sobre um padrão de difração do pó de um determinado material cristalino. Um padrão de difração do pó contém informações sobre o espalhamento de raios-X de todos os possíveis planos cristalinos na mesma proporção (sem orientação cristalográfica preferencial). Algumas fichas do sistema JCPDS da platina e da liga $\mathrm{Fe}_{x} \mathrm{Pt}_{1-x}(\mathrm{x} \approx 0,50)$ são apresentadas no apêndice $\mathrm{I}$.

Pelos dados de XRD, podemos também medir o tamanho médio dos grãos cristalinos e o grau de ordenamento químico do material analisado.

\section{a) Estudo do tamanho médio do grão cristalino}

Quando se analisa cristais perfeitos por XRD usando feixe paralelo e monocromático (condição ideal), obtemos difratogramas de raios-X com linhas finas para os picos de difração nos ângulos $2 \theta$ determinados pela Lei de Bragg. Porém, na ausência de condições ideais obtemos picos de difração alargados. Este alargamento é devido basicamente ao feixe incidente não ser totalmente monocromático e paralelo, e aos cristalitos, que difratam o feixe, terem tamanho finito.

Uma fórmula que relaciona o alargamento do pico de difração $\left(\beta_{h k l}\right)$ com o tamanho médio do grão cristalino responsável por ele $\left(D_{h k l}\right)$ é conhecida como Fórmula de Scherrer 
(equação(4.8)) [15]. Essa fórmula está relacionada com a diferença no caminho percorrido pelo feixe difratado nos diversos planos cristalinos ao longo da espessura do grão.

$$
D_{h k l}=\frac{0,89 \lambda}{\beta_{h k l} \cos \theta_{h k l}}
$$

Para obter o alargamento do pico causado pelo tamanho finito do grão, basta desconvoluir o alargamento da medida experimental do alargamento instrumental sendo esse valor dado por:

$$
\beta=\left(B^{2}-b^{2}\right)^{\frac{1}{2}}
$$

A largura a meia altura do pico de difração medida da amostra é expressa através de $B$. A largura a meia altura do pico de difração medido de uma amostra padrão, com valor $2 \theta_{h k l}$ próximo ao do material que estamos analisando, é expressa por $b$. No nosso caso, utilizamos como amostra padrão o $\mathrm{Al}_{2} \mathrm{O}_{3}$ monocristalino. $\mathrm{O}$ alargamento devido efetivamente ao tamanho do grão do material é expresso por $\beta$.

O valor de $\beta$ encontrado através da equação(4.9) é então usado na equação(4.8), para o cálculo do tamanho médio do grão do respectivo material cristalino em estudo. A incerteza no valor $D_{h k l}$ é calculada a partir da incerteza associada ao valor do ângulo $2 \theta$ e da incerteza da largura a meia altura do pico de difração.

Através dos valores obticlos para $D_{h k l}$, podemos analisar a coerência cristalina de um material policristalino. Quanto maior o valor de $D_{h k l}$ mais perfeitos são os cristalitos.

\section{b) Estudo do grau de ordenamento químico de longo alcance}

Através de análises de XRD também é possível a determinação do grau de ordenamento químico, numa escala de longo alcance, de materiais cristalinos.

Conforme já citado, dependendo das condições de preparação, uma liga $\mathrm{Fe}_{\mathrm{x}} \mathrm{Pt}_{1-\mathrm{x}}$ (com $\mathrm{x}=0.5$ ) pode ser formada por uma estrutura quimicamente desordenada tipo A1 (FCC) (átomos de $\mathrm{Fe}$ e Pt distribuídos aleatoriamente na rede) ou por uma estrutura tipo $\mathrm{Ll}_{0}$ (FCT), com ordenamento químico perfeito. A estrutura Llo pode ser visualizada como uma sequiência de planos alternados de átomos de $\mathrm{Fe}$ e Pt, formando o que é conhecido como uma super-rede. Quando comparamos difratogramas de raios-X de pó de ligas FePt com estruturas diferentes (Fig.4.3), observamos para a estrutura ordenada a presença de picos de difração (hkl) característicos, os quais são definidos como picos de difração da super-rede, além dos 


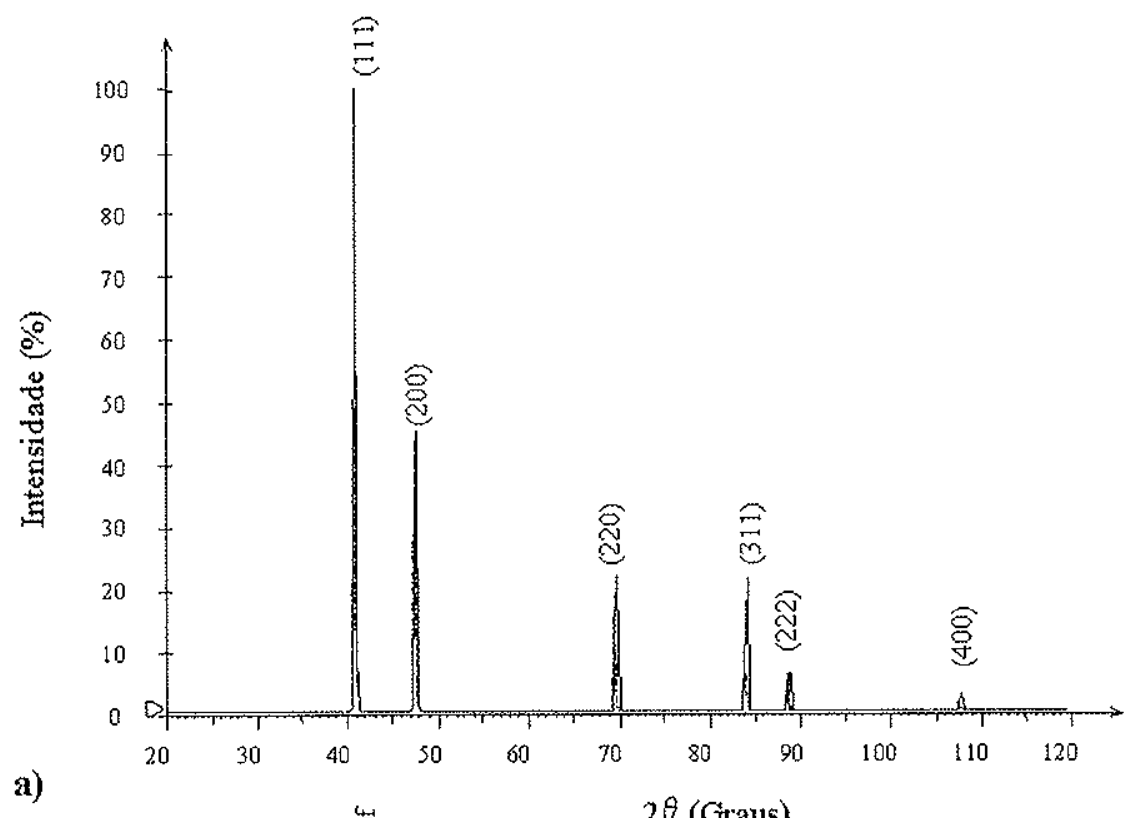

a)

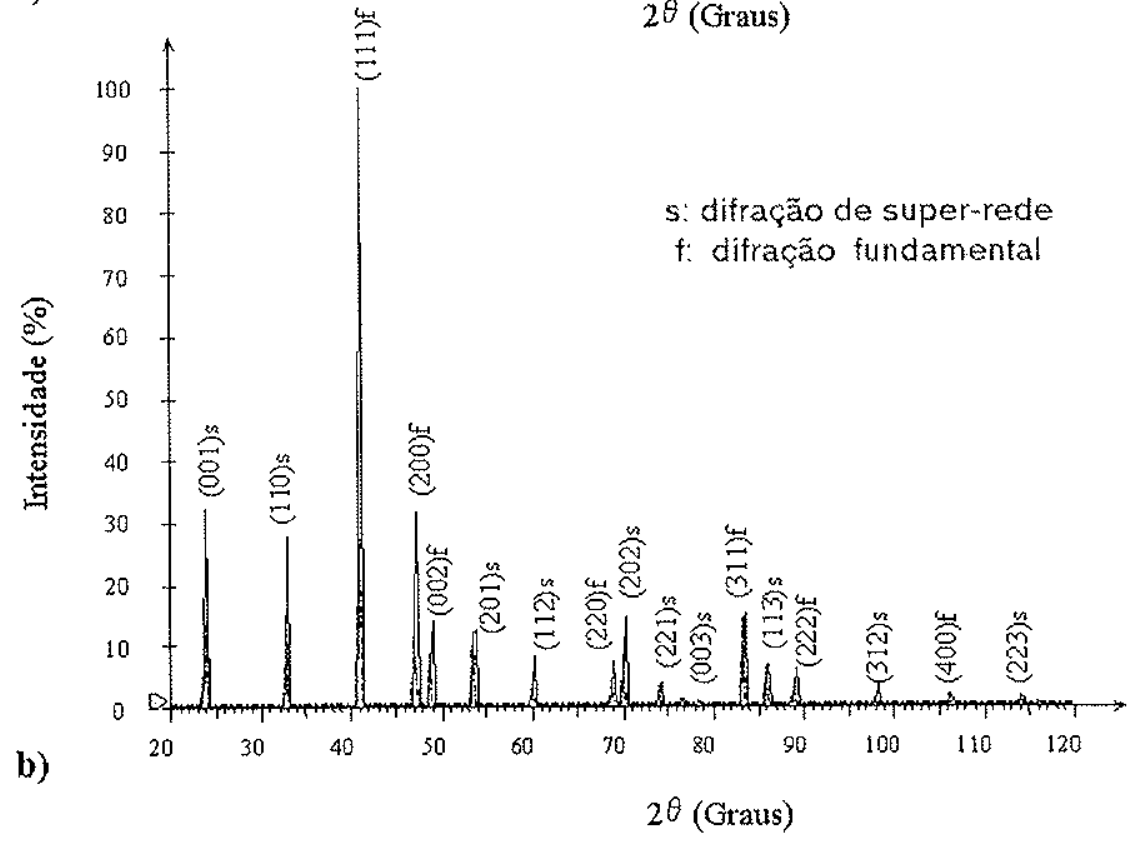

Fig. 4.3 - Difratogramas de raios-X de pó de uma liga $\mathrm{Fe}_{0.5} \mathrm{Pt}_{0.5}$ : (a) estrutura desordenada FCC; (b) estrutura ordenada FCT.

picos (hkl) semelhantes aos obtidos para uma estrutura desordenada (picos de difração fundamentais).

Para uma medida quantitativa do grau de ordenamento químico de longo alcance de materiais como os filmes de FePt, freqüentemente é utilizado um método simples e muito útil proposto por Warren [40], que consiste da seguinte relação:

$$
S^{2}=\left[\frac{I_{s}}{I_{f}}\right]_{\text {exp }}
$$

onde os termos $I_{s}$ e $I_{f}$ são as áreas integradas de picos de difração (hkl) de super-rede e fundamental, respectivamente. Os valores do parâmetro $S$ variam de 0 a 1 . Para $S=0$, temos 
um filme completamente desordenado e, para $S=1$, um filme com um perfeito ordenamento químico. Em nosso trabalho, determinamos o valor de $S$ através da relação (4.11), utilizando os valores de área integrada do picos de difração (001) de super-rede e (002) fundamental.

\subsubsection{Sistema Utilizado e Procedimentos Experimentais}

As análises de difração de raios-X foram feitas no Laboratório de Cristalografia do Departamento de Física Aplicada do IFUSP com a colaboração da Prof ${ }^{\mathfrak{n}}$. Dra. Márcia C. A. Fantini. As medidas foram realizadas em um difratômetro modelo URD-6 (Zeiss-Jena), em uma geometria $\theta-2 \theta$ (cada rotação da superfície da amostra em um ângulo $\theta$ em relação ao feixe incidente, o detector varia sua posição em $2 \theta)$, usando radiação $\mathrm{Cu}-\mathrm{K} \alpha(\lambda=1,5418 \AA)$ filtrada por uma lâmina de Ni. Para os filmes crescidos sobre substratos de $\mathrm{Si}(100)$ e $\mathrm{SiO}_{2}$, foram utilizados os seguintes parâmetros experimentais:

Tensão $=40 \mathrm{KV}$

Corrente $=20 \mathrm{~mA}$

Faixas $2 \theta=23^{\circ}-68,5^{\circ}$ e $69,5^{\circ}-93^{\circ}$

Passo $=0,05^{\circ}$

tempo $=4$ segundos de medida em cada ângulo;

Para os filmes crescidos sobre substratos de $\mathrm{MgO}(100)$ foram utilizados os seguintes parâmetros experimentais:

Tensão $=40 \mathrm{KV}$

Corrente $=20 \mathrm{~mA}$

Faixas $2 \theta=23^{\circ}-42.5^{\circ}$ e $43.5^{\circ}-93^{\circ}$

Passo $=0,05^{\circ}$

tempo $=4$ segundos de medida em cada ângulo;

Os valores de posição $(2 \theta)$, largura $(B)$ e área integrada $(I)$ dos picos de difração foram obtidos ajustando-se uma curva lorentziana em cada pico nos difratogramas de raios-X obtidos. Os valores de $\theta_{k k l}$ aplicados a equação (4.6) permitiram determinar os valores de espaçamento interplanar $\left(d_{h k l}\right)$ que, comparados com as fichas no sistema JCPDS, possibilitaram a determinação dos planos cristalográficos difratantes na amostra e o tipo de estrutura cristalina do filme. 


\subsection{Espectroscopia de Absorção de Raios-X (XAS)}

A Espectroscopia de Absorção de Raios-X ou XAS (X-ray Absorption Spectroscopy) é uma técnica largamente utilizada para a caracterização de materiais cristalinos e amorfos. O seu caráter de sonda local e a sua seletividade atômica possibilita investigações sobre a estrutura local de um determinado sistema (ordem estrutural de curto alcance), bem como o conhecimento da respectiva estrutura eletrônica do mesmo. Esta técnica está diretamente correlacionada com a medida da seção de choque para a absorção de fótons pelos elétrons existentes em determinados átomos. Apresentaremos de forma resumida os conceitos que envolvem a Espectroscopia de Absorção de Raios-X. Para um estudo mais aprofundado, com a obtenção de um formalismo teórico, sugerimos consultar a referência 41.

Para análises de XAS existe a necessidade de utilização de um espectro contínuo de radiação policromática, o que torna necessário o uso de fontes de radiação síncrotron. As experiências são realizadas em regiões do espectro tradicionalmente denominadas de raios-X 'moles' e raios-X 'duros'. A região dos raios-X 'moles' é caracterizada pela presença de fótons de baixa energia (de $\sim 100$ a $3000 \mathrm{eV}$ ), o que possibilita o estudo da borda $\mathrm{L}$ dos metais de transição (3d) ou borda $M$ dos lantanídeos (4f), diferentemente da região dos raios-X 'duros', caracterizada por fótons com energia superior a $2000 \mathrm{eV}$, o que possibilita o estudo da borda $\mathrm{K}$ dos metais de transição (3d) ou borda L dos lantanídeos (4p ou 5d) [42]. Em geral são as condições de vácuo ${ }^{2}$ que determinam quando se esta trabalhando com raios-X 'moles' ou 'duros'. Para as diferentes regiões do espectro são utilizadas tecnologias ópticas diferentes. Para a região dos raios-X 'moles' a escolha da energia dos fótons (monocromatização) é feita através de grades de difração, enquanto que na região dos raios- $X$ 'duros' são utilizados monocristais [43]. Quanto ao modo de deteç̧ão, em ambas regiões do espectro, a medida da absorção da amostra é normalmente feita medindo-se a quantidade de elétron secundários, ou a corrente elétrica que repõe os elétrons emitidos pela amostra, ou até mesmo pela fluorescência da amostra (radiação reemitida). Experimentos de XAS de materiais como os filmes finos, na região dos raios-X 'moles', possibilitam somente a análise das camadas superficiais do material. Por outro lado, na região de raios- $X$ duros, a alta energia do feixe permite uma maior penetração na amostra (da ordem de micrômetros). Em casos onde o feixe atravessa a amostra (amostras menos espessas ou com baixo grau absorção), frequientemente

\footnotetext{
2 Normalmente trabalha-se com raios-X 'moles' em condições de UHV (fótons de baixa energia são muito absorvidos pela matéria) e raios-X 'duros' em atmosfera ambiente (fótons de alta energia, baixo grau de absorção).
} 
também utiliza-se medidas de absorção por transmissão, no qual a intensidade do feixe é medida antes e após atravessar a amostra.

\subsubsection{Radiação Síncrotron}

A radiação síncroton é emitida quando partículas carregadas (elétrons ou pósitrons) relativísticas, são defletidas por campos magnéticos, fazendo com que as mesmas percorram uma órbita fechada. Normalmente todo este processo ocorre dentro de um sistema, em ambiente de ultra alto vácuo (UHV), conhecido como anel de armazenamento [42]. As partículas são defletidas e mantidas em órbita fechada por imãs dipolares. Para a correção da trajetória das partículas são utilizados eletroimãs quadrupolares e sextupolares. A deflexão das partículas provoca a emissão da radiação em uma direção tangencial à sua trajetória, sendo que praticamente toda intensidade emitida se encontra no plano da órbita. Dessa maneira a radiação emitida tem a forma de um leque (Fig. 4.4), que é parcialmente conduzida para fora do anel onde é utilizada nas diversas estações experimentais, chamadas de linhas de luz. Em um único anel de armazenamento podem existir diversas linhas de luz operando independentemente, sendo que o número depende em princípio da quantidade de dipolos que compõem a rede do anel de armazenamento, ou de quantas saídas de radiação existem em cada dipolo. A energia da radiação síncroton emitida pode abranger uma ampla faixa do espectro eletromagnético, dependendo do projeto do anel de armazenamento. Possui

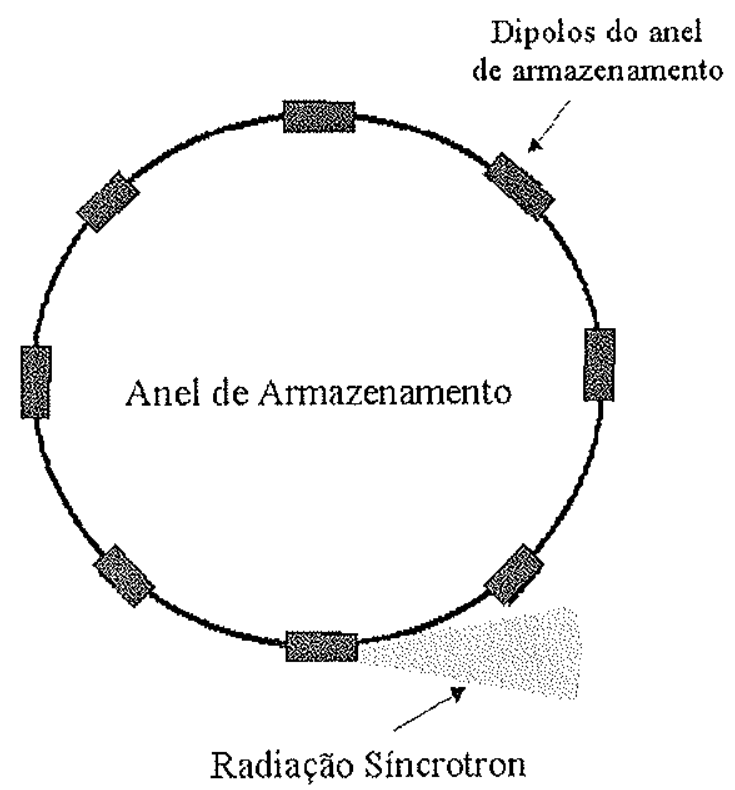

Fig. 4.4 - Ilustração do processo de emissão da radiação síncroton. 
importantes características como: alta intensidade, alta colimação, espectro de emissão contínuo e características bem definidas de polarização. Essas características explicam o motivo da técnica de XAS estar intimamente ligada com às fontes de radiação síncrotron. As fontes de raios-X clássicas produzem fótons com uma intensidade razoável apenas para algumas energias bem definidas correspondentes às emissões características (K$\alpha, \mathrm{L} \alpha$, etc.) dos diversos tubos ou lâmpadas disponíveis comercialmente. Por outro lado, uma fonte de radiação síncrotron fornece um feixe incidente monocromático sintonizável mediante o uso de monocromadores.

\subsubsection{Absorção de Raios-X}

Fótons podem ser absorvidos ou espalhados por um átomo através de diferentes processos. Entre estes processos citamos o efeito Compton, efeito fotoelétrico, etc A probabilidade de ocorrência de cada um destes processos depende do elemento absorvedor e da energia do fóton incidente. Na região de raios- $\mathrm{X}$, o processo mais comum é o efeito fotoelétrico. No efeito fotoelétrico os fótons são absorvidos num processo de interação que resulta na emissão de elétrons. Nesse processo, um átomo absorve um fóton quando este possui energia suficiente para promover elétrons do átomo para níveis energéticos superiores, desocupados, ou para o contínuo de energias (Fig. 4.5). Em condições onde o elétron é ejetado do átomo (fotoelétron), é observado que a respectiva energia cinética do mesmo é determinada pela diferença entre a energia do fóton absorvido e a energia die ligação desse elétron ao átomo [42]. No caso das técnicas de absorção, o fotoelétron permanece no material, interagindo com o mesmo.

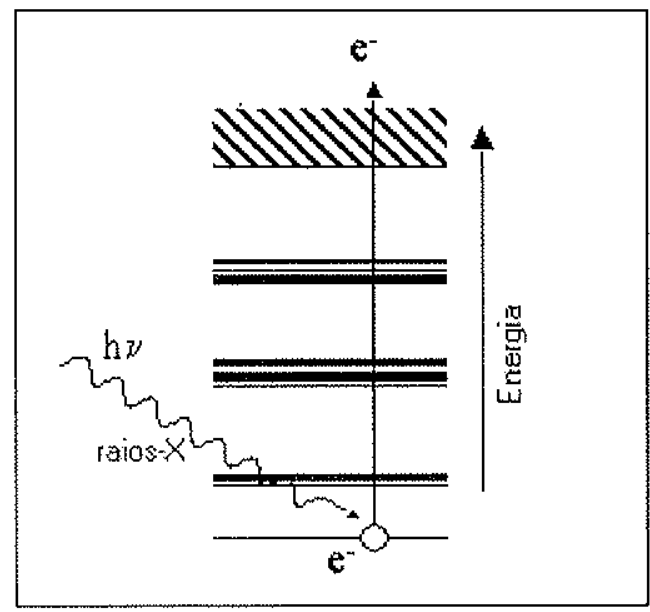

Fig. 4.5 - Diagrama esquemático da absorção de raios-X por um átomo isolado. 


\section{a) Absorção de Raios-X em Meios Condensados}

A absorção de um material, normalmente expressa em termos do coeficiente de absorção $(\mu)$, pode ser determinada através de medidas de atenuação dos raios-X sobre o material (Fig. 4.6).

$\mathrm{Na}$ Figura 4.6, I é a intensidade do feixe de fótons que atravessa um material de espessura $t$ quando a intensidade do feixe incidente é $I_{0}$. O coeficiente de absorção depende do material que se estuda e é uma função da energia. O produto $\mu t$ é chamado de absortância, sendo uma grandeza adimensional. O gráfico que relaciona a absorção (ou a absortância) de uma amostra com a energia é chamado de espectro de absorção. A medida clássica desse coeficiente é realizada no modo de transmissão conforme a Figura 4.6, onde a absorção é proporcional ao logaritmo de $I / I_{0}$. Um abrupto crescimento da absorção é observado quando a energia do fóton incidente é suficiente para excitar um elétron das camadas mais internas do átomo (camada $\mathrm{K}, \mathrm{L}$ ou $\mathrm{M}$ ) constituinte do material. A região que compreende esse salto no valor da absorção é conhecida como borda de absorção. O valor em energia dessa borda de absorção é uma característica de cada elemento químico. Como os espectros de absorção são obtidos em torno da borda de um dos elementos do material em estudo, pode-se verificar que a Espectroscopia de Absorção de Raios-X é uma técnica sensível ao elemento.

É importante também citar que a absorção depende da polarização da radiação incidente. Esta característica permite a obtenção de informações seletivas sobre diferentes orientações do material em estudo. Para átomos isolados, o coeficiente de absorção decresce monotonicamente como uma função da energia além da borơa de aborção (Fig. 4.7(a)). Para átomos em uma molécula ou embutidos em uma fase condensada, observa-se, acima do limiar da borda, uma variação oscilatória do coeficiente de absorção como uma função da energia do fóton (Fig. 4.7(b)). Essas oscilações são denominadas de Estrutura Fina de Absorção de Raios-X e são explicadas como sendo devido a interação dos fotoelétrons criados durante o processo de absorção com a estrutura de ordem local ao redor do átomo absorvedor (ver esquema representativo na Figura 4.7(c)).

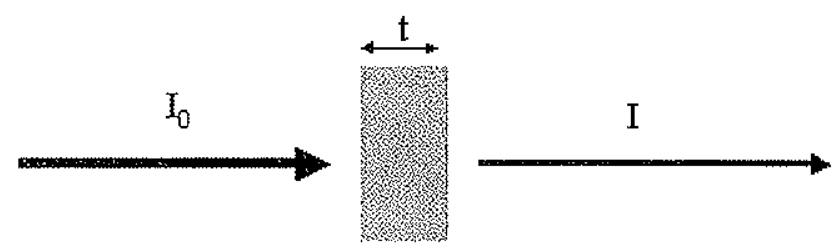

IFig. 4.6 - Diagrama esquemático da absorção de raios-X em meios condensados. 


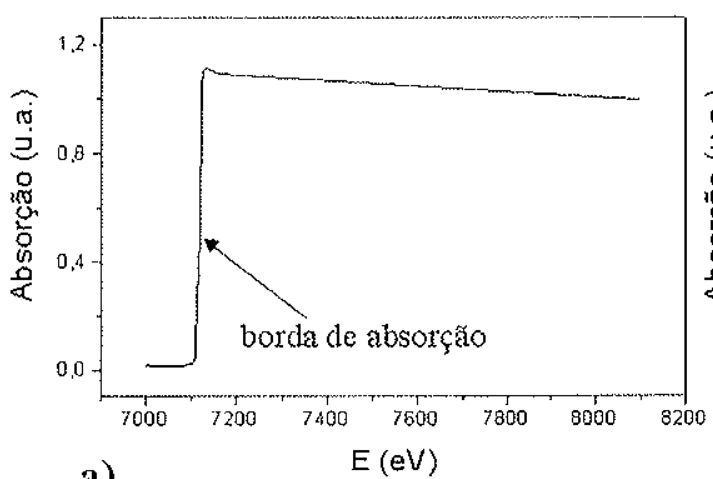

a)

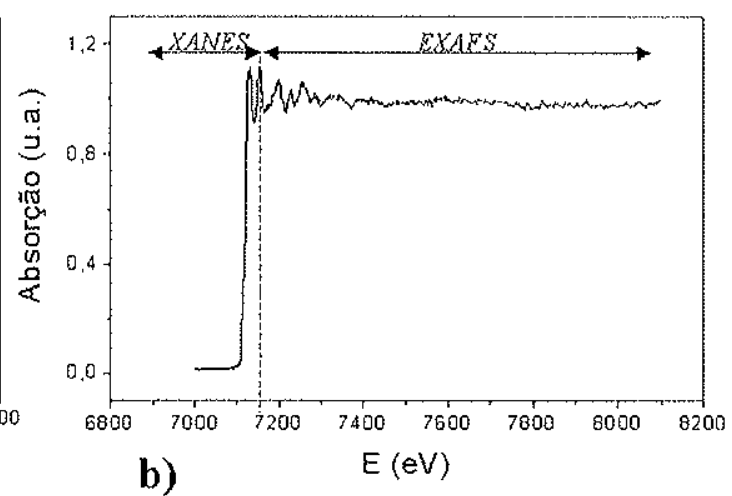

b) c)

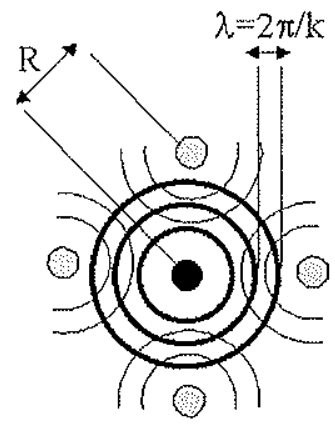

- Átomo absorvector

- Atomo espalhador

- Função de oncha emergente

- Função kle onরla retroespalhada

$\mathbf{R}$ distância entre o átomo

absorvedor e o átomo espalhador

Fig. 4.7 - Espectros de XAS característicos para (a) átomos isolados e (b) embutido em uma fase condensada. Note-se o aparecimento de oscilações após a borda de absorção no caso em que o átomo está em uma fase condensada. Em (c), uma representação esquemática mostrando que as oscilações são devido ao processo de interação do fotoelétron criado durante o processo de absorção (representado como uma onda esférica que sai do absorvedor) com a estrutura de ordem local. Essa onda é refletida pelos átomos espalhadores, retornando ao átomo absorvedor e interferindo com a onda inicial.

Tipicamente, considera-se um espectro de absorção como sendo dividido em duas partes: uma região conhecida como Estrutura Próxima a Borda de Absorção de Raios-X (XANES) e a outra como Estrutura Fina Estendida de Absorção de Raios-X (EXAFS) (ver Fig.4.7 (b)).

\section{Região de XANES}

Esta região compreende uma faixa que vai até aproximadamente $50 \mathrm{eV}$ acima da borda de absorção. Em análises de XAS, esta região é geralmente explorada por conter informações sobre a configuração eletrônica (valência e densidades de estados) e a simetria do sítio do átomo absorvedor. Sabe-se que a posição e a forma da borda de absorção é sensível ao estado de valência, tipo de ligante e a esfera de coordenação. 
Na região de XANES, os efeitos de espalhamento múltiplo ${ }^{3}$ são dominantes.

Os dados experimentais de XANES frequientemente são interpretados simulando-se espectros teóricos de absorção usando princípios básicos (análise qualitativa). Um método amplamente utilizado em diversas pesquisas consiste do uso de cálculos ab initio ${ }^{4}$ para simular espectros de XANES para uma determinada estrutura e compará-los com os espectros obtidos experimentalmente.

\section{Região de EXAFS}

A região de EXAFS compreende a faixa da variação oscilatória do coeficiente de absorção (aproximadamente 40 a $1000 \mathrm{eV}$ acima da borda de absorção). Esta região contém informações sobre a estrutura atômica local ao redor do átomo absorvedor (natureza e número de vizinhos, e suas distâncias em relação ao átomo central, ) $[41,43]$.

Para o tratamento e a respectiva análise de dados de EXAFS, primeiramente extraímos o respectivo sinal do espectro de absorção bruto (Fig. 4.8(b)), com base na seguinte relação:

$$
\chi(E)=\left(\mu-\mu_{1}\right) /\left(\mu_{l}-\mu_{0}\right)
$$

onde $\mu$ é o coeficiente de absorção total da amostra, $\mu_{0}$ o coeficiente de absorção atômico devido aos elétrons pertencentes as camadas diferentes da estudada e $\mu_{l}$ o coeficiente de absorção atômico do elemento devido aos elétrons pertencentes a camada em estudo. Usualmente utiliza-se o procedimento de mudar a dependência do espectro como uma função da energia $(E)$ do fóton para uma função do módulo do vetor de onda fotoelétron $(k)$, usando a relação $k=\left[2 m\left(E-E_{0}\right) / \hbar^{2}\right]^{1 / 2}$, sendo $E$ a energia do fóton absorvido, $E_{0}$ é a energia de ligação do elétron excitado e $m$ a massa do elétron. Dentro de algumas aproximações, o sinal de EXAFS é descrito como um somatório de funções senoidais, onde cada função está associada com uma esfera de coordenação em torno do átomo absorvedor. A amplitude de cada função está relacionada com o número de átomos que compõem essa esfera de coordenação,

\footnotetext{
${ }^{3}$ Efeitos de espalhamento múltiplo são devidos a condições onde o fotoelétron é espalhado por diversos átomos vizinhos antes de seu retorno ao átomo central (absorvedor).

${ }^{4} \mathrm{O}$ método $a b$ initio (ou método de primeiros princípios) emprega a Mecânica Quântica e o Eletromagnetismo para o cálculo de energias em sólidos, usando o conceito de modelagem computacional de materiais, que consiste em simular ou recriar a realidade física dos átomos de um material através de programas de computador. Esta metodologia permite que as diversas propriedades de um material que dependam da energia total do sistema ou de diferenças de energia (por exemplo, parâmetro de rede, compressibilidade, distâncias interatômicas, energia de formação, etc.) possam ser determinadas com extrema precisão. Outra característica bastante atraente do método é sua versatilidade: pode ser aplicado (com graus de dificuldade variados) para diversos tipos de materiais (metais, isolantes, semicondutores, moléculas) nas mais diversas situações ("bulk", superfícies, interfaces, defeitos, etc.).
} 
enquanto sua frequiência está relacionada à distância dessa esfera de coordenação até o átomo absorvedor. Com a finalidade de isolar a contribuição de cada esfera de coordenação para o sinal de EXAFS, calculamos a transformada de Fourier (TF) do mesmo (Fig.4.8(c)), mudando a dependência do espaço recíproco (módulo de vetor de onda) para a dependência no espaço real (distribuição radial das esferas de coordenação em torno do absorvedor). Para isolar a contribuição de cada esfera de coordenação do sinal de EXAFS, utiliza-se da TF inversa do intervalo que contém o pico correspondente à esfera de coordenação na qual estamos interessados (Fig.4.8(d)). Pode-se verificar que a TF funciona como um filtro que permite selecionar a esfera de coordenação na qual estamos interessados. Nas análises, usam-se métodos iterativos e rotinas de cálculo que permitem ajustar espectros teóricos de EXAFS aos respectivos dados experimentais. Essas simulações teóricas são realizadas com base na equação de EXAFS, definida no espaço em $k$ como:

$$
\chi(k)=\sum_{i} N_{i} S_{O}^{2} F_{i}(k) \exp \left(-2 \sigma_{i}^{2} k^{2}\right) \exp \left(-2 r_{i} / \lambda(k)\right) \frac{\operatorname{sen}\left(2 k r_{i}+\phi_{i}(k)\right)}{k r_{i}^{2}}
$$

Na equação (4.13) os parâmetros se dividem em duas classes:

a) parâmetros estruturais

- $N_{i}$ - número de átomos na i-ésima camada de átomos;

- $\sigma_{i}$ - fator de Debye Waller da i-ésima camada de átomos, correlacionado com uma possível desordem do material estudado (provenientes de vibrações térmicas ou uma provável desordem estrutural);

- $r_{i}$ - distância média entre os átomos na i-ésima camada de átomos e o átomo absorvedor.

b) parâmetros atômicos

- $S_{0}{ }^{2}$ - fator de redução da amplitude devido a efeitos de correlação eletrônica;

- $F_{i}(k)$ - amplitude de retroespalhamento do fotoelétron pelos átomos vizinhos;

- $\lambda(k)$ - livre caminho médio do fotoelétron;

- $\phi_{i}(k)$ - defasagem devida aos potênciais dos átomos absorvedor e espalhador; 

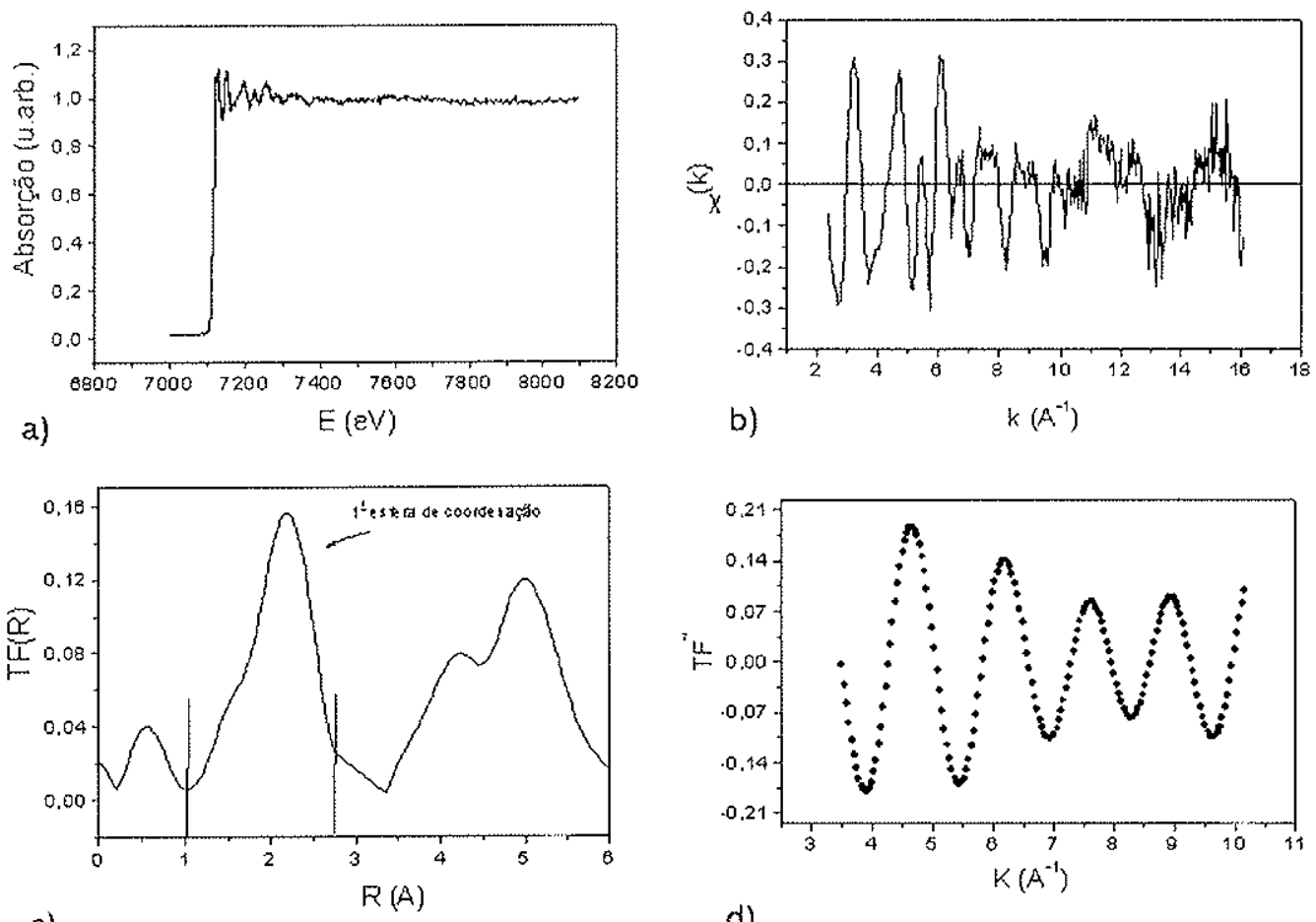

c)

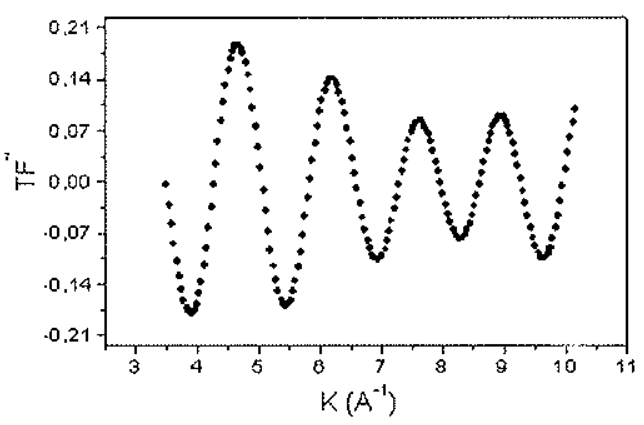

d)

Fig. 4.8 - Resumo do processo de extração de dados de EXAFS. (a) Espectro de absorção de um filme de FePt. (b) Oscilações de EXAFS extraídas de (a). (c) Transformada de Fourier das oscilações presentes em (b). (d) Oscilações de EXAFS correspondentes apenas a primeira esfera de vizinhos, obtidas através de uma transformada inversa de Fourier da região definida em $(c)$.

Assim, usando a equação (4.13), é possível modelar os dados experimentais, e obter os parâmetros estruturais desejados. Os valores de fator de fase $\left(\phi_{i}(k)\right)$ e amplitude $\left(F_{i}(k)\right)$ podem ser obtidos a partir de dados experimentais de um material como referência ou podem também ser obtidos usando métodos $a b$ initio, levando-se em consideração informações estruturais de prévio conhecimento sobre o sistema em estudo. É importante citar que a obtenção de um ajuste de EXAFS pode se tornar uma tarefa difícil, dependendo da estrutura e propriedades do material estudado, e do tipo de informações desejadas.

\subsubsection{Sistema Utilizado e Procedimentos Experimentais}

Os experimentos de Espectroscopia de Absorção de Raios-X dos filmes finos de FePt foram realizados na borda-K do $\mathrm{Fe}(7112 \mathrm{eV})$, em temperatura ambiente, na linha de luz D04B-XAS do Laboratório Nacional de Luz Síncroton (LNLS), localizado na cidade de Campinas (São Paulo-SP). Esta linha de Luz opera na faixa de raios-X duros (de 2.5 a 24 $\mathrm{KeV})$. O monocromador utilizado é um cristal sulcado de $\mathrm{Si}(111)$. Os dados foram coletados no modo de deteção por fluorescência, através de um sistema composto por 15 detectores 
independentes de Ge com grande ângulo sólido de coleta. No modo de detecção por fluorescência a absorção é proporcional a $I_{f} / I_{0}$, onde $I_{f}$ é a quantidade de fótons de fluorescência, e $I_{0}$ a intensidade da radiação incidente. $O$ uso deste modo de detecção foi devido a maior facilidade de remoção de prováveis picos de Bragg, muitas vezes presentes em espectros de XAS de amostras cristalinas, que se sobrepõem as oscilações de EXAFS dificultando a extração de um sinal puro.

Medidas em função da polarização do campo elétrico foram realizadas ajustando-se o ângulo $(\theta)$ entre a radiação incidente e a normal ao plano do filme para valores de $15^{\circ}, 36^{\circ} \mathrm{e}$ $75^{\circ}$, possibilitando a obtenção de informações seletivas sobre diferentes orientações do filme (ver esquema na Fig.4.9). Os espectros de XAS foram obtidos de acordo com os seguintes parâmetros experimentais descritos na Tabela 4.1. Para a calibração da posição em energia dos espectros de absorção obtidos, dependente da calibração do monocromador, adotamos o procedimento de monitorar, antes da obtenção de cada espectro de XAS dos filmes de FePt, a posição da borda de absorção de uma folha de Fe metálico (amostra padrão) através de medidas por transmissão, usando câmaras de ionização posicionadas antes e após a folha. Este método possibilitou certificar a posição em energia dos espectros com precisão da ordem de $0.1 \mathrm{eV}$.

Como região de XANES consideramos os dados obtidos de 7100 a $7180 \mathrm{eV}$. Para a extração dos dados de EXAFS do espectro de absorção bruto utilizamos o programa EXAFS pour le Mac [48]. Nas simulações de XANES e EXAFS contamos com a colaboração do Dr. Rogério Junqueira Prado. As simulações foram realizadas com o auxílio do código FEFF8 [44-46]. As simulações de XANES foram geradas considerando-se um "cluster" de 228 átomos.

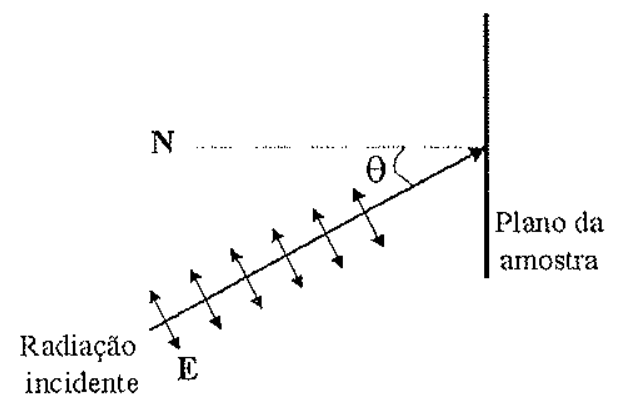

Fig. 4.9 - Configuração utilizada para medidas de XAS em função da polarização do vetor campo elétrico (E). 
Tabela 4.1 - Parâmetros experimentais utilizados na obtenção dos espectros de XAS dos filmes de FePt.

\begin{tabular}{|c|c|c|}
\hline Range & Passo & Tempo \\
\hline $7000-7090 \mathrm{eV}$ & $5 \mathrm{eV}$ & $1 \mathrm{seg}$ \\
\hline $7090-7160 \mathrm{eV}$ & $0,4 \mathrm{eV}$ & $2 \mathrm{seg}$ \\
\hline $7160-7300 \mathrm{eV}$ & $1 \mathrm{eV}$ & $2 \mathrm{seg}$ \\
\hline $7300-7600 \mathrm{eV}$ & $2 \mathrm{eV}$ & $3 \mathrm{seg}$ \\
\hline $7600-8100 \mathrm{eV}$ & $4 \mathrm{eV}$ & $4 \mathrm{seg}$ \\
\hline
\end{tabular}

\subsection{Magnetometria de Amostra Vibrante (VSM)}

Amplamente utilizada na caracterização de materiais magnéticos, devido a facilidade de operação, a técnica de VSM tem como princípio físico a indução eletromagnética descrita pela lei de Faraday, ou seja, a variação temporal do fluxo magnético numa dada superfície produzindo um sinal elétrico.

Um equipamento de VSM mede o momento magnético total das amostras, em função do campo magnético aplicado $(\mathrm{H})$, através do sinal induzido pelo movimento da amostra em um conjunto de bobinas sensoras "pick up" [49]. A amostra a ser caracterizada é fixada em um porta amostra preso a uma haste rígida não metálica e não magnética no centro geométrico das bobinas sensoras, de modo a estar sujeito a um campo magnético constante, gerado pelo eletroimã. A outra extremidade da haste é presa na "cabeça" do magnetômetro, e vibra numa frequiência de $\sim 83 \mathrm{~Hz}$, na direção longitudinal da haste. Para os filmes finos magnéticos, é possível estudar o momento magnético total em função da orientação do campo magnético aplicado (curvas de histerese) no plano (geometria no plano) e perpendicular ao plano do filme (geometria fora do plano). Um diagrama esquemático de um VSM é mostrado na Figura 4.10.

Da curva de histerese obtida é possível tirar informações como: valores de magnetização de saturação $\left(M_{S}\right)$, campo coercivo $\left(H_{C}\right)$ e magnetização remanente $\left(M_{r}\right)$, conforme ilustrado na Figura 4.11. Para um filme fino magnético, a forma da curva de histerese, caracterizada principalmente por $M_{S}, H_{C}$ e $M_{r}$, depende da composição, das condições de preparação, do tratamento (térmico, magnético), da anisotropia cristalina, do 


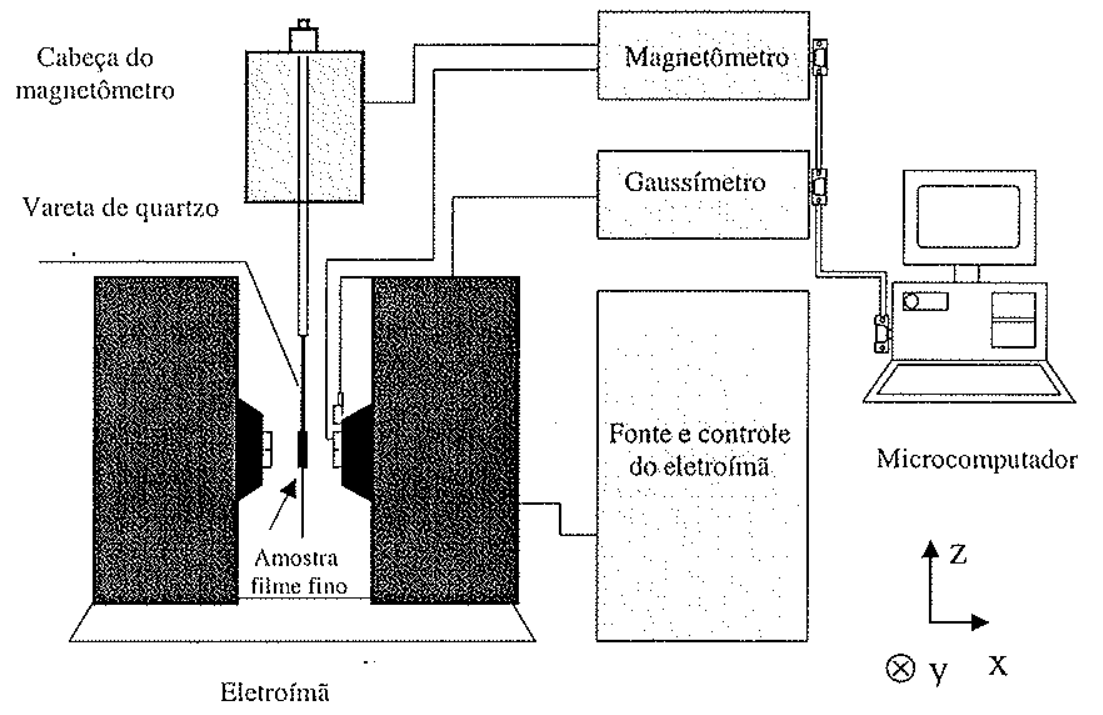

Fig. 4.10 - Diagrama esquemático de um VSM.

tamanho dos grãos, da quantidades de impurezas, dos tipos de defeitos estruturais, dos efeitos de tensões, etc..

Nas medidas de magnetização é importante levar em consideração a presença de campos desmagnetizantes $\left(\mathrm{H}_{D}\right)$. Esses campos atuam no sentido oposto a da magnetização da amostra e têm como fonte os pólos magnéticos que se formam nas extremidades da amostra quando um campo magnético é aplicado. São determinados por $\mathbf{H}_{D}=-\eta \mathrm{M}$, sendo $\eta$ o tensor desmagnetizante, dependente da geometria da amostra $(0 \leq \eta \leq 1$ no S.I. e $0 \leq \eta \leq 4 \pi$ no C.G.S.).

Os termos do tensor $\eta$ podem ser obtidos analiticamente paxa clipsóides. Para outras geometrias o tratamento é bastante complexo. Várias aproximações para um filme fino magnético consideram que todos os elementos do tensor são zero, exceto para a direção perpendicular ao plano do filme [17].

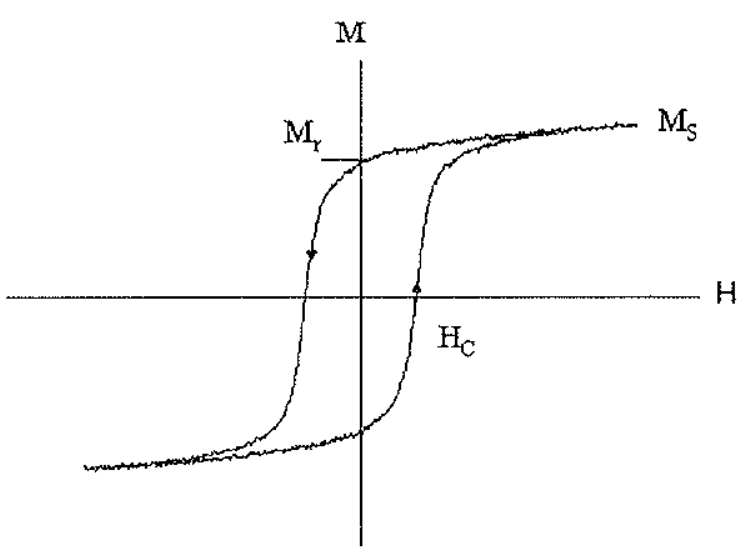

Fig. 4.11 - Típica curva de histerese. 


\subsubsection{Sistema Utilizado e Procedimentos Experimentais}

As propriedades magnéticas dos filmes finos de FePt estudados neste trabalho foram medidas em um Magnetômetro de Amostra Vibrante, marca PAR-EGG (modelo 4500) localizado no Laboratório de Materiais Magnéticos do IFUSP. Este sistema é composto por um microcomputador interfaceado com o eletroímã e com o magnetômetro, o que possibilita que medidas simples, como curva de histerese, possam ser adquiridas automaticamente. A sensibilidade nominal do instrumento é de $10^{-5}$ emu. Os nossos filmes finos possuem magnetização da ordem de $10^{-2}$ a $10^{-4} \mathrm{emu}$. O eletroímã pode atingir um valor máximo de campo magnético aplicado de $20 \mathrm{kOe}$.

A caracterização das propriedades magnéticas de nossas amostras foi realizada com o campo magnético externo aplicado na geometria no plano $\left(\mathbf{H}_{/ /}\right)$e perpendicular ao plano $\left(\mathbf{H}_{\perp}\right)$ da amostra, em temperatura ambiente. Na determinação do valor de campo coercivo o erro estimado é de $4 \%$.

Como já dito anteriormente, a amostra a ser caracterizada é fixada em um porta amostra preso a uma haste rígida não metálica e não magnética no centro geométrico das bobinas sensoras, de modo a estar sujeito a um campo magnético constante, gerado pelo eletroimã. Quando se mede uma curva de histerese, é preciso levar em consideração o sinal da magnetização do porta amostra e do substrato, da ordem de $10^{-4} \mathrm{emu}$. Durante o procedimento experimental, inicialmente fixamos, no porta amostra, um substrato do mesmo tipo e com dimensões parecidas daquele onde o filme a ser analisado foi depositado $\left(\mathrm{SiO}_{2} / \mathrm{Si}(100)\right.$, Si(100) ou MgO (100)), e medimos a curva de histerese deste sistema. Do sinal original obtido nas medidas de curva de histerese das amostras, subtraímos o sinal obtido do sistema porta amostra e substrato, obtendo assim o sinal da amostra.

Os valores de magnetização apresentados não estão normalizados pelo volume do respectivo filme magnético ( $\mathrm{M}$ em função apenas de emu), devido a dificuldade de medição da área dos filmes depositados (amostras muito pequenas com formato irregular) usada na determinação do respectivo volume.

Devido a dificuldade em determinar o exato valor do tensor desmagnetizante $(\eta)$, o qual depende da geometria do corpo magnetizado e só pode ser calculado analiticamente para elipsóides [17], apresentamos as curvas de histerese, medidas na geometria perpendicular ao plano, sem a subtração do campo desmagnetizante, $\mathbf{H}_{D}=-\eta \mathrm{M}$. 


\section{CAPÍTULO 5}

\section{Resultados Experimentais e Discussões}

Iniciamos este capítulo descrevendo as amostras que foram produzidas e caracterizadas em nosso trabalho. Em seguida apresentamos os resultados experimentais obtidos através das medidas de Difração de Raios-X (XRD), Magnetometria de Amostra Vibrante (VSM) e Espectroscopia de Absorção de Raios-X (XAS) das respectivas amostras produzidas. As discussões dos resultados são feitas paralelamente à apresentação dos mesmos. A ordem de apresentação segue aproximadamente a sequiência em que os estudos se desenvolveram. Com o objetivo de se obter uma maior confiabilidade sobre a definição do tipo de fase estrutural presente em cada filme, adotamos o procedimento de analisar em conjunto os dados de XRD e VSM obtidos para cada amostra. Os resultados de XAS são apresentados separadamente, pois representam uma caracterização estrutural fina e complementar de nossas amostras. 


\subsection{Descrição dos Filmes Produzidos}

Conforme já citado anteriormente, os filmes de FePt com composições de aproximadamente 50 at\% $\mathrm{Fe}$ foram preparados através dos métodos de Codeposição e Deposição Alternada de Monocamadas Atômicas (DAM) (ver Capítulo 3). Os filmes foram depositados sobre substratos de $\mathrm{SiO}_{2} / \mathrm{Si}(100)^{1}$, $\mathrm{Si}(100)$ e $\mathrm{MgO}(100)$, com e sem uma camada "buffer" de Pt. Os substratos possuem dimensões de $5 \times 5 \mathrm{~mm}^{2}, 10 \times 5 \mathrm{~mm}^{2}$ e $10 \times 10 \mathrm{~mm}^{2}$. Foram preparadas um total de 46 amostras, divididas em 10 séries. Na tabela 5.1 , são apresentadas características como temperatura do substrato $\left(\mathrm{T}_{\mathrm{S}}\right)$, composição e espessura de filmes de FePt depositados diretamente sobre os substratos utilizados neste trabalho. Na Tabela 5.2, são descritos os filmes de FePt crescidos sobre o "buffer" de Pt. A nomenclatura utilizada para a identificação das amostras é definida como:

$S\left(n^{\circ}\right.$ da série $)($ método de deposição, onde $C=$ codeposição e $D=D A M)-($ letra do alfabeto $)$

Tabela 5.1 - Filmes finos de FePt depositados sobre substratos de $\mathrm{SiO}_{2}, \mathrm{Si}(100)$ e $\mathrm{MgO}(100)$.

\begin{tabular}{|c|c|c|c|}
\hline Amostra & $T_{S}\left({ }^{\circ} \mathrm{C}\right)$ & Composição & Espessura $(\mathrm{nm})$ \\
\hline S1C-A & $\mathrm{RT}$ & $\mathrm{Fe}_{0.53} \mathrm{Pt}_{0.47} / \mathrm{SiO}_{2}$ & 112 \\
\hline S1C-B & 400 & $\mathrm{Fe}_{0.52} \mathrm{Pt}_{0.48} / \mathrm{SiO}_{2}$ & 119 \\
\hline S1C-C & 500 & $\mathrm{Fe}_{0.52} \mathrm{Pt}_{0.48} / \mathrm{SiO}_{2}$ & 113 \\
\hline S1C-D & 600 & $\mathrm{Fe}_{0.52} \mathrm{Pt}_{0.48} / \mathrm{SiO}_{2}$ & 115 \\
\hline S2C-A & 300 & $\mathrm{Fe}_{0.51} \mathrm{Pt}_{0.49} / \mathrm{Si}(100)$ & 104 \\
\hline S2C-B & 400 & $\mathrm{Fe}_{0.51} \mathrm{Pt}_{0.49} / \mathrm{Si}(100)$ & 103 \\
\hline S2C-C & 500 & $\mathrm{Fe}_{0.51} \mathrm{Pt}_{0.49} / \mathrm{Si}(100)$ & 108 \\
\hline S3C-A & RT & $\mathrm{Fe}_{0.53} \mathrm{Pt}_{0.47} / \mathrm{MgO}(100)$ & 112 \\
\hline S3C-B & 400 & $\mathrm{Fe}_{0.52} \mathrm{Pt}_{0.48} / \mathrm{MgO}(100)$ & 119 \\
\hline S3C-C & 500 & $\mathrm{Fe}_{0.52} \mathrm{Pt}_{0.48} / \mathrm{MgO}(100)$ & 113 \\
\hline $\mathrm{S} 3 \mathrm{C}-\mathrm{D}$ & 600 & $\mathrm{Fe}_{0.52} \mathrm{Pt}_{0.48} / \mathrm{MgO}(100)$ & 115 \\
\hline S8D-A & 200 & $\mathrm{Fe}_{0.42} \mathrm{Pt}_{0.48} \mathrm{R}_{0.10} / \mathrm{SiO}_{2}$ & 36 \\
\hline S8D-B & 300 & $\mathrm{Fe}_{0.42} \mathrm{Pt}_{0.48} \mathrm{R}_{0.10} / \mathrm{SiO}_{2}$ & 36 \\
\hline S8D-C & 400 & $\mathrm{Fe}_{0.46} \mathrm{Pt}_{0.48} \mathrm{R}_{0.06} / \mathrm{SiO}_{2}$ & 35 \\
\hline S9D-A & 200 & $\mathrm{Fe}_{0.42} \mathrm{Pt}_{0.48} \mathrm{R}_{0.10} / \mathrm{MgO}(100)$ & 36 \\
\hline S9D-B & 300 & $\mathrm{Fe}_{0.42} \mathrm{Pt}_{0.48} \mathrm{R}_{0.10} / \mathrm{MgO}(100)$ & 36 \\
\hline S9D-C & 400 & $\mathrm{Fe}_{0.46} \mathrm{Pt}_{0.48} \mathrm{R}_{0.06} / \mathrm{MgO}(100)$ & 35 \\
\hline
\end{tabular}

\footnotetext{
${ }^{1}$ Em próximas descrições o termo $\mathrm{SiO}_{2} / \mathrm{Si}(100)$ será simplificado por somente $\mathrm{SiO}_{2}$.
} 
Tabela 5.2 - Filmes finos de FePt depositados sobre substratos de $\mathrm{SiO}_{2}, \mathrm{Si}(100)$ e $\mathrm{MgO}(100)$, com uma camada "buffer" de Pt.

\begin{tabular}{|c|c|c|c|}
\hline$\overline{\text { Amostra }}$ & $\begin{array}{c}T_{S}\left({ }^{\circ} \mathrm{C}\right) \\
(\mathrm{Pt} / \mathrm{FePt})\end{array}$ & $\overline{\text { Composição }}$ & $\begin{array}{c}\text { Espessura (nm) } \\
(\mathrm{FePt} / \mathrm{Pt})\end{array}$ \\
\hline S4C-A & $300 / 300$ & $\mathrm{Fe}_{0.49} \mathrm{Pt}_{0.51} / \mathrm{Pt} / \mathrm{SiO}_{2}$ & $99 / 57$ \\
\hline S4C-B & $400 / 400$ & $\mathrm{Fe}_{0.48} \mathrm{Pt}_{0.52} / \mathrm{Pt} / \mathrm{SiO}_{2}$ & $98 / 57$ \\
\hline $\mathrm{S} 4 \mathrm{C}-\mathrm{C}$ & $500 / 500$ & $\mathrm{Fe}_{0.49} \mathrm{Pt}_{0.5 \mathrm{l}} / \mathrm{Pt} / \mathrm{SiO}_{2}$ & $97 / 57$ \\
\hline S4C-D & $600 / 600$ & $\mathrm{Fe}_{0.49} \mathrm{Pt}_{0.51} / \mathrm{Pt} / \mathrm{SiO}_{2}$ & $97 / 57$ \\
\hline S5C-A & $300 / 300$ & $\mathrm{Fe}_{0.5 \mathrm{l}} \mathrm{Pt}_{0.49} / \mathrm{Pt}_{0.92} \mathrm{Si}_{0.08} / \mathrm{Si}(100)$ & $104 / 70$ \\
\hline S5C-B & $400 / 400$ & $\mathrm{Fe}_{0.5 \mathrm{t}} \mathrm{Pt}_{0.49} / \mathrm{Pt}_{0.90} \mathrm{Si}_{0.10} / \mathrm{Si}(100)$ & $105.1 / 76$ \\
\hline $\mathrm{S} 5 \mathrm{C}-\mathrm{C}$ & $500 / 500$ & $\mathrm{Fe}_{0.51} \mathrm{Pt}_{0.49} / \mathrm{Pt}_{0.55} \mathrm{Si}_{0.45} / \mathrm{Si}(100)$ & $103 / 201$ \\
\hline $\mathrm{S} 6 \mathrm{C}-\mathrm{A}$ & $300 / 300$ & $\mathrm{Fe}_{0.51} \mathrm{Pt}_{0.49} / \mathrm{Pt} / \mathrm{MgO}(100)$ & $104 / 70$ \\
\hline S6C-B & $400 / 400$ & $\mathrm{Fe}_{0.51} \mathrm{Pt}_{0.49} / \mathrm{Pt} / \mathrm{MgO}(100)$ & $105.1 / 76$ \\
\hline $\mathrm{S} 6 \mathrm{C}-\mathrm{C}$ & $500 / 500$ & $\mathrm{Fe}_{0.51} \mathrm{Pt}_{0.49} / \mathrm{Pt} / \mathrm{MgO}(100)$ & $103.5 / 70$ \\
\hline S6C-D & $600 / 600$ & $\mathrm{Fe}_{0.51} \mathrm{Pt}_{0.49} / \mathrm{Pt} / \mathrm{MgO}(100)$ & $103.5 / 70$ \\
\hline S7C-A & $500 / 200$ & $\mathrm{Fe}_{0.48} \mathrm{Pt}_{0.47} \mathrm{R}_{0.05} / \mathrm{Pt} / \mathrm{MgO}(100)$ & $36 / 50$ \\
\hline S7C-B & $300 / 200$ & $\mathrm{Fe}_{0.48} \mathrm{Pt}_{0.47} \mathrm{R}_{0.05} / \mathrm{Pt} / \mathrm{MgO}(100)$ & $34 / 50$ \\
\hline S7C-C & $200 / 200$ & $\mathrm{Fe}_{0.48} \mathrm{Pt}_{0.47} \mathrm{R}_{0.05} / \mathrm{Pt} / \mathrm{MgO}(100)$ & $34 / 50$ \\
\hline S7C-D & $500 / 300$ & $\mathrm{Fe}_{0.48} \mathrm{Pt}_{0.47} \mathrm{R}_{0.05} / \mathrm{Pt} / \mathrm{MgO}(100)$ & $34 / 50$ \\
\hline S7C-E & $300 / 300$ & $\mathrm{Fe}_{0.46} \mathrm{Pt}_{0.49} \mathrm{R}_{0.06} / \mathrm{Pt} / \mathrm{MgO}(100)$ & $34 / 50$ \\
\hline S7C-F & $200 / 300$ & $\mathrm{Fe}_{0.48} \mathrm{Pt}_{0.48} \mathrm{R}_{0.04} / \mathrm{Pt} / \mathrm{MgO}(100)$ & $34 / 50$ \\
\hline $\mathrm{S} 7 \mathrm{C}-\mathrm{G}$ & $200 / 500$ & $\mathrm{Fe}_{0.47} \mathrm{Pt}_{0.47} \mathrm{R}_{0.06} / \mathrm{Pt} / \mathrm{MgO}(100)$ & $32 / 50$ \\
\hline S7C-H & $300 / 500$ & $\mathrm{Fe}_{0.47} \mathrm{Pt}_{0.47} \mathrm{R}_{0.06} / \mathrm{Pt} / \mathrm{MgO}(100)$ & $32 / 50$ \\
\hline S7C-I & $500 / 500$ & $\mathrm{Fe}_{0.47} \mathrm{Pt}_{0.47} \mathrm{R}_{0.06} / \mathrm{Pt} / \mathrm{MgO}(100)$ & $32 / 50$ \\
\hline S8D-D & $200 / 200$ & $\mathrm{Fe}_{0.45} \mathrm{Pt}_{0.47} \mathrm{R}_{0.08} / \mathrm{Pt} / \mathrm{SiO}_{2}$ & $35 / 65$ \\
\hline S8D-E & $300 / 300$ & $\mathrm{Fe}_{0.42} \mathrm{Pt}_{0.48} \mathrm{R}_{0.10} / \mathrm{Pt} / \mathrm{SiO}_{2}$ & $36 / 66$ \\
\hline S8D-F & $400 / 400$ & $\mathrm{Fe}_{0.46} \mathrm{Pt}_{0.48} \mathrm{R}_{0.06} / \mathrm{Pt} / \mathrm{SiO}_{2}$ & $35 / 65$ \\
\hline S9D-D & $200 / 200$ & $\mathrm{Fe}_{0.45} \mathrm{Pt}_{0.47} \mathrm{R}_{0.08} / \mathrm{Pt} / \mathrm{MgO}(100)$ & $35 / 65$ \\
\hline S9D-E & $300 / 300$ & $\mathrm{Fe}_{0.42} \mathrm{Pt}_{0.48} \mathrm{R}_{0.10} / \mathrm{Pt} / \mathrm{MgO}(100)$ & $36 / 66$ \\
\hline S9D-F & $400 / 400$ & $\mathrm{Fe}_{0.46} \mathrm{Pt}_{0.48} \mathrm{R}_{0.06} / \mathrm{Pt} / \mathrm{MgO}(100)$ & $35 / 65$ \\
\hline S10D-A & $500 / 200$ & $\mathrm{Fe}_{0.45} \mathrm{Pt}_{0.46} \mathrm{R}_{0.09} / \mathrm{Pt} / \mathrm{MgO}(100)$ & $37 / 65$ \\
\hline S10D-B & $500 / 300$ & $\mathrm{Fe}_{0.45} \mathrm{Pt}_{0.46} \mathrm{R}_{0.09} / \mathrm{Pt} / \mathrm{MgO}(100)$ & $37 / 65$ \\
\hline S10D-C & $500 / 400$ & $\mathrm{Fe}_{0.45} \mathrm{Pt}_{0.46} \mathrm{R}_{0.09} / \mathrm{Pt} / \mathrm{MgO}(100)$ & $37 / 65$ \\
\hline
\end{tabular}

As primeiras séries são de amostras preparadas por codeposição, pois a utilização do método de DAM tornou-se possível somente em etapas posteriores, após o desenvolvimento da instrumentação.

Os primeiros filmes de FePt foram preparados com espessuras maiores (de 97 a 119 nm). Essa faixa de espessura foi escolhida ao acaso, pois a proposta inicial não era estudar a 
influência da espessura mas, sim, do valor de $\mathrm{T}_{S}$ e tipo de substrato sobre as propriedades estruturais e magnéticas dos filmes. Com o andamento do trabalho, através dos resultados obtidos, resolvemos trabalhar na preparação de filmes menos espessos (de 32 a $37 \mathrm{~nm}$ ) e estudar os efeitos produzidos. Conforme será apresentado mais adiante, o alcance do efeito de um crescimento "epitaxial" induzido do filme sobre um substrato é fortemente dependente da espessura do mesmo.

Os valores de composição obtidos para os filmes de FePt menos espessos apresentam uma considerável quantidade de contaminantes na amostra, que podem ter sido adquiridos durante a deposição ou através do posterior contato com o ambiente.

Na Tabela 5.2, é possível verificar, para os filmes de FePt depositados sobre Si(100) com o "buffer" de Pt (série 5), a presença de Si misturado a Pt. Este fato é resultante de uma forte interdifusão entre os átomos de Pt com os do substrato, conforme será melhor discutido mais adiante.

\subsection{Filmes Preparados pelo Método de Codeposição}

A partir deste momento serão apresentados os resultados experimentais obtidos para os filmes de FePt preparados por codeposição. Na primeira seção, somente os filmes de FePt depositados diretamente sobre o substrato serão descritos. Nas seções seguintes, focalizaremos nossa atenção nos resultados obtidos com a utilização do "buffer" de Pt.

\subsubsection{Filmes de FePt depositados diretamente sobre o substrato}

Na primeira etapa do trabalho, foram preparados e caracterizados filmes de FePt depositados sobre substratos amorfos de $\mathrm{SiO}_{2}$ em variados valores de $\mathrm{T}_{\mathrm{S}}$. Com a utilização deste tipo de substrato tivemos a possibilidade de estudar, de maneira isolada, a influência do valor de $\mathrm{T}_{S}$ sobre o processo de ordenamento do filme.

Na Figura 5.1 são apresentados difratogramas de XRD e curvas de histerese das amostras $\mathrm{FePt} / \mathrm{SiO}_{2}$ (série 1). Para os filmes crescidos até $400^{\circ} \mathrm{C}$, a existência de um único pico de difração FePt(111), nos dados de XRD, a presença de anisotropia magnética no plano e a baixa coercividade (em ambas as geometrias), conforme pode ser verificado pelas curvas de histerese (Fig. 5.1(b)), indicam a presença de uma fase estrutural FCC(111) no filme. A forma das curvas de histerese desses filmes mostram que a rotação de paredes de 

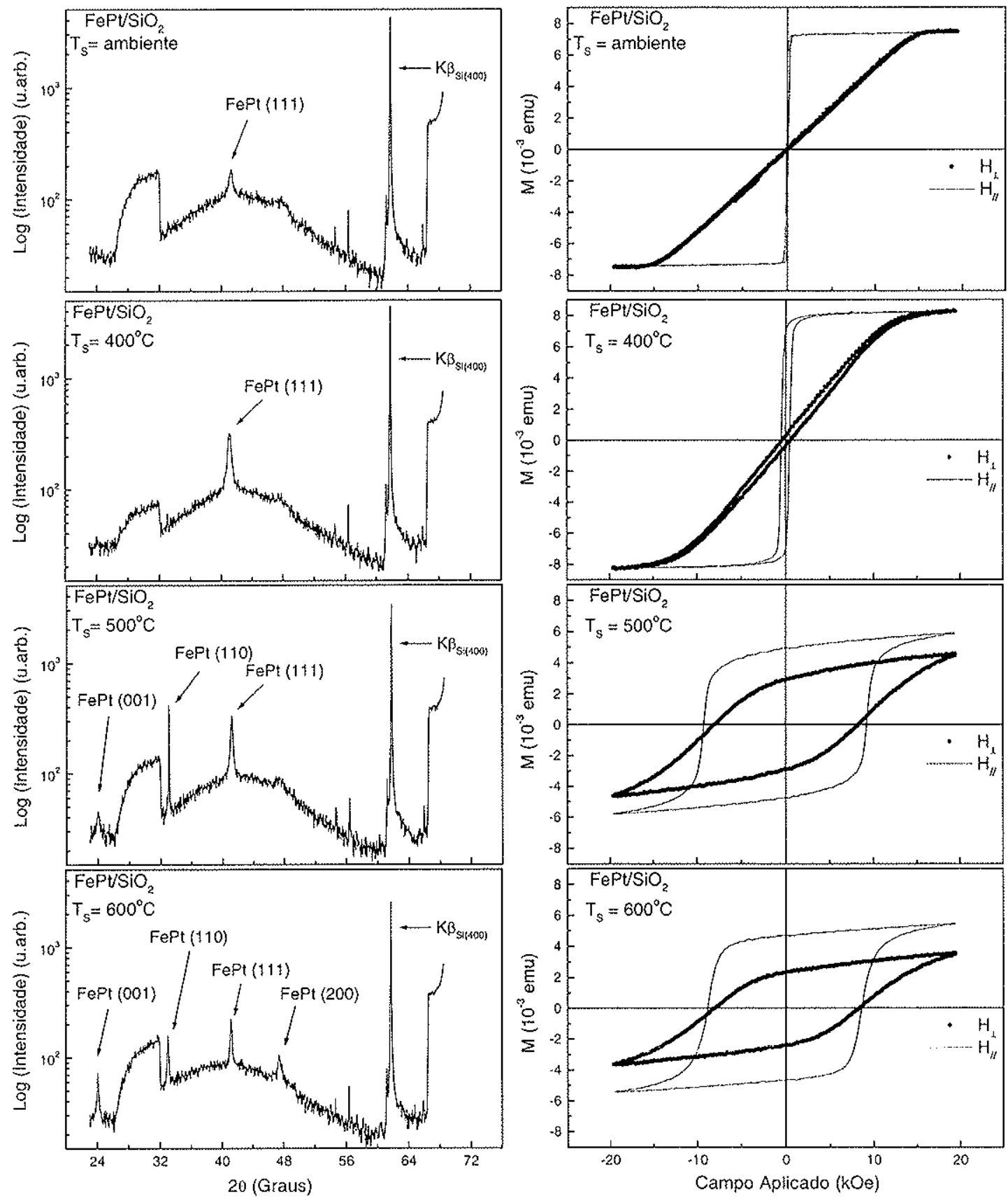

a)

b)

Fig. 5.1 - (a) Difratogramas de XRD e (b) curvas de histerese de filmes de FePt depositados sobre substratos de $\mathrm{SiO}_{2}$.

domínio é o mecanismo dominante para a reversão da magnetização. Porém, para $T_{S} \geq 500^{\circ} \mathrm{C}$, observa-se que além do pico de difração $\mathrm{FePt}(111)$, posicionado em $2 \theta=41,05^{\circ}$, há também a presença de picos de difração FePt(001), FePt(110) e FePt(200). Estes picos de difração são indexados como sendo pertencentes a estrutura cristalina FCT (ver fichas JCPDS - Apêndice I) e indicam a existência de uma mistura de texturas no filme. As medidas magnéticas mostram um grande crescimento da área interna das curvas de histerese, o que decorre de perdas energéticas durante o processo de magnetização. A área da histerese está relacionada a 

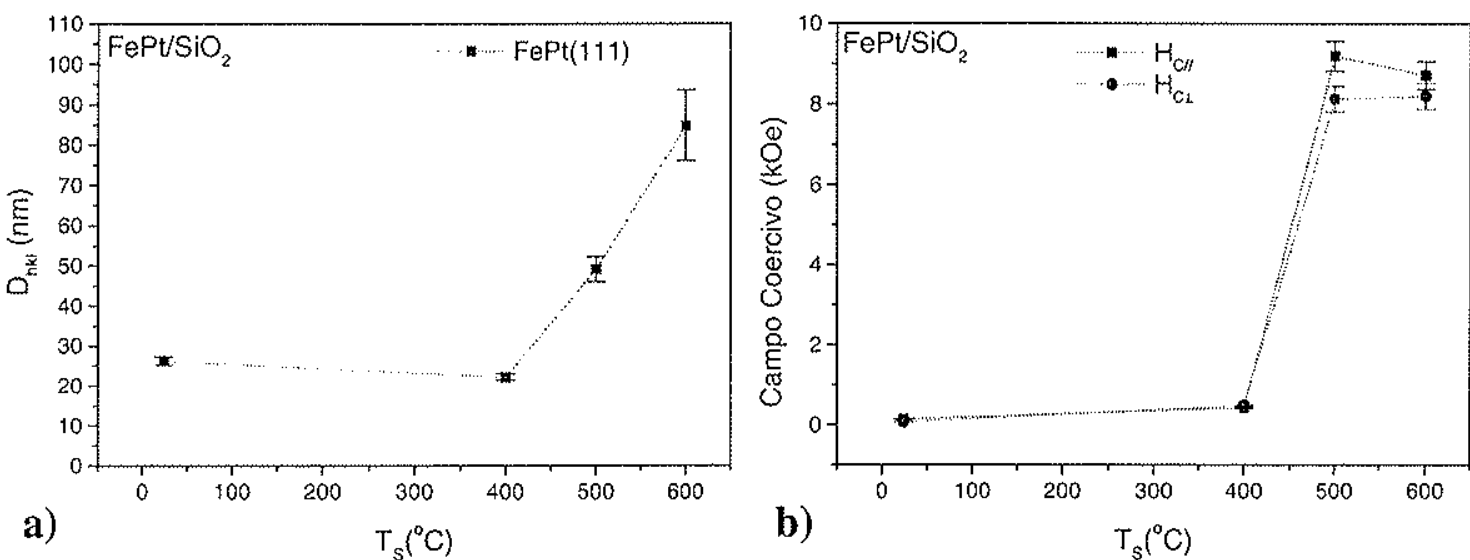

Fig. 5.2 - Gráficos com (a) valores de tamanho médio do grão cristalino $\left(D_{h k l}\right)$, correspondente ao plano de difração $\mathrm{FePt}(111)$, e (b) valores de campo coercivo $\left(\mathrm{H}_{\mathrm{C}}\right)$, em função da temperatura de deposição $\left(\mathrm{T}_{S}\right)$, dos filmes finos de $\mathrm{FePt}$ depositados sobre substratos de $\mathrm{SiO}_{2}$.

estas perdas. A magnetização não alcança a saturação com um campo magnético aplicado de 20 kOe (limite máximo permitido ao eletroímã do VSM utilizado). Na Figura 5.2(b), pode-se verificar que a coercividade cresce bruscamente acima de $400^{\circ} \mathrm{C}$, sendo os valores nas duas geometrias muito próximos. Para esses filmes, a alta coercividade e a pequena diferença entre os valores nas duas geometrias é explicado como sendo devido a mistura de texturas. Valores de tamanho médio do grão cristalino $\left(D_{h k l}\right)$ para esses filmes, calculados pelo pico FePt(111), são apresentados em função de $T_{S}$ na Figura 5.2(a). Pode-se verificar que a partir de $T_{S}=$ $400^{\circ} \mathrm{C}$, uma mudança no comportamento do valor de $D_{h k l}$ indica a presença de mudança de fase estrutural nos filmes. Em $600^{\circ} \mathrm{C}$, o maior valor de $D_{h k l}$ revela a presença de um filme com melhor coerência cristalina. Estes resultados mostram que os efeitos de $T_{S}$ possibilitam a formação de uma estrutura $\mathrm{FCT}$ na camada $\mathrm{FePt}$ em deposições realizadas a partir de $500^{\circ} \mathrm{C}$, porém, com uma mistura de texturas. Para a obtenção de um filme de FePt com uma estrutura FCT e dominante textura [001] (fase estrutural FCT(001)), desprezando efeitos de um crescimento induzido, é necessário a preparação de filmes em temperaturas mais altas.

Para filmes de FePt depositados sobre substratos monocristalinos de Si(100) (série 2), os resultados de XRD e VSM mostram um comportamento semelhante ao dos filmes depositados sobre $\mathrm{SiO}_{2}$. Na Figura 5.3 são apresentados difratogramas de XRD e curvas de histerese obtidas para esses filmes. Pode-se verificar, para $T_{S} \leq 400^{\circ} \mathrm{C}$, a presença de somente um pico de difração $\mathrm{FePt}(111)$, em $2 \theta=40.9^{\circ}$, e a presença de anisotropia magnética no plano e baixos valores de coercividade (nas duas geometrias), o que caracteriza a presença da fase estrutural $\mathrm{FCC}(111)$. Para $\mathrm{T}_{\mathrm{S}}=500^{\circ} \mathrm{C}$, a presença de picos de difração FePt(001), FePt(110) e (200), além do pico FePt(111) em $20=41.09^{\circ}$, indicam a presença de 

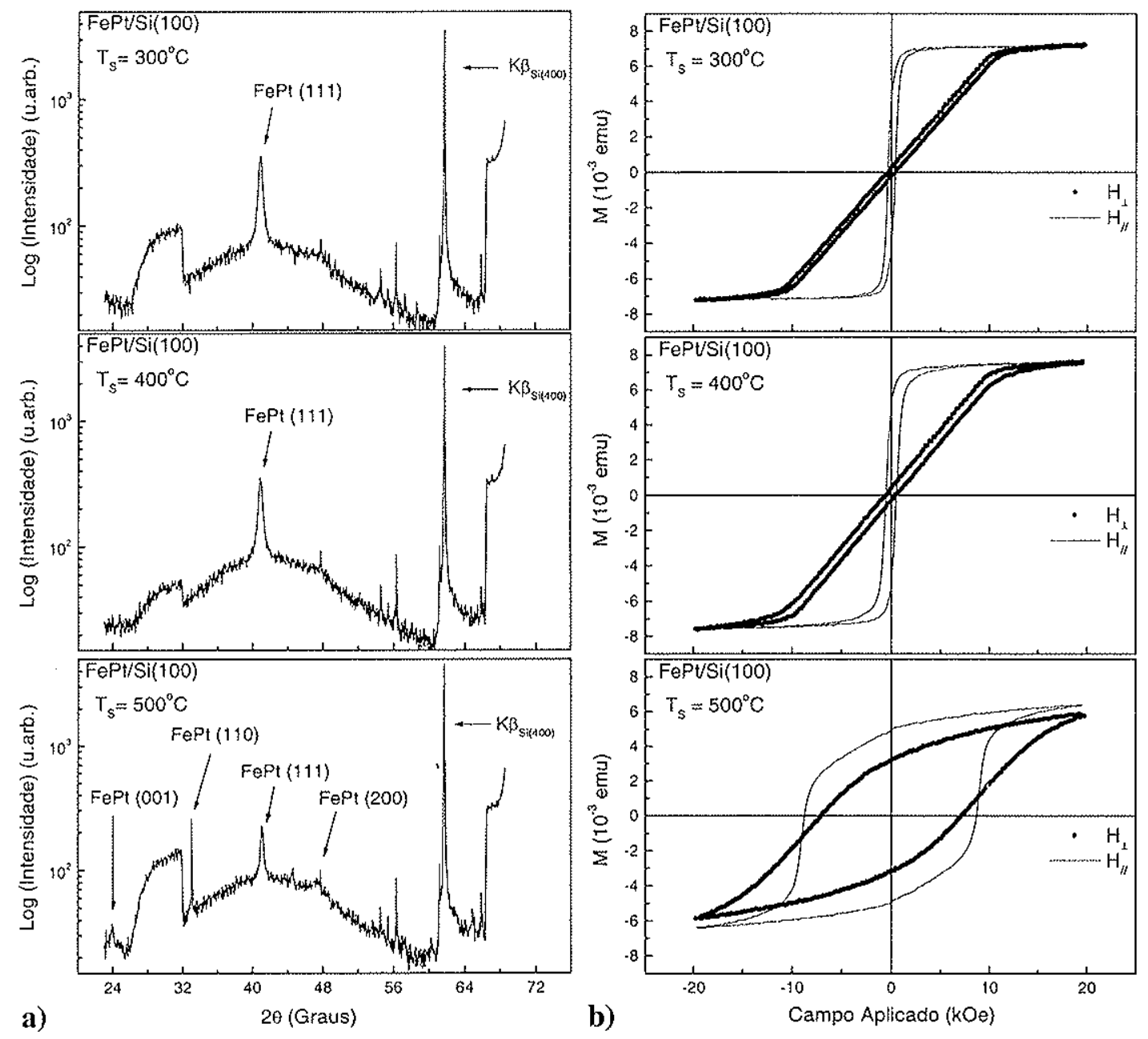

Fig. 5.3 - (a) Difratogramas de XRD e (b) curvas de histerese de filmes de FePt depositados sobre substratos de $\mathrm{Si}(100)$.

uma estrutura cristalina FCT e uma mistura de texturas no filme. As medidas magnéticas mostram a presença de um aumento da energia de anisotropia magnética e um brusco aumento da coercividade (ver Fig.5.4 (b)) em ambas geometrias, interpretados como sendo devido a uma mistura de texturas no filme. Para estes filmes o valor de $D_{h k l}$ cresce de $17 \mathrm{~nm}$ em $\mathrm{T}_{S}=300^{\circ} \mathrm{C}$ para $28 \mathrm{~nm}$ em $\mathrm{T}_{\mathrm{S}}=500^{\circ} \mathrm{C}$ (ver Fig. 5.4(a)), indicando melhor cristalinidade com o aumento de $\mathrm{T}_{\mathrm{S}}$.

A semelhança entre os resultados obtidos com o Si(100) quando comparados com a deposição sobre $\mathrm{SiO}_{2}$ é interpretada em termos do tipo de estrutura cristalina do respectivo substrato. O substrato de Si possui uma estrutura cristalina cúbica de face centrada (tipo diamante). Essa estrutura tipo diamante possui caracteríticas que a diferenciam muito da estrutura cúbica da liga FePt. Portanto, a incompatibilidade estrutural impede que o respectivo substrato exerça um crescimento "epitaxial" induzido no filme, sobrando apenas os efeitos devido a temperatura, como no caso do $\mathrm{SiO}_{2}$. 


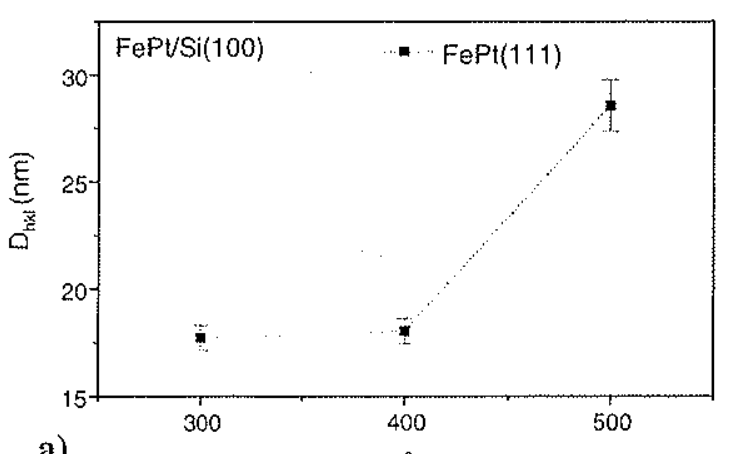

a)

$\mathrm{T}_{\mathrm{S}}\left({ }^{\circ} \mathrm{C}\right)$

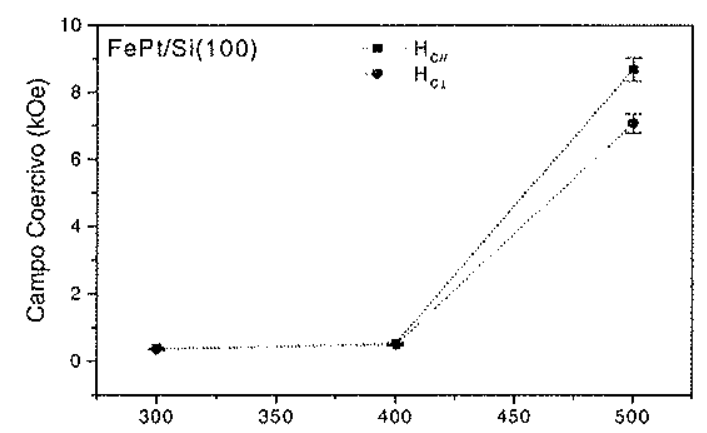

b)

Fig. 5.4 - Gráficos com (a) valores médios de tamanho de grão cristalino $\left(\mathrm{D}_{\mathrm{bkl}}\right)$, correspondente ao plano de difração FePt(111), e (b) valores de campo coercivo $\left(\mathrm{H}_{\mathrm{C}}\right)$, em função da temperatura de deposição $\left(\mathrm{T}_{\mathrm{S}}\right)$, dos filmes finos de $\mathrm{FePt}$ depositados sobre substratos de $\mathrm{Si}(100)$.

Em uma nova condição, filmes de FePt foram depositados sobre substratos monocristalinos de $\mathrm{MgO}$ (100) em variados valores de $\mathrm{T}_{S}$ (série 3). As medidas de XRD e curvas de histerese dessas amostras são apresentadas na Figura 5.5. Para o filme depositado em temperatura ambiente, os dados de XRD mostram a presença de somente um pico FePt(111), de pequena intensidade, o qual indica a presença de baixo grau de cristalinidade no filme. A forma das curvas de histerese desse filme (Fig. 5.5(b)) mostram a presença de anisotropia magnética no plano e muito baixa coercividade nas duas geometrias. Esses resultados caracterizam a presença de uma fase estrutural $\mathrm{FCC}(111)$ no filme. Para $\mathrm{T}_{\mathrm{S}}=$ $400^{\circ} \mathrm{C}$, somente um único pico de difração $\mathrm{FePt}(200)\left(2 \theta=47,50^{\circ}\right)$ é visualizado, sendo indexado como pertencente a estrutura FCC. As curvas de histerese mostram a presença de anisotropia planar e coercividade no plano $\left(H c_{/ /}\right)$de $\approx 0.54 \mathrm{kOe}$. Na geometria perpendicular, o campo magnético aplicado de $20 \mathrm{kOe}$ não é suficiente para alcançar uma condição de saturação da magnetização. A presença de somente um pico de difração FePt(200) revela que esse filme é fortemente texturizado na direção [100]. No caso do filme depositado em $\mathrm{T}_{S}=$ $500^{\circ} \mathrm{C}$, um decréscimo de intensidade do pico FePt(200) é observado através do respectivo difratograma de XRD. As curvas de histerese revelam aumento da sua energia de anisotropia magnética e também um grande aumento da coercividade (valores de $H c_{/ /}=4.3 \mathrm{kOe}$ e $H c_{\perp}=$ 2.5 kOe medidos com magnetização da amostra fora da condição de saturação), indicando que os fatores que influenciam a coercividade são maiores no plano da amostra. Para esse filme, o aumento da coercividade esta relacionado com a presença de uma alta densidade de defeitos estruturais no filme, os quais podem ser gerados por uma mudança de fase estrutural. Defeitos estruturais em filmes magnéticos causam um travamento ("pinning") do movimento das paredes de domínio. Em $\mathrm{T}_{\mathrm{S}}=600^{\circ} \mathrm{C}$, é possível visualizar através dos dados de XRD a 
presença de picos de difração FePt(001), (002) e (003), de alta intensidade, além de um pico $\mathrm{FePt}(200)$ de muito baixa intensidade. Os picos FePt(001) e (003) são conhecidos como picos de super-rede e caracterizam a presença de uma fase estrutural predominante FCT(001) no filme, apesar de que a presença do pico FePt(200) indica que ainda uma pequena parcela de cristalitos possuem a fase $\mathrm{FCC}(100)$. Para este filme, o grau de ordenamento químico de longo alcance $(S)$ é de 0,84 , valor este próximo de um perfeito ordenamento químico. As respectivas curvas de histerese mostram que na geometria perpendicular a magnetização alcança a saturação em baixo campo magnético aplicado, o mesmo não acontecendo com a medida realizada na geometria no plano. Este resultado revela a presença de anisotropia magnética perpendicular e coercividade $\left(H c_{\perp}\right)$ de $1,0 \mathrm{kOe}$, os quais são correlacionados com a formação da fase estrutural quimicamente ordenada FCT(001). A presença de coercividade no plano é um indicativo da presença de cristalitos ainda orientados no plano do filme. Os valores de tamanho médio do grão variam de $22 \mathrm{~nm}\left(\mathrm{~T}_{\mathrm{S}}=400^{\circ} \mathrm{C}\right)$ para $51,8 \mathrm{~nm}\left(\mathrm{~T}_{\mathrm{S}}=600^{\circ} \mathrm{C}\right)$, o que mostra que o filme depositado em temperatura mais alta possui melhor cristalinidade.

Os bons resultados obtidos com a utilização do $\mathrm{MgO}$ são atribuídos as suas características estruturais, favoráveis para forçar um crescimento "epitaxial"2 induzido do filme de FePt com o tipo de fase estrutural desejada. O MgO é termicamente estável em altas temperaturas (ponto de fusão próximo de $3000^{\circ} \mathrm{C}$ ) e possui uma estrutura cristalina cúbica de face centrada (tipo $\mathrm{B} 1-\mathrm{NaCl}$ ), com um parâmetro de rede $(a)$ de $0.4213 \mathrm{~nm}[50,51]$. A diferença entre os valores de parâmetro de rede da liga FePt FCC e do MgO é de aproximadamente $9.4 \%$. Portanto, o crescimento da camada FePt sobre o MgO, por codeposição, gera a tendência de uma combinação entre os parâmetros de rede da liga e do $\mathrm{MgO}$, fazendo com que o filme cresça correlacionado com a estrutura do substrato. Com deposições em $T_{S}$ ambiente, o grau de cristalinidade é baixo e os efeitos de um crescimento induzido sobre os poucos cristalitos que se formam são mínimos. Devido a minimização da energia livre de superfície, os poucos cristalitos se formam com uma fase estrutural FCC(111). Em moderados valores de $\mathrm{T}_{S}$, a estrutura FCC ainda predomina, porém uma textura [100] é induzida. Em altos valores de $\mathrm{T}_{S}$ (maior mobilidade atômica) os átomos da

\footnotetext{
${ }^{2} \mathrm{O}$ termo "epitaxial" têm sido utilizado sempre que citamos que o filme sofreu um processo de um crescimento induzido. Porém, o crescimento de filmes finos via uma "epitaxia" é característico de técnicas de preparação que permitem um alto controle do processo de deposição (sistemas que operam em UHV, ex.: MBE, etc.), onde camada por camada atômica de um material é depositada sobre um substrato, formando um filme uniforme monocristalino. Estas técnicas são largamente utilizadas para preparação de filmes semicondutores. Como no nosso trabalho utilizamos um sistema de "Sputtering", é importante frisar que o processo de um crescimento induzido dos filmes ocorre via uma "epitaxia" granular.
} 

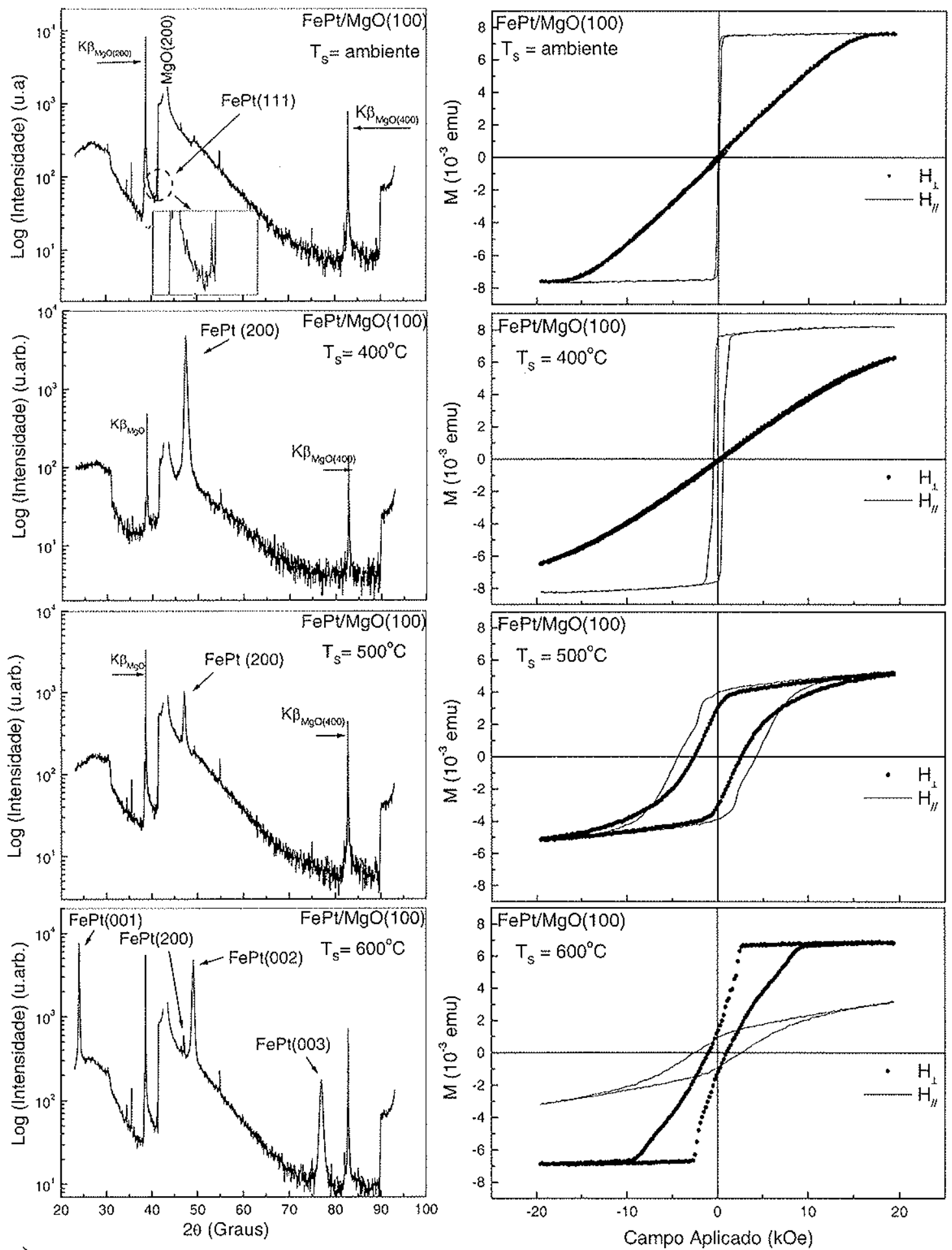

a)

b)

Fig. 5.5 - (a) Difratogramas de XRD e (b) curvas de histerese de filmes de FePt depositados sobre substratos de $\mathrm{MgO}(100)$.

camada FePt tendem a se organizar e uma melhor combinação dos mesmos com a estrutura do substrato torna-se possível, possibilitando a formação de cristalitos com uma estrutura quimicamente ordenada FCT e textura [001]. Porém, mesmo em $\mathrm{T}_{\mathrm{S}}=600^{\circ} \mathrm{C}$, a presença de 
um filme de FePt com uma única fase estrutural FCT(001) (perfeito ordenamento químico) ainda não foi possível de ser obtida. É provável que somente com deposições em temperaturas ainda maiores isto seja possível.

Devido ao fato dos átomos de Fe e Pt possuírem raios atômicos diferentes $\left(\mathrm{R}_{\mathrm{Pt}}>\mathrm{R}_{\mathrm{Fe}}\right)$, a estrutura ordenada FePt FCT é representada como uma distorção tetragonal, onde o eixo-c é o eixo de tamanho reduzido. Os parâmetros de rede da estrutura FePt FCT são $a=b=0.3852$ e $c=0.3728 \mathrm{~nm}$.

Como conclusão desta primeira parte de resultados experimentais e discussões, apresentamos na Tabela 5.3 as principais propriedades dos filmes analisados. A magnetização de saturação é de aproximadamente $1070 \mathrm{emu} / \mathrm{cm}^{3}$, para os filmes com anisotropia magnética no plano (estrutura FCC). Para a maioria dos casos, a saturação da magnetização não é alcançada com um campo magnético aplicado de $20 \mathrm{kOe}$. Os campos coercivos medidos nessa condição são grifados com um (*), na Tabela 5.3.

Tabela 5.3 - Propriedades estruturais e magnéticas dos filmes de FePt depositados sobre substratos de $\mathrm{SiO}_{2}, \mathrm{Si}(100)$ e $\mathrm{MgO}(100)$

\begin{tabular}{|c|c|c|c|c|c|c|}
\hline Amostra & Composição & $\begin{array}{c}T_{S} \\
\left({ }^{\circ} \mathrm{C}\right)\end{array}$ & $\begin{array}{c}\text { Estrutura } \\
\text { predominante }\end{array}$ & $\begin{array}{c}\text { Textura } \\
\text { Principal }\end{array}$ & $\begin{array}{c}H_{C / /} \\
(k O e)\end{array}$ & $\begin{array}{c}H_{C \perp} \\
(k O e)\end{array}$ \\
\hline S1C-A & $\mathrm{Fe}_{0.53} \mathrm{Pt}_{0.47} / \mathrm{SiO}_{2}$ & RT & $\mathrm{FCC}$ & {$[111]$} & 0,14 & 0,07 \\
\hline S1C-B & $\mathrm{Fe}_{0.52} \mathrm{Pt}_{0.48} / \mathrm{SiO}_{2}$ & 400 & FCC & [111] & 0,42 & 0,49 \\
\hline S1C-C & $\mathrm{Fe}_{0.52} \mathrm{Pt}_{0.48} / \mathrm{SiO}_{2}$ & 500 & FCT & $\begin{array}{c}{[001],[110] \mathrm{e}} \\
{[111]}\end{array}$ & $9,20^{*}$ & $8,13^{*}$ \\
\hline S1C-D & $\mathrm{Fe}_{0.52} \mathrm{Pt}_{0.48} / \mathrm{SiO}_{2}$ & 600 & FCT & $\begin{array}{l}{[001],[110]} \\
{[111] \mathrm{e}[100]}\end{array}$ & $8,71^{*}$ & $8,20^{*}$ \\
\hline $\mathrm{S} 2 \mathrm{C}-\mathrm{A}$ & $\mathrm{Fe}_{0.51} \mathrm{Pt}_{0.49} / \mathrm{Si}(100)$ & 300 & FCC & {$[111]$} & 0,38 & 0,34 \\
\hline S2C-B & $\mathrm{Fe}_{0.51} \mathrm{Pt}_{0.49} / \mathrm{Si}(100)$ & 400 & $\mathrm{FCC}$ & [111] & 0,53 & 0,47 \\
\hline $\mathrm{S} 2 \mathrm{C}-\mathrm{C}$ & $\mathrm{Fe}_{0.51} \mathrm{Pt}_{0.49} / \mathrm{Si}(100)$ & 500 & FCT & $\begin{array}{l}{[001],[110]} \\
{[111] \text { e }[100]}\end{array}$ & $8,69^{*}$ & $7,07^{*}$ \\
\hline S3C-A & $\mathrm{Fe}_{0.53} \mathrm{Pt}_{0.47} / \mathrm{MgO}(100)$ & $\mathrm{RT}$ & $\mathrm{FCC}$ & {$[111]$} & 0,10 & 0,28 \\
\hline S3C-B & $\mathrm{Fe}_{0.52} \mathrm{Pt}_{0.48} / \mathrm{MgO}(100)$ & 400 & $\mathrm{FCC}$ & {$[100]$} & 0,54 & $0,08^{*}$ \\
\hline S3C-C & $\mathrm{Fe}_{0.52} \mathrm{Pt}_{0.48} / \mathrm{MgO}(100)$ & 500 & FCC/FCT & {$[100]$} & $4,30^{*}$ & $2,58^{*}$ \\
\hline S3C-D & $\mathrm{Fe}_{0.52} \mathrm{Pt}_{0.48} / \mathrm{MgO}(100)$ & 600 & FCT & {$[001]$} & $2,57^{*}$ & 1,00 \\
\hline
\end{tabular}

(*) Valores obtidos em condiçōes onde a magnetização não alcança a saturação com um campo magnético aplicado de $20 \mathrm{kOe}$.

$\mathrm{RT}=$ temperatura ambiente 


\subsubsection{Filmes de FePt depositados sobre um "buffer" de Pt}

Visando obter melhores condições para a preparação de filmes de $\mathrm{FePt}$, resolvemos estudar a influência de um "buffer" de Pt, pré-depositada sobre os substratos de $\mathrm{SiO}_{2}$, $\mathrm{Si}(100)$ e $\mathrm{MgO}(100)$, exerce sobre as propriedades estruturais e magnéticas de um filme de FePt crescido sobre o mesmo. Um buffer é uma camada de um material cujas propriedades estruturais são influenciadas pelo substrato sobre o qual ele é depositado, diferentemente de uma "underlayer" onde as respectivas propriedades estruturais são características do próprio material. Essas características que o "buffer" recebe do substrato são, em muitas situações, adequadas para induzir uma desejada fase estrutural em um filme crescido sobre ele.

Na preparação das amostras, o "buffer" de Pt e a camada FePt foram depositados sob o mesmo valor de $\mathrm{T}_{\mathrm{S}}$. Filmes puros de $\mathrm{Pt}$ também foram preparados, utilizando-se de condições de deposição semelhantes às dos filmes de FePt/Pt. Deste modo, cada conjunto de filmes FePt/Pt e Pt pertencem a mesma série. Com este procedimento buscamos estudar de maneira mais precisa as propriedades estruturais dessa camada intermediária. Na Tabela 5.4 são descritos os filmes de $\mathrm{Pt}$ crescidos sobre substratos de $\mathrm{SiO}_{2}, \mathrm{Si}(100)$ e $\mathrm{MgO}(100)$. A nomenclatura utilizada para a identificação das amostras é definida como:

\section{$S\left(n^{o}\right.$ da série)(símbolo do elemento)-(letra do alfabeto)}

$\mathrm{Na}$ escolha da espessura do "buffer", nos baseamos nos estudos desenvolvidos por Caro et al. [52], os quais demonstraram que a formação de um filme contínuo de Pt somente é possível a partir de uma espessura de $45 \mathrm{~nm}$. Portanto, não nos preocupamos de início com uma otimização da espessura, apenas adotamos o procedimento de utilizar um valor acima de $45 \mathrm{~nm}$.

Tabela 5.4 - Filmes de platina (Pt) depositados sobre substratos de $\mathrm{SiO}_{2}$, $\mathrm{Si}(100)$ e $\mathrm{MgO}(100)$.

\begin{tabular}{cccc}
\hline \multicolumn{1}{c}{ Série } & $T_{S}\left({ }^{\circ} \mathrm{C}\right)$ & Composicão & Espessura $(\mathrm{nm})$ \\
\hline S4Pt-A & 300 & $\mathrm{Pt} / \mathrm{SiO}_{2}$ & 55 \\
\hline $\mathrm{S} 4 \mathrm{Pt}-\mathrm{B}$ & 400 & $\mathrm{Pt} / \mathrm{SiO}_{2}$ & 58 \\
\hline $\mathrm{S} 4 \mathrm{Pt}-\mathrm{C}$ & 500 & $\mathrm{Pt} / \mathrm{SiO}_{2}$ & 55 \\
\hline S4Pt -D & 600 & $\mathrm{Pt} / \mathrm{SiO}_{2}$ & 55 \\
\hline & & & 68 \\
\hline S5Pt-A & 300 & $\mathrm{Pt}_{0.95} \mathrm{Si}_{0.05} / \mathrm{Si}(100)$ & 130 \\
\hline S5Pt-B & 400 & $\mathrm{Pt}_{0.70} \mathrm{Si}_{0.30} / \mathrm{Si}(100)$ & 140 \\
\hline S5Pt-C & 500 & $\mathrm{Pt}_{0.60} \mathrm{Si}_{0.45} / \mathrm{Si}(100)$ & 80 \\
\hline & & & 80 \\
\hline S6Pt-A & 400 & $\mathrm{Pt} / \mathrm{MgO}(100)$ & 78 \\
\hline S6Pt-B & 500 & $\mathrm{Pt} / \mathrm{MgO}(100)$ & $\mathrm{Pt} / \mathrm{MgO}(100)$ \\
\hline S6Pt-C & 600 &
\end{tabular}


Difratogramas de XRD e curvas de histerese de filmes de FePt/Pt depositados sobre $\mathrm{SiO}_{2}$ (série 4) são apresentados na Figura 5.6. Em todos os casos pode-se verificar, através dos dados de XRD, que somente picos de difração FePt(111) e (222), além do pico $\operatorname{Pt}(111)$ do "buffer", são visualizados. $\mathrm{Em} \mathrm{T}_{\mathrm{S}}=300^{\circ} \mathrm{C}$, os valores em $2 \theta$ dos picos $\mathrm{FePt}(111)$ e (222) revelam a presença da fase estrutural FCC(111) no filme. As curvas de histerese desse
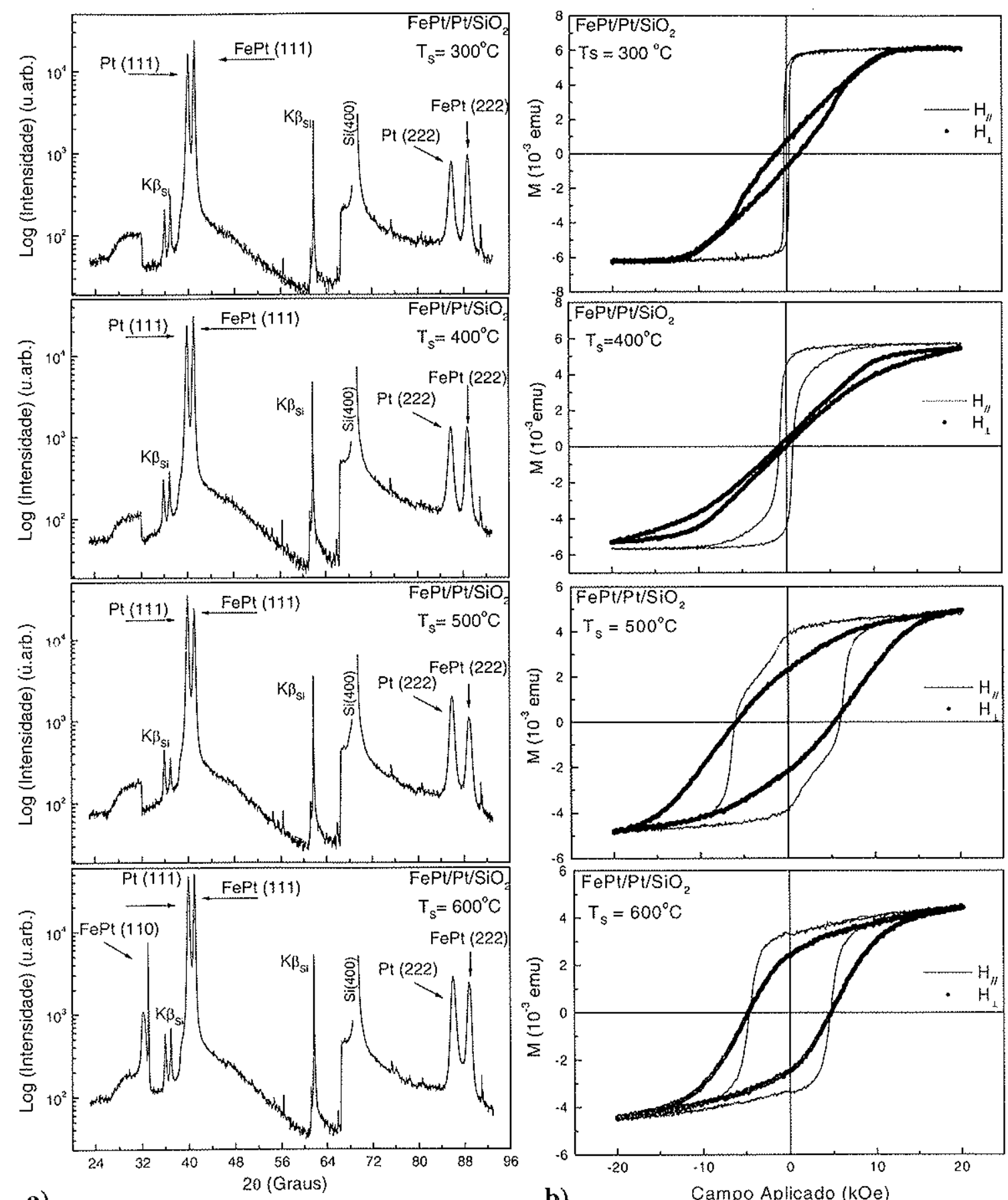

a)

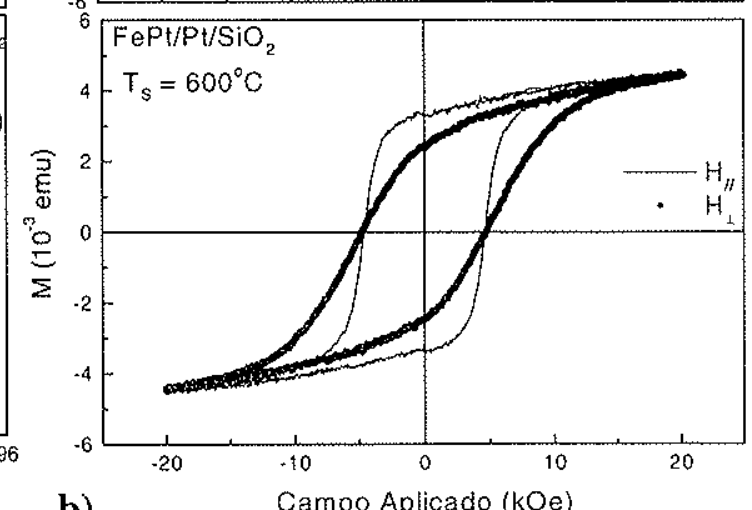

b)

Fig. 5.6 - (a) Difratogramas de XRD e (b) curvas de histerese de filmes de FePt/Pt depositados sobre substratos de $\mathrm{SiO}_{2}$. 
filme apresentam anisotropia magnética no plano e baixa coercividade, o que caracteriza a presença da fase $\mathrm{FCC}(111)$. Em $\mathrm{T}_{\mathrm{S}} \geq 400^{\circ} \mathrm{C}$, apenas pequenas mudanças nos valores de $2 \theta$ dos picos FePt(111) e (222) são observadas. A pequena diferença existente entre os valores de $2 \theta$ dos picos FePt(111) e (222) de uma estrutura FCC e FCT (ver apêndice I) impossibilita, em muitos casos, determinar com precisão qual é a estrutura cristalina presente no filme, utilizando somente dados de XRD. Com base no comportamento magnético pode-se verificar, através das curvas de histerese desses filmes (Fig. 5.6(b)), um crescimento da energia de anisotropia com o aumento da temperatura. Os valores de coercividade sofrem um aumento brusco (em ambas geometrias), conforme pode ser verificado pela Figura 5.7(c). Estes dados indicam a presença de uma mudança de fase estrutural no filme com o aumento de $\mathrm{T}_{S} . \mathrm{Em} \mathrm{T}_{\mathrm{S}}=500^{\circ} \mathrm{C}$, a forma da curva de histerese medida no plano do filme evidencia a presença de duas fases magnéticas no filme. Analisando os valores de área integrada dos picos de difração Pt(111) e FePt(111) (Fig. 5.7(a)), verificamos um crescimento monotônico para o pico $\mathrm{Pt}(111)$, diferentemente do pico $\mathrm{FePt}(111)$ que sofre uma redução em $\mathrm{T}_{S}=500^{\circ} \mathrm{C}$ seguido por um grande aumento em $600^{\circ} \mathrm{C}$, o que evidencia a presença de mudança de fase
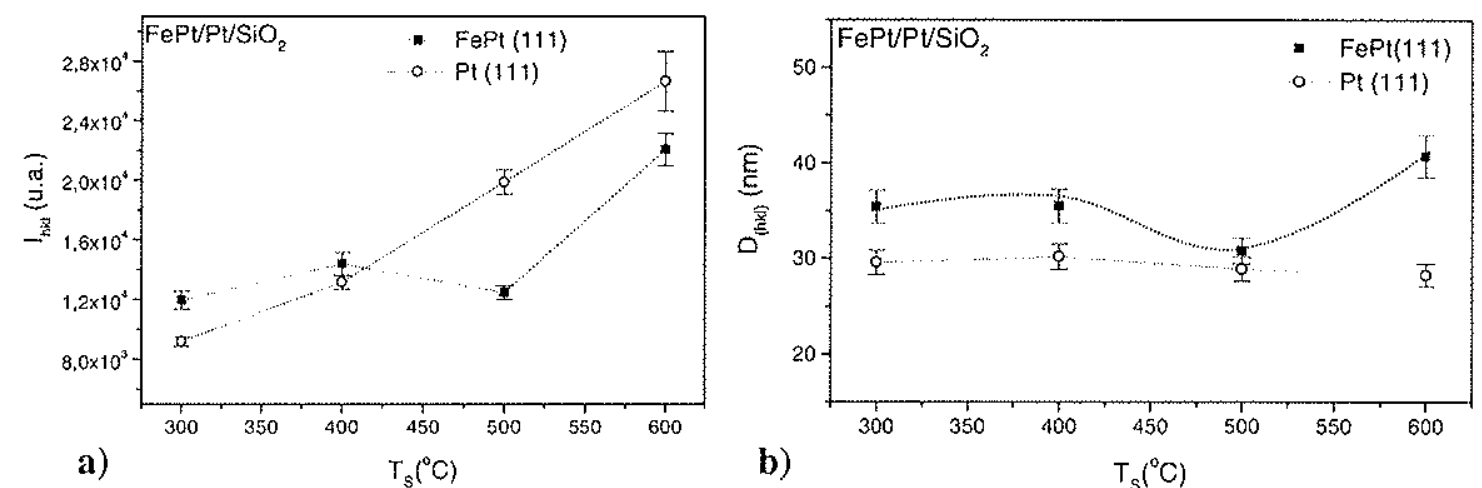

b)

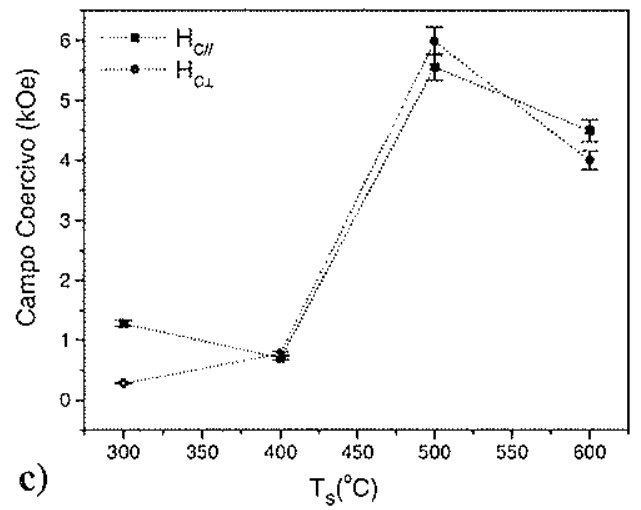

Fig. 5.7 - Gráficos com valores de (a) área integrada $\left(I_{h k l}\right)$, (b) tamanho médio do grão cristalino $\left(D_{h k l}\right), \quad$ e (c) campo coercivo $\left(\mathrm{H}_{\mathrm{C}}\right)$, em função da temperatura deo substrato $\left(\mathrm{T}_{S}\right)$, dos filmes de FePt/Pt depositados sobre substratos de $\mathrm{SiO}_{2}$. 
estrutural com o aumento de $\mathrm{T}_{S}$. Quanto aos valores de $D_{h k l}$ da camada FePt (Fig. 5.7(b)), verificamos um maior valor em $600^{\circ} \mathrm{C}$, indicando que o filme de FePt depositado em maior temperatura possui uma estrutura cristalina mais bem definida. Com base nos resultados obtidos, acreditamos que o surgimento de uma mudança de fase de FCC(111) para FCT(111) torna-se possível a partir $500^{\circ} \mathrm{C}$. $\mathrm{Em} 600^{\circ} \mathrm{C}$, a presença da fase $\mathrm{FCT}(111)$ é predominante. A presença de somente uma textura [111] na camada FePt é devido a influência do "buffer" de Pt. A camada de Pt depositada sobre $\mathrm{SiO}_{2}$, mesmo em altas temperaturas, desenvolve somente uma textura [111]. Na Figura 5.8 é apresentada uma superposição de difratogramas de XRD de amostras de $\mathrm{Pt} / \mathrm{SiO}_{2}$ da região que compreende o pico $\mathrm{Pt}(222)$. Um deslocamento do pico para maiores valores de $2 \theta$ e um crescimento da intensidade evidenciam a presença de melhor cristalinidade com o aumento de $\mathrm{T}_{\mathrm{S}}$.

Na Figura 5.9 são apresentados difratogramas de XRD e curvas de histerese de filmes de $\mathrm{FePt} / \mathrm{Pt}$ depositados sobre $\mathrm{Si}\left(100\right.$ ) (série 5). Para as amostras preparadas em $300^{\circ} \mathrm{C}$ e $400^{\circ} \mathrm{C}$ a presença de picos de difração $\operatorname{Pt}(111)$ (do "buffer") e FePt(111) evidenciam a presença de uma estrutura predominante FCC com textura [111] na camada FePt. Porém, com o aumento de $\mathrm{T}_{S}$ os picos $\mathrm{Pt}(111)$ e FePt(111) sofrem forte redução de intensidade e, em $500^{\circ} \mathrm{C}$, há o aparecimento de um pico de difração fortemente deslocado em relação ao pico $\operatorname{Pt}(111)$ e $\mathrm{FePt}(111)$, o qual é indexado como sendo pertencente a uma liga $\mathrm{Pt}_{2} \mathrm{Si}$. É provável que este

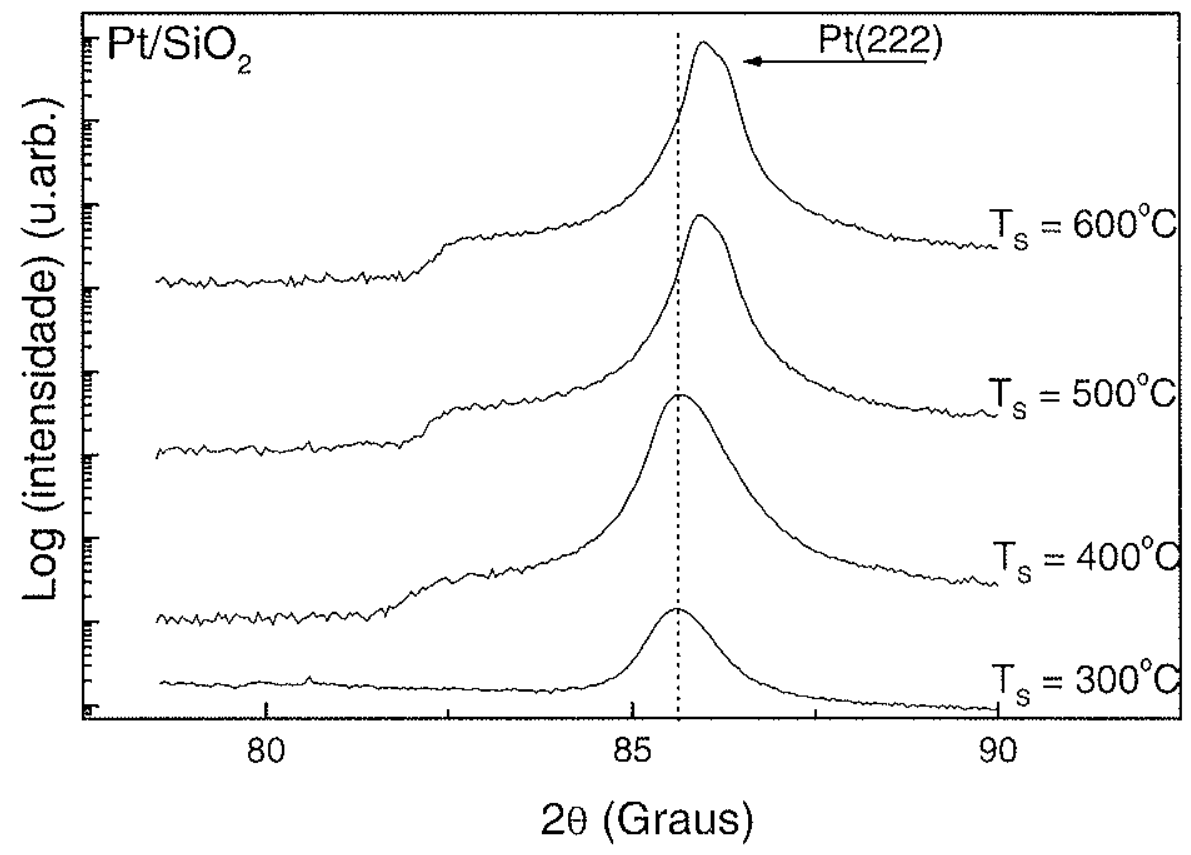

Fig. 5.8 - Superposição de difratogramas de XRD de filmes de Pt depositados sobre $\mathrm{SiO}_{2}$. 

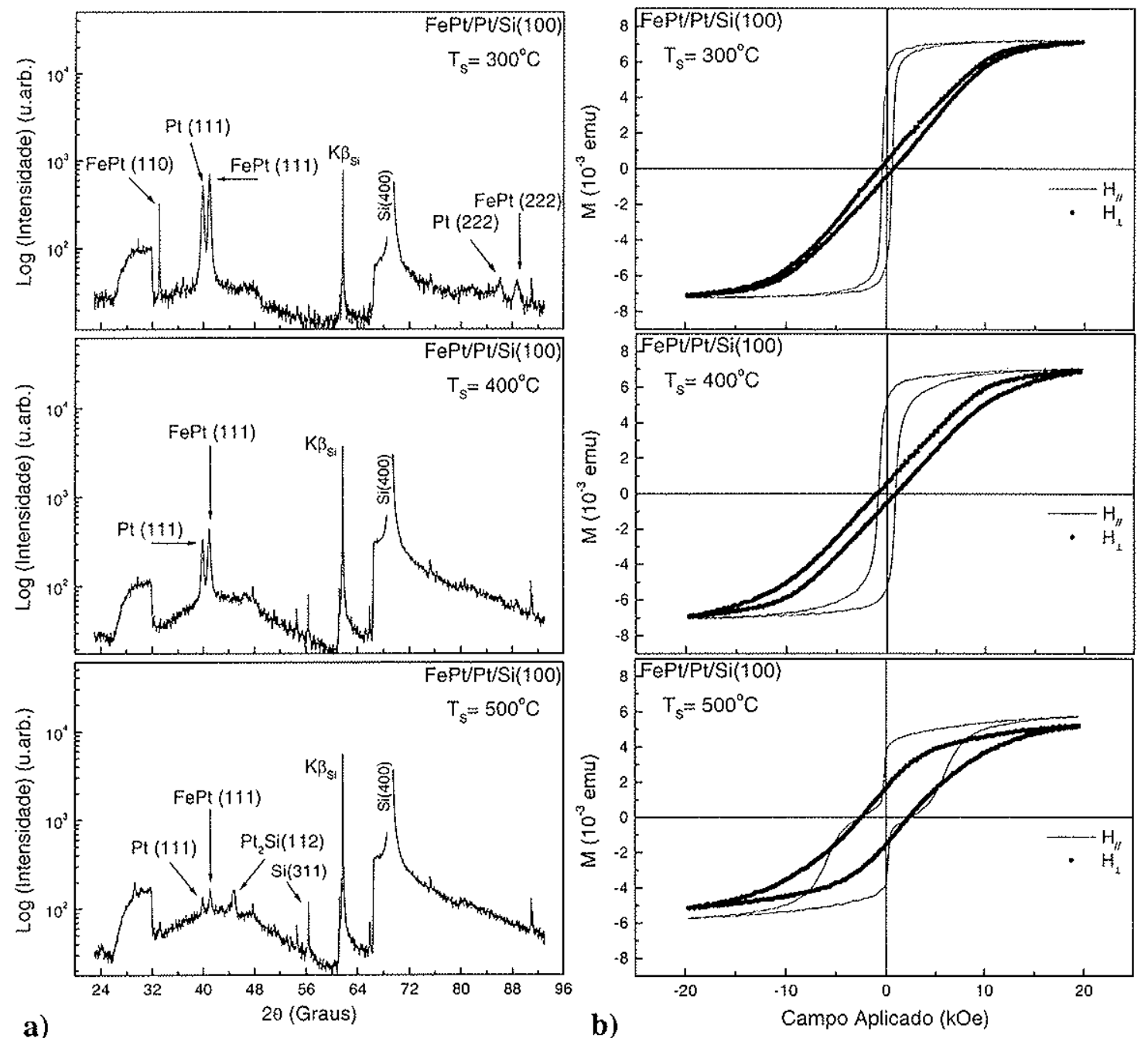

Fig. 5.9 - (a) Difratogramas de XRD e (b) curvas de histerese de filmes de FePt/Pt depositados sobre substratos de $\mathrm{Si}(100)$.

fenômeno seja devido a presença de uma forte interdifusão entre os átomos do "buffer" de Pt e do substrato de silício com o aumento de $\mathrm{T}_{\mathrm{S}}$, o que leva ao surgimento de uma nova fase estrutural que influência a estrutura do filme de FePt depositado por cima. Os Espectros de RBS dessas amostras (Fig. 5.10) reafirmam a presença de grande interdifusão entre os átomos da camada de $\mathrm{Pt}$ e do substrato de $\mathrm{Si}(100)$ com o aumento de $\mathrm{T}_{\mathrm{S}}$. As curvas de histerese dessas amostras apresentam anisotropia magnética no plano e um crescimento da coercividade, nas duas geometrias, de $\mathrm{T}_{\mathrm{S}}=300^{\circ} \mathrm{C}$ a $400^{\circ} \mathrm{C}$. O formato da curva medida em $\mathrm{T}_{\mathrm{S}}$ $=500^{\circ} \mathrm{C}$, na geometria no plano, revela a presença de uma transição de fase magnética na camada FePt, provavelmente devido aos efeitos de interdifusão atômica. Os difratogramas de XRD dos filmes de Pt depositados sobre $\mathrm{Si}(100)$ (Fig. 5.11) revelam a presença de uma 

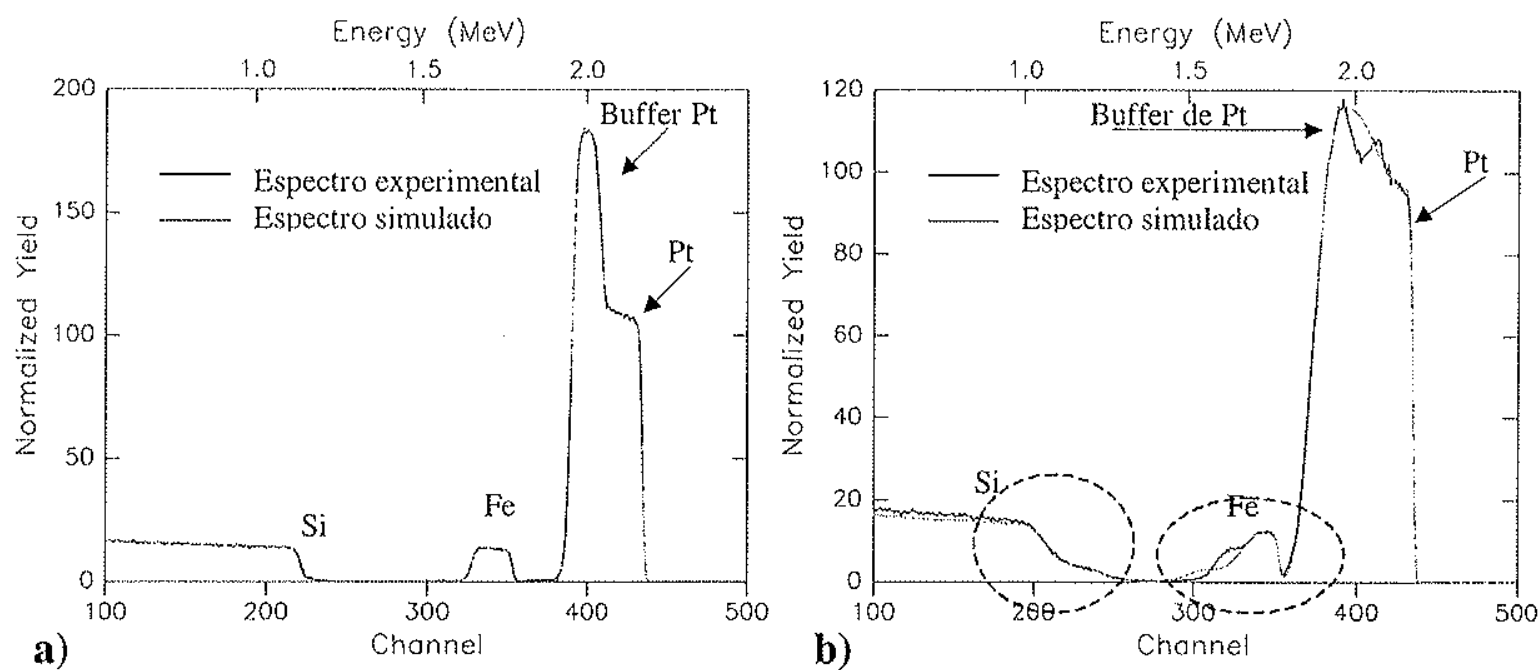

Fig. 5.10 - Espectros de RBS e respectiva simulação para filmes de FePt/Pt depositados sobre $\mathrm{Si}(100)$. (a) Amostra preparada em $\mathrm{T}_{S}=300^{\circ} \mathrm{C}$, onde se verifica baixíssimo efeito de interdifusão atômica. (b) Amostra preparada em $\mathrm{T}_{\mathrm{S}}=500^{\circ} \mathrm{C}$, onde se verifica grande efeito de interdifusão atômica (ver círculo pontilhado).

predominante fase estrutural Pt $\mathrm{FCC}(111)$ em $\mathrm{T}_{\mathrm{S}}=300^{\circ} \mathrm{C}$. Para maiores valores de $\mathrm{T}_{\mathrm{S}}$, os efeitos de interdifusão entre os átomos da Pt e o substrato são marcantes. Em $T_{S}=400^{\circ} \mathrm{C}$, o surgimento de um pico em $2 \theta \approx 44^{\circ}$ é indexado como sendo devido a uma liga $\mathrm{Pt}_{2} \mathrm{Si}$. Em $\mathrm{T}_{\mathrm{S}}$ $=500^{\circ} \mathrm{C}$, a ausência de picos de difração característicos da $\mathrm{Pt}$ revela que o filme não possui uma estrutura cristalina regular.

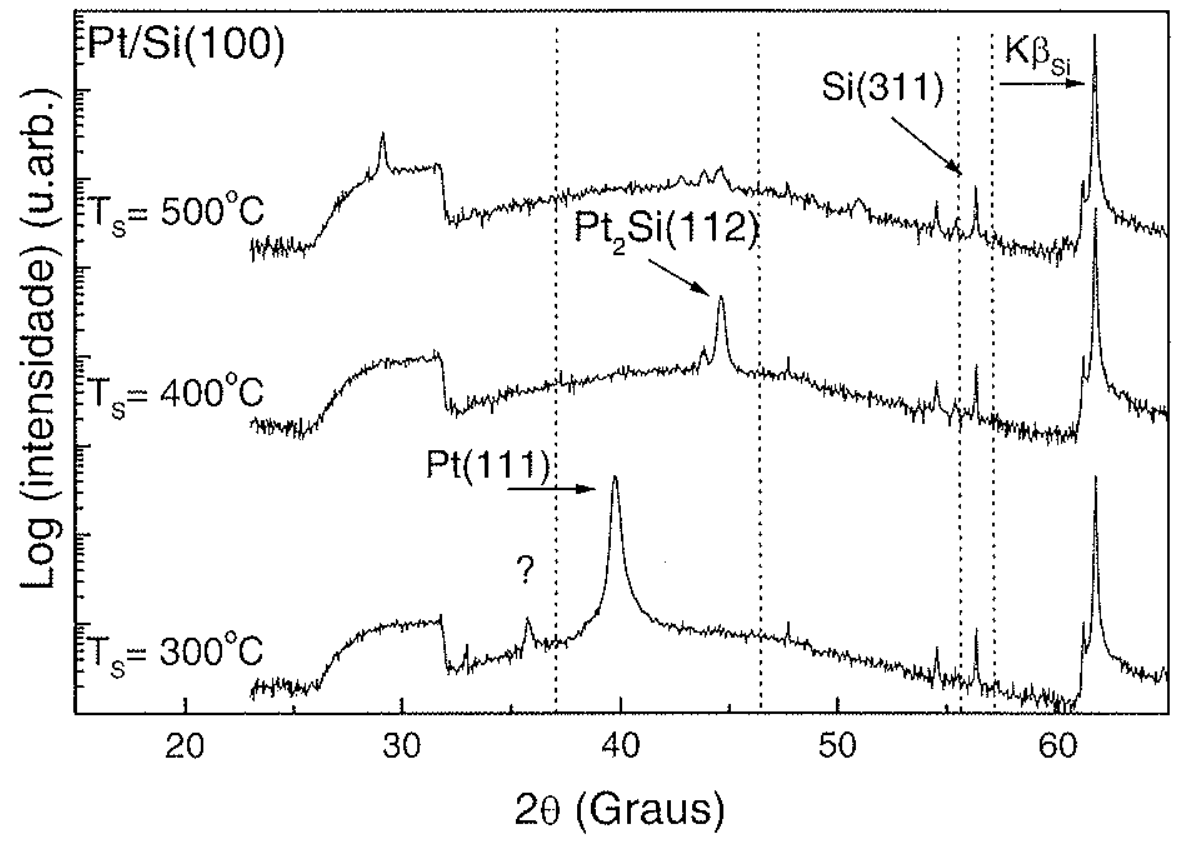

Fig. 5.11 - Superposição de difratogramas de XRD de filmes de Pt depositados sobre $\mathrm{Si}(100)$. 
Para os filmes de FePt/Pt depositados sobre $\mathrm{MgO}(100)$ (série 6), os resultados obtidos mostram a possibilidade de obtenção de uma fase estrutural FePt FCT(001) em moderados valores de $T_{\S}$. Na Figura 5.12 são apresentados difratogramas de XRD e curvas de histerese das amostras FePt/Pt/MgO(100). Pode-se verificar que em todos os casos existe a presença do pico de difração $\mathrm{Pt}(200)$ do "buffer" cuja intensidade é maior em $\mathrm{T}_{S}=400^{\circ} \mathrm{C}$. Em $\mathrm{T}_{\mathrm{S}}=300^{\circ} \mathrm{C}$, a presença de picos de difração FePt(111), (200) e (222) revelam a existência da estrutura FCC e uma mistura de texturas no filme. Nessa amostra, a presença de picos de difração $\mathrm{Pt}(111)$ e (200) indicam a existência de cristalitos do "buffer" com orientações cristalográficas diferentes que induzem, através de uma "epitaxia" granular, o crescimento de cristalitos da camada FePt também com orientações cristalográficas diferentes. Na amostra preparada em $400^{\circ} \mathrm{C}$ verificamos a presença dos picos de difração da super-rede $\mathrm{FePt}(001)$ e (003), característicos da estrutura ordenada $F C T$, além de um pico em $2 \theta=48,5^{\circ}$, o qual é indexado como sendo devido a presença de uma superposição de picos $\mathrm{FePt}(002)$, da estrutura FCT, e FePt(200), da estrutura FCC. As curvas de histerese desse filme mostram a presença de anisotropia magnética perpendicular, o que indica que a fase estrutural FCT(001) é predominante no filme. A coercividade medida na geometria perpendicular $\left(H_{C L}\right)$ possui um valor de $1,34 \mathrm{kOe}$. Na amostra preparada em $500^{\circ} \mathrm{C}$, um desdobramento dos picos $\mathrm{FePt}(002)$ (mais deslocado a direita) e (200) se torna possível. Nesse mesmo filme, também é verificado a presença dos picos de super-rede FePt(001) e (003). As curvas de histerese desse filme apresentam anisotropia magnética perpendicular e um valor de $H_{C \perp}$ de 1,25 kOe. Porém em $\mathrm{T}_{S}=600^{\circ} \mathrm{C}$ podemos ver que o pico $\mathrm{Pt}(200)$ do "buffer" sofre uma grande diminuição de intensidade e que também há a ausência de picos de difração característicos da camada FePt. Nessa amostra, efeitos de relaxação estrutural, produzidos pelo alto valor de $\mathrm{T}_{S}$, provocou uma redução do respectivo grau de cristalinidade. Os altos valores de coercividade obtidos para essa amostra $\left(\mathrm{H}_{\mathrm{C \perp}}=\mathrm{H}_{\mathrm{C} \downarrow} \approx 7 \mathrm{kOe}\right)$, são explicados como sendo devidos a presença de grande quantidade de defeitos estruturais. $O$ valor do parâmetro $S$ varia de 0,40 , em $\mathrm{T}_{\mathrm{S}}=$ $400^{\circ} \mathrm{C}$, para 0,65 , em $\mathrm{T}_{S}=500^{\circ} \mathrm{C}$, indicando maior grau de ordenamento químico na amostra depositada em maior valor de $T_{S}$. Esses resultados nos permitem afirmar que um crescimento "epitaxial" induzido da camada FePt sobre o "buffer" de Pt pré-depositado sobre o MgO possibilitou a obtenção da estrutura ordenada FCT, com uma textura [001], em uma temperatura $\left(\mathrm{T}_{\mathrm{S}}=400^{\circ} \mathrm{C}\right)$, abaixo da inicialmente obtida com as amostras de FePt $/ \mathrm{MgO}(100)\left(\mathrm{T}_{S}=600^{\circ} \mathrm{C}\right)$. Os melhores resultados obtidos com a utilização de um "bufer" de Pt pré-depositado sobre o $\mathrm{MgO}(100)$ podem ser compreendidos da seguinte maneira: a 


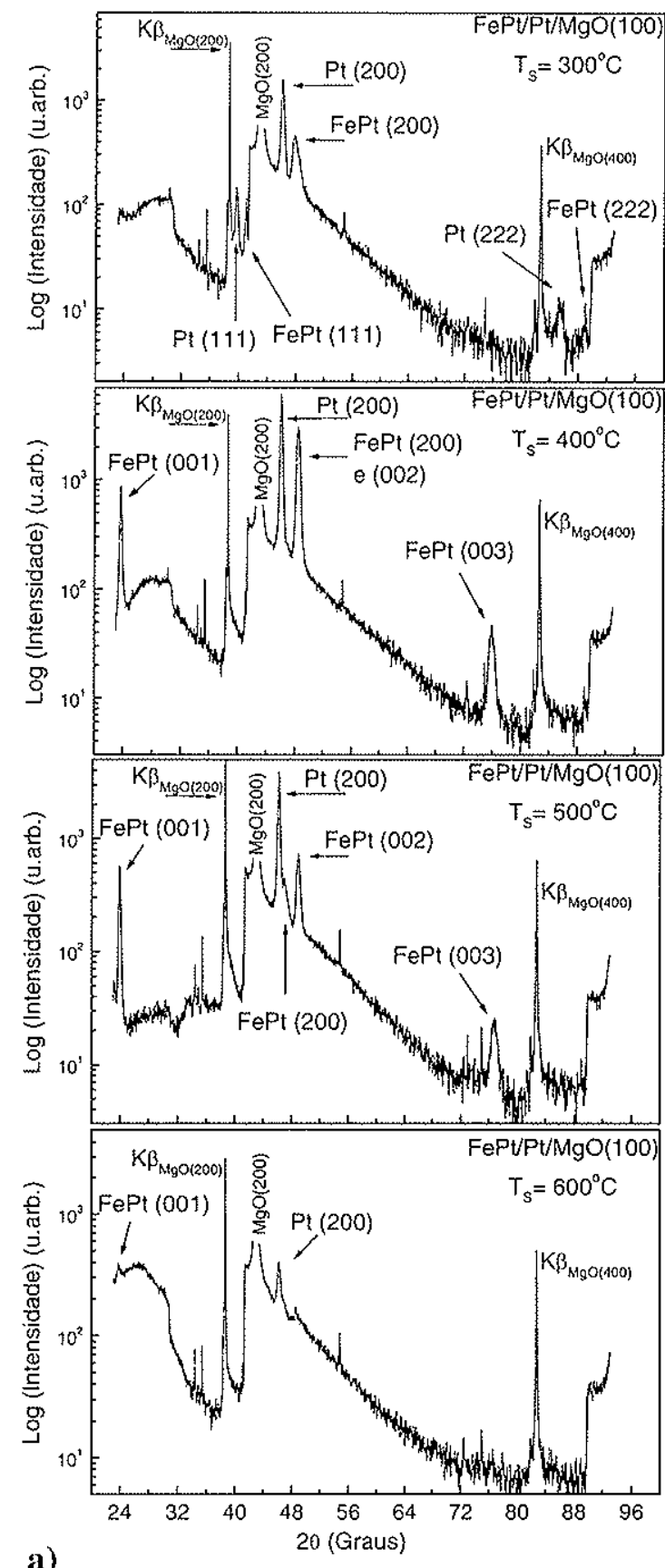

a)
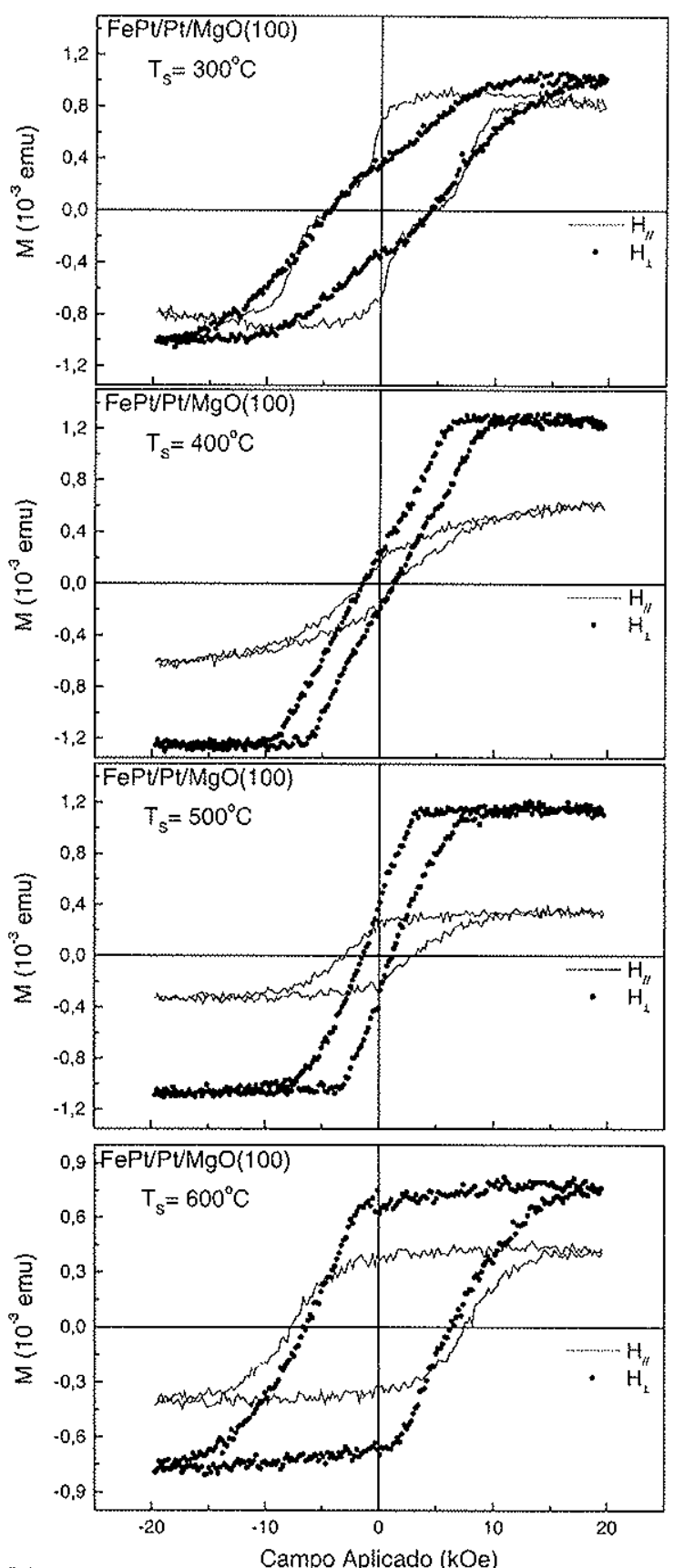

b)

Fig. 5.12 - (a) Difratogramas de XRD e (b) curvas de histerese de filmes de FePt/Pt depositados sobre substratos de $\mathrm{MgO}(100)$.

platina com uma estrutura FCC e textura predominante [100] é ideal para promover um crescimento "epitaxial" induzido de um filme de FePt com uma estrutura ordenada FCT e textura [001]. O substrato monocristalino de $\mathrm{MgO}(100)$ apresenta o tipo de estrutura desejada, porém, o seu parâmetro de rede é $\sim 9.4 \%$ maior que o parâmetro de rede da liga FePt cúbica, o que permite que os átomos da liga cresçam correlacionados com a estrutura do MgO somente com a preparação de amostras em altas temperaturas (devido a maior mobilidade atômica). Devido a maior compatibilidade estrutural, o $\mathrm{MgO}(100)$ tende a promover, com maior facilidade, o crescimento "epitaxial" de uma camada de Pt FCC com uma textura [100], pré- 
depositada sobre o mesmo, em moderados valores de $\mathrm{T}_{\mathrm{S}}$. A platina possui um parâmetro de rede (a) igual a $0.3923 \mathrm{~nm}$ (ver tabelas JCPDS - Anexo I), aproximadamente $2 \%$ maior que o respectivo valor do FePt cúbico. Portanto, as características adquiridas pelo "buffer" de Pt quando pré-depositado sobre $\mathrm{MgO}$ permitem então melhores condições para um crescimento "epitaxial" induzido de um filme de FePt com uma fase FCT(001). Na Figura 5.13 é apresentado uma superposição de difratogramas de raios-X de filmes de $\mathrm{Pt}$ sobre $\mathrm{MgO}(100)$. Verifica-se, para a amostra depositada em $\mathrm{T}_{\mathrm{S}}=400^{\circ} \mathrm{C}$, a existência somente do pico de difração $\mathrm{Pt}(200)$, evidenciando a presença de uma textura dominante [100]. Para as amostras depositadas em $\mathrm{T}_{\mathrm{S}}=500^{\circ} \mathrm{C}$ e $600^{\circ} \mathrm{C}$ verificamos a presença dos picos de difração Pt(200) (de maior intensidade) e da família de planos Pt(111) e Pt(222), o que revela a presença de uma mistura de texturas no filme, onde uma maior parcela de cristalitos estão orientados na direção [100] e uma menor parcela na direção [111]. Portanto, verificamos que a presença de uma estrutura FCC com somente uma textura [100] pôde ser obtida somente no filme crescido em $T_{S}=400^{\circ} \mathrm{C}$. Este resultado indica que a preparação de um filme de Pt sobre $\mathrm{MgO}(100)$ em altos valores de $\mathrm{T}_{S}$ tende a favorecer o desenvolvimento de uma textura [111] na mesma. Para ser utilizado como um "buffer" adequado para induzir um crescimento "epitaxial" de uma camada FePt com somente uma fase FCT(001), é necessário que a camada de $\mathrm{Pt}$ possua somente uma fase estrutural FCC(100).

Na literatura, diversos trabalhos demonstram a possibilidade de preparação de fulmes ordenados de FePt através da utilização de um "buffer" de Pt, pré-depositado sobre

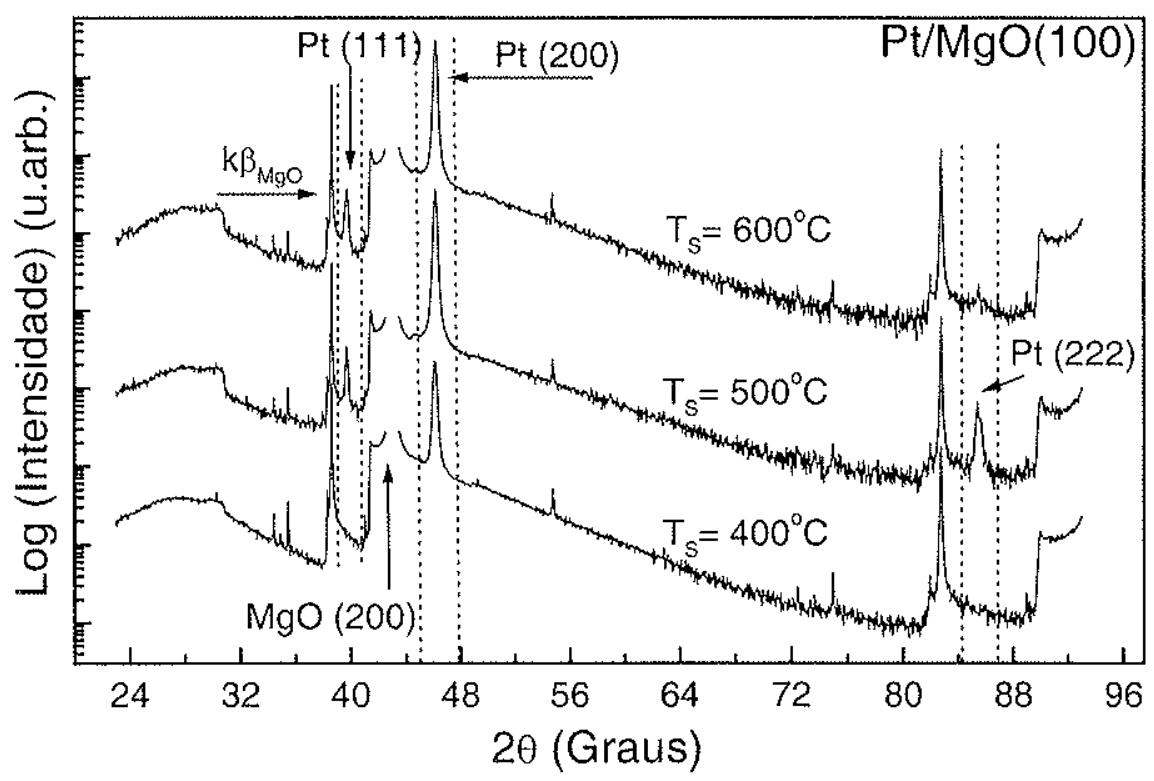

Fig. 5.13 - Superposição de difratogramas de XRD de filmes de $\mathrm{Pt}$ depositados sobre $\mathrm{MgO}(100)$. 
$\mathrm{MgO}(100)$. Thiele et al. [24] demonstraram a possibilidade de preparação de filmes ordenados de FePt com deposições sobre $\mathrm{Cr}(100) / \mathrm{Pt}(100) / \mathrm{MgO}(100)$, em $\mathrm{T}_{\mathrm{S}} \sim 550^{\circ} \mathrm{C}$. Em nosso trabalho não utilizamos a camada de Cr. Em outro trabalho, Kim et al. [28] conseguiram preparar filmes de FePt com a fase FCT(001), com deposições sobre um "buffer" de Pt de baixa espessura $(10 \mathrm{~nm}), \mathrm{em}_{\mathrm{S}} \geq 400^{\circ} \mathrm{C}$.

$\mathrm{Na}$ Tabela 5.5 são apresentadas propriedades como tipo de estrutura, textura principal e valores de campo coercivo medidos na geometria no plano $\left(H_{C / /}\right)$ e perpendicular ao plano $\left(H_{C l}\right)$, dos filmes de $\mathrm{FePt} / \mathrm{Pt}$ analisados.

Tabela 5.5 - Propriedades estruturais e magnéticas dos filmes de FePt/Pt depositados sobre substratos de $\mathrm{SiO}_{2}, \mathrm{Si}(100)$ e $\mathrm{MgO}(100)$

\begin{tabular}{|c|c|c|c|c|c|c|}
\hline Amostra & Composição & $\begin{array}{c}T_{S}\left({ }^{o} \mathrm{C}\right) \\
(\mathrm{Pt} / \mathrm{FePt})\end{array}$ & $\begin{array}{c}{ }^{\#} \text { Estrutura } \\
\text { predominante }\end{array}$ & $\begin{array}{c}\text { Textura } \\
\text { principal }\end{array}$ & $\begin{array}{c}H_{C / /} \\
(k O e)\end{array}$ & $\begin{array}{c}\boldsymbol{H}_{C . \ell} \\
(k \mathrm{Oe})\end{array}$ \\
\hline S4C-A & $\begin{array}{c}\mathrm{Fe}_{0.49} \mathrm{Pt}_{0.51} / \mathrm{Pt} \\
/ \mathrm{SiO}_{2}\end{array}$ & $300 / 300$ & FCC & [111] & 0,28 & 1,27 \\
\hline S4C-B & $\begin{array}{c}\mathrm{Fe}_{0.48} \mathrm{Pt}_{0.52} / \mathrm{Pt} \\
/ \mathrm{SiO}_{2}\end{array}$ & $400 / 400$ & FCC & [111] & 0,39 & 0,76 \\
\hline S4C-C & $\begin{array}{c}\mathrm{Fe}_{0.49} \mathrm{Pt}_{0.51} / \mathrm{Pt} \\
/ \mathrm{SiO}_{2}\end{array}$ & $500 / 500$ & $\mathrm{FCC} / \mathrm{FCT}$ & [111] & $5,98^{*}$ & $5,55^{*}$ \\
\hline S4C-D & $\begin{array}{c}\mathrm{Fe}_{0.49} \mathrm{Pt}_{0.51} / \mathrm{Pt} \\
/ \mathrm{SiO}_{2}\end{array}$ & $600 / 600$ & FCT & [111] & $4,00^{*}$ & $4,49^{*}$ \\
\hline S5C-A & $\begin{array}{c}\mathrm{Fe}_{0.51} \mathrm{Pt}_{0.49} \\
/ \mathrm{Pt}_{0.92} \mathrm{Si}_{0.08} / \mathrm{Si}(100\end{array}$ & $300 / 300$ & FCC & [111] & 0,53 & 0,68 \\
\hline S5C-B & $\begin{array}{c}\mathrm{Fe}_{0.51} \mathrm{Pt}_{0.49} \\
/ \mathrm{Pt}_{0.90} \mathrm{Si}_{0.10} / \mathrm{Si}(100\end{array}$ & $400 / 400$ & FCC & [111] & 0,88 & $0,98^{*}$ \\
\hline S5C-C & $\begin{array}{c}\mathrm{Fe}_{0.5 i} \mathrm{Pt}_{0.49} \\
/ \mathrm{Pt}_{0.55} \mathrm{Si}_{0.45} / \mathrm{Si}(100\end{array}$ & $500 / 500$ & indefinicia & indefinicia & $2,47^{*}$ & $2,36^{*}$ \\
\hline S6C-A & $\begin{array}{c}\mathrm{Fe}_{0.5 \mathrm{l}} \mathrm{Pt}_{0.49} / \mathrm{Pt} \\
/ \mathrm{MgO}(100)\end{array}$ & $300 / 300$ & FCC & $\begin{array}{c}{[111] \mathrm{e}} \\
{[100]}\end{array}$ & 4,33 & $4,35^{*}$ \\
\hline S6C-B & $\begin{array}{c}\mathrm{Fe}_{0.51} \mathrm{Pt}_{0.49} / \mathrm{Pt} \\
/ \mathrm{MgO}(100)\end{array}$ & $400 / 400$ & FCT & [001] & $1,33^{*}$ & 1,34 \\
\hline S6C-C & $\begin{array}{c}\mathrm{Fe}_{0.51} \mathrm{Pt}_{0.49} / \mathrm{Pt} / \\
\mathrm{MgO}(100)\end{array}$ & $500 / 500$ & FCT & {$[001]$} & $3,05^{*}$ & 1,25 \\
\hline S6C-D & $\begin{array}{c}\mathrm{Fe}_{0.51} \mathrm{Pt}_{0.49} / \mathrm{Pt} \\
/ \mathrm{MgO}(100)\end{array}$ & $600 / 600$ & Indefinida & indefinida & $7,64^{*}$ & $6,32 *$ \\
\hline
\end{tabular}

(\#) Camada FePt

(*) Valores obtidos em condições onde a magnetização não alcança a saturação com um campo magnético aplicado de $20 \mathrm{kOe}$.

Os resultados apresentados até o momento nos permite afirmar que:

a) Em filmes de FePt crescidos sobre substratos de $\mathrm{SiO}_{2}$ e $\mathrm{Si}(100)$ não é possível obter "epitaxia" conveniente para induzir um crescimento do filme com uma fase ordenada 
FCT(001), mesmo com um "buffer" de Pt e com deposições realizadas em altas temperaturas;

b) Para os filmes de FePt crescidos sobre substratos de $\mathrm{MgO}(100)$ obtivemos bons resultados de uma "epitaxia" conveniente para induzir um crescimento do filme com uma fase ordenada FCT(001). Nesses filmes, um alto grau de ordenamento químico e consequiente propriedades magnéticas (anisotropia magnética perpendicular e alta coercividade), foi conseguido com a amostra depositada à temperatura de $600^{\circ} \mathrm{C}$. Porém, com a utilização de um "buffer" de Pt, obteve-se melhores condições para induzir uma crescimento "epitaxial" do filme com uma fase FCT(001), com deposições realizadas em temperaturas menores.

\subsubsection{Filmes de FePt depositados sobre um "buffer" de Pt otimizado}

Devido aos bons resultados obtidos com a deposição de filmes de FePt sobre substratos de $\mathrm{MgO}(100)$, com um "buffer" de $\mathrm{Pt}$, resolvemos estudar a influência da espessura sobre as propriedades estruturais dessa camada, depositada sobre $\mathrm{MgO}(100)$. Com este estudo buscamos uma otimização do "buffer", cujos resultados foram utilizados na preparação de novas amostras.

Preparamos amostras de $\mathrm{Pt} / \mathrm{MgO}$ com espessuras de 2 a $52 \mathrm{~nm}$ em temperaturas do substrato de $200^{\circ} \mathrm{C}$ a $500^{\circ} \mathrm{C}$. As características das amostras produzidas são apresentadas nas Tabelas 5.6.

As análises estruturais através da técnica de XRD nos mostram que filmes de platina

Tabela 5.6 - Filmes de Platina (Pt) sobre substratos de $\mathrm{MgO}(100)$.

\begin{tabular}{cccc}
\hline Série & $T_{S}\left({ }^{\circ} \mathrm{C}\right)$ & Composicão & Espessura $(\mathbf{n m})$ \\
\hline S7Pt-A & 200 & $\mathrm{Pt} / \mathrm{MgO}(100)$ & 2,0 \\
\hline S7Pt -B & 300 & $\mathrm{Pt} / \mathrm{MgO}(100)$ & 2,0 \\
\hline S7Pt -C & 400 & $\mathrm{Pt} / \mathrm{MgO}(100)$ & 2,0 \\
\hline S7Pt -D & 500 & $\mathrm{Pt} / \mathrm{MgO}(100)$ & 2,0 \\
\hline & & & 19,5 \\
\hline S7Pt-E & 200 & $\mathrm{Pt} / \mathrm{MgO}(100)$ & 18,0 \\
\hline S7Pt -F & 300 & $\mathrm{Pt} / \mathrm{MgO}(100)$ & 25,0 \\
\hline S7Pt - G & 400 & $\mathrm{Pt} / \mathrm{MgO}(100)$ & 25,0 \\
\hline S7Pt -H & 500 & $\mathrm{Pt} / \mathrm{MgO}(100)$ & 51,0 \\
\hline & & & 51,0 \\
\hline S7Pt I & 200 & $\mathrm{Pt} / \mathrm{MgO}(100)$ & 51,5 \\
\hline S7Pt -J & 300 & $\mathrm{Pt} / \mathrm{MgO}(100)$ & 51,5 \\
\hline S7Pt -L & 400 & $\mathrm{Pt} / \mathrm{MgO}(100)$ & $\mathrm{Pt} / \mathrm{MgO}(100)$ \\
\hline S7Pt -M & 500 & &
\end{tabular}


depositados sobre subtratos de $\mathrm{MgO}(100)$ possuem uma estrutura cristalina tipo FCC com predominante textura [100]. Isto revela que o parâmetro de rede da platina possui grande facilidade de se combinar com o parâmetro de rede do $\mathrm{MgO}(100)$. Na Figura 5.14 e 5.15 são apresentados difratogramas de XRD das amostras estudadas. Juntamente a estes estudos, anexamos os resultados obtidos com os filmes de $\mathrm{Pt} / \mathrm{MgO}(100)$ (espessura 80nm - série 6) apresentados no item anterior. Os resultados de XRD mostram a presença de picos de difração Pt(200) de muito baixa intensidade para os filmes de Pt com espessuras de $2 \mathrm{~nm}$, mesmo quando depositados em maiores valores de $T_{S}$, revelando a presença de baixa cristalinidade nos filmes. Estes resultados indicam que nesta pequena espessura os átomos depositados no subtrato não formam um filme contínuo, mas pequenos aglomerados ou "ilhas" com pequena coalescência. Nos filmes de Pt com espessuras de $\sim 22 \mathrm{~nm}$ as medidas de XRD mostram que há um crescimento de intensidade dos picos de difração $\operatorname{Pt}(200)$ com o aumento de $\mathrm{T}_{S}$. Em $\mathrm{T}_{\mathrm{S}}=200^{\circ} \mathrm{C}$, um pico Pt(111), além do pico Pt(200), revela uma mistura de textura no filme, devido, provavelmente, ao baixo valor de $\mathrm{T}_{S}$. Para esta espessura acreditamos que, durante a deposição, os aglomerados de átomos formados crescem e coalescem, produzindo um filme com uma estrutura mais compacta. Os valores de $D_{h k l}$ variam de $11,8 \mathrm{~nm}$ em $\mathrm{T}_{\mathrm{S}}=200^{\circ} \mathrm{C}$ para $15,3 \mathrm{~nm}$ em $\mathrm{T}_{S}=500^{\circ} \mathrm{C}$, indicando uma melhor cristalinidade na amostra depositada no mais alto valor de $\mathrm{T}_{\mathrm{S}}$. Para os filmes de Pt com espessuras de $\sim 51 \mathrm{~nm}$, os resultados de XRD apresentam picos de difração $\operatorname{Pt}(200)$ de maior intensidade a partir de $\mathrm{T}_{\mathrm{S}}=200^{\circ} \mathrm{C}$, onde também há um aumento de intensidade com o crescimento de $T_{S}$. Porém, em $T_{S} \leq$ $300^{\circ} \mathrm{C}$, picos de difração $\mathrm{Pt}(111)$ também são visualizados, os quais decrescem de intensidade com o aumento de $T_{S}$. Os valores de tamanho médio do grão cristalino variam de $20,3 \mathrm{~nm}$ em $\mathrm{T}_{\mathrm{S}}=200^{\circ} \mathrm{C}$ para $27,4 \mathrm{~nm}$ em $\mathrm{T}_{S}=500^{\circ} \mathrm{C}$, evidenciando melhor cristalinidade com o aumento de $\mathrm{T}_{\mathrm{S}}$. Para a espessura de $\sim 51 \mathrm{~nm}$, acreditamos na existência de maior coalescência entre os aglomerados de átomos, possibilitando a formação de um bom filme contínuo. Conforme já descrito no item anterior, os resultados de XRD dos filmes de Pt com espessuras de $\sim 80$ nm revelam a presença de somente um pico de difração $\operatorname{Pt}(200)$, de alta intensidade, em $\mathrm{T}_{S}=400^{\circ} \mathrm{C}$. Para amostras preparadas em $\mathrm{T}_{S}>500^{\circ} \mathrm{C}$, verifica-se a presença de picos de difração $\mathrm{Pt}(200)$ (de maior intensidade) e Pt(111), o que indica a existência de uma mistura de texturas, com uma maior parcela de cristalitos orientados na direção [100] e uma menor parcela de cristalitos orientados na direção [111]. Isto mostra que para filmes de Pt espessos o aumento de $\mathrm{T}_{\mathrm{S}}$ favorece o desenvolvimento da textura [111]. Acreditamos que a textura [111] é induzida nas camadas mais externas do filme espesso, provavelmente devido a uma minimização da energia livre de superfície, que privilegia esta textura. 

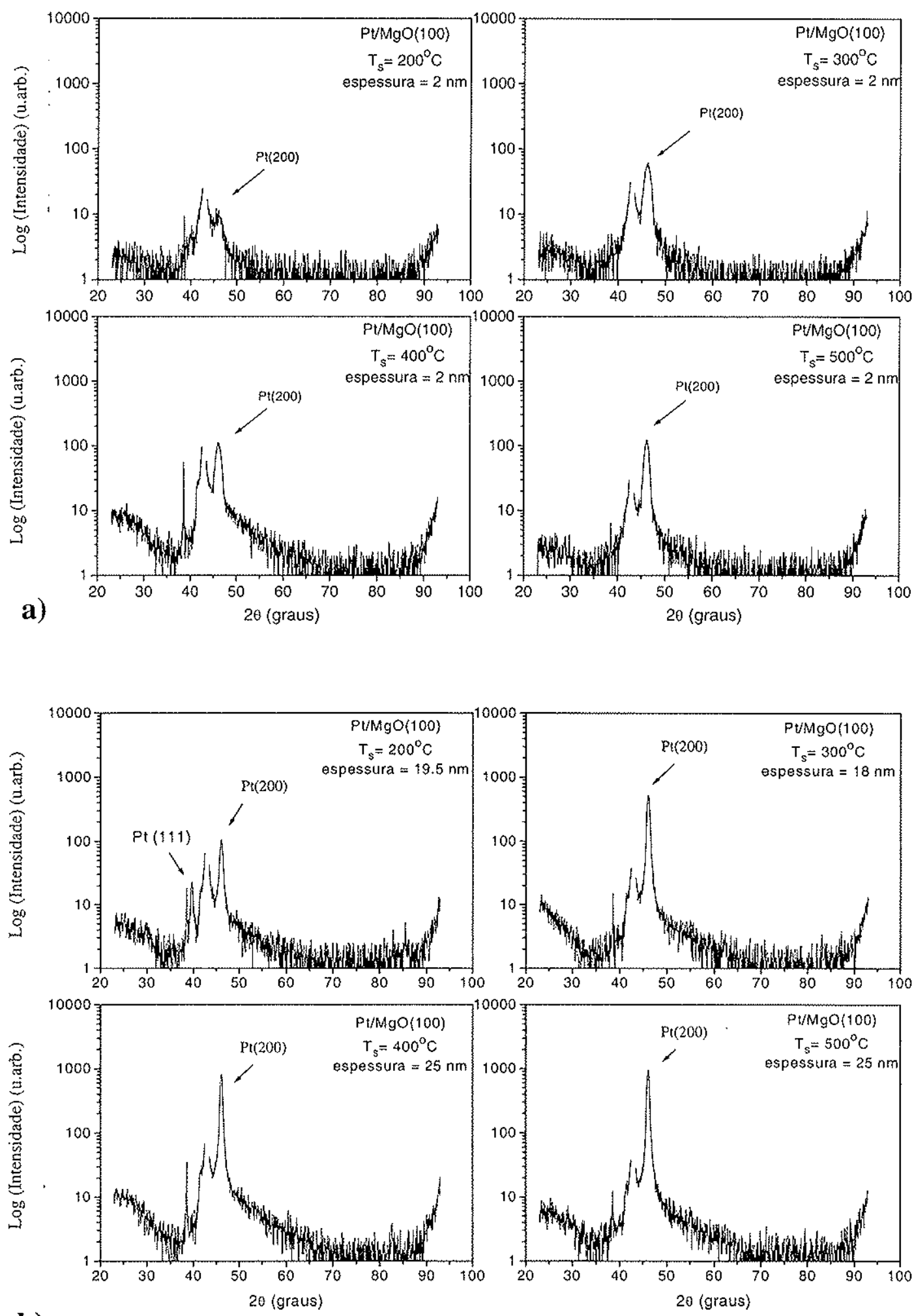

b)

Fig. 5.14 - Difratogramas de XRD de filmes de Pt depositados sobre substratos de $\mathrm{MgO}(100)$, em variados valores de $\mathrm{T}_{S}$, com espessuras de (a) $2 \mathrm{~nm}$ e (b) $\sim 22 \mathrm{~nm}$. 

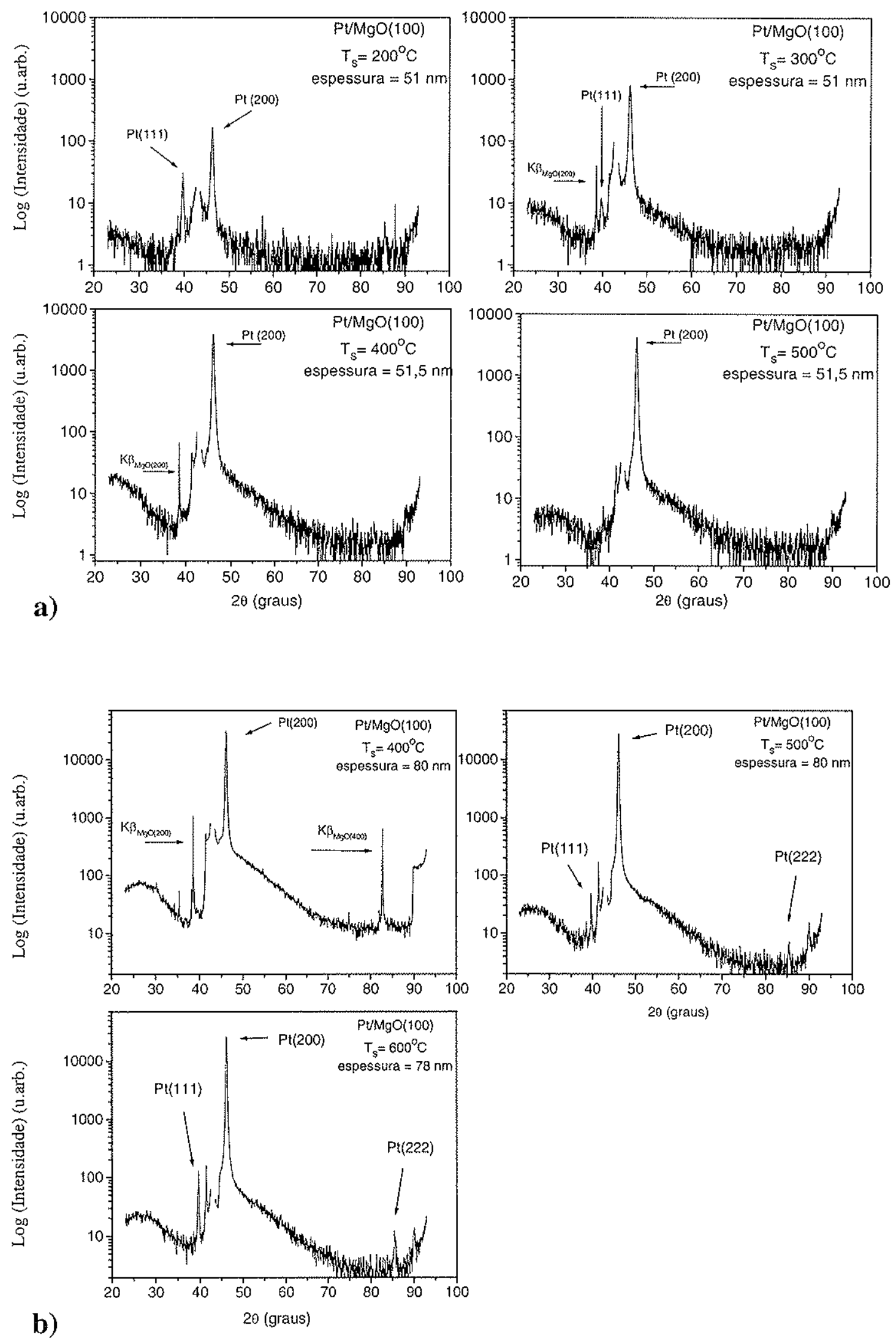

Fig. 5.15 - Difratogramas de XRD de filmes de Pt depositados sobre substratos de $\mathrm{MgO}(100)$, em variados valores de $\mathrm{T}_{S}$, com espessuras de (a) $\sim 51 \mathrm{~nm}$ e (b) $\sim 80 \mathrm{~nm}$. 
Através do estudo da dependência das propriedades estruturais de filmes de platina como uma função da espessura, crescidos sobre substratos $\mathrm{MgO}$ em diferentes $\mathrm{T}_{\mathrm{S}}$, encontramos que os melhores resultados em relação a uma definida estrutura cristalina (filme contínuo, alta cristalinidade e predominante textura [100]) foram obtidos para os filmes com espessuras de $\sim 51 \mathrm{~nm}$. Esses resultados foram utilizados na preparação de novas amostras de FePt/Pt/MgO, visando a obtenção de filmes de FePt com alto grau de ordenamento químico e em um menor valor de $\mathrm{T}_{\mathrm{S}}$.

Na preparação de novas amostras de $\mathrm{FePt} / \mathrm{Pt} / \mathrm{MgO}(100)$, utilizando o "buffer" de $\mathrm{Pt}$ otimizado, resolvemos utilizar espessuras menores para a camada FePt $(\sim 30 \mathrm{~nm})$, com o intuito de se verificar também a influência da espessura sobre as suas propriedades. Conforme já descrito no Capítulo 2, o alcance dos efeitos de um crescimento "epitaxial" induzido em um filme fino abrangem poucas camadas atômicas crescidas sobre a superfície de um monocristal. A medida em que a espessura aumenta, efeitos de relaxação estrutural no filme, provocados através da minimização da energia livre de superfície, são possíveis de ocorrerem.

É apresentado na Figura 5.16 um diagrama esquemático demonstrando como foram preparadas as amostras de FePt/Pt/MgO (série 7 - ver Tabela 5.2). Adotamos o procedimento de depositar, sobre as mesmas condições de preparação, o "buffer" em diferentes valores de $\mathrm{T}_{\mathrm{S}}$ seguido pela deposição da camada de FePt sobre um valor fixo de $\mathrm{T}_{\mathrm{S}}$. O porta substrato utilizado possibilita a deposição de um conjunto de três amostra a cada etapa de preparação (ver Capítulo 4). Na $1^{\mathrm{a}}$ e $2^{\mathrm{a}}$ etapas, iniciamos a deposição do "buffer" pela temperatura mais alta $\left(\mathrm{T}_{3}=500^{\circ} \mathrm{C}\right.$ ) (ver Fig. 5.16). Utilizamos este procedimento com a intuito de imnedir que a maioria dos "buffers" de Pt, pré-depositados, sofressem tratamento térmico. Pode-se ver que somente nos casos com um $\left({ }^{*}\right)$ o "buffer" sofreu tratamento térmico.

Na Figura 5.17 são apresentados difratogramas de XRD e curvas de histerese medidos para os filmes de FePt depositados em $\mathrm{T}_{S}=200^{\circ} \mathrm{C}$ sobre "buffers" de Pt previamente depositados sobre substratos de $\mathrm{MgO}$ em valores de $\mathrm{T}_{\mathrm{S}}$ de $200^{\circ} \mathrm{C}$ a $500^{\circ} \mathrm{C}$, conforme descrito no diagrama da Figura 5.16 ( $1^{\underline{a}}$ Etapa). Na amostra preparada em $\mathrm{T}_{\mathrm{S}}(\mathrm{Pt} / \mathrm{FePt})=200 / 200^{\circ} \mathrm{C}$, a presença de picos de difração Pt(200), Pt(111), FePt(111), FePt(200) e FePt(222), nos dados de XRD, revelam a existência de uma mistura de texturas tanto no "buffer" quanto na camada FePt. As texturas [111] e [100] da camada FePt são devido ao crescimento induzido provocado pelos cristalitos do "buffer" de Pt com texturas [111] e [100]. Para a amostra preparada em $\mathrm{T}_{\mathrm{S}}(\mathrm{Pt} / \mathrm{FePt})=300 / 200^{\circ} \mathrm{C}$, verifica-se a presença dos picos de difração $\mathrm{Pt}$ (111) (de intensidade induzida), Pt (200) e FePt(200). Para esta amostra, o maior valor de $\mathrm{T}_{S}$ para 


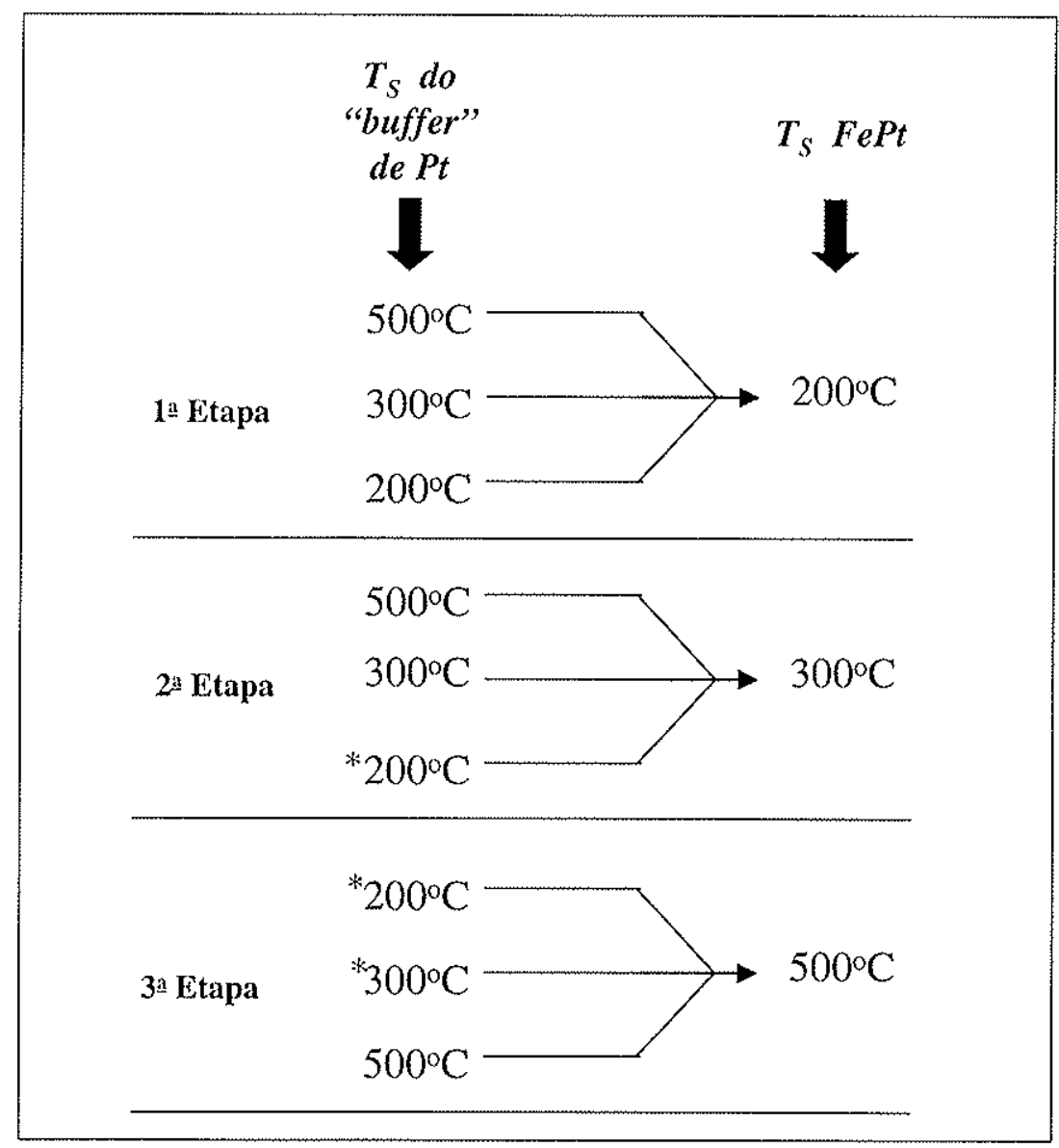

Fig. 5.16 - Diagrama esquemático com a sequência de deposição utilizada para a preparação de amostras de $\mathrm{FePt} / \mathrm{Pt} / \mathrm{MgO}$. Em cada etapa, primeiramente depositamos o "buffer" de Pt sobre o MgO nas temperaturas indicadas. Em seguida, depositamos, sobre os "buffers", a camada de FePt na respectiva temperatura indicada.

o "buffer" permitiu, para a sua estrutura, uma maior evoluçấo da textura $[100]$ em relação à [111]. Para a amostra preparada com $\mathrm{T}_{\mathrm{S}}(\mathrm{Pt} / \mathrm{FePt})=500 / 200^{\circ} \mathrm{C}$, verifica-se somente a presença dos picos de difração $\mathrm{Pt}(200)$ e FePt(200). Este resultado revela que a textura dominante do "buffer", resultado do alto valor de $T_{S}$ do mesmo, possibilitou a indução de uma única textura na camada FePt. As curvas de histerese das três amostras evidenciam a presença de anisotropia magnética no plano e pequenos valores de campo coercivo $\left(\mathrm{H}_{\mathrm{C} / /} \approx 0,33 \mathrm{kOe}\right)$. Os dados obtidos através da caracterização estrutural e magnética dessas amostras revelam a presença da estrutura cristalina FCC na camada FePt. Esses resultados mostram que não foi possível obter uma estrutura ordenada FCT para filmes de FePt depositados em $\mathrm{T}_{\mathrm{S}}=200^{\circ} \mathrm{C}$, mesmo quando crescidos sobre um "buffer" de Pt com uma dominante fase estrutural $\mathrm{FCC}(100)$.

Para os filmes de FePt depositados em $\mathrm{T}_{\mathrm{S}}=300^{\circ} \mathrm{C}$ sobre "buffers" de Pt prédepositados em diferentes valores de $\mathrm{T}_{\mathrm{S}}\left(2^{\mathrm{a}}\right.$ Etapa - Fig. 5.16), a obtenção da fase estrutural 

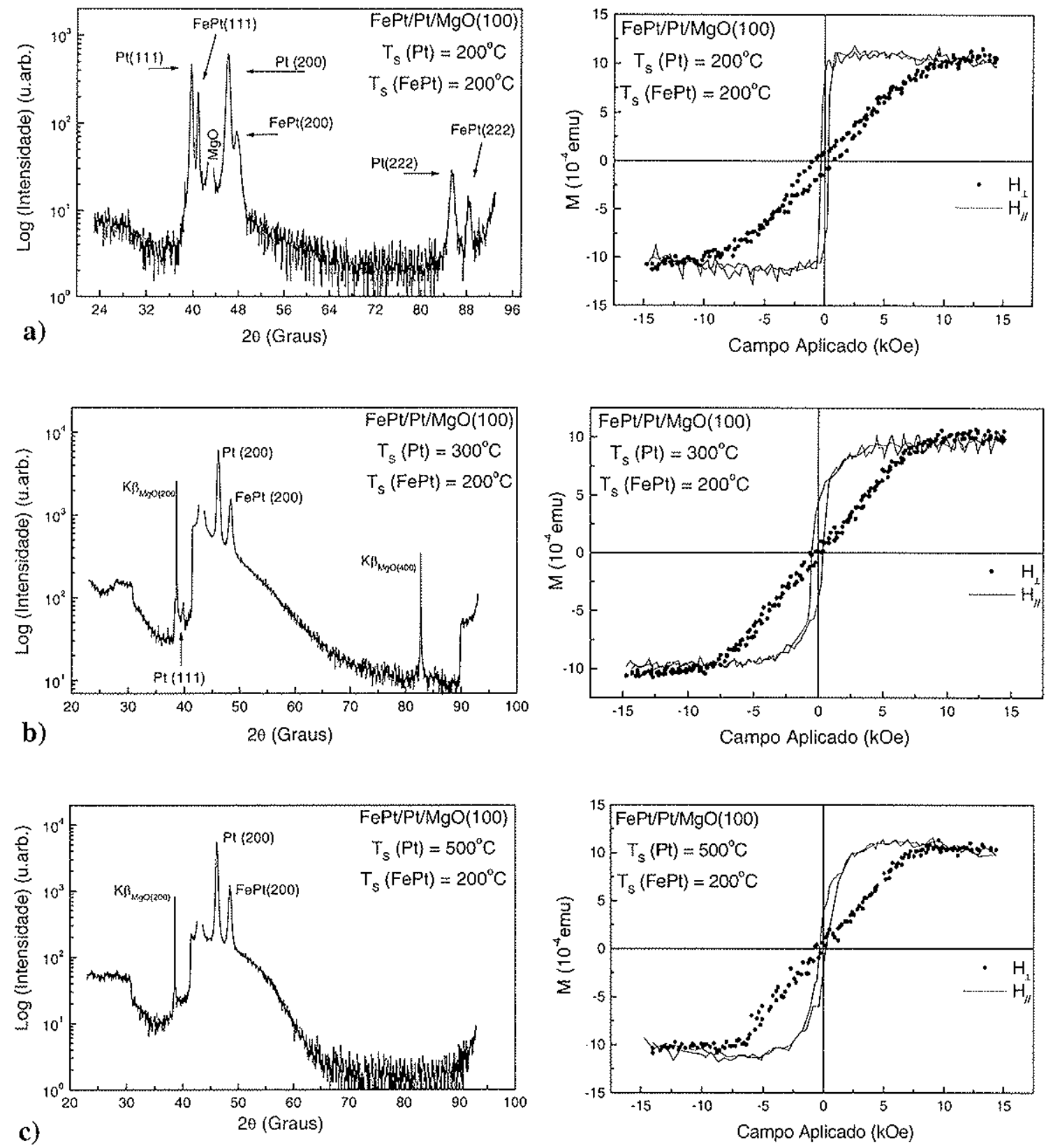

Fig. 5.17 - Difratogramas de XRD e curvas de histerese de filmes de FePt depositados em $\mathrm{T}_{\mathrm{S}}=200^{\circ} \mathrm{C}$ sobre um "buffer" de Pt pré-depositado sobre substratos de $\mathrm{MgO}(100) \mathrm{em}$ (a) $\mathrm{T}_{\mathrm{S}}=200^{\circ} \mathrm{C}$, (b) $\mathrm{T}_{\mathrm{S}}=300^{\circ} \mathrm{C}$ e (c) $\mathrm{T}_{\mathrm{S}}=500^{\circ} \mathrm{C}$.

FCT(001) tornou-se possível. Na Figura 5.18 são apresentados os difratogramas de XRD e curvas de histerese obtidos para essas amostras. Para a amostra preparada em $\mathrm{T}_{\mathrm{S}}(\mathrm{Pt} / \mathrm{FePt})=$ 200/300 ${ }^{\circ} \mathrm{C}$, verifica-se a presença de picos de difração $\operatorname{Pt}(111), \operatorname{Pt}(200), \operatorname{FePt}(111)$ e FePt(200). Para essa amostra, os valores de $2 \theta$ medidos para os picos FePt(111) e FePt(200), aproximadamente $40.9^{\circ}$ e $48.1^{\circ}$, respectivamente, revelam a presença de uma estrutura FCC com uma mistura de texturas [111] e [100], na camada FePt. Para essa amostra, o "buffer" 

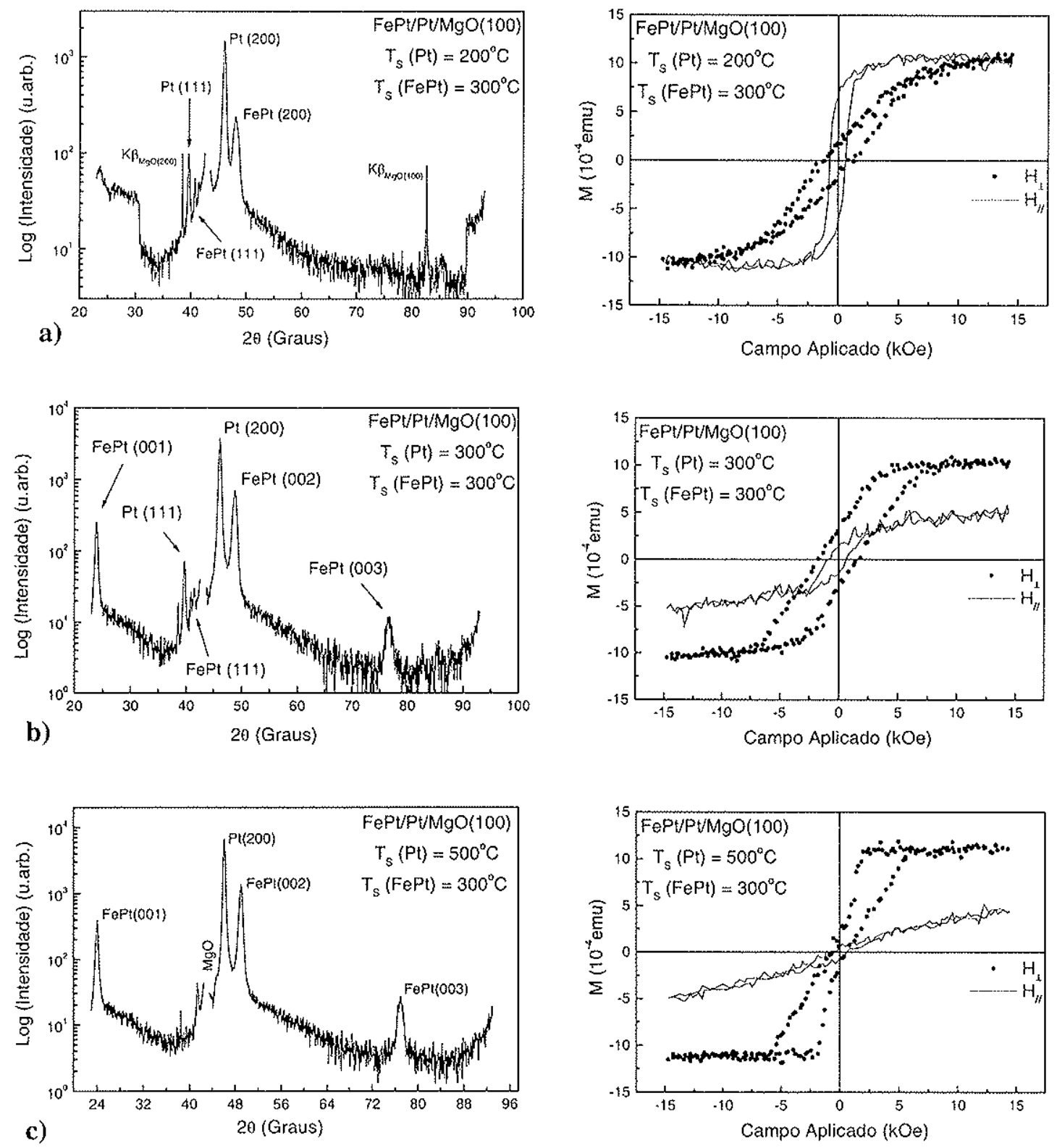

Fig. 5.18 - Difratogramas de XRD e curvas de histerese de filmes de FePt depositados em $\mathrm{T}_{\mathrm{S}}=300^{\circ} \mathrm{C}$ sobre um "buffer" de Pt pré-depositado sobre substratos de $\mathrm{MgO}(100)$ em (a) $\mathrm{T}_{\mathrm{S}}=200^{\circ} \mathrm{C}$, (b) $\mathrm{T}_{\mathrm{S}}=300^{\circ} \mathrm{C}$ e (c) $\mathrm{T}_{\mathrm{S}}=500^{\circ} \mathrm{C}$.

$\left(\mathrm{T}_{\mathrm{S}}=200^{\circ} \mathrm{C}\right)$ sofreu um tratamento térmico durante a deposição da camada FePt $\left(\mathrm{T}_{\mathrm{S}}=300^{\circ} \mathrm{C}\right)$, o que possibilitou uma melhor evolução da textura [100] em relação à sua textura [111]. As curvas de histerese mostram anisotropia planar, devido a estrutura FCC, e um valor de coercividade no plano $\left(\mathrm{H}_{\mathrm{C} / /}\right)$ de 0,60 kOe. Para a amostra preparada em $\mathrm{T}_{\mathrm{S}}(\mathrm{Pt} / \mathrm{FePt})=$ $300 / 300^{\circ} \mathrm{C}$, os dados de XRD mostram a presença de picos de difração Pt(111) (baixa intensidade) e Pt(200) do "buffer" e dos picos de difração de super-rede FePt(001) e FePt(003), característicos da fase FCT(001), além dos picos FePt(002) e (111). O valor de $2 \theta$ medido para o pico FePt(111) é de aproximadamente $40,9^{\circ}$, indexado como sendo de uma 
estrutura cristalina FCC. Este resultado indica que a camada FePt possui uma mistura de fases $\mathrm{FCT}(001)$ e $\mathrm{FCC}(111)$. A baixa intensidade do pico de difração FePt(111) revela que a maioria dos cristalitos da camada de FePt possuem a fase FCT(001). Analisando as curvas de histerese desta amostra, verificamos a presença de anisotropia magnética perpendicular, devido à predominância da fase $\mathrm{FCT}(001)$. $\mathrm{Na}$ última amostra desta etapa, preparada em $\mathrm{T}_{\mathrm{S}}(\mathrm{Pt} / \mathrm{FePt})=500 / 300^{\circ} \mathrm{C}$, os dados de XRD mostram a presença somente do pico de difração $\mathrm{Pt}(200)$ do "buffer" e dos picos de difração de super-rede FePt(001) e FePt(003), além do pico fundamental FePt(002), para a camada FePt. Este resultado indica que a camada FePt possui uma fase estrutural predominante $\mathrm{FCT}(001)$, devido ao crescimento induzido provocado pela definida estrutura cristalina do "buffer" de Pt (com somente uma textura [100]) e ao valor de $\mathrm{T}_{S}=300^{\circ} \mathrm{C}$ da camada FePt. As curvas de histerese dessa amostra evidenciam a presença de uma anisotropia magnética perpendicular, devido a fase FePt FCT(001). Os resultados de caracterização estrutural e magnética obtidos para as três amostras mostradas anteriormente, mostram que é possível obter uma fase FCT(001) em filmes de FePt crescidos em $\mathrm{T}_{\mathrm{S}}=300^{\circ} \mathrm{C}$ sobre um "buffer" de Pt com uma forte textura [100].

Para as amostras preparadas de acordo com a última etapa descrita no diagrama da Figura 5.16, apresentamos, na Figura 5.19, os respectivos difratogramas de XRD e curvas de histerese. Para essas amostras, a camada FePt foi depositada em $\mathrm{T}_{\mathrm{S}}=500^{\circ} \mathrm{C}$. Na Figura 5.19(a), onde a amostra foi preparada em $\mathrm{T}_{\mathrm{S}}(\mathrm{Pt} / \mathrm{FePt})=200 / 500^{\circ} \mathrm{C}$, os dados de XRD mostram somente a presença de um pico de difração de baixa intensidade Pt(111) do "buffer". Nenhum pico de difração da liga FePt é verificado. Para essa amostr" : "buffer" $\left(\mathrm{T}_{\mathrm{S}}=200^{\circ} \mathrm{C}\right)$ sofreu um forte tratamento térmico durante a deposição da camada $\mathrm{FePt}\left(\mathrm{T}_{S}=500^{\circ} \mathrm{C}\right)$. O espectro de RBS dessa amostra (Fig.5.20(b)) mostra a presença de um forte efeito de interdifusão atômica entre os átomos da camada FePt e do "buffer". Portanto, acreditamos que o alto valor de $\mathrm{T}_{\mathrm{S}}$ da camada $\mathrm{FePt}$, seguido pelo tratamento térmico no "buffer", possibilitou a geração de uma forte interdifusão atômica entre os átomos das duas camadas, formando uma estrutura cristalina pouco definida para essa amostra. Consequentemente, as medidas magnéticas dessa amostra não mostram curvas de histerese de formato típico. Para as amostras com os "buffers" pré-depositados em $\mathrm{T}_{\mathrm{S}}=300^{\circ} \mathrm{C}$ e $\mathrm{T}_{\mathrm{S}}=500^{\circ} \mathrm{C}$, os dados de XRD mostram a presença dos picos de difração Pt(200) do "buffer", e dos picos de difração FePt(001), (002) e (003) da camada FePt. Para essas duas amostras, os resultados obtidos mostram a presença predominante da fase estrutural $\mathrm{FCT}(001)$ na camada FePt, devido ao alto valor de $\mathrm{T}_{\mathrm{S}}$ no qual esta camada foi depositada e também ao crescimento induzido provocado pelo "buffer" de Pt FCC(100). As curvas de histerese das duas amostras 

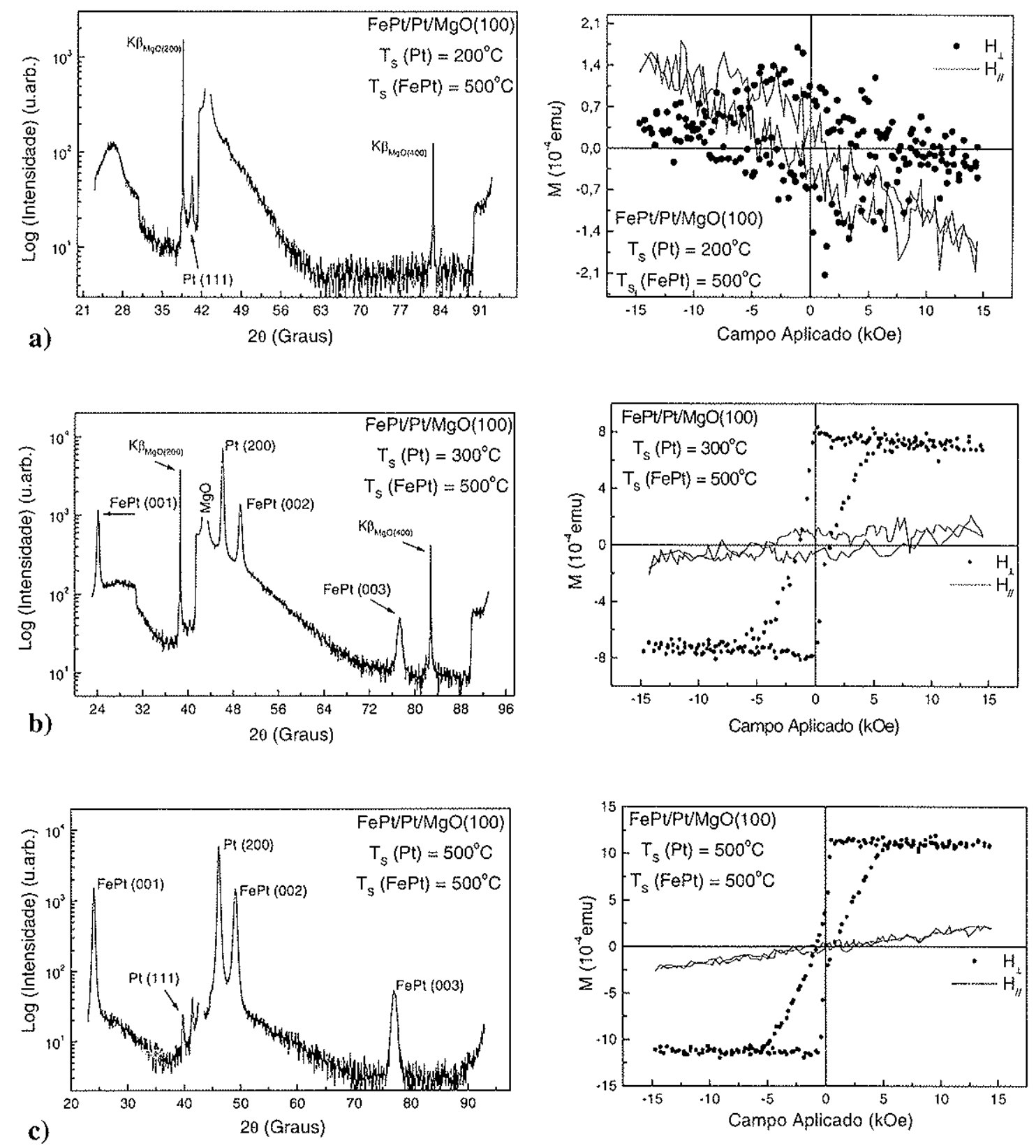

Fig. 5.19 - Difratogramas de XRD e curvas de histerese de filmes de FePt depositados em $\mathrm{T}_{\mathrm{S}}=500^{\circ} \mathrm{C}$ sobre um "buffer" de $\mathrm{Pt}$ pré-depositado sobre substratos de $\mathrm{MgO}(100)$ em (a) $\mathrm{T}_{S}=200^{\circ} \mathrm{C}$, (b) $\mathrm{T}_{S}=300^{\circ} \mathrm{C}$ e (c) $\mathrm{T}_{S}=500^{\circ} \mathrm{C}$.

apresentam anisotropia magnética perpendicular, devido a fase FCT(001). Esses resultados evidenciam a possibilidade de obtenção de filmes de FePt FCT(001), com alto grau de ordenamento químico, crescidos sobre "bufer" de Pt FCC(100) a partir de uma condição de preparação com valores de $\mathrm{T}_{\mathrm{S}}(\mathrm{Pt} \backslash \mathrm{FePt})=300 \backslash 500^{\circ} \mathrm{C}$.

Valores de tamanho médio do grão cristalino $\left(D_{h k l}\right)$, parâmetro de ordenamento químico de longo alcance de $(S)$ e de campo coercivo perpendicular $\left(H_{C \perp}\right)$, para os filmes de FePt preparados e que apresentam a fase FCT(001), são apresentados na Tabela 5.7. É 

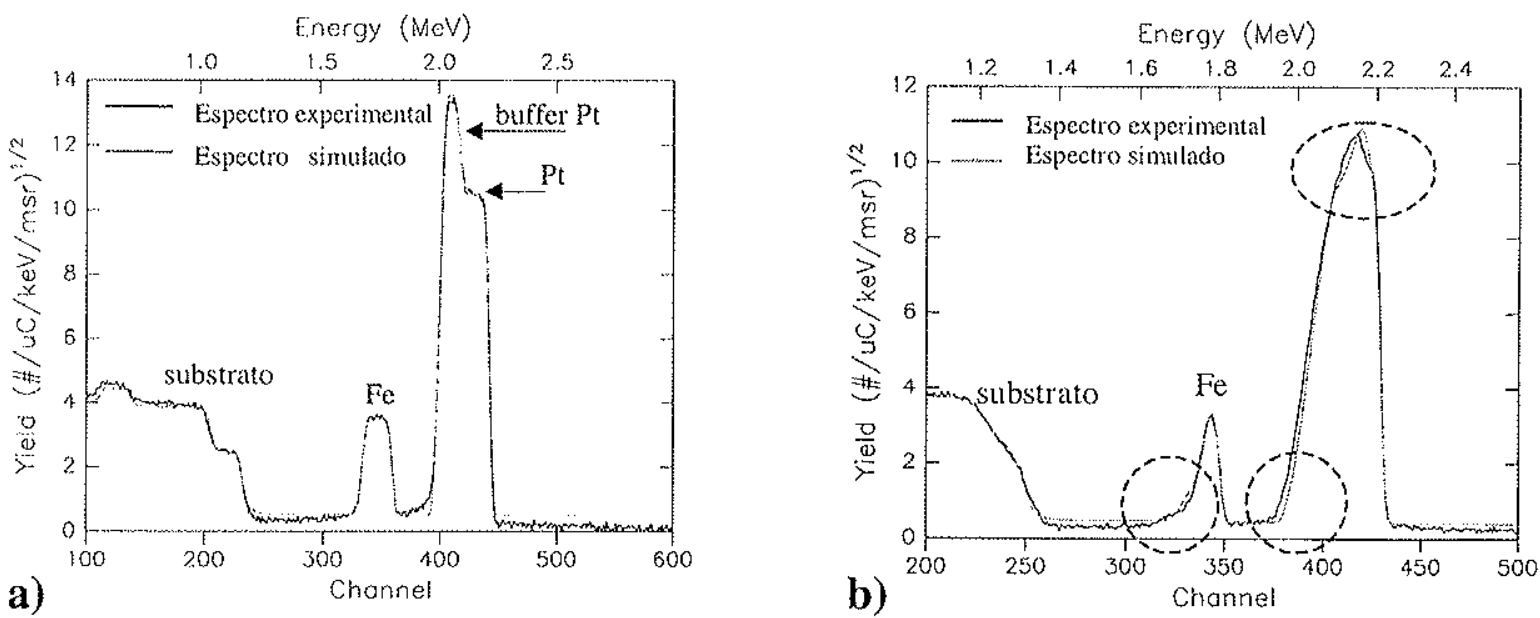

Fig. 5.20 - Espectros de RBS e respectiva simulações para filmes de FePt/Pt. (a) Amostra com pequeno efeito de interdifusão atômica entre camada FePt e o "buffer" de Pt. (b) Amostra preparada em $\mathrm{T}_{\mathrm{S}}(\mathrm{Pt} \backslash \mathrm{FePt})=200 \backslash 500^{\circ} \mathrm{C}$ com grande efeito de interdifusão atômica entre as camadas (ver círculo pontilhado).

possível verificar que os filmes de FePt depositados em maiores valores de $\mathrm{T}_{\mathrm{S}}$ apresentam maior grau de ordenamento químico, sendo este parâmetro maior para a amostra S3C-D. Isto confirma que a alta temperatura do substrato favorece a evolução de um melhor ordenamento químico, numa escala de longo alcance, em filmes de FePt. Pode-se também verificar que os filmes de FePt mais espessos apresentam os maiores valores de $D_{h k l}$. Para estes casos, o valor de $D_{h k l}$ cresce com o aumento de $\mathrm{T}_{\mathrm{S}}$ da camada FePt. A mesma característica é observada para os filmes de FePt menos espessos. Para os filmes de FePt menos espessos e que possuem maiores valores de $S$, também é observado que os valores de $D_{h k l}$ são muito próximos. Quanto aos valores de campo coercivo meciidos na geometria perpendicular ao plano do filme $\left(H_{C . L}\right)$ (condição de saturação da magnetização), é possível verificar valores de

Tabela 5.7 - Valores de tamanho médio do grão cristalino $\left(D_{h k l}\right)$, parâmetro de de ordenamento químico de longo alcance de $(S)$ e campo coercivo perpendicular $\left(H_{C \perp}\right)$, para os filmes de $\mathrm{FePt}$ que apresentam a fase $\mathrm{FCT}(001)$.

\begin{tabular}{|c|c|c|c|c|c|c|}
\hline Amostra & Composição & $\begin{array}{c}T_{S}\left(^{\circ} \mathrm{C}\right) \\
(\text { Pt/FePt })\end{array}$ & $\begin{array}{c}\text { Espessura } \\
(\text { nm }) \\
(\text { FePt/Pt })\end{array}$ & $\begin{array}{c}D_{001} \\
(\text { nm })\end{array}$ & $S$ & $\begin{array}{c}H_{C \perp} \\
(\text { kOe })\end{array}$ \\
\hline S3C-D & $\mathrm{Fe}_{0.52} \mathrm{Pt}_{0.48}$ & $-/ 600$ & $115 /-$ & 51,8 & 0,89 & 1,00 \\
\hline S6C-B & $\mathrm{Fe}_{0.51} \mathrm{Pt}_{0.49} / \mathrm{Pt}$ & $400 / 400$ & $105.1 / 76$ & 29,1 & 0,40 & 1,34 \\
\hline S6C-C & $\mathrm{Fe}_{0.51} \mathrm{Pt}_{0.49} / \mathrm{Pt}$ & $500 / 500$ & $103.5 / 70$ & 34,6 & 0,65 & 1,25 \\
\hline S7C-E & $\mathrm{Fe}_{0.46} \mathrm{Pt}_{0.49} \mathrm{R}_{0.06} / \mathrm{Pt}$ & $300 / 300$ & $34 / 50$ & 19,38 & 0,45 & 1,70 \\
\hline S7C-H & $\mathrm{Fe}_{0.47} \mathrm{Pt}_{0.47} \mathrm{R}_{0.06} / \mathrm{Pt}$ & $300 / 500$ & $32 / 50$ & 25,6 & 0,78 & 1,20 \\
\hline S7C-D & $\mathrm{Fe}_{0.48} \mathrm{Pt}_{0.47} \mathrm{R}_{0.05} / \mathrm{Pt}$ & $500 / 300$ & $34 / 50$ & 20,0 & 0,46 & 0,80 \\
\hline S7C-I & $\mathrm{Fe}_{0.47} \mathrm{Pt}_{0.47} \mathrm{R}_{0.06} / \mathrm{Pt}$ & $500 / 500$ & $32 / 50$ & 25,7 & 0,80 & 0,75 \\
\hline
\end{tabular}

*Filmes crescidos sobre substratos de $\mathrm{MgO}(100)$.

$\mathrm{R}=$ Contaminantes 

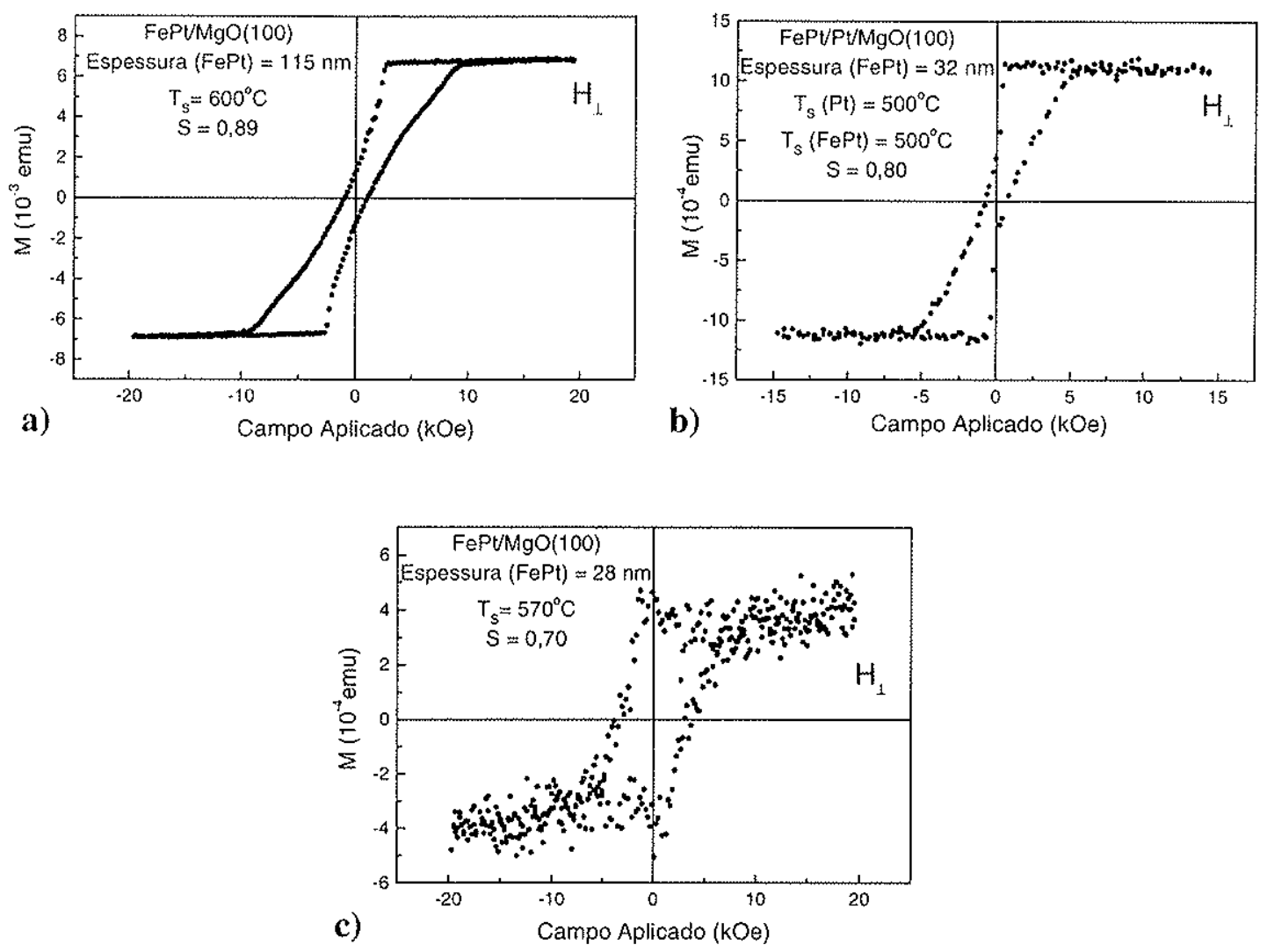

Fig. 5.21 - Curvas de histerese (medidas na geometria perpendicular ao plano do filme) de amostras que possuem uma fase estrutural predominate FePt FCT(001) (alto grau de ordenamento químico) e cujas as camadas FePt possuem espessuras diferentes.

$\sim 1$ kOe para os filmes de FePt com os maiores valores de $S$ (maior grau de ordenamento químico). Para a amostra S7C-E, verifica-se maior valor de campo coercivo $\left(\mathrm{H}_{\mathrm{C} \perp .} \sim 1.7 \mathrm{kOe}\right)$, o qual pode ser devido a mistura de texturas na camada FePt.

Comparando as curvas de histerese das amostras S3C-D e S7C-I (Fig. 5.21), medidas na geometria perpendicular ao plano do filme, cujas camadas FePt são de espessuras diferentes e que apresentaram os maiores valores de $S$, podemos verificar um aumento da remanência a medida que a espessura diminui. A diminuição da remanência é interpretado como sendo devido a efeitos de relaxação estrutural da camada FePt com o aumento da espessura, os quais influenciam as propriedades magnéticas do material. Os efeitos de um crescimento "epitaxial" induzido diminuem com o aumento da espessura. Portanto, com o aumento da espessura e a redução dos efeitos de um crescimento induzido, a estrutura resultante tende a ser gerada pela minimização da energia livre de superfície. Para a camada FePt, a minimização da energia livre de superfície gera a textura [111], pois o plano (111) é o plano de maior empacotamento atômico. Na Figura 5.21(c) é mostrada uma curva de histerese perpendicular de uma amostra teste de FePt/MgO, com uma fase FePt FCT(001) $(S=0,70)$, 
depositada por codeposição, cuja camada de FePt possui uma espessura menor que as das amostras anteriores. A baixa resolução da curva de histerese dessa amostra, e também das outras curvas obtidas para as amostras menos espessas, se deve ao limite de sensibilidade do VSM utilizado $\left(\sim 10^{-5} \mathrm{emu}\right)$. Pode-se verificar que, com uma espessura ainda menor, a forma da curva se torna mais quadrada e com maior remanência quando comparada com as curvas das outras amostras (Fig. 5.21(a) e (b)), comprovando que os efeitos da espessura da camada FePt são também determinantes para a formação da estrutura.

\subsection{Filmes Preparados pelo Método de Deposição Alternada de Monocamadas (DAM)}

Conforme já citado, uma estrutura cristalina quimicamente ordenada FCT (tipo $\mathrm{L}_{0}$ ) pode ser descrita como uma sequência de planos alternados formados, cada um, pelos diferentes átomos constituintes da liga (ver Fig. 2.3 - Capítulo 2). Esta importante característica é que nos levou a acreditar na possibilidade de preparar filmes finos de ligas FePt, com alto grau de ordenamento químico, simplesmente depositando, alternadamente, uma monocamada de cada elemento constituinte da liga. Filmes de ligas binárias (FePt, FePd, $\mathrm{FeAu}$, etc..) com uma estrutura tipo $\mathrm{L} 1_{0}$ têm sido usualmente preparadas, por DAM, com a utilização de sistemas que permitem condições de deposição quase perfeitas (MBE, etc) $[31,53,54]$. Nesses sistemas, os átomos formadores do filme depositam ^e sobre o substrato com menor energia cinética, permitindo uma melhor acomodação dos mesmos. Todo o processo de deposição ocorre em ambiente de UHV, o que reduz o grau de contaminação. Em um estudo desenvolvido por Shima et al. [31] é demonstrado a possibilidade de preparação de filmes de FePt com a fase $\mathrm{FCT}(001)$, em $\mathrm{T}_{\mathrm{S}} \leq 230^{\circ} \mathrm{C}$. Entretanto, sistemas que operam em UHV não são comumente utilizados no ambiente industrial, devido ao elevado custo de operação. Na industria, o sistema de "sputtering" é considerado o mais adequado para preparação de filmes. Porém, no sistema de "sputtering", existe uma grande dificuldade de se obter um elevado controle das condições de deposição. Da literatura, um trabalho de autoria de Shima et al. [55] demonstra a possibilidade de preparação, por "sputtering", de filmes de FePt com a fase $\mathrm{FCT}(001)$ e um valor de $\mathrm{S}=0.60$, em $\mathrm{T}_{\mathrm{S}} \approx 300^{\circ} \mathrm{C}$. Porém, os procedimentos experimentais utilizados não são descritos claramente. Em nosso trabalho, fizemos diversos estudos até chegar a uma condição mais favorável possível que permitisse a preparação de filmes ordenados de FePt através do método de DAM, utilizando um sistema de "sputtering". 
Quanto ao aparato experimental, algumas modificações foram necessárias, com o intuito de se obter um maior controle dos parâmetros de deposição. Os detalhes foram descritos no Capítulo 3. Com o objetivo de alcançar uma melhor acomodação atômica sobre a superfície do substrato, através da redução do fluxo de átomos "sputterados", utilizamos reduzidos valores de potência de "sputtering". Realizamos também, um estudo preliminar sobre a influência do valor da pressão de deposição nas propriedades estruturais dos filmes de FePt. Depositamos monocamadas Fe/Pt sobre um "buffer" de Pt $(\sim 60 \mathrm{~nm})$, pré-depositado sobre substrato $\mathrm{MgO}(100)$. Utilizamos pressões de deposição de 2, 5 e $10 \mathrm{~m}$ Torr para as monocamadas Fe/Pt. Para o "buffer", mantivemos a pressão de deposição em 5 mTorr. Nessas primeiras amostras, o "buffer" e as monocamadas Fe/Pt foram depositadas sobre o mesmo valor de $\mathrm{T}_{\mathrm{S}}\left(400^{\circ} \mathrm{C}\right)$. Cada monocamada de Fe ou Pt foi depositada em uma sequiência de 90 repetições. A composição foi examinada ex-situ por RBS, que revelou a existência de filmes com concentrações atômicas próximas a 50\% e espessuras de $\sim 38 \mathrm{~nm}$. Por simplicidade, substituiremos o termo "monocamadas de Fe/Pt" por somente "camada FePt" durante a descrição das amostras preparadas pelo método de DAM

$\mathrm{Na}$ Figura 5.22 são apresentados em conjunto os espectros de RBS (com as respectivas simulações) e difratogramas $\mathrm{XRD}$ das amostras FePt/Pt/MgO(100). Analisando os espectros de RBS é possível verificar, para a amostra com a camada FePt preparada em 2 mTorr, a existência de grande interdifusão atômica entre os átomos da camada magnética e do "buffer" (ver linha pontilhada - Fig. 5.22)(a)). Nos dados de XRD de todas as amostras, a presença de picos de difração FePt(001), (002) e (003), caracterizam a presença da fase estrutural FCT(001) na camada FePt. Na amostra com a camada FePt depositada em 5 mTorr, picos mais estreitos e de maior intensidade são claramente observados. De outro modo, para a amostra com a camada FePt depositada em 10 mTorr, verifica-se um decréscimo na intensidade dos picos e um alargamento do pico FePt(002). É de conhecimento geral que, em menores pressões de deposição, existe um maior livre caminho médio para os átomos que migram na direção do substrato [13]. Isto faz com que estes átomos sejam depositados sobre o substrato com alta energia cinética, prejudicando a cristalinidade do filme. Por outro lado, em maiores pressões de deposição, o livre caminho médio dos átomos diminui, devido a um maior número colisões, permitindo que átomos com menor energia sejam depositados sobre o substrato. Porém, nessas condições existe a possibilidade de se obter um maior número de contaminantes na amostra, o que também prejudica a cristalinidade do filme. Portanto, esse estudo preliminar nos mostra que a melhor condição encontrada para a preparação de filmes de FePt com boa cristalinidade, foi com uma pressão de deposição de 5 mTorr. Portanto, nas 

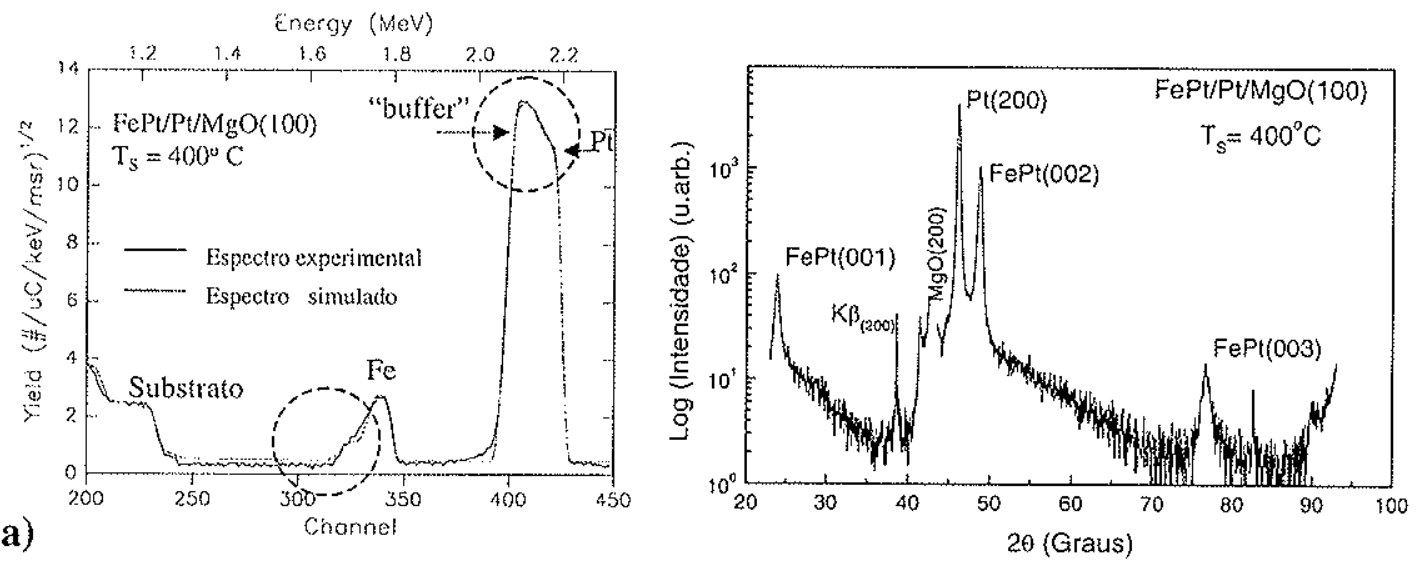

a)
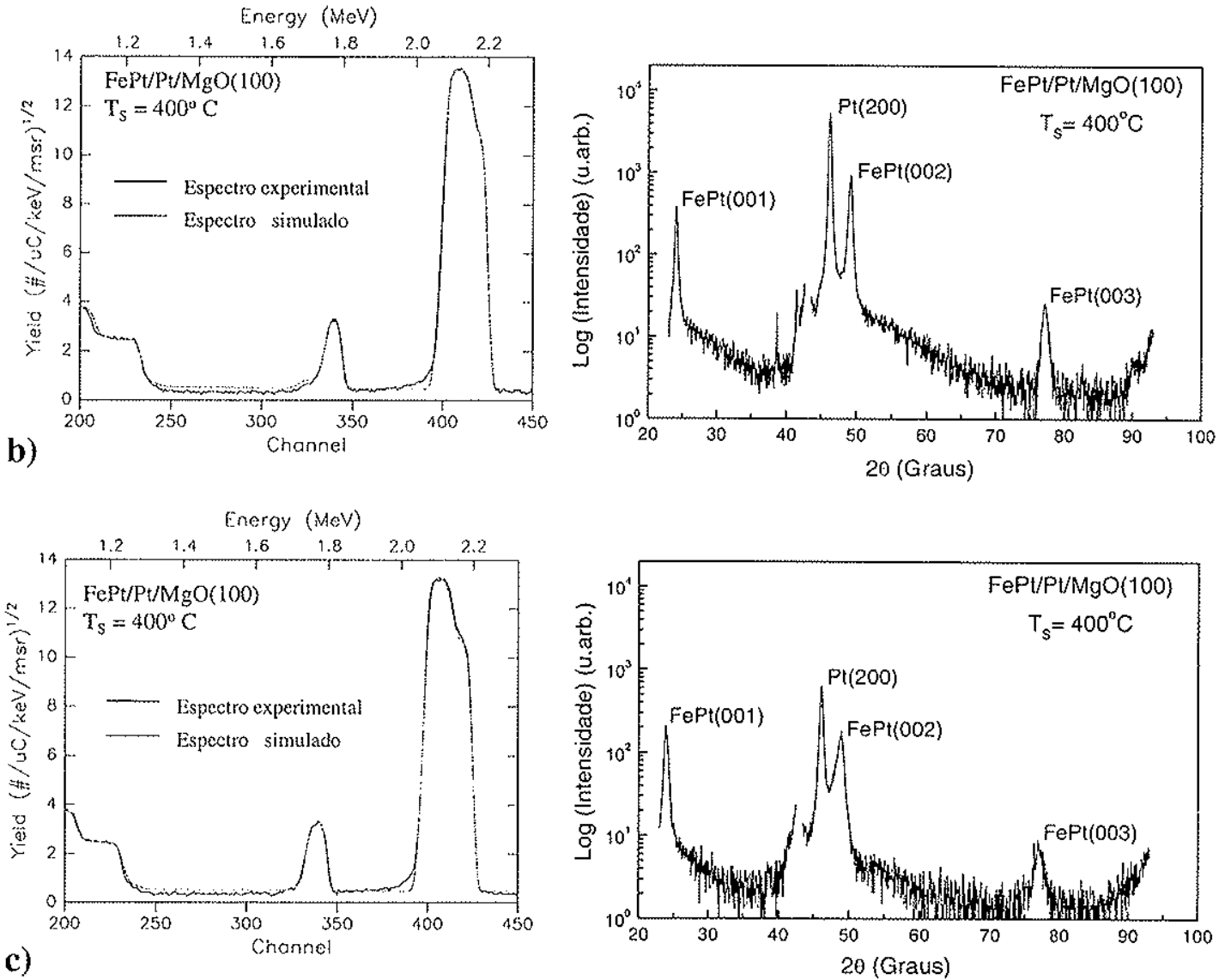

Fig. 5.22 - Espectros de RBS, com respectivas simulações, e difratogramas de XRD para filmes de FePt crescidos sobre $\mathrm{Pt} / \mathrm{MgO}(100)$, em pressões de deposição de (a) 2 , (b) 5 e (c) 10 mTorr.

etapas seguintes de preparação de filmes de FePt, sobre vários tipos de substratos e em diferentes valores de $\mathrm{T}_{S}$, pelo método de DAM, utilizamos os parâmetros obtidos nesse estudo preliminar.

Com a preparação de novos filmes de FePt através do método de DAM e a consequiente caracterização estrutural e magnética dos mesmos, buscamos determinar com maior clareza a eficiência deste método de deposição. Os filmes de FePt foram depositados 
sobre substratos de $\mathrm{MgO}(100)$ e $\mathrm{SiO}_{2}$, com e sem uma camada pré-depositada de um "buffer" de Pt $(\sim 65 \mathrm{~nm})$. Para a produção das amostras com o "buffer" foram seguidos dois diferentes procedimentos. No procedimento 1, o "buffer" e a camada FePt foram depositados na mesma temperatura do substrato $\left(\mathrm{T}_{S}\right)$. No procedimento 2 , o "buffer" foi pré-depositado em alta temperatura $\left(\mathrm{T}_{\mathrm{S}}=500^{\circ} \mathrm{C}\right)$, seguido pela deposição da camada FePt em diferentes $\mathrm{T}_{\mathrm{S}} . \mathrm{Em}$ todas as amostras, a camada FePt foi depositada em $\mathrm{T}_{S}$ variando de $200^{\circ} \mathrm{C}$ a $400^{\circ} \mathrm{C}$. Análises de RBS revelam a existência de filmes de FePt com concentrações atômicas de cada elemento de aproximadamente $50 \%$. Os filmes produzidos fazem parte das séries 8,9 e 10, cujas propriedades são apresentadas nas Tabelas 5.1 e 5.2 .

Na Figura 5.23 são apresentados difratogramas de XRD e curvas de histerese obtidos para os filmes de FePt depositados diretamente sobre substratos de MgO. Estes dados mostram a formação da estrutura $\mathrm{FCT}$ em $\mathrm{T}_{\mathrm{S}} \geq 200^{\circ} \mathrm{C}$. Em $\mathrm{T}_{\mathrm{S}}=200^{\circ} \mathrm{C}$, o respectivo difratograma de XRD mostra a presença de um pico largo de difração em $2 \theta=47.7^{\circ}$, relatado como sendo, em sua maior parte, ao pico FePt(200) da fase estrutural desordenada FCC(100) e, provavelmente, em menor parte, ao pico $\mathrm{FePt}(002)$ da fase ordenada $\mathrm{FCT}(001)$. As curvas de histerese mostram pequenas diferenças entre as propriedades magnéticas existentes nas duas geometrias, provavelmente devido a presença de uma mistura de fases estruturais no filme. Para o filme depositado em $\mathrm{T}_{\mathrm{S}}=300^{\circ} \mathrm{C}$, os dados de XRD mostram a presença de pequenos picos de difração de super-rede FePt(001) e (003), além do pico FePt(002) sobreposto ao pico $\mathrm{FePt}(200)$ da estrutura FCC, indicando uma maior evolução da fase FCT(001) em relação a fase $\mathrm{FCC}(100)$. Para este filme, o parâmetro de videnamento químico de longo alcance encontrado é de $S=0,29$. Suas curvas de histerese mostram, também, a ausência de uma direção preferencial de fácil magnetização, indicando a inexistência de uma anisotropia magnética, devido à mistura de fases. No difratograma do filme depositado em $\mathrm{T}_{\mathrm{S}}=400^{\circ} \mathrm{C}$, a presença de picos de difração $\mathrm{FePt}(001)$ e (003) de maiores intensidades evidencia a forte presença da fase $\mathrm{FCT}(001)$, apesar de que ainda existe uma pequena parcela de cristalitos com a fase FCC(100). Para este filme, um valor de $S=0,32$ foi encontrado. Suas respectivas curvas de histerese revelam a presença de anisotropia magnética perpendicular, indicando predominância da fase $\mathrm{FCT}(001)$. Os valores de campo coercivo medidos na geometria perpendicular $\left(H c_{\perp}\right)$ variam de 0.36 para $1.63 \mathrm{kOe}$ com o aumento de $\mathrm{T}_{\mathrm{S}}$, devido ao aumento do grau de ordenamento químico dos filmes.

Os resultados obtidos com o crescimento de filmes de FePt diretamente sobre substratos de $\mathrm{MgO}$, utilizando o método de DAM, revelam a possibilidade de obtenção da 

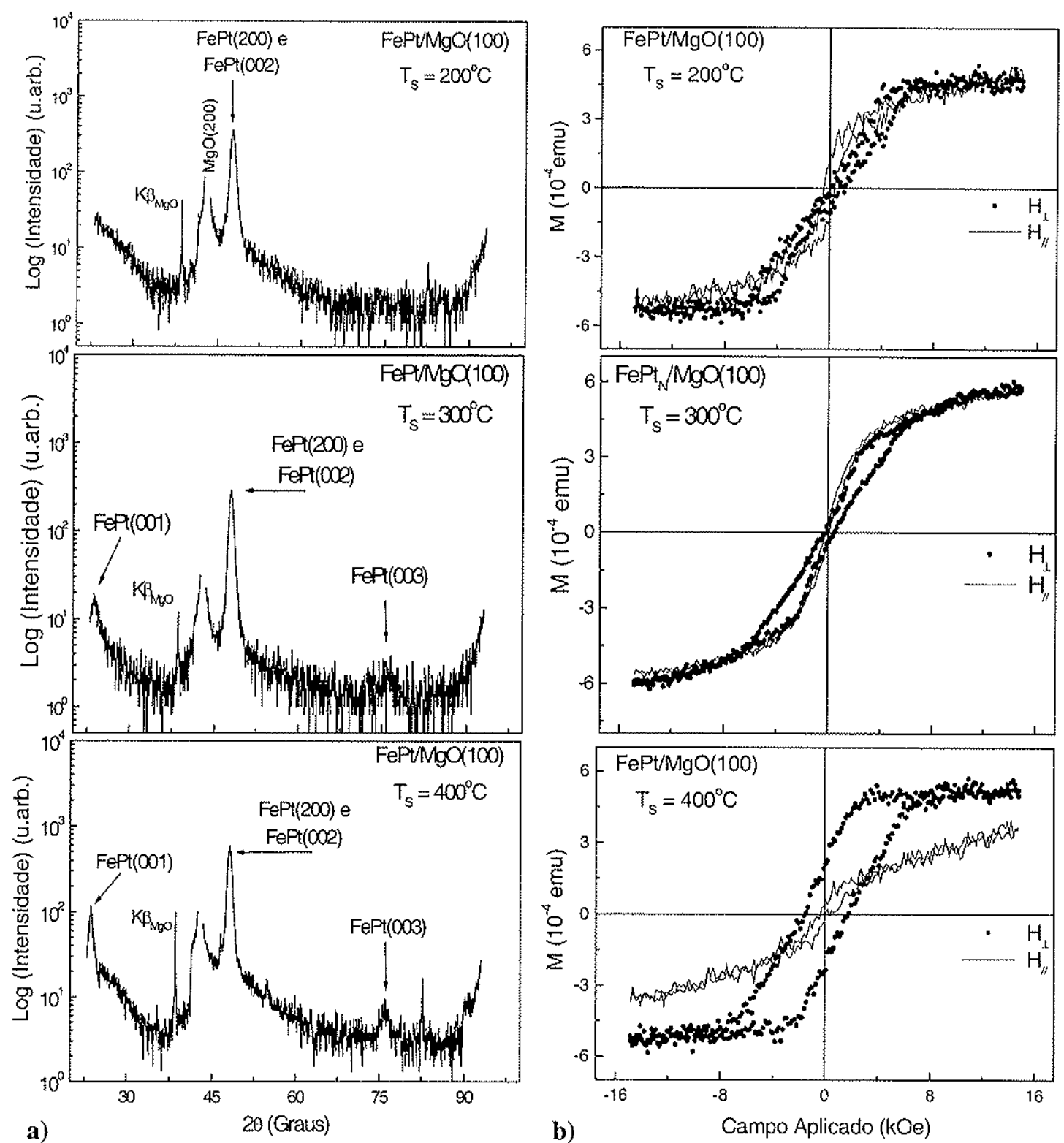

Fig. 5.23 - (a) Difratogramas de XRD e (b)curvas de histerese obtidas para filmes de FePt crescidos por DAM sobre substratos de $\mathrm{MgO}(100)$.

fase estrutural FePt $\mathrm{FCT}(001)$ com deposições realizadas em $\mathrm{T}_{\mathrm{S}}=400^{\circ} \mathrm{C}$, diferentemente do método de codeposição, onde em $\mathrm{T}_{\mathrm{S}}=400^{\circ} \mathrm{C}$ somente a fase $\mathrm{FCC}(100)$ pôde ser obtida para o filme de FePt.

Para os filmes de FePt depositados sobre substratos de $\mathrm{MgO}$ com um "buffer" de Pt, seguindo o procedimento 1 , os dados de XRD e curvas de histerese mostram a formação da fase $\mathrm{FCT}(001)$ na amostra depositada em $\mathrm{T}_{\mathrm{S}} \geq 300^{\circ} \mathrm{C}$ (Fig.5.24). Para $\mathrm{T}_{\mathrm{S}}=200^{\circ} \mathrm{C}$, picos de difração FePt(111) e (222) evidenciam a presença de somente uma fase FCC(111), o qual é devido ao crescimento "epitaxial" induzido dos grãos da camada FePt sobre o "buffer" de Pt com uma predominante fase estrutural FCC(111). A fase FePt FCC(111) produz anisotropia magnética no plano e relativamente baixa coercividade $(\sim 0.5 \mathrm{kOe})$ em ambas geometrias. Em 

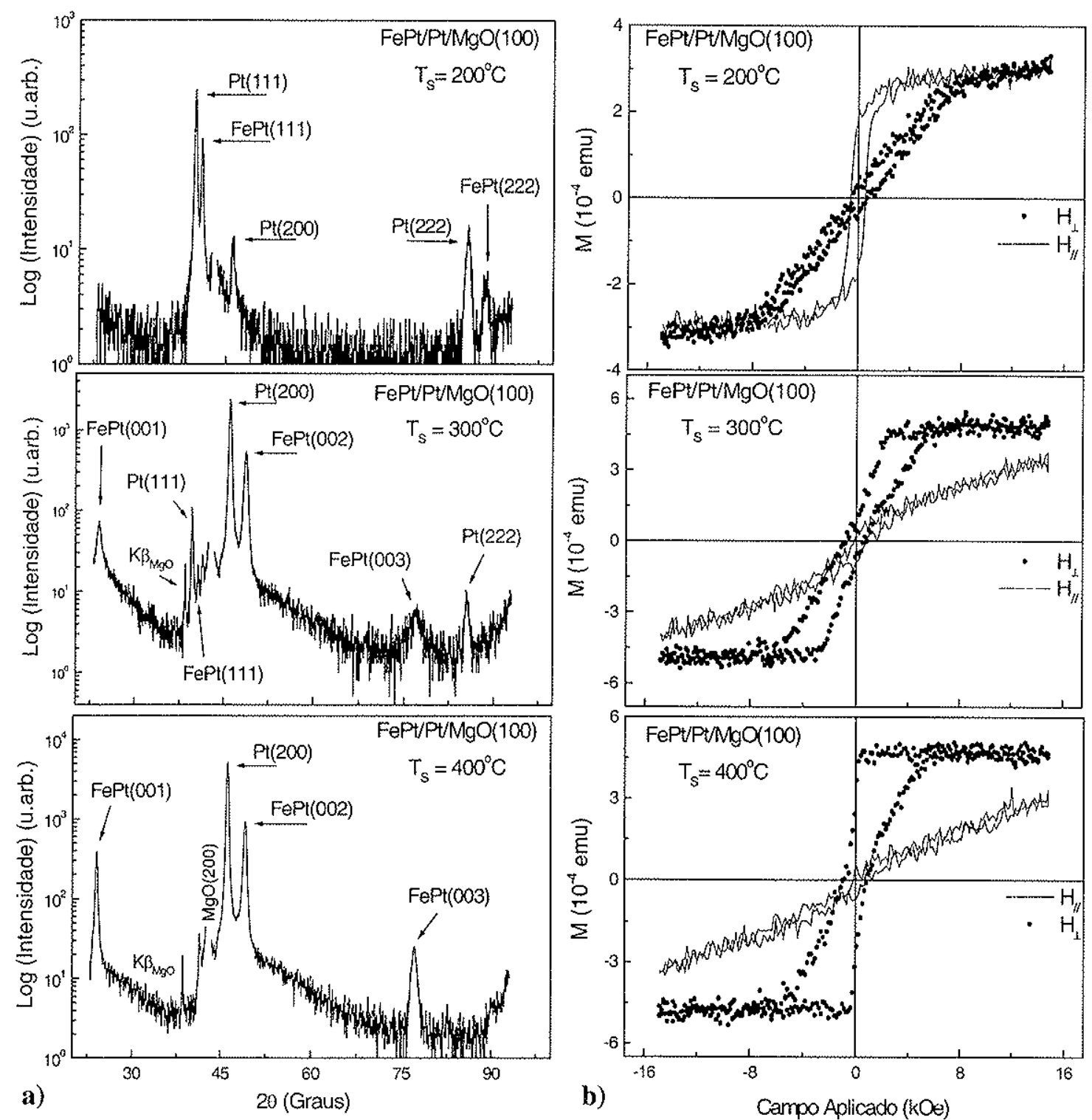

Fig. 5.24 - (a) Difratogramas de XRD e (b) curvas de histerese obtidas para filmes de FePt crescidos por DAM sobre substratos de $\mathrm{Pt} / \mathrm{MgO}(100)$, de acordo com o procedimento 1 .

$\mathrm{T}_{\mathrm{S}}=300^{\circ} \mathrm{C}$, a presença de picos de difração FePt $(001),(002)$ e $(003)$ revelam a presença da fase FCT(001) na liga. Para este filme, $S=0.33$ foi obtido. Porém, a presença de um pequeno pico de difração FePt(111) indica a existência de uma certa quantidade de cristalitos com a fase estrutural FCC(111), provavelmente induzidos "epitaxialmente" por alguns cristalitos do "buffer" com textura [111]. Entretanto, em $\mathrm{T}_{\mathrm{S}}=400^{\circ} \mathrm{C}$, a existência dos picos de difração FePt(001), (002) e (003), com alta intensidade, revelam a presença de um filme de FePt com predominate fase $\mathrm{FCT}(001)$. O valor de $S$ para este filme é de 0.53 , indicando bom ordenamento químico. As curvas de histerese dos filmes depositados $\mathrm{em} \mathrm{T}_{S} \geq 300^{\circ} \mathrm{C}$ mostram a presença de anisotropia magnética perpendicular e valores de $H c_{\perp}$ variando de 0.73 para $0.90 \mathrm{kOe}$, com o crescimento de $\mathrm{T}_{\mathrm{S}}$, devido ao aumento do grau de ordenamento químico. 

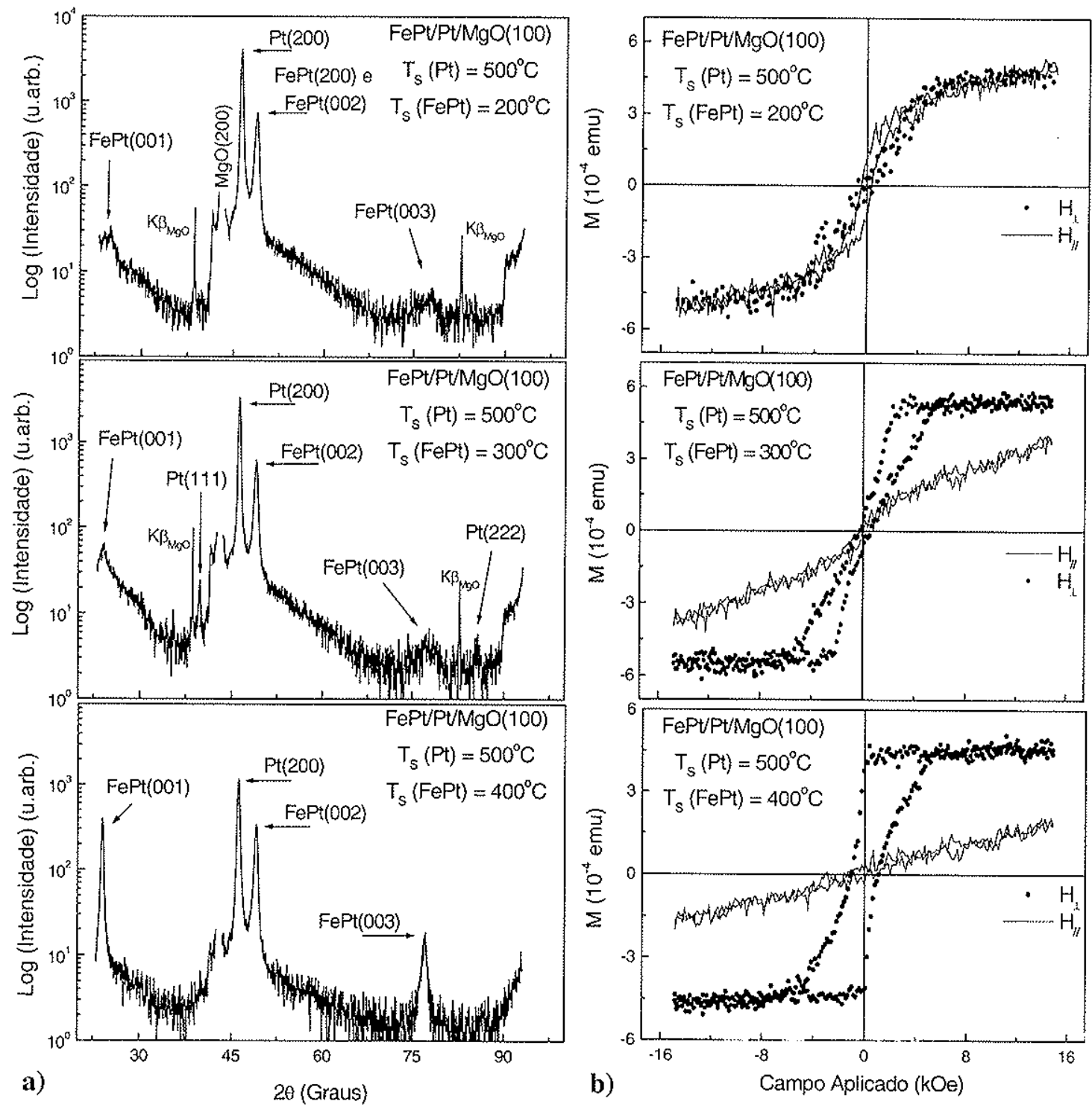

Fig. 5.25 - (a) Difratogramas de XRD e (b) curvas de histerese obtidas para filmes de FePt crescidos por DAM sobre substratos de $\mathrm{Pt} / \mathrm{MgO}(100)$, de acordo com o procedimento 2 .

Para os filmes de FePt crescidos sobre substratos de $\mathrm{MgO}$ com um "buffer" de Pt, seguindo o procedimento 2 , a formação da fase FCT(001) foi observada em todas temperaturas, conforme pode ser visto pelos resultados de XRD e curvas de histerese dessas amostras (Fig.5.25). Em $\mathrm{T}_{\mathrm{S}}=200^{\circ} \mathrm{C}$, os dados de XRD mostram a presença de pequenos picos de super-rede. Um pico em $48,66^{\circ}$, pode ser correlacionado como uma superposição entre os picos de difração FePt(200), da fase FCC(100), e FePt(002), da fase FCT(001). As curvas de histerese dessa amostra exibem pequenas diferenças entre as propriedades magnéticas existentes nas duas geometrias, provavelmente devido a presença de uma mistura de fases 
estruturais. Para $\mathrm{T}_{S} \geq 300^{\circ} \mathrm{C}$, a evolução dos picos de super-rede indicam um aumento do grau de ordenamento químico. O parâmetro $S$ varia de 0,16 para 0,88 com o crescimento de $T_{S}$. Em $\mathrm{T}_{\mathrm{S}}=300^{\circ} \mathrm{C}$, alguns cristalitos do "buffer" de Pt com a fase FCC(111), decorrentes de prováveis flutuações ocorridas durante o processo de deposição, provocaram uma redução do grau de ordenamento químico da camada FePt. Para $\mathrm{T}_{S} \geq 300^{\circ} \mathrm{C}$, verifica-se a presença de anisotropia magnética perpendicular. Os valores de $\mathrm{Hc}_{\perp}$, para todas as amostras, variam de 0.51 para $1.03 \mathrm{kOe}$ com o crescimento de $\mathrm{T}_{S}$, devido ao aumento do grau de ordenamento químico. Esses resultados revelam que a utilização de uma camada "buffer" de Pt com uma estrutura FCC e somente uma textura [100] (depositada em alto $\mathrm{T}_{\mathrm{S}}$ ) torna possível o crescimento de um filme de FePt com uma estrutura FCT, em menor temperatura do substrato, e um melhor ordenamento químico em $\mathrm{T}_{\mathrm{S}}=400^{\circ} \mathrm{C}$.

Para filmes de FePt crescidos sobre substratos de $\mathrm{SiO}_{2}$, com e sem o "buffer" de Pt, os resultados de XRD (Fig. 5.26) mostram que apenas a fase quimicamente desordenada FePt FCC(111) é formada no filme, mesmo com deposições realizadas em $\mathrm{T}_{S}=400^{\circ} \mathrm{C}$. Com esse resultado verificamos que a eficiência do método de DAM é fortemente correlacionado com os efeitos de um crescimento "epitaxial" induzido do filme. Na ausência de condições que permitem um crescimento induzido do filme, como é o caso do uso de substratos de $\mathrm{SiO}_{2}$, os efeitos de minimização da energia livre de superfície são dominantes na formação da fase estrutural do filme.

Na tabela 5.8 são apresentados valores de tamanho médio do grão cristalino $\left(D_{h k l}\right)$, parâmetro de ordenamento químico de longo alcance $(S)$ e campo coercivo perpendicular $\left(H_{C . l}\right)$, para os filmes de FePt estudados neste trabalho (por codeposição e DAM) que apresentam a fase $\mathrm{FCT}(001)$. É possível verificar que a amostra S10D-C preparada por DAM
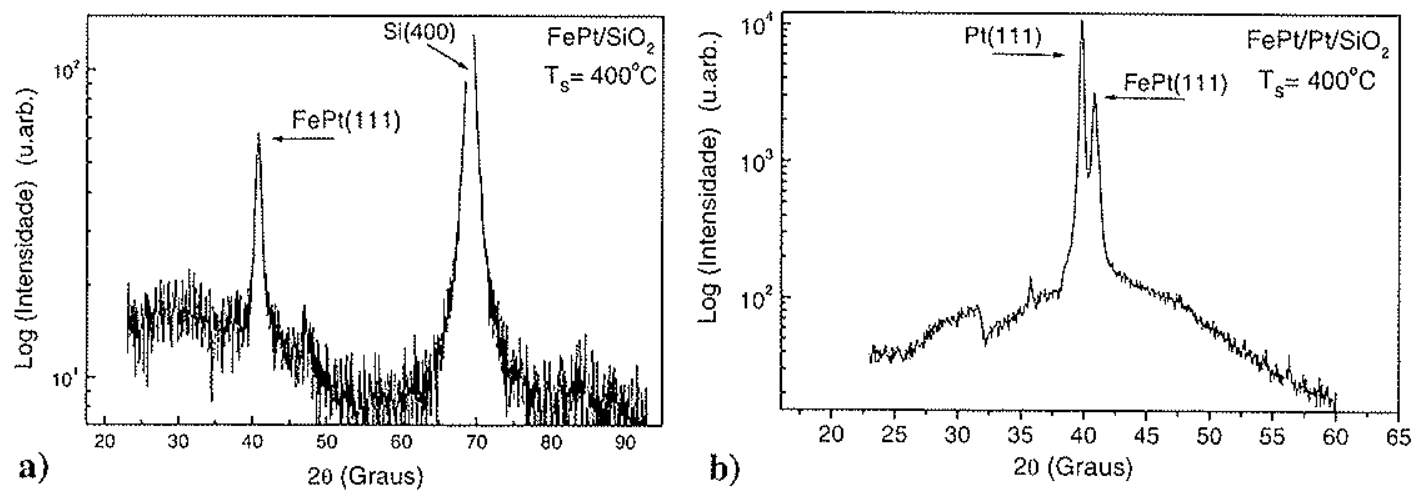

Fig. 5.26 - Difratogramas de XRD de filmes de FePt crescidos por DAM sobre substratos de (a) $\mathrm{SiO}_{2}$ e (b) $\mathrm{Pt} / \mathrm{SiO}_{2}$. 
Tabela 5.8 - Valores de tamanho médio do grão cristalino $\left(D_{h k l}\right)$, parâmetro de ordenamento químico de longo alcance $(S)$ e campo coercivo perpendicular $\left(H_{C L}\right)$, para os filmes de FePt que apresentam a fase estrutural FCT(001).

\begin{tabular}{|c|c|c|c|c|c|c|c|}
\hline Amostra & $\begin{array}{c}\text { Método de } \\
\text { Deposição }\end{array}$ & $\begin{array}{c}T_{S}\left({ }^{\circ} \mathrm{C}\right) \\
(\text { Pt/FePt })\end{array}$ & ${ }^{*}$ Composição & $\begin{array}{c}\text { Espessura } \\
(\text { nm }) \\
(\text { FePt/Pt })\end{array}$ & $\begin{array}{c}D_{001} \\
(\text { nm })\end{array}$ & $S$ & $\begin{array}{c}H_{C \perp} \\
(k O e)\end{array}$ \\
\hline S3C-D & codeposição & $-/ 600$ & $\mathrm{Fe}_{0.52} \mathrm{Pt}_{0.48}$ & $115 /-$ & 51,8 & 0,84 & 1,00 \\
\hline S6C-B & codeposição & $400 / 400$ & $\mathrm{Fe}_{0.51} \mathrm{Pt}_{0.49} / \mathrm{Pt}$ & $105,1 / 76$ & 29,1 & 0,40 & 1,34 \\
\hline S6C-C & codeposição & $500 / 500$ & $\mathrm{Fe}_{0.51} \mathrm{Pt}_{0.49} / \mathrm{Pt}$ & $103,5 / 70$ & 34,6 & 0,65 & 1,25 \\
\hline S7C-E & codeposição & $300 / 300$ & $\mathrm{Fe}_{0.46} \mathrm{Pt}_{0.49} \mathrm{R}_{0.06} / \mathrm{Pt}$ & $34 / 50$ & 19,4 & 0,45 & 1,70 \\
\hline S7C-H & codeposição & $300 / 500$ & $\mathrm{Fe}_{0.47} \mathrm{Pt}_{0.47} \mathrm{R}_{0.06} / \mathrm{Pt}$ & $32 / 50$ & 25,6 & 0,78 & 1,20 \\
\hline S7C-D & codeposição & $500 / 300$ & $\mathrm{Fe}_{0.48} \mathrm{Pt}_{0.47} \mathrm{R}_{0.05} / \mathrm{Pt}$ & $34 / 50$ & 20,0 & 0,46 & 0,80 \\
\hline S7C-I & codeposição & $500 / 500$ & $\mathrm{Fe}_{0.47} \mathrm{Pt}_{0.47} \mathrm{R}_{0.06} / \mathrm{Pt}$ & $32 / 50$ & 25,7 & 0,80 & 0,75 \\
\hline S9D-B & DAM & $-/ 300$ & $\mathrm{Fe}_{0.42} \mathrm{Pt}_{0.48} \mathrm{R}_{0.10}$ & $36 /-$ & 5,08 & 0,30 & 0,37 \\
\hline S9D-C & DAM & $-/ 400$ & $\mathrm{Fe}_{0.46} \mathrm{Pt}_{0.48} \mathrm{R}_{0.06}$ & $35 /-$ & 13,6 & 0,32 & 1,63 \\
\hline S9D-E & DAM & $300 / 300$ & $\mathrm{Fe}_{0.42} \mathrm{Pt}_{0.48} \mathrm{R}_{0.10} / \mathrm{Pt}$ & $36 / 66$ & 11,8 & 0,33 & 0,73 \\
\hline S9D-F & DAM & $400 / 400$ & $\mathrm{Fe}_{0.47} \mathrm{Pt}_{0.53} \mathrm{R}_{0.06} / \mathrm{Pt}$ & $35 / 65$ & 23,1 & 0,53 & 0,90 \\
\hline S10D-A & DAM & $500 / 200$ & $\mathrm{Fe}_{0.45} \mathrm{Pt}_{0.46} \mathrm{R}_{0.09} / \mathrm{Pt}$ & $37 / 65$ & 7,3 & 0,16 & 0,51 \\
\hline S10D-B & DAM & $500 / 300$ & $\mathrm{Fe}_{0.45} \mathrm{Pt}_{0.46} \mathrm{R}_{0.09} / \mathrm{Pt}$ & $37 / 65$ & 14,4 & 0,20 & 0,14 \\
\hline S10D-C & DAM & $500 / 400$ & $\mathrm{Fe}_{0.45} \mathrm{Pt}_{0.46} \mathrm{R}_{0.09} / \mathrm{Pt}$ & $37 / 65$ & 25,0 & 0,88 & 1,03 \\
\hline
\end{tabular}

Filmes crescidos sobre substratos de $\mathrm{MgO}(100)$.

$\mathrm{R}=$ Contaminantes

na codição $\mathrm{T}_{S}(\mathrm{Pt} / \mathrm{FePt})=500 / 400^{\circ} \mathrm{C}$ apresenta o maior valor do parâmetro $S$ em comparação com as outras amostras. Com relação ao tamanho médio do grão cristalino, podemos verificar que os filmes de FePt mais espessos apresentam os maiores valores. Para estes casos, o valor de $D_{h k l}$ cresce com o aumento de $\mathrm{T}_{\mathrm{S}}$ da camada FePt. Para os filmes menos espessos e qui posuem os maiores valores de $S$, os valores de $D_{h k l}$ são muito próximos. Em relação ao campo coercivo $H c_{L}$, é possível verificar valores de $\sim 1 \mathrm{kOe}$ para os filmes de FePt com os maiores valores de $S$ (maior grau de ordenamento químico).

Os resultados alcançados mostram que, em termos da obtenção de um filme de FePt com a fase FCT(001) e alto grau de ordenamento químico, com deposições em reduzido valor de $\mathrm{T}_{S}$, o método de DAM é mais eficaz do que o método de codeposição. Esta afirmação pode ser entendida da seguinte maneira: no crescimento do filme por deposição simultânea de elementos químicos, a temperatura do substrato é um fator importante no processo de ordenamento químico. A transferência de energia térmica aos átomos recém depositados sobre o substrato proporciona aos mesmos maior mobilidade atômica superficial. Essa maior mobilidade permite aos átomos se rearranjarem formando uma estrutura quimicamente ordenada. Por outro lado, com o crescimento de monocamada por monocamada atômica de 
cada elemento químico, o processo de ordenamento é automaticamente gerado. Como não trabalhamos com condições ideais (atmosfera de UHV e átomos incidentes sobre o substrato com baixa energia), o processo fica ainda dependente da temperatura do substrato, porém em menor escala quando comparado ao método de codeposição. Outro fator importante também verificado, é o fato da eficiência do método de DAM ser dependente da utilização de um substrato com uma estrutura favorável para permitir um crescimento "epitaxial" induzido do filme.

\subsection{Medidas de XAS em Filmes de FePt}

Com a utilização da técnica de Espectroscopia de Absorção de Raios-X (XAS), buscamos a obtenção de informações complementares sobre a estrutura dos filmes de FePt produzidos. Com este estudo tivemos a oportunidade de verificar também a qualidade dos filmes produzidos.

Foram analisadas três amostras: duas com predominante fase estrutural FePt FCT(001) (depositadas por codeposição e DAM) e uma com predominante fase FCC $(100)$ (codeposição). As características das amostras analisadas por XAS são apresentadas na Tabela 5.9.

Com o propósito de obtenção de informações seletivas sobre as diferentes orientações do filme, adotamos o procedimento de realizar, para os filmes de FePt com a fase FCT(001), medidas de XAS em função da polarização do vetor campo elétrico (E) da radiação incidente. As respectivas medidas foram realizadas ajustando-se o ângulo $(\theta)$ que define a direção da radiação incidente com relação à normal ao plano do filme para valores de $15^{\circ}, 36^{\circ}$ e $75^{\circ}$

Tabela 5.9 - Características das amostras analisadas por XAS.

\begin{tabular}{|c|c|c|c|c|c|}
\hline Amostra & $\begin{array}{l}\text { Método de } \\
\text { Deposição }\end{array}$ & Composição & $\begin{array}{c}\text { Espessura } \\
(\mathrm{FePt} / \mathrm{Pt})\end{array}$ & $\begin{array}{c}{ }^{\#} \text { Estrutura } \\
\text { predominante }\end{array}$ & $\begin{array}{l}\text { Textura } \\
\text { principal }\end{array}$ \\
\hline $\begin{array}{l}\text { S7C-B } \\
(\mathrm{FCC})\end{array}$ & codeposição & $\begin{array}{c}\mathrm{Fe}_{0.48} \mathrm{Pt}_{0.47} \mathrm{R}_{0.05} / \\
\mathrm{Pt} / \mathrm{MgO}(100)\end{array}$ & $34 / 50$ & $\mathrm{FCC}$ & {$[100]$} \\
\hline $\begin{array}{l}\text { S7C-I } \\
\text { (FCT1) }\end{array}$ & codeposição & $\begin{array}{c}\mathrm{Fe}_{0.47} \mathrm{Pt}_{0.47} \mathrm{R}_{0.06} / \\
\mathrm{Pt} / \mathrm{MgO}(100)\end{array}$ & $32 / 50$ & FCT & {$[001]$} \\
\hline $\begin{array}{l}\text { S10D-C } \\
\text { (FCT2) }\end{array}$ & DAM & $\begin{array}{c}\mathrm{Fe}_{0.45} \mathrm{Pt}_{0.46} \mathrm{R}_{0.09} / \\
\mathrm{Pt} / \mathrm{MgO}(100)\end{array}$ & $37 / 65$ & FCT & {$[001]$} \\
\hline
\end{tabular}


(ver esquema na Fig.4.9). Em $\theta=15^{\circ}$, o vetor E é orientado muito próximo ao plano do filme, o que permite investigar as características da vizinhança do átomo absorvedor, no plano da amostra. Para um filme de FePt com uma estrutura FCT $\left(\mathrm{L} 1_{0}\right)$ pura, existe uma maior vizinhança de átomos de Fe-Fe e Pt-Pt na geometria no plano. Diferentemente, em $\theta=75^{\circ}$, o vetor $\mathrm{E}$ é orientado próximo a direção perpendicular ao plano do filme, possibilitando a sondagem das características da vizinhança na direção normal ao plano da amostra. Em um filme de FePt com uma estrutura FCT (L10) pura, a vizinhança do tipo Fe-Pt é maior na geometria perpendicular do que no plano do filme. Estas diferenças no número de vizinhos $\mathrm{Fe}-\mathrm{Fe}$ e Fe-Pt nas duas geometrias são devido ao fato dessa estrutura possuir um ordenamento quimico unidirecional. $\operatorname{Em} \theta=36^{\circ}$, a orientação do vetor $E$ permite a obtenção de informações sobre a vizinhança que representam em conjunto as duas geometrias. A configuração $\theta=36^{\circ}$ foi utilizada na medida de XAS do filme de FePt com a fase predominante $\mathrm{FCC}(100)$.

Foram realizadas simulações padrão de XANES e EXAFS para estruturas teóricas de:

- $\mathbf{F e P t}_{3}(\mathbf{F C C})$ - Fe na origem e Pt nas faces da cela unitária.

$1^{\underline{\text { os }}}$ vizinhos em torno do átomo absorvedor: $12 \mathrm{Pt}$ (distância $=2.698 \AA$ )

- $\mathbf{F e}_{3} \mathbf{P t}(\mathbf{F C C})$ - Pt na origem e Fe nas faces da cela unitária.

$1^{\mathrm{os}}$ vizinhos em torno do átomo absorvedor: $8 \mathrm{Fe}, 4 \mathrm{Pt}($ distância $=2.698 \AA$ )

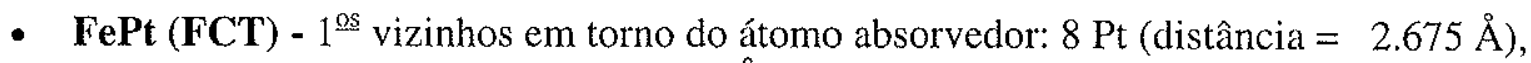
$4 \mathrm{Fe}($ distância $=2.733 \AA)$

\subsubsection{Análises de XANES}

Na Figura 5.27(a) é apresentada uma superposição de espectros de XANES obtidos através de simulações para estruturas teóricas de $\mathrm{Fe}_{3} \mathrm{Pt}, \mathrm{FePt}_{3}$ (ambas com estrutura $\mathrm{FCC}$ ) e $\mathrm{Fe}$ puro (BCC). É possivel verificar a presença de três picos após a borda de absorção nos espectros simulados para as estruturas $\mathrm{Fe}_{3} \mathrm{Pt}$ e $\mathrm{FePt}_{3}$. O espectro da estrutura $\mathrm{Fe}_{3} \mathrm{Pt}$ mostra que os picos a e b possuem, basicamente, a mesma intensidade e o pico $\mathbf{c}$ a maior largura. Para a estrutura $\mathrm{FePt}_{3}$, a simulação nos mostra que o pico a possui maior intensidade quando comparado com o pico b. Na simulação de XANES para o Fe padrão, verificamos a ausência de picos semelhantes aos obtidos nas simulações para o $\mathrm{Fe}_{3} \mathrm{Pt}$ e $\mathrm{FePt}_{3}$. As informações obtidas com as simulações teóricas de XANES revelam que os picos $\mathbf{a}$ e $\mathbf{b}$ são fortemente correlacionados com a estrutura FCC. De outro modo, o pico $\mathbf{c}$ refere-se a primeira oscilação 


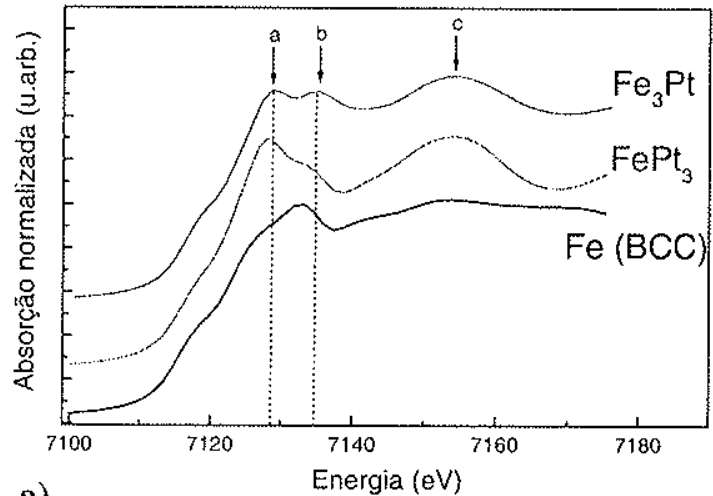

a)

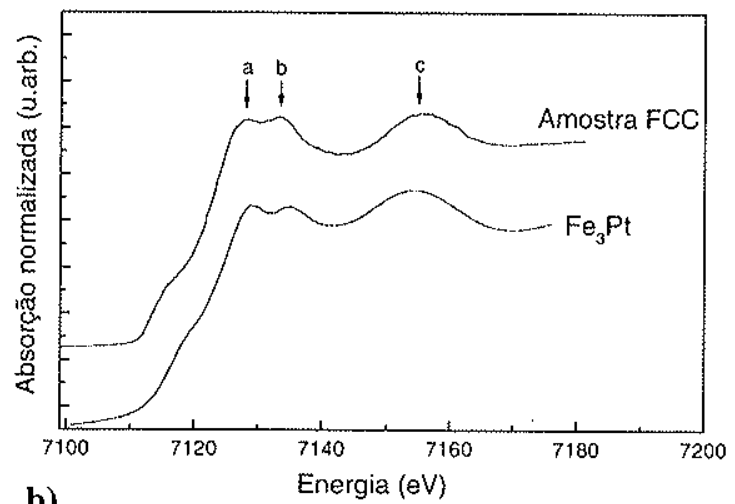

b)

Fig. 5.27 - (a) Superposição de espectros de XANES obtidos através de simulações teóricas para vários tipos de estruturas. (b) Superposição de espectros de XANES da amostra $\mathrm{FCC}$ e da estrutura $\mathrm{Fe}_{3} \mathrm{Pt}$.

de EXAFS. Na Figura 5.27(b) são apresentados sobrepostos, o espectro de XANES da estrutura teórica $\mathrm{Fe}_{3} \mathrm{Pt}$ e da amostra $\mathrm{FCC}$, onde é possível verificar grande semelhança entre os respectivos espectros.

Na Figura 5.28(a), é apresentado uma superposição de espectros de XANES, obtidos através de simulações teóricas para uma estrutura FePt do tipo $\mathrm{L} 1_{0}$ (FCT), com a orientação do vetor $E$ variando de uma direção no plano $\left(\theta=0^{\circ}\right)$ até uma condição perpendicular ao plano do filme $\left(\theta=90^{\circ}\right)$. Analisando os espectros é possível verificar um crescimento progressivo do pico a com o aumento do ângulo $\theta$. Estes resultados revelam que o pico a é correlacionado com a vizinhança de Pt e o pico b à vizinhança de Fe, com relação ao átomo absorvedor. Na configuração $\theta=90^{\circ}$ (onde o pico a possui maior intensidade) a sensibilidade a um maior número de átomos primeiros vizinhos de Fe-Pt torna-se evidente, para uma estrutura químicamente ordenada FePt FCT. Na Figura 5.28 (b) e (c), é apresentado uma superposição de espectros experimentais de XANES das amostras FCT1 e FCT2, obtidos sobre valores de $\theta$ de $15^{\circ}, 36^{\circ}$ e $75^{\circ}$. É possível verificar que os espectros das duas amostras são muito semelhantes. Em todos os casos verificamos a presença dos picos $\mathbf{a}, \mathbf{b}$ e $\mathbf{c}$. Na configuração $\theta$ $=75^{\circ}$, é possível verificar que o pico a possui maior intensidade, quando comparado com o pico b. De outro modo, em $\theta=15^{\circ}$, o pico b se apresenta ligeiramente com maior intensidade em relação ao pico a. Para estas amostras, os resultados obtidos através de medidas de XAS em função da polarização mostram que a estrutura de ordem local apresenta características diferentes na geometria no plano e perpendicular ao plano do filme, porém em menor proporção, quando comparados com os resultados obtidos através das simulações para uma estrutura teórica (Fig. 5.28(a)). Vários são os fatores que podem reduzir os efeitos da polarização como a presença de desordem estrutural, textura e desordem química 

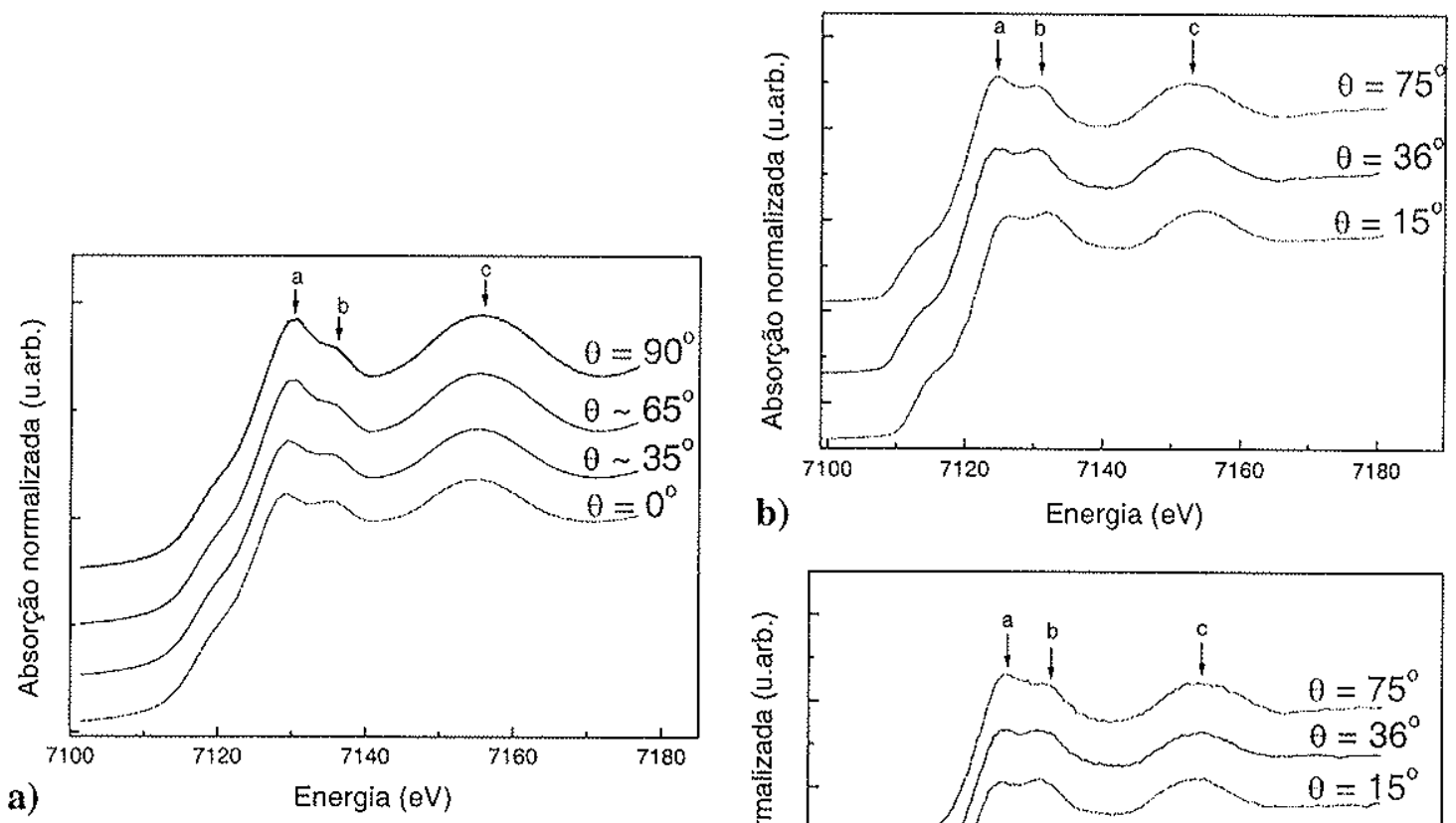

b)

Energia (eV)

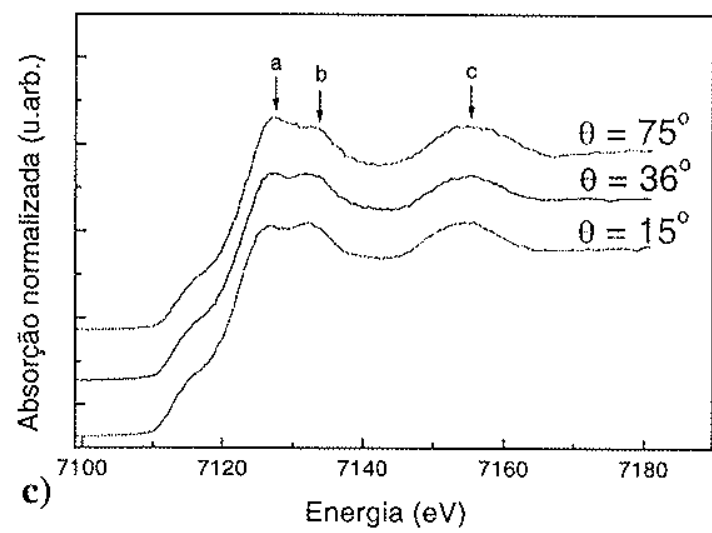

Fig. 5.28 - (a) Superposição de espectros de XANES, obtidos através de simulações teóricas para uma estrutura tipo L1o (FCT), com a polarização do campo $E$ variando de uma direção no plano $\left(\theta=0^{\circ}\right)$ ate uma condição perpendicular ao plano do filme $\left(\theta=90^{\circ}\right)$. Em (b) e (c), superposição de espectros de XANES das amostras (b) FCT1 e (c) FCT2, obtidos sobre valores de $\theta$ de $15^{\circ}, 36^{\circ}$ e $75^{\circ}$.

nas amostras. Porém, no caso das amostras FCT1 e FCT2, é possível que a presença de uma parcela de desordem química seja o fator principal. É provável que em certos planos cristalinos, átomos de $\mathrm{Fe}(\mathrm{Pt})$ tenham sido substituídos por átomos de $\mathrm{Pt}(\mathrm{Fe})$.

\subsubsection{Análises de EXAFS}

São apresentadas na Figura 5.29, as transformadas de Fourier dos espectros experimentais de EXAFS (obtidos na configuração $\theta=36^{\circ}$ ) das amostras analisadas por XAS. É possível verificar que as transformadas de Fourier das amostras FCT1 e FCT2 são muito semelhantes. Para a amostra FCC, pequenas diferenças nos picos $\beta, \gamma, \delta$, e $\varepsilon$ são observados, quando comparados com os mesmos das outras amostras. Na Figura 5.30, é apresentado uma 
superposição de transformadas de Fourier dos espectros experimentais de EXAFS da amostra FCT1, obtidos através de medidas de XAS sobre valores de $\theta$ de $15^{\circ}, 36^{\circ}$ e $75^{\circ}$. É possível observar pequenas diferenças entre as transformadas de Fourier obtidas com o campo $E$ orientado em diferentes direções. $\operatorname{Em} \theta=75^{\circ}$, os picos $\beta$ e $\gamma$, se apresentam com maior intensidade, quando comparado com as outras orientações. Pode-se verificar que o pico $\alpha$ possue um maior deslocamento para a esquerda em $\theta=75^{\circ}$ quando comparado com o mesmo pico em $\theta=15^{\circ}$. Em $\theta=36^{\circ}$, podemos verificar a presença de um pico $\alpha$ de menor intensidade e maior largura quando comparado com o mesmo das outras orientações, o que reflete o fato de que nessa orientação as informações sobre o número de vizinhos representa o conjunto das informações sobre as outras orientações. Portanto, essas diferenças observadas nas transformadas de Fourier exprimem bem as diferentes características da vizinhança de ordem local nas diferentes geometrias do filme, porém, numa escala menor ao que era de se esperar para uma estrutura FCT perfeita. A explicação para esse resultado se baseia no grau de ordenamento químico do filme. Conforme também verificado nas análises de XANES, é possível que essa amostra possua pequenas regiões com subtituição aleatória de átomos de $\mathrm{Fe}$

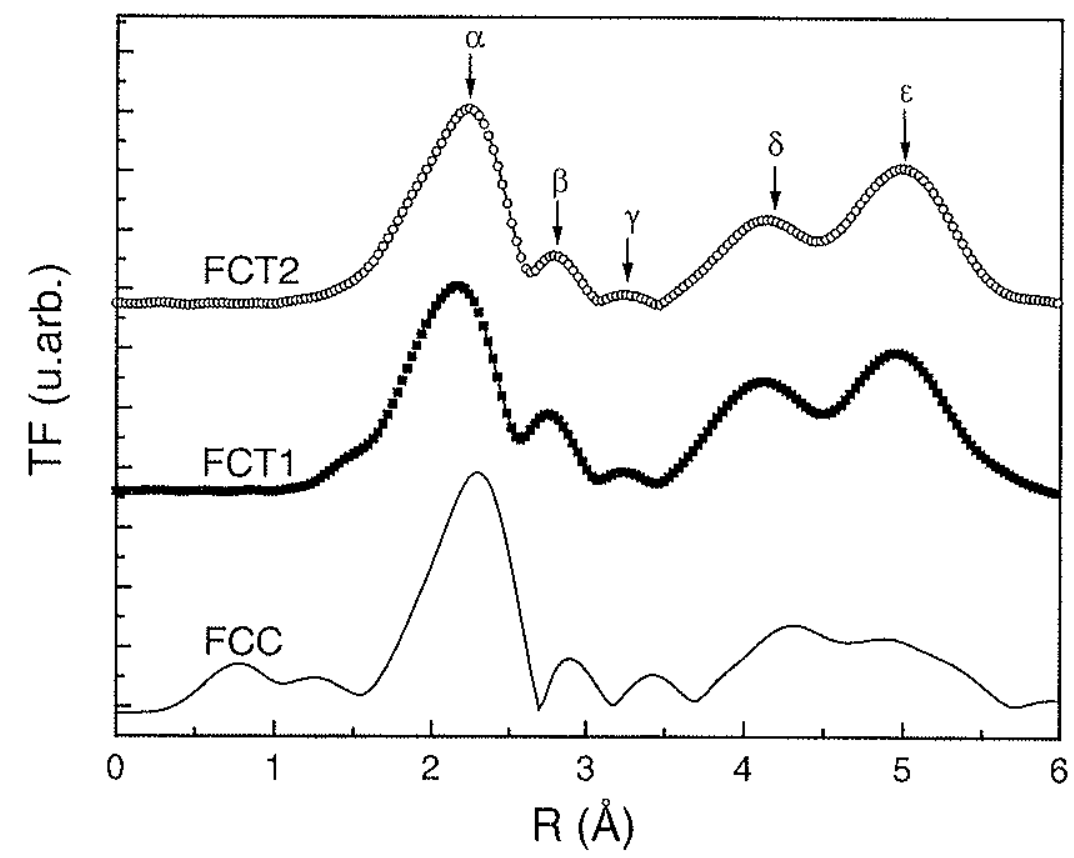

Fig. 5.29 - Transformadas de Fourier do espectro experimental de EXAFS das amostras analisadas por XAS. Medidas obtidas com o ângulo $(\theta)$ entre a radiação incidente e a normal ao plano do filme fixado em $36^{\circ}$. 


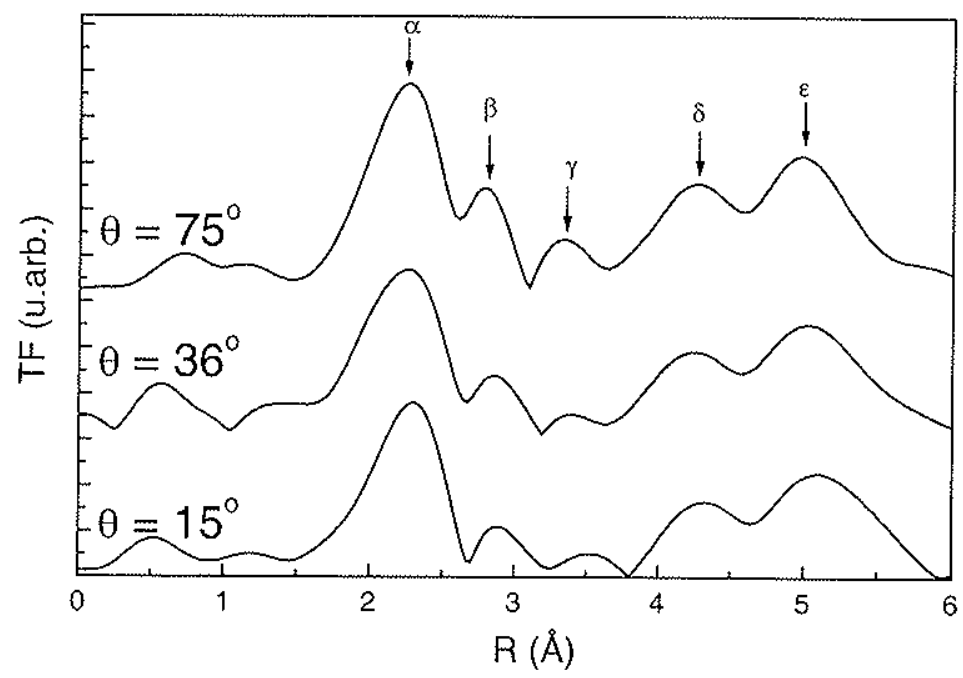

INSTITUTO DE FISICA Serviço de Biblioteca $\theta$ informacão

Fig. 5.30 - Superposição de transformadas de Fourier do espectro de EXAFS da amostra FCT1, obtidos através de medidas de XAS com o ângulo $(\theta)$ entre a radiação incidente e a normal ao plano do filme fixado em $15^{\circ}, 36^{\circ}$ e $75^{\circ}$.

e Pt. Porém, é importante citar que, para esse filme, as substituições atômicas apenas produzem alguns planos imperfeitos, não chegando a gerar cristalitos com estrutura FCC, conforme verificado nos dados de XRD. Para amostra FCT2, comportamento semelhante ao da amostra FCT1 é observado.

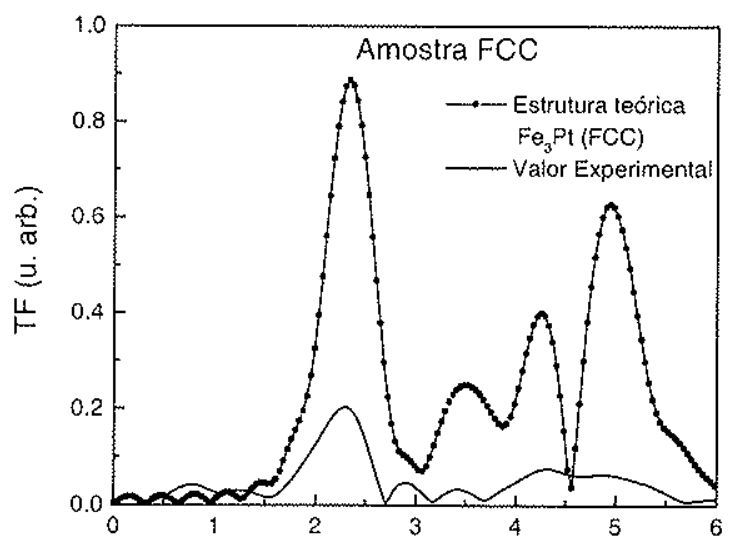

a)

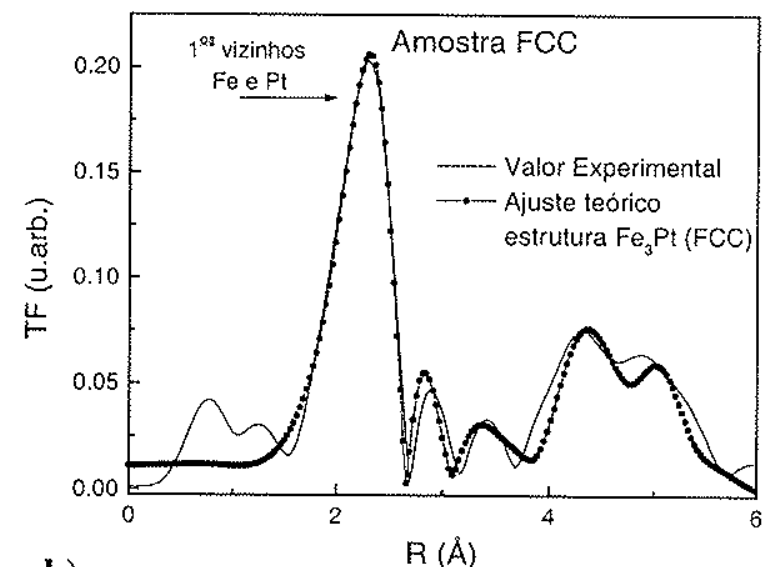

b)

Fig. 5.31 - (a) TF do espectro experimental de EXAFS da amostra FCC (obtido na configuração $\theta$ $=36^{\circ}$ ) sobreposto à TF obtida através de uma simulação para uma estrutura teórica $\mathrm{Fe}_{3} \mathrm{Pt}(\mathrm{FCC})$. (b) $\mathrm{TF}$ da estrutura $\mathrm{Fe}_{3} \mathrm{Pt}$ ajustada ao valor experimental da amostra FCC. 
A aleatoriedade nas posições dos átomos de Fe e Pt em uma estrutura FePt FCC, tornou difícil modelar uma estrutura teórica sobre o qual pudesse ser gerada a simulação de um espectro de EXAFS. Como uma alternativa inicial, adotamos o procedimento de gerar simulações teóricas para estruturas de FePt ricas em $\mathrm{Fe}$ ou $\mathrm{Pt}$, verificando os resultados obtidos. Na Figura 5.31(a) é apresentada a transformada de Fourier (TF) do espectro experimental de EXAFS da amostra FCC sobreposta à TF obtida através de uma simulação para uma estrutura teórica $\mathrm{Fe}_{3} \mathrm{Pt}$ (FCC). Variando-se alguns parâmetros como o fator de redução da amplitude $\left(S_{0}{ }^{2}\right)$ e o fator de Debye-Waller $(\sigma)$, procuramos ajustar a TF da estrutura teórica ao dado experimental obtido para a amostra FCC. Os ajustes foram realizados com o auxílio do programa Feffit [44-46]. Na Figura 5.31(b), é apresentado TF da amostra FCC com o respectivo ajuste teórico obtido. Para este ajuste teórico foram modificadas as quantidades de átomos de Fe e Pt na estrutura. Isso para simular uma estrutura não estequimétrica, ou seja, mais rica em $\mathrm{Pt}$ que o $\mathrm{Fe}_{3} \mathrm{Pt}$. $\mathrm{O}$ valor de $\mathrm{S}_{0}{ }^{2}$ não foi considerado como sendo fixo. Quanto ao fator de Debye-Waller $(\sigma)$, valores diferentes para cada esfera de coordenação foram considerados. Os parâmetros estruturais obtidos com o ajuste apresentado na Figura 5.31(b) são listados na Tabela 5.10. Pode-se ver que com o ajuste, variando-se os números de ocupação dos átomos de Fe e Pt na estrutura, obtivemos que o filme possui um conteúdo de Fe de $0,62 \%$, menor do que o esperado para uma $\mathrm{Fe}_{3} \mathrm{Pt}$ (FCC) pura. Com a simulação para uma estrutura $\mathrm{FePt}_{3}$, não conseguimos obter um ajuste teórico que refletisse o comportamento da amostra. Comparando as transformadas de Fourier obtidas através de simulações para estruturas teóricas de $\mathrm{Fe}_{3} \mathrm{Pt} \mathrm{e} \mathrm{FePt}_{3}$ (Fig. 5.32),

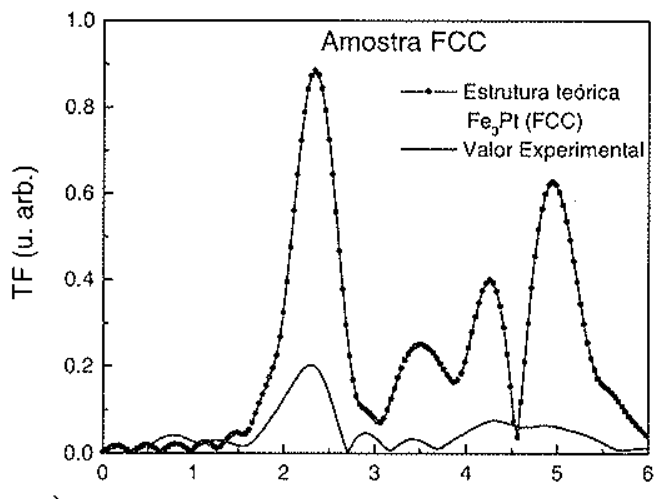

a)

$\mathrm{R}(\AA)$

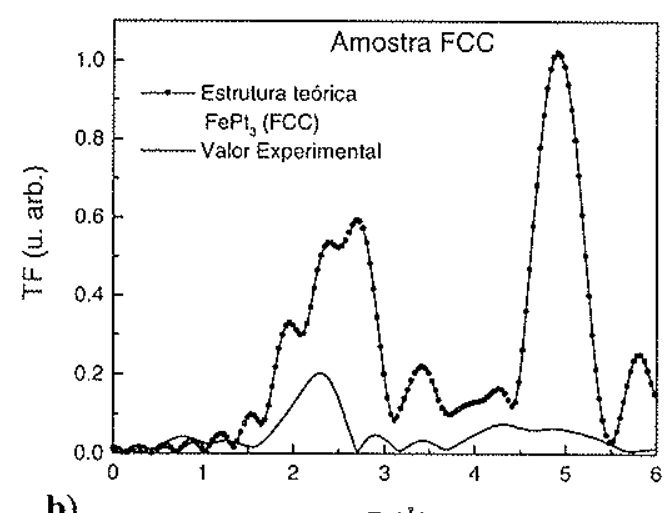

b)

$\mathrm{R}(\AA)$

Fig. 5.32 - (a) TF do espectro experimental de EXAFS da amostra FCC (obtido na configuração $\theta=36^{\circ}$ ) sobreposto à $T F$ obtida através de uma simulação para uma estrutura teórica (a) $\mathrm{Fe}_{3} \mathrm{Pt}$ e (b) $\mathrm{FePt}_{3}$. 


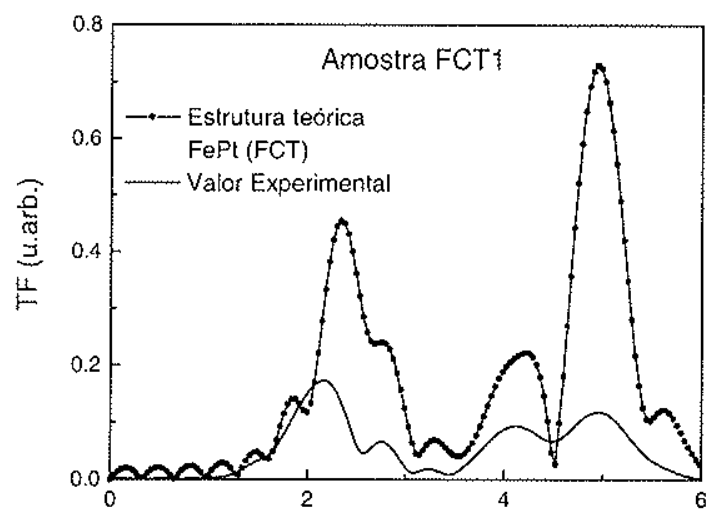

a)

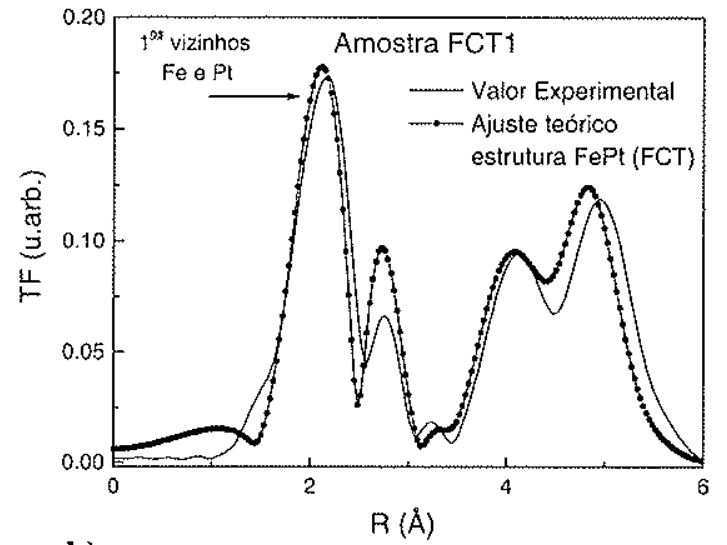

b)

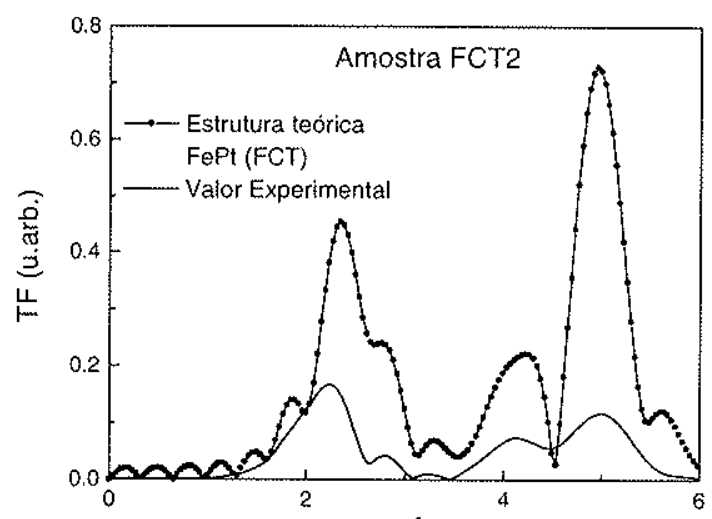

$R(\AA ̊)$

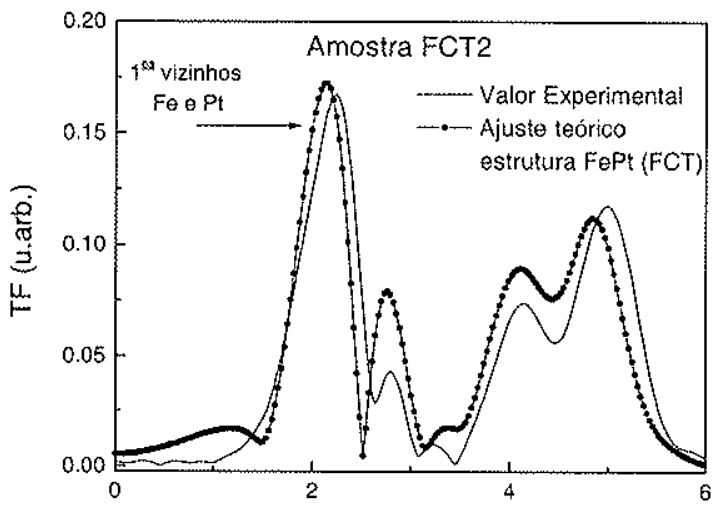

$\mathrm{R}(\AA)$

Fig. 5.33 - (a) TF do espectro experimental de EXAFS das amostras FCT1 e FCT2 (obtido na configuração $\theta=36^{\circ}$ ) sobreposto à TF obtida através de uma simulação para uma estrutura teórica FePt (FCT). (b) TF da estrutura FePt (FCT) ajustada ao valor experimental das amostras FCT1 e FCT2.

podemos verificar que nenhuma correlação existe entre as mesmas. Em outra situação chegamos a simular uma combinação de espectros das duas estruturas ( $\mathrm{Fe}_{3} \mathrm{Pt}$ e $\mathrm{FePt}_{3}$ ), porém verificamos que os resultados obtidos não permitiam um ajuste de boa qualidade. Somente a simulação para uma estrutura rica em Fe se ajustou bem ao dado experimental. Este resultado indica que no filme os átomos de mesma espécie tendem a se aglomerar próximos uns dos outros, provavelmente devido a maior afinidade química.

Na Figura 5.33(a) é apresentada a TF do espectro experimental de EXAFS, das amostras FCT1 e FCT2 (medidos por XAS na configuração $\theta=36^{\circ}$ ), sobreposto à TF obtida através de uma simulação para uma estrutura teórica FePt (FCT). Na Figura 5.33(b), apresentamos a transformada de Fourier da estrutura teórica FePt (FCT) ajustada às transformadas de Fourier experimentais das amostras FCT1 e FCT2. O ajuste foi gerado considerando-se uma estrutura estequiométrica (sem modificação no número de ocupação). 
Tabela 5.10 - Parâmetros estruturais obtidos com os ajustes teóricos de EXAFS da amostra FCC, FCT1 e FCT2.

\begin{tabular}{|c|c|c|c|c|c|c|}
\hline Amostra & $\begin{array}{c}\text { Ocupação } \\
\text { do Fe }\end{array}$ & $\begin{array}{c}\text { Ocupação } \\
\text { da Pt }\end{array}$ & $\begin{array}{c}\text { Conteúdo } \\
\text { de Fe }\end{array}$ & $S_{0}{ }^{2}$ & \multicolumn{2}{|c|}{$\begin{array}{c}\text { Debye-Waller } \\
(\sigma) \\
\left(\AA^{2}\right)\end{array}$} \\
\hline FCC & 0,72 & 1,32 & 0,62 & 0.91 & 0,004 & 0,012 \\
\hline FCT1 & estequiométrica & estequiométrica & 0,50 & 0.98 & 0,008 & 0,013 \\
\hline FCT2 & estequiométrica & estequiométrica & 0,50 & 0.98 & 0,009 & 0,013 \\
\hline
\end{tabular}

A: $1^{\underline{3}}$ esfera de coordenação.

B: Demais esferas de coordenação.

* Valor considerado fixo durante o ajuste teórico.

Como dados de entrada para o ajuste, foram utilizados um valor fixo de $\mathrm{S}_{0}{ }^{2}$ e valores de $\sigma$ diferentes para cada esfera de coordenação. Os parâmetros estruturais obtidos com o ajuste são listados na Tabela 5.10. É possível verificar que os valores de $\sigma$ obtidos para as amostras FCT1 e FCT2 são muito próximos, indicando que, em termos de desordem estrutural, poucas diferenças existem para as duas amostras. Analisando as Figuras 5.33(b), verificamos, para as duas amostras, que a TF da estrutura teórica não se ajusta perfeitamente à TF do dado experimental. Para as duas amostras, é possível verificar que o ajuste para o pico próximo a $2,0 \AA$ se apresenta um pouco superestimado e deslocado à esquerda. Acreditamos que estas diferenças observadas refletem o fato das duas amostras não possuírem uma camada de FePt completamente ordenada quimicamente, conforme se supôs no modelo teórico. Analisando as transformadas de Fourier dos caminhos de difusão simples $\mathrm{Fe}-\mathrm{Pt}$ e $\mathrm{Fe}-\mathrm{Fe}$ obtidos através da simulação para estrutura teórica FePt FCT, verificamos que este pico em 2,0 Å é correlacionado com primeiros vizinhos tanto de Fe quanto de Pt, o que era de se esperar, pois as distâncias interatômicas das duas espécies em relação ao átomo absorvedor são muito próximas.

De modo geral, os resultados obtidos através das análises de XAS dos filmes de FePt nos mostram que:

- Para os filmes de FePt com fase estrutural FCC(100), os resultados obtidos com as simulações de XANES e EXAFS para uma estrutura teórica $\mathrm{Fe}_{3} \mathrm{Pt} \mathrm{FCC}$ (rica em átomos de $\mathrm{Fe}$ ) mostraram-se satisfatórios. O excesso de ferro detectado por XAS não se contrapõe à análise por RBS, uma vez que a análise de XAS na borda $\mathrm{K}$ do Fe não é sensível a aglomerados de $\mathrm{Pt}$, possivelmente presentes na amostra;

- No caso dos filmes de FePt com a fase FCT(001), as simulações de XANES e EXAFS, para uma estrutura teórica FePt FCT, mostram que esses filmes não são perfeitamente 
ordenados quimicamente, o que está de acordo com as informações obtidas através de análises de XRD. Os resultados obtidos revelam que existe uma parcela de desordem química no filme (troca de $\mathrm{Fe}\{\mathrm{Pt}\}$ por $\mathrm{Pt}\{\mathrm{Fe}\}$ ). Vale lembrar que, para esses filmes de FePt, valores de parâmetro $S$ de aproximadamente 0,84 foram obtidos.

O estudo das propriedades estruturais de filmes de FePt por XAS ainda se encontra em sua fase inicial. Novas simulações de XANES e de EXAFS para estruturas teóricas que representem melhor a aleatoriedade nas posições dos átomos de Fe e Pt em uma estrutura FePt FCC e a parcela de desordem química da estrutura FePt FCT ainda terão que ser desenvolvidas.

Concluída assim a apresentação e a respectiva análise dos resultados experimentais, apresentamos no próximo capítulo as conclusões deste trabalho. 


\section{Capítulo 6}

\section{Conclusões}

Neste capítulo apresentamos as conclusões obtidas através do estudo das propriedades estruturais e magnéticas dos filmes de FePt investigados. 
Com relação a preparação das amostras, dominamos a técnica de produção, o que permitiu a obtenção de filmes de ótima qualidade. Automatizamos o controle dos obturadores do sistema de "sputtering" utilizado. Com isso, pudemos preparar filmes ordenados de FePt também pelo método de deposição alternada de monocamadas atômicas.

Para os filmes produzidos, a análise estrutural se mostrou consistente com a magnética.

Para os filmes de FePt com fase estrutural quimicamente desordenada FCC(100), as simulações de XANES e EXAFS mostraram que a estrutura de ordem local ao redor do átomo absorvedor $(\mathrm{Fe})$ possui uma maior quantidade de ligações $\mathrm{Fe}-\mathrm{Fe}$ como primeiros vizinhos do que Fe-Pt. Este resultado indica que no filme, átomos de mesma espécie tendem a se aglomerar próximos uns dos outros. No caso dos filmes de FePt com a fase ordenada FCT(001), as simulações de XANES e EXAFS, para uma estrutura teórica FePt FCT, mostram que essas amostras não são perfeitamente ordenadas, contendo uma pequena parcela de desordem química no filme, o que é consistente com as informações obtidas através de análises de XRD.

\subsection{Filmes de FePt preparados por Codeposição}

Para filmes de FePt, com composições estequiométricas de $\sim 50 \%$ de Fe, preparados através do método de deposição simultânea (codeposição) de elementos de Fe e Pt, com o auxílio da técnica de "Sputtering Magnetron DC", obtivemos os seguintes resultados:

a) $\mathrm{O}$ uso de substratos amorfos $\mathrm{SiO}_{2}$ e monocristalinos de $\mathrm{Si}(100)$, com e sem o "buffer" de Pt, não são adequados para induzir somente uma desejada fase FCT(001) em uma camada de FePt, mesmo com deposições em altas temperaturas do substrato. No caso específico dos substratos de $\mathrm{Si}(100)$, a obtenção de efeitos de um crescimento "epitaxial" induzido não tornou-se possível devido a incompatibilidade estrutural existente entre a liga FePt e o substrato;

b) Com a utilização de substratos monocristalinos de $\mathrm{MgO}(100)$, obteve-se bons resultados de uma "epitaxia" conveniente para o ordenamento da estrutura cristalina desses filmes. Os efeitos de um crescimento induzido da estrutura cristalina FCT, com textura predominante [001], alto grau de ordenamento 
químico $(S=0,84)$ e respectivas propriedades magnéticas (anisotropia magnética perpendicular e alta coercividade), foi possível com deposições em $\mathrm{T}_{\mathrm{S}}=600^{\circ} \mathrm{C}$. Com a utilização de uma camada "buffer" de Pt, pré-depositada sobre substratos de $\mathrm{MgO}$, obteve-se melhores condições para um crescimento "epitaxial" induzido da camada FePt com a fase FCT(001). Os resultados mostraram que as propriedades estruturais e magnéticas da camada FePt são fortemente dependentes das condições iniciais de preparação do respectivo "buffer" (temperatura do substrato e espessura). O uso do "buffer" de Pt otimizado (estrutura FCC e textura dominante [100]), tornou possível produzir filmes de FePt com a fase FCT(001) e valor de $S=0,46$, em deposições realizadas em $\mathrm{T}_{S}(\mathrm{Pt} / \mathrm{FePt})=300 / 300^{\circ} \mathrm{C}$, e alto grau de ordenamento $(S=0,80)$ em $\mathrm{T}_{S}(\mathrm{Pt} / \mathrm{FePt})=500 / 500^{\circ} \mathrm{C}$. A obtenção da fase $\mathrm{FCT}(001)$ em temperaturas reduzidas se deve a boa combinação entre os parâmetros de rede da camada FePt e do "buffer".

\subsection{Filmes de FePt preparados por DAM}

Com relação a preparação de filmes de FePt através do método experimental de deposição alternada de monocamadas atômicas (DAM) de Fe e Pt, utilizando a técnica de "Sputtering Magnetron DC", obtivemos os seguintes resultados:

a) Filmes depositados diretamente sobre o substratos de $\mathrm{MgO}$ apresentaram a formação da fase estrutural $\mathrm{FCT}(001)$ a partir de $\mathrm{T}_{\mathrm{S}}=200^{\circ} \mathrm{C}$ e a presença de um bom grau de ordenamento químico $(S=0,32)$ em $\mathrm{T}_{\mathrm{S}}=400^{\circ} \mathrm{C}$;

b) Para filmes crescidos sobre substratos de $\mathrm{MgO}$ com uma camada "buffer" de Pt, em condições onde o "buffer" e a camada FePt foram depositados em mesma $\mathrm{T}_{S}$, a presença da fase FCT $(001)$ é observada em $\mathrm{T}_{S} \geq 300^{\circ} \mathrm{C}$. Para condições onde o "buffer" de Pt foi pré-depositado em alta $\mathrm{T}_{S}\left(500^{\circ} \mathrm{C}\right)$, a formação da fase $\mathrm{FCT}(001)$ é observada a partir de $\mathrm{T}_{\mathrm{S}}=200^{\circ} \mathrm{C}$, com um alto grau de ordenamento químico $(S=0,88)$ em $\mathrm{T}_{\mathrm{S}}=400^{\circ} \mathrm{C}$.

Os resultados alcançados mostram que, em termos da obtenção de um filme de FePt com a fase FCT(001) e alto grau de ordenamento químico, com deposições em reduzido valor de $\mathrm{T}_{\mathrm{S}}$, o método de DAM é mais eficaz do que o método de codeposição. 
Finalmente, gostaríamos de mencionar que apesar deste tema ter nos colocado em competição direta com centros de pesquisa de grandes empresas, os bons resultados obtidos propiciaram a publicação de 03 artigos. Atualmente estamos concluindo a redação de um quarto e outros 02 ainda serão elaborados. 


\section{Capítulo 7}

\section{Sugestões para Trabalhos Futuros}

Apresentamos neste capítulo algumas recomendações para trabalhos futuros envolvendo o estudo desses materiais. 
Como sugestões para trabalhos futuros temos:

1. Preparação de filmes de FePt sobre outros tipos de materiais possíveis de serem utilizados como um "buffer" (Ag, Pd, etc..), ou uma "underlayer" (CrMo, $\mathrm{CrV}$, etc.);

2. Como o potencial de aplicação tecnológica desta classe de materiais está, também, diretamente ligado à sua utilização como mídia de gravação magnetoóptica, seria importante a realização de estudos de dependência espectral da sua resposta magnetoóptica em vários comprimentos de onda;

3. Estudar os efeitos produzidos em filmes de FePt, com diferentes fases estruturais, quando submetidos a processos de implantação iônica;

4. Realizar análises de Microscopia de Força Magnética (MFM). Com este estudo seria possível verificar como é a configuração dos domínios magnéticos em filmes de FePt com diferentes anisotropias magnéticas;

5. Estudos sobre a anisotropia magnética efetiva de filmes de FePt com diferentes fases estruturais através da técnica de Ressonância Ferromagnética. Por essa técnica é possível uma avaliação da homogeneidade magnética das amostras e a investigação das contribuições de superfície e volume para a anisotropia magnética efetiva. 


\section{Apêndice I}

\section{Fichas JCPDS}

Neste apêndice, são apresentadas as fichas JCPDS para a liga FePt com estrutura FCC e FCT, para os elementos Platina e Silício e para o MgO. 


\section{FePt - estrutura FCC}

\section{Ficha JCPDS}

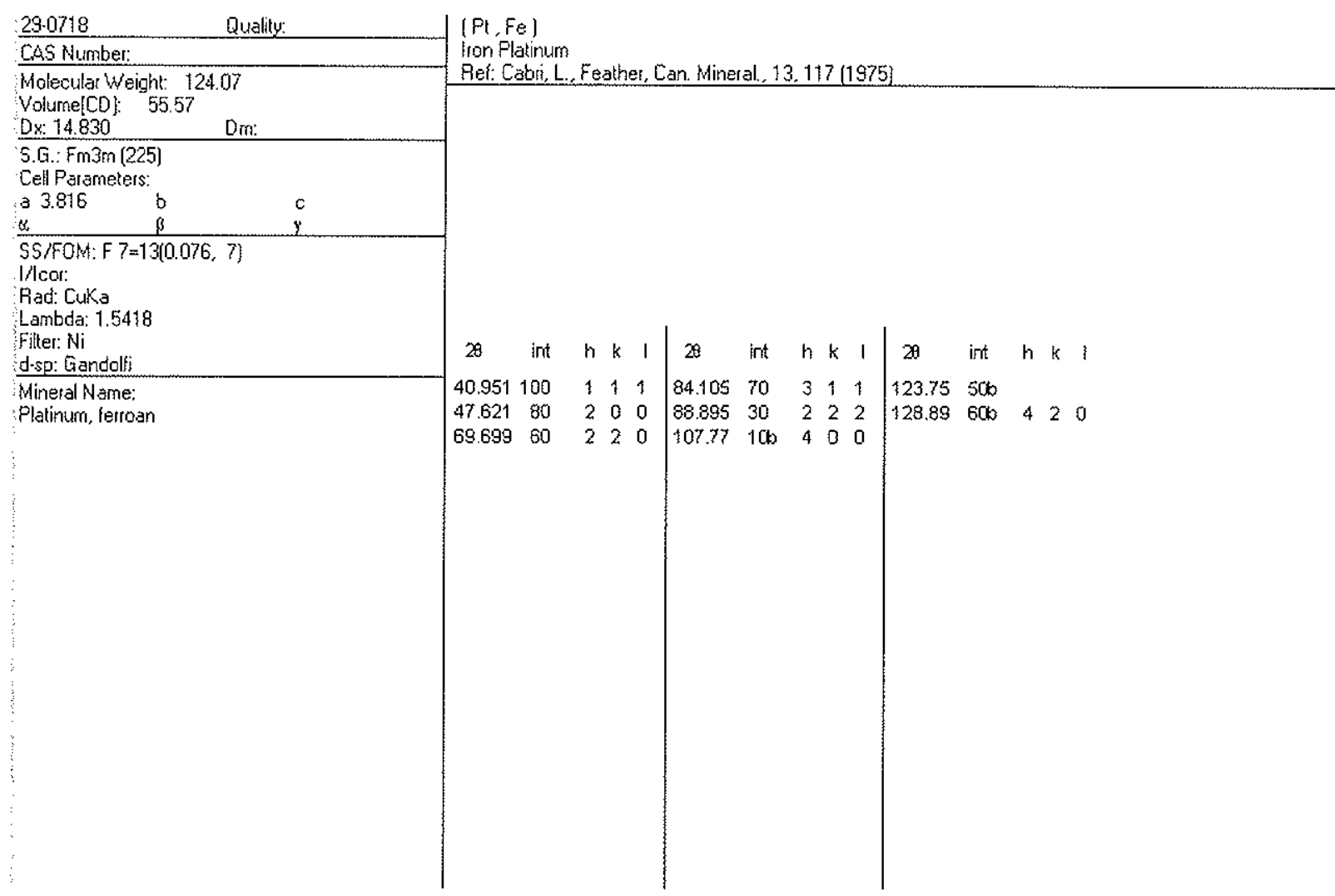




\section{FePt - estrutura FCT}

Ficha JCPDS

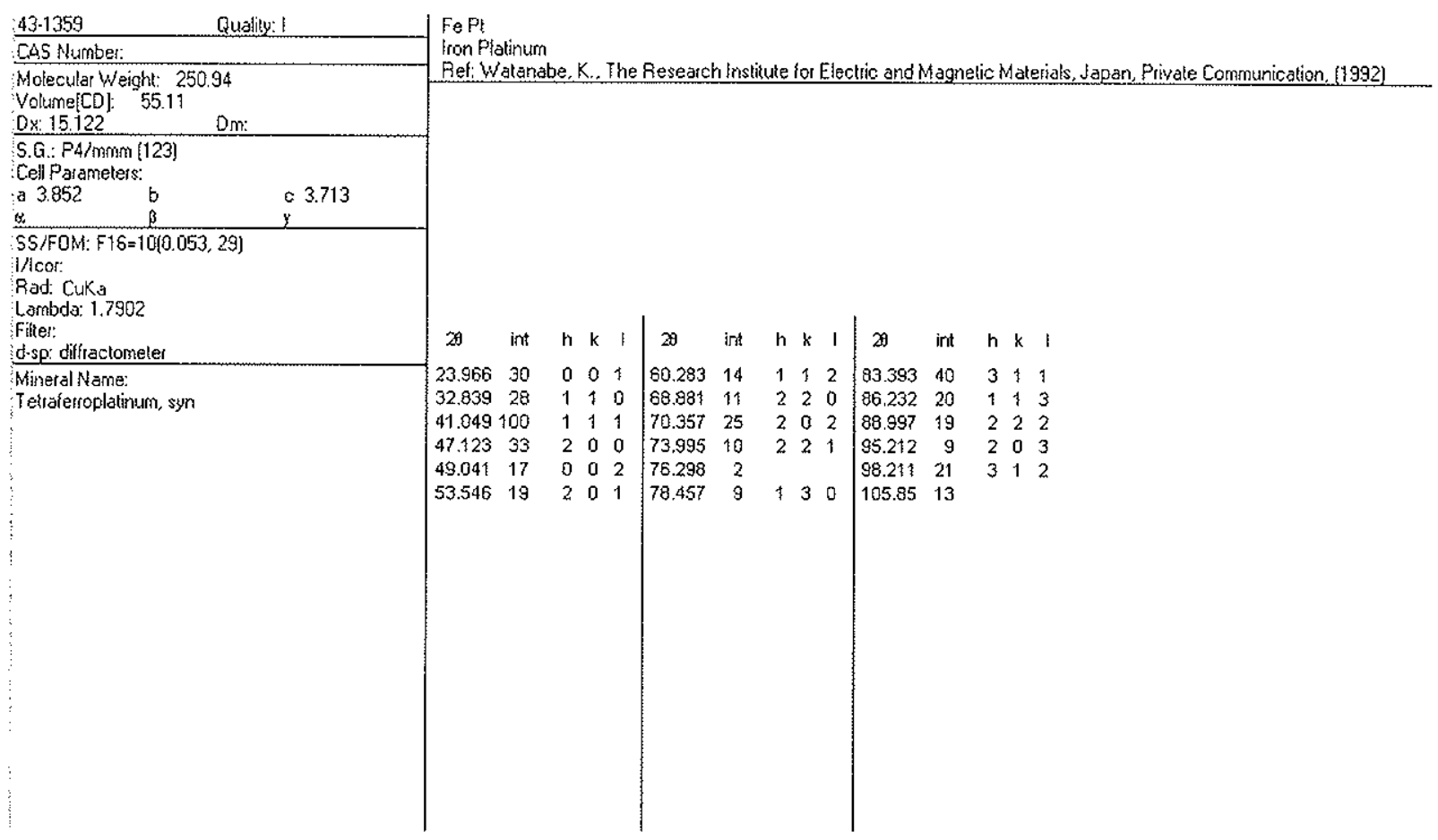




\section{Platina}

\section{Ficha JCPDS}

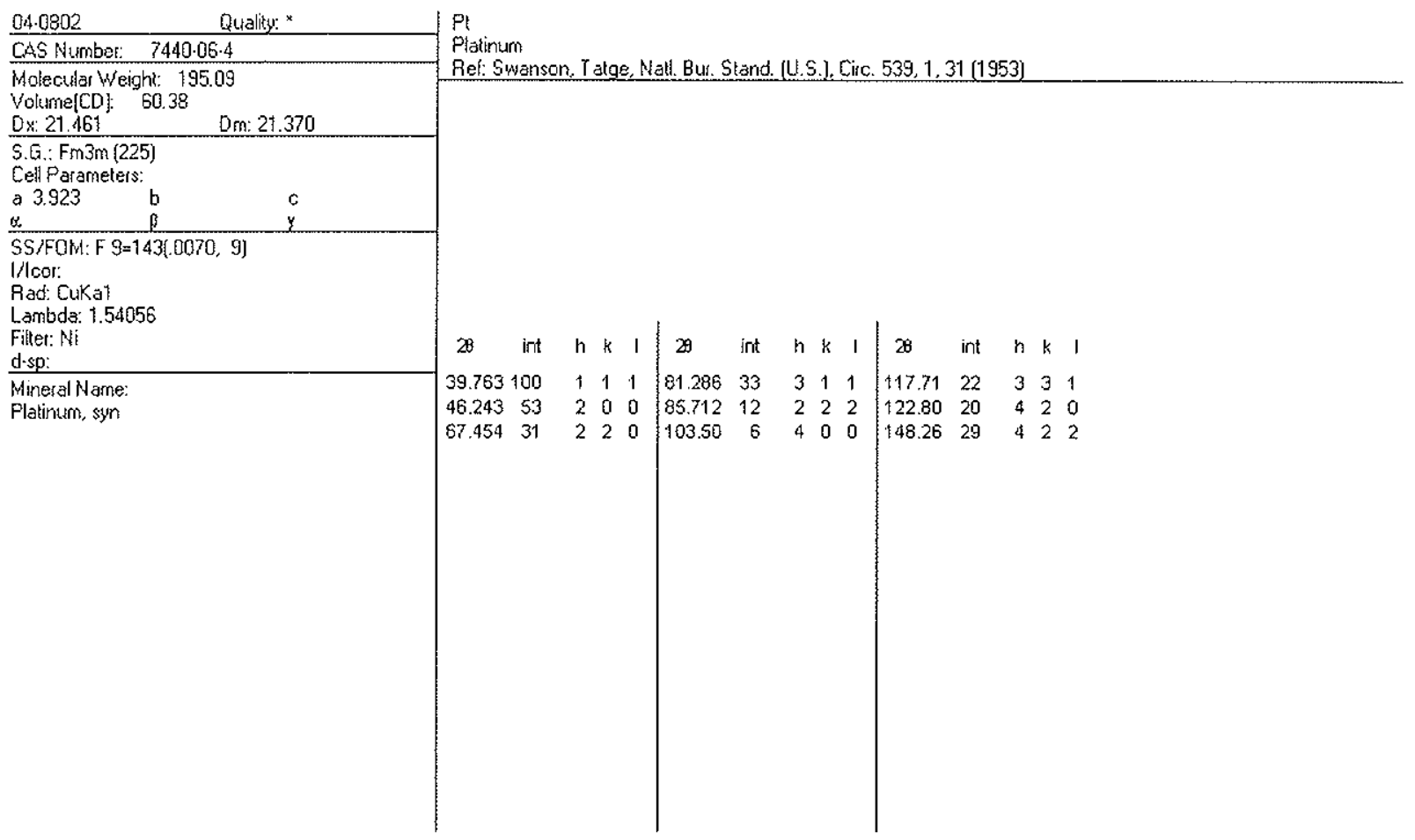




\section{Silício}

\section{Ficha JCPDS}

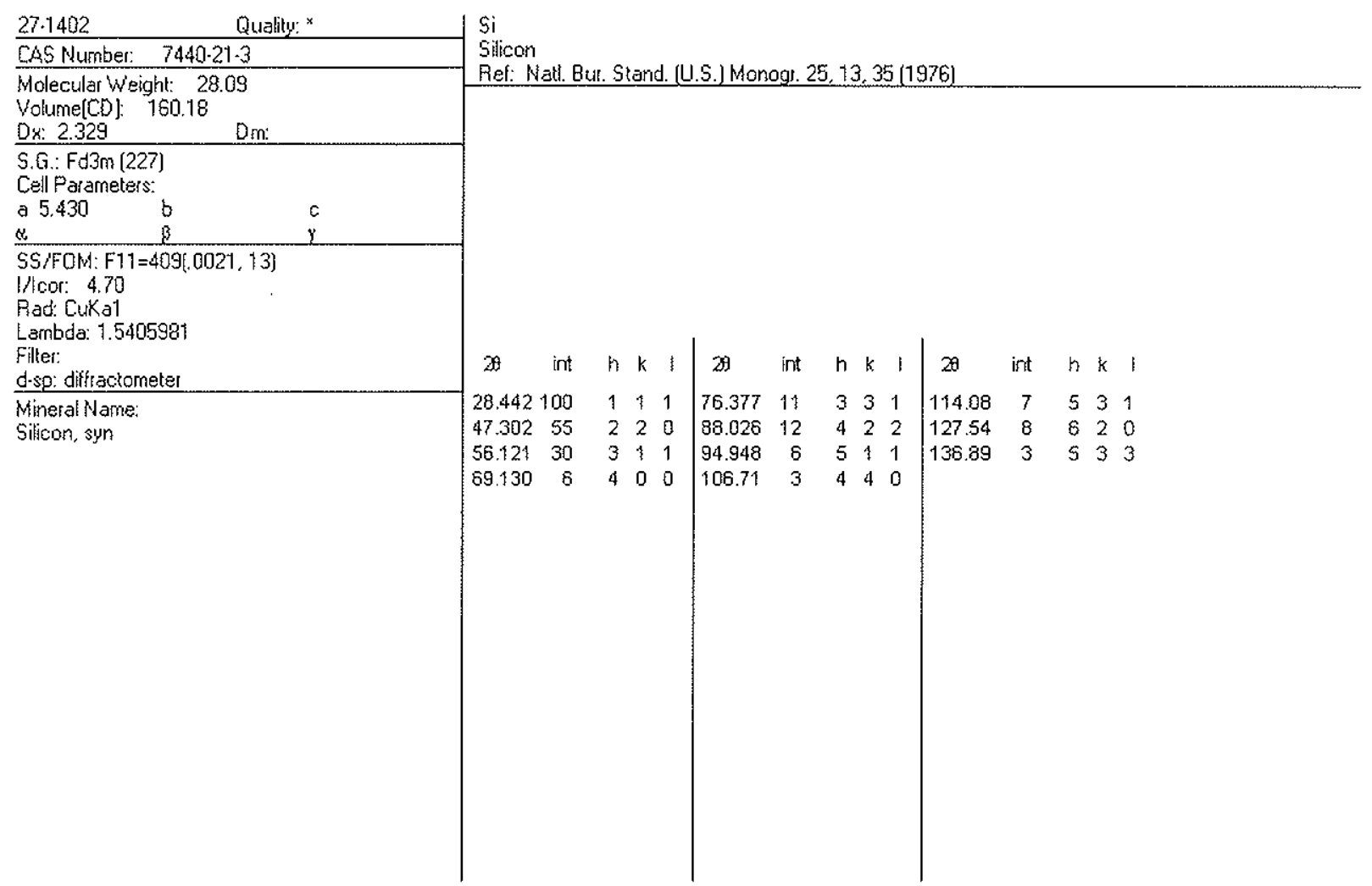




\section{MgO}

\section{Ficha JCPDS}

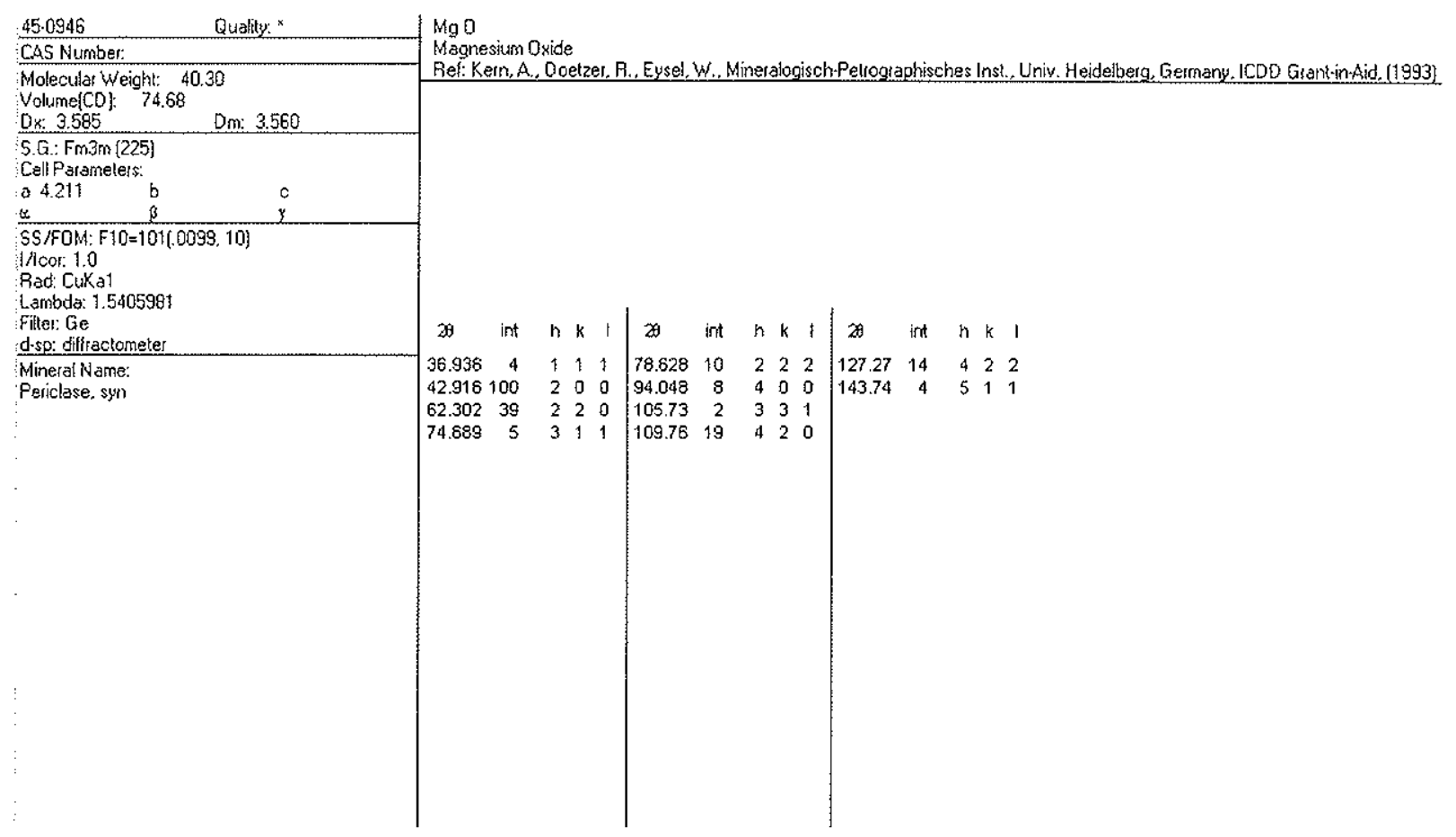




\section{Apêndice II}

\section{Publicações em Periódicos}

Neste apêndice, são apresentados os artigos publicados. São incluídos os que foram publicados, aceitos e submetidos. 
1. A. Martins, M. C. A. Fantini and A. D. Santos, "Structural and magnetic study of FePt thin films as a function of the deposition temperature", Phys. Stat. Sol. (A), 187, 189 (2001),

2. A. Martins, M. C. A. Fantini and A. D. Santos, "The influence of the deposition temperature and substrate on the properties of FePt thin films", J. Mag. Mag. Mater., $265,13-22(2003)$.

3. A. Martins, M. C. A. Fantini, and A. D. Santos, "Growth of L10 ordered FePt alloy films at reduced temperatures" Phys. Stat. Sol. (A), 201, 837 (2004).

4. A. Martins, M. C. A. Fantini, M. H. Tabacniks and A. D. Santos, "Alternate monoatomic layer sputter deposition of fct ( $\mathrm{L}_{0^{-}}$-type) ordered FePt films", J. Magn. Magn. Mater. (2003). Submetido. 


\section{Apêndice III}

\section{Trabalhos apresentados em eventos}

Neste apêndice, são apresentados os trabalhos resultantes da presente tese que foram apresentados em conferências, "workshops", etc. 
1. A. Martins, M. C. A. Fantini, A. D. Santos. "Structural and Magnetic Study of FePt Thin Films as a Function of the Deposition Temperature". 3TH BRAZILIAN/GERMAN WORKSHOP ON APPLIED SURFACE SCIENCE, Itapema - SC. (2001).

2. A. Martins, M. C. A. Fantini, A. D. Santos. "Estudo Estrutural e Magnético de Filmes Finos de FePt como uma Função de Temperatura de Deposição. XXIV ENCONTRO NACIONAL DE FÍSICA DA MATÉRIA CONDENSADA, São Lourenço - MG. (2001).

3. A. Martins, M. C. A. Fantini, A. D. Santos. "Caracterização Estrutural e Magnética de Filmes Finos de FePt". III ESCOLA BRASILEIRA DE MAGNETISMO JORGE ANDRÉ SWIECA, Porto Alegre - RS. (2001).

4. A. Martins, M. C. A. Fantini, A. D. Santos. "Influência da Temperatura de Deposição e do Tipo de Substrato na Obtenção das Propriedades Estruturais e Magnéticas de Filmes de FePt". XXV ENCONTRO NACIONAL DE FÍSICA DA MATÉRIA CONDENSADA, Caxambú MG. (2002).

5. A. Martins, M. C. A. Fantini, A. D. Santos. "Production and Characterization of FePt Films for Perpendicular Magnetic Recording". $2^{\text {a }}$ REUNIÃO ANUAL DA RENAMI - REDE DE NANOTECNOLOGIA MOLECULAR E DE INTERFACES, Búzios...RJ. (2003).

6. A. Martins, M. C. A. Fantini, A. D. Santos. "Métodos de Preparação de Filmes de FePt com Anisotropia Magnética Perpendicular". XXVI ENCONTRO NACIONAL DE FÍSICA DA MATÉRIA CONDENSADA, Caxambú-MG. (2003).

7. A. Martins, M. C. A. Fantini, A. D. Santos. "Growth of L1o Ordered FePt Alloy Films at Reduced Temperatures". 4TH GERMAN/BRAZILIAN WORKSHOP ON APPLIED SURFACE SCIENCE, Ringberd-Castle, Tegernsee (Alemanha). (2003).

8. A. Martins, M. C. A. Fantini, R. J. Prado, N. M. S. Neto, A. Y. Ramos and A. D. Santos. "Determinação da Estrutura local de filmes de FePt por EXAFS". XIV REUNIÃO ANUAL DE USUÁRIOS DO LNLS, Campinas-SP. (2004). 


\section{Referências Bibliográficas}

[1] J. D. Livingston, Scientific American, p.80-85, Novembro (1998).

[2] G. Bate, J. Mag. Magn. Mat., 100, p.413-424, (1991).

[3] J. W. Toigo, Scientific American, p.1-6, Maio (2000).

[4] http://www.consumerdvreviews.com/news/1101/11092001_02.asp

[5] M. Knobel, Ciência Hoje, vol. 27, n. 159, p. 32-38, Abril (2000).

[6] I. C. Oppenheim, "Gravação Magnética Digital", In: I Escola Brasileira de Magnetismo, IFUSP-São Paulo, p. 20.1-20.5 (1998)

[7] A. B. Marchant, "Otical Recording: A technical overview", Ed. Addison-Wesley Publishing Co, New York, (1990).

[8] T. D. Milster, "Near-Field Optics: "A New Tool for Data Storage", Proceedings of the IEEE, vol. 88, No. 9, p. 1480, Setembro (2000).

[9] T. Osterloh, P. M. Oppeneer, J. Sticht e J. Kübler, J. Phys.: Condens. Matter, 6, p.285, (1994).

[10] T. Katayama, T. Sugimoto, Y. Suzuki, M. Hashimoto, P. de Haan et al. J. Mag. Magn. Mat., p.104-107 (1992).

[11] A. Cebollada, D. Weller, J. Sticht, G. R. Harp, R. F. C. Farrow, R. F. Marks, R. Savoy, e J. C. Scott, Phys, Rev. B , 50 (5), p.3419, (1994).

[12] J. P. Hu e P. Lin, IEEE Trans. on Magn., MAG-32, p. 4096, (1996).

[13] M. Ohring, "The Materials Science of Thin Films", Academic Press, New York, (1992).

[14] J. A. Bland, e B. Heinrich.. "Ultrathin Magnetic Structures" V. I, II, Springer Verlag, Heidelberg, (1994).

[15] B. D. Cullity, "Elements of X-ray Diffraction", $2^{\mathrm{a}}$ Edição, Addison-Wesley, Reading, Massachussets, (1978).

[16] D. J. Craik, "Magnetism: Principles and Applications", John Wiley \& Sons, New York, (1995).

[17] B. D. Cullity, "Introduction to Magnetic Materials", Addison-Wesley, Reading, Massachussets, (1972).

[18] M. Knobel, Rev. Bras. de Ens. de Fúsica, v.22, n.3, p. 387, Setembro (2000).

[19] T. Suzuki, K. Harada, N. Honda e K. Ouchi, J. Mag. Magn. Mat., 193, p.85 (1999). 
[20] R. A. Ristau, K. Barmak, L. H. Lewis, K. R. Coffey e J. K. Howard, J. Appl. Phys., 86 (8), p. 4527, (1999).

[21] J. Yu, U. Ruediger, A. D. Kent, R. F. C. Farrow, R. F. Marks, D. Weller, L. Folks, e S. S. P. Parkin, J. Appl. Phys., 87(9), p.6854, (2000).

[22] S. W. Yung, Y. H. Chang, T. J. Lin e M. P. Hung, J. Magn. Magn. Mater. 116, p.411, (1992).

[23] R. F. Farrow, D. Weller, R. F. Marks, M. F. Toney, D. J. Smith, M. R. MacCartney, J. Appl. Phys. 84, p. 934 (1998).

[24] J. U. Thiele,L. Folks, M. F. Toney, e D. K.Weller, J. Appl. Phys. 84, p.5686, (1998).

[25] H. Zeng, M. L. Yan, N. Powers, e D. J. Sellmyer, J. Magn. Magn. Mater. 116, p.411, (1992).

[26] T. Saito, O. Kitakami, e Y. Shimada, J. Magn. Magn. Mater. 239, p.310, (2002).

[27] D. Ravelosona, C. Chappert, e V. Mathet, J. Appl. Phys. 87, p. 5771, (2000).

[28] M. -G. KIM, e S. C. SHIN, J. Appl. Phys. 90, p.2211, (2001).

[29] Y. Xu, J. S. Chen e J. P. Wang, Appl. Phys. Lett. 80, p. 3325, (2002).

[30] T. Maeda, T. Kai, A. Kikitsu, T. Nagase, e J. Akiyama, Appl. Phys. Lett. 80, p.2147, (2002).

[31] T. Shima, T. Moriguchi, S. Mitani, e K. Takanashi, Appl. Phys. Lett. 80, p.288 (2002).

[32] F. M. Rhen, G. Hinds, C. O'Reilly, e J. M. D. Coey, , IEEE Trans. on Magn. 39, n.5, p. $2699,(2003)$.

[33] H. Zeng, S. Sun, et al, Appl. Phys. Lett. 80, p. 2583, (2002).

[34] S. Sun, C. B. Murray, D. Weller, L. Folks e A. Moser, Science, 287, p.1989, (2000).

[35] W. K. Chu, J. W. Mager e M. A. Nicolet. "Backscattering Spectrometry", Academic Press, New York, (1978).

[36] M. H. Tabacniks, "Análise de Filmes Finos por Pixe e RBS", In: I Escola Brasileira de Magnetismo, IFUSP-São Paulo, p. 14.1-14.21 (1998).

[37] L. R. Doolittle, Nucl. Instr. Meth. Phys. Res., B9, p.344, (1985).

[38] M. Mayer, AIP Conference Proceedings, 475(1), p.541, (1999).

[39] M. C. A. Fantini, "Análise Estrutural e Morfológia por Raios-X”, In: I Escola Brasileira de Magnetismo, IFUSP-São Paulo, p. 13.1-13.19, (1998).

[40] B. E. Warren, "X-Ray Diffraction”, Dover, New York, (1990). 
[41] D. C. Koningsberger e R. Prins, "X-Ray Absorption: Principles, Applications, Techniques of EXAFS, SEXAFS and XANES", volume 92 of Chemical Analysis, John Wiley and Sons, (1988).

[42] J. C. Cezar, F.C. Vicentin e H.C.N. Tolentino, Rev. Bras. de Ens. de Física, v.22, n.3, p. 363, Setembro (2000).

[43] G. Margaritondo, "Introduction Synchrotron Radiation", Oxford University Press, 1988.

[44] A. L. Ankudinov, B. Ravel, J. J. Rehr, e S. D. Conradson, Phys. Rev. B 58 (12), 7565 (1998).

[45] J. J. Rehr, R. C. Albers, Rev. Mod. Phys. 72 (3), 621, (2000).

[46] A. L. Ankudinov, C. E. Bouldin, J. J. Rehr, J. Sims e H. Hung, Phys. Rev. B 65, 104, (2002).

[47] B. K. Teo, "Exafs Spectroscopy: Techniques and Applications", Hardcover, (1981).

[48] A. Michalowicz, "EXAFS pour le Mac", Logiciels por la Chimie, Societé Française de Chimie, Paris, p. 102 (1991).

[49] S. Foner, "The Review of Scientific Instruments", 30(7), p. 548-557, (1959).

[50] T. Suzuki, K. Ouchi, IEEE Trans. Magn. 37, p. 1283, (2001).

[51] L. -L. Lee, B. K. Cheong, D. E. Laughlin, e D. N. Lambeth, Appl. Phys. Lett. 67, p.3638, (1995).

[52] P. Caro, A. Cebollada, D. Ravelosona, F. Briones, D. Garcia, M. Vásquez e A. Hernando, J. Appl. Phys. 81, p. 5050, (1997).

[53] D. Ravelosona, C. Chappert, H. Bernas, D. Halley, Y. Samson e A. Marty, J. Appl. Phys. 91, p. 8082, (2002).

[54] K. Takanashi, S. Mitani, M. Sano, H. Fujimori, H. Nakajima e A. Osawa, Appl. Phys. Lett. 67, p. 1016, (1995).

[55] T. Shima, T. Moriguchi, T. Seki, S. Mitani e K. Takanashi, J. Appl. Phys. 93, p. 7238, (2003). 